Casuistry and Early Modern Spanish Literature 


\title{
Foro Hispánico
}

\author{
Editorial board
}

Brigitte Adriaensen (Radboud University Nijmegen, $N L$ )

Sebastiaan Faber (Oberlin College, USA)

Konstantin Mierau (University of Groningen, $N L$ )

Dianna Niebylski (University of Illinois at Chicago, USA)

Alison Ribeiro de Menezes (University of Warwick, $U K$ )

Valeria de los Rios (Pontificia Universidad Católica de Chile, CL)

VOLUME 66

The titles published in this series are listed at brill.com/foro 


\title{
Casuistry and Early Modern Spanish Literature
}

\author{
Edited by \\ Marlen Bidwell-Steiner \\ Michael Scham
}

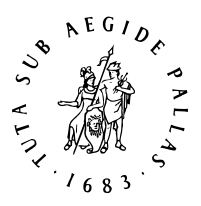

B R I L L

LEIDEN | BOSTON 
This is an open access title distributed under the terms of the CC BY-NC 4.0 license, which permits any non-commercial use, distribution, and reproduction in any medium, provided the original author(s) and source are credited. Further information and the complete license text can be found at https://creativecommons.org/licenses/by-nc/4.o/

The terms of the cc license apply only to the original material. The use of material from other sources (indicated by a reference) such as diagrams, illustrations, photos and text samples may require further permission from the respective copyright holder.

\section{FШF}

Der Wissenschaftsfonds.

The editors would like to thank the Austrian Science Fund (FWF) for sponsoring this Open Access publication.

Cover illustration: "Soul searching" by Gabi Damm, photo-reproduction by Kati Bruder.

The Library of Congress Cataloging-in-Publication Data is available online at https://catalog.loc.gov LC record available at https://lccn.loc.gov/2021062597

Typeface for the Latin, Greek, and Cyrillic scripts: "Brill”. See and download: brill.com/brill-typeface.

ISSN 0925-8620

ISBN 978-90-04-50681-7 (hardback)

ISBN 978-90-04-50682-4 (e-book)

Copyright 2022 by Marlen Bidwell-Steiner and Michael Scham. Published by Koninklijke Brill NV, Leiden, The Netherlands.

Koninklijke Brill NV incorporates the imprints Brill, Brill Nijhoff, Brill Hotei, Brill Schöningh, Brill Fink, Brill mentis, Vandenhoeck \& Ruprecht, Böhlau Verlag and V\&R Unipress.

Koninklijke Brill NV reserves the right to protect this publication against unauthorized use.

This book is printed on acid-free paper and produced in a sustainable manner. 


\section{Contents}

Casuistry and Early Modern Spanish Literature: A Neglected Relationship 1

Marlen Bidwell-Steiner and Michael Scham

Justice, Blindfolded: Law and Crime in the Celestina 17 Marlen Bidwell-Steiner

Artful Rhetoric: The Case of Lázaro de Tormes Edward H. Friedman

The Intrusion of an Apocryphal Guzmán as a (Legal, Moral and Literary) 'Case' in Mateo Alemán's Authentic Second Part 56 David Alvarez Roblin

Theological Casuistry and Casuistical Preposterousness: The Fallacious Cases of La pícaraJustina 75

David Mañero Lozano

The Exploration of Circumstance: Casuistry and the Emergence of the Novela Bizantina in Alonso Núñez de Reinoso's Historia de los amores de Clareo y Florisea, y de los trabajos de Ysea (1552) 93 Anita Traninger

Comic Casuistry and Common Sense: Sancho Panza's Governorship 114 Michael Scham

The Lawyers' Tales: Legal Casuistry and the Spanish Golden Age Novella (Cristóbal Suárez de Figueroa, Alonso de Castillo Solórzano) 135 Mechthild Albert

Opinion, Idolatry, and Indigenous Consciousness: Bartolomé de las Casas' Approach to Human Sacrifice 156 José Cárdenas Bunsen 
Staging Penance: Scenes of Sacramental Confession in Early Modern Spanish Drama 176

Hilaire Kallendorf

Index 203 


\title{
Casuistry and Early Modern Spanish Literature: A Neglected Relationship
}

\author{
Marlen Bidwell-Steiner and Michael Scham
}

The title of this volume has an unspectacular, perhaps even ingenuous ring. And yet, it addresses complex relationships that were fertile with the production of cultural meaning. Early modern Spanish narrative encompasses an amazing variety of highly innovative literary forms. Labelling Don Quijote as the first modern novel has become a commonplace. Yet this is not the only original "Spanish" discourse. Although seemingly exclusively embedded in everyday life (and misery) of 16 th and 17 th century Spanish society, the genre of the picaresque immediately sweeps across Europe. Another case in point is the Spanish comedia as a hybrid dramatic form that transgresses Aristotelian norms for the sake of a changing public taste and need, as Lope de Vega elaborates in his Arte nuevo in 16og. And even well-established genres like the Italian novella become thoroughly refashioned to reemerge in bespoke Spanish clothes. As is to be expected, the attempts to elucidate the extraordinary dynamics of literary and artistic cultures in the Siglo de Oro are myriad. One widely accepted hypothesis argues for the emergence of a specific "modern" subjectivity: a characteristic habitus that permitted reflection upon the tensions that were inherent to a society exposed to the ideologies of the Counter-Reformation, colonialist nation building and the fraught heritage of the three monotheistic cultures (Gumbrecht).

This is the period in which casuistry as a religious, legal, medical and literary practice gains momentum. Although its origins are conventionally associated with medieval penitential books and the practice of applying verdicts pronounced by church authorities in judging the severity of sins during confession, casuistry also has deep roots in legal and medical traditions, including Judaic and Islamic law and theology. Under the terms of the printing revolution, changing knowledge cultures spawn a sophisticated mingling of these threefold origins of casuistry.

The spread of casuistry in early modern Spain is vast, from the strict sense of resolving penitents' "cases of conscience" to broader political, economic, legal and scientific issues. Yet, perhaps owing to its image as a sophistical justification of suspect behavior and political expediency - a perception promoted by the Jansenist Pascal's famous denunciation of Jesuit "laxism" in his Lettres 
provinciales (1657) -, Spanish casuistry has been understudied. Building on the recent attention to casuistry and theatre, this volume explores the interrelation between casuistry and different literary genres in Spain, such as the picaresque, the novella, novela sentimental, and the crónicas. The Querelle des Femmes tradition in late medieval sentimental novels, the casuistical debates of which would blossom in following centuries, allows us to bring out important considerations of gender in the literary works as well as in the culture more generally. As with Spanish theater, the novella develops around dilemmas relating to love and honor; and the flourishing of both literary forms coincides with crucial developments in moral philosophy.

Currently, a revival of casuistry is underway in international scholarship, a notable example being A Historical Approach to Casuistry (edited in 2019 by Carlo Ginzburg with Lucio Biasiori). With its connections to fundamental aspects of rhetoric and epistemological inquiry in various fields, the heritage of casuistry for what becomes labelled the Scientific Revolution is being given its due attention. But a systematic analysis of the impact of casuistical rhetoric on the emergence of highly successful and genuinely Spanish literary genres still is missing. This is all the more regrettable given Spain's distinct situation, which made it a breeding ground for early modern casuistry. To better understand casuistry's specific impact in Spain we briefly want to dwell on this development.

As Jonsen and Toulmin show in their most valuable study, Roman law had its own complicated trajectory from the College of Pontiffs to the Emperor Constantine (55), where jurisdiction became more legal than arbitral. One crucial figure in this heritage is the Roman lawyer, orator and philosopher Cicero, who "borrowed his cases [...] particularly from the literature of Stoicism and of its critics" (76). The Stoics coined the concept of "natural law," which Cicero refashioned under the precepts of Aristotelian Ethics.

For the context of this volume, it is important to point to Cicero's status as role model in early modern humanism. In the Italian Renaissance, Cicero virtually became christianized (especially through Petrarch) and his rhetorical and (to a lesser extent) his ethical writings were a must for the studia humanitatis. Rhetoric and moral philosophy thereby saw a revaluation in the curricula of the newly self-regulated universities in the mold of the one in Bologna. In this process rhetoric became the key discipline in resolving problems not belonging to the strictly theoretical realm of universal validity (i.e., mathematical 
logic). Thus, the particulars of natural law could be approached with Aristotle's enthymeme - an incomplete syllogism or reasoning by analogy. And all the more so with practical problems like ethics. The affinity between Aristotle's reasoning devices in his Rhetorics and his Topics already points to an elaborate casuistry, with the latter resembling the "Jesuit hexameter" (see below). It therefore provided an important model not only for Cicero but also for the Doctors of the Church, Augustine and Aquinas, two central figures for the Dominican friars. Founded by a Spaniard, this Order was especially involved in preaching and teaching. Dominicans also provided the most famous theologians at the University of Salamanca, who were the first to elaborate casuistry stricto sensu, as will be shown.

It is worth noting that in the ranks of Dominicans (as later also the Jesuits) there were many conversos. Some of them most certainly were acquainted with Halakhah, in the words of Jonsen and Toulmin "the casuistry of Rabbinic Judaism" (57). Sophisticated elaborations of Christian maxims certainly benefited from this cultural heritage. In terms of the development of imaginative literature, the Hebrew tradition might even be considered as more formative, as it focused on future cases and not - as the Christian tradition - on past ones. The pluralization of society and the change into an ever more scriptural culture entailed an increasing requirement to display all kinds of concrete everydaylife problems in clear argumentation. In Spain the distinct Catholic readjustment of society became crucial even prior to the Counter-Reformation, since it formed the core of the proto-national program of the Reconquista. Already in the 13th and 14th centuries the so-called (and highly disputed) convivencia came to its limits. With the expulsion of the Jews in 1492 and the accompanying mass conversions, the phenomenon of informing, or "snitching," on the one hand, and self-containment on the other hand led to an atmosphere of increasing social control. In such a situation, internalization and subjectivity are paramount (in this context, see Bidwell-Steiner, in this volume).

\section{Penitential Settings as Schools of Subjectivity}

This "inward turn" (a notion coined by Kahler) was fostered by the practice of penitence, which flourished in Catholic countries after the IV Lateran Council (1215) enacted yearly confessions on pain of excommunication. Friars urged the people to take advantage of this private sacramental talk with their confessor more often; later the Jesuits would excel in doing so (Maryks 2008: 19 sig.). In this development, penitential books flooded Europe to structure a penitent's narration, since the examination of conscience demanded a detailed depiction 
of every circumstance of sinful behavior following the famous questionnaire quis, quid, ubi, quibus auxiliis, cur, quomodo, quando (who, what, where, by which means, why, how, when), which will later be called the Jesuit hexameter.

Indeed, as will be shown, it was the Jesuits who adopted original approaches to earlier penitential guidelines by their Dominican colleagues to develop casuistry into a genuine discipline. Beside their early ministerial focus, Jesuits tended more and more toward tutoring and soon established the "largest educational system of the early modern world" (Maryks 2008: 4), given that their missionary activities included founding schools overseas. Their educational program combined scholastic premises with humanistic innovations. Thus, the Jesuit Ratio Studiorum was close to the Renaissance studia humanitatis. This included a blending of Ciceronian and Aristotelian rhetoric with an emphasis on controversies about difficult cases.

\section{3} A Short History of Spanish Casuistry

The reach of casuistry in early modern Spain expanded dramatically, from the strict sense of resolving penitents' cases of conscience to broader political, economic, jurisprudential and scientific issues. Casuists became prominent educators, economists and political advisers, and their methods were adopted in numerous fields.

The Dominican thinkers Francisco de Vitoria (c.1483-1546), Domingo de Soto (1494-1560) and Bartolomé de Medina (1527-1581) were key members of the "School of Salamanca," which modernized economic thought and developed international law. Their ethical casuistry would be adopted and further elaborated by Jesuits such as Luis de Molina (1528-1581). In the realm of skepticism in medicine and natural philosophy, Francisco Sánchez (1551-1623) is joined by figures like Gómez Pereira (1500-1558?), who developed a strategy of systematic doubt informed by casuistical heuristics (Bidwell-Steiner 2017). Humanists acknowledged the challenge of epistemological relativism and sought to overcome it by considering multiple perspectives, for example by "arguing in utramque partem (on both sides of the question)" in order "to arrive at what they called approximate knowledge, or probable truth" (Kallendorf 2007: 192). Harald Maihold insits quite rightly on the need of considering fictional transgressions within the contemporaneous discussions of the above-mentioned moralists and their accentuations of specific vices (Maihold $363-365$ ).

The Jesuit involvement in education, politics and economics contributed to the rise of a new notion of the subject. Their casuistry is part of "an important shift that characterized the transition from medieval ethics into a modern 
mentality characterized by a higher degree of subjectivity, responsibility and interiority" (Maryks 2008: 117-18). Put this way, early modern casuistry can be understood as a re-negotiation or even reversal of what Jesús Velasco in his analysis of the Siete Partidas identifies as the dialectics between living and dead voices (Velasco 25-52): while medieval law theorists try to transform the living voice in legal texts in the process of creating a persona authentica, early modern casuists emphasize the singularity of lived experience and, as such, challenge the time-transcending validity of the written text.

Such developments are connected to the emergence of Spain as the paradigmatic proto-nationalist Counter-Reformation, imperial and colonialist state with a complex administrative organization. The administration of the colonies raises all kind of ethical questions that could only be dealt with in terms of casuistical methodologies, bringing conversant principles to new phenomena. The most prominent task here is the disputation about the status of autochthonous peoples, most famously in Francisco de Vitoria's De Indis (1532) and in Bartolomé de Las Casas' Historia de las Indias (1552). The "unsought moral relativism" that resulted from the encounter with the New World (cf. Childers) posed profound challenges to established values and the understanding of notions such as humanity and civilization and its customs (see Cárdenas Bunsen, in this volume).

It was a literary scholar who gave us what is still the most valid in-depth definition for "the casus" - be it moral, juridical or medical: "The special character of the case lies in the fact that it asks the question, but cannot give the answer; that it imposes the duty of judgement upon us, but does not itself contain the judgement - what becomes manifest in it is the act of weighing [Wägen], but not the result of the weighing" (Jolles 350 [191]). In other words: at the core of casuistry is a dilemma, a "tension [...] between norms and exceptions. They need each other; they fuel each other," as Carlo Ginzburg puts it in a recent volume on the outreach of casuistry in different historical fields of knowledge (Ginzburg xii). Casuistry links the contingent, the real and the abstract in a graspable form.

Casuistry at its simplest, e.g. in homily, uses cases as imaginings for an abstract normative principle. As J. Allan Mitchell put it, "Casuistry is a diagnostic technique that enables the practitioner to make sense of new cases and unfamiliar circumstances by drawing on analogies with the old and familiar" (24). In its origin, this discursive form is akin to exemplarity. Yet casuistry never 
creates a unidimensional relationship between case and principle. While example provides a model for behavior, and thus forms the basis for articulating a rule that may be followed in similar circumstances, casuistry takes as point of departure past examples and precept, which both serve as a guide and are tested and modified in the new circumstances.

The medieval notion of the example's authoritative applicability to lived experience, and of the validity of ideal models of behavior in general, was increasingly called into question, both liberating and placing burdens of responsibility on the individual subject. Scholars like Hampton, Stierle and Rigolot have made much of the early modern "crisis of exemplarity," and a turn toward open-ended dialogue and even individual rumination. We emphasize how this entire discussion can be reframed from the perspective of casuistry, particularly with the subjective consultation of conscience in probabilism. This doctrine was developed by the Dominican Bartolomé de Medina and consisted in the idea that it is licit to follow an opinion even though the contrary one is more probable - that is, advocated by majority opinion (Medina I-II, q. 19). Its appeal seems to rest upon resistance to a schematic or statistical plausibility. Such an openness to the "benefit of doubt" allows for the exercise of individual conscience. As the contributions in this volume illustrate, the literary notion of verisimilitude, and the poetic freedom it affords, has ties with the development of probabilism. Casuistry can be seen to arise amidst the crisis of exemplarity, just as early modern narrative reframes the exemplary tradition. The richly diverse background of such narratives extends back to this tradition and to the literatura sapiencial of the Middle Ages, from Petrus Alphonsi's Disciplina Clericalis (12th Century), to El Sendebar (circa 1250), Calila e Dimna (circa 1250), and in some ways culminating in Juan Manuel's El conde Lucanor (1350). These works are also crucial to casuistry, as they present and attempt to make sense of myriad dilemmas and circumstances, many coming from eastern narrative and folkloric traditions. When the Italian Renaissance novella took over this heritage, it often jauntily violated the exemplary function of narration. However, with the Counter-Reformation such playfulness became suspicious. This is where casuistical taxonomy and its versatility in "finding" an ethical solution provides a loophole. The lack of clear-cut didacticism can be cast as a necessary subtlety of investigation (see Albert, in this volume). In this respect Cervantes' status as the creator of a distinctly Spanish version of the novella's claim on exemplarity is justified: the gap between a protagonist's failure and poetic justice is to be bridged by the interpretative probabilism of the individual reader. 
To sum up: original exemplary narratives attempt to illustrate laws and precepts with the narrated events, which might edify the reader with rules to live by. Casuistry saturated this narrative tradition with a multiplicity of possible solutions, thereby extending the narrative horizon and ethical competencies of the early modern subject.

To be sure, early forms of casuistry did resemble exemplarity. The tuciorismo (or "tutiorism," the decree to follow the "safest path") expounded in Juan Polanco's Directorium breve (1560), similarly promoted the distillation of circumstance to one clear rule that, in the interest of saving one's soul, must be heeded (cf. Braun and Vallance). Bartolomé de Medina's (Breve instrucción de cómo se ha de administrar el sacramento de la penitencia 1579) and Francisco de Toledo's (Instrucción de sacerdotes 1596) insistence on probabilismo brought accusations (as mentioned, most famously from Pascal) of laxism and political expediency. In practice, such sophistry undoubtedly took place; but the present volume reflects how figures such as Medina and Toledo were responding in a sincere manner to momentous shifts of their epoch.

As casuistry developed from its scholastic roots and the authoritative norms of tutiorism in the Middle Ages to the expansion of agency in full-blown probabilism in the 16th century, it extended - as noted - well beyond the confessional, becoming increasingly relevant in a progressively more literate culture. The scholastic method was not so much supplanted as it was integrated with the rhetorical, epistemological and civic concerns of humanism.

\section{$5 \quad$ Casuistry Permeating Different Fields of Knowledge}

In the words of Henry Sullivan, casuistry was "an offshoot of theology that became a method of mind" (51). It forms a sort of epistemology, one that registers the destabilizing yet also liberating experience of an ever more contingent world. With its testing of precepts amidst the vagaries of circumstance, casuistry becomes a mode of imaginative argumentation and inquiry. Not only does it permeate jurisprudence, economy, theology and medicine; casuistry evolves hand in hand with skepticism, nominalism, a renewed interest in rhetoric, the so-called crisis of exemplarity, an emerging awareness of subjectivity and the limits of reason, a defense of free will, and the rise of absolutism and Reason of State. With regard to politics, Anthony Cascardi notes how Machiavelli (a figure much reviled while unquestionably also influential in early modern Spain) called for "a new kind of discourse - not to the discourse of the philosophers, but to a rhetoric of examples and commentary designed 
to illuminate what is most effective" (Cascardi 16). Casuistry in medicine and natural philosophy helps us better understand affect, a significant aspect of the literary works under question. To take the concerns of many prominent theories of the novel, we can say that the arc of casuistry, especially in the bloom of probabilism, points toward modernity.

The present volume explores the discourse and methodologies of casuistry in early modern Spanish literature. In doing so, it proposes to fill a significant gap in Peninsular literary studies. Jolles' morphological analyses already indicate that the casuistical Sprachgebärde ('linguistic gesture') is an important prerequisite for the novella. This is exactly our point of departure: to better understand how the alleged (pre)modern subjectivity is fashioned, this volume will trace the specific "balancing" (Jolles) of casuistry in different narrative genres of the Peninsula. Yet, we want to emphasize that we do not claim an exclusive appropriation of casuistical inquiry to imaginative literature. We rather deem casuistry as a mindset that captures and at the same time informs various modes of communication. The effect of the transition from oral to print culture on argumentative structuring and dissemination is also given attention (see Bidwell-Steiner, Scham, Traninger in this volume). In this spirit literary narratives also feed back into Jesuit moral reasonings.

In the realm of imaginative literature, casuistry has primarily been considered in light of the comedia by scholars like Kallendorf and Gómez Canseco. However, as Josephine Donovan suggested, one might also turn to casuistry to provide an alternative history of prose narrative - or, at least, a significant modification of it. Recalling Ortega y Gasset's (1984) celebrated assertion that the modern novel, initiated by Don Quijote, discovers that individuals are comprised of self and circumstance ("Yo soy yo y mi circunstancia"), the contemporaneous flourishing of casuistry is indeed noteworthy. The contributors to this volume show how different genres developed both from and with casuistry, from the narrative and rhetorical strategies deployed, to the very source material upon which they draw. We do not mean simply to point out the striking parallels between the concerns of casuistry and those reflected in the innovations of early modern imaginative literature. Specific instances of influence and source appropriation are also revealed and examined. Our call for a reappraisal of casuistry in early modern Spain is intended to provoke a rethinking of literary history, including the very rise of what we have come to call the modern novel. 
As mentioned, the relative lack of attention to Spanish casuistry perhaps owes to its image as a sophistical justification of suspect behavior and political expediency. In Pascal's influential denunciation of Jesuit "laxism" in his Lettres provinciales (1657), many of the primary Spanish thinkers, including Molina, Suárez, Valencia, Vásquez and Escobar, are accused of a pernicious duplicity: "qu'ils couvrent leur prudence humaine et politique du prétexte d'une prudence divine et chrétienne; comme si la foi, et la tradition qui la maintient, n'etait pas toujours une et invariable dans tous les temps et dans tous les lieux" (Cinquiéme lettre). As Ginzburg recently showed, the making of Pascal's famous diatribe is in itself a sort of mystery plot, for it relies on other texts of his Port Royal circle of friends, with Charles Perrault's brother Nicolas as mastermind: "Pascal seems to have used Perrault's work-in-progress to find his way in the maze of casuistical literature" (Ginzburg 289). And the resulting mockery would be taken up by famous French authors like Molière.

Countering the black legend following the Port Royal circle, Caro Baroja pointed out that the Jesuits in fact practiced a range of casuistry, developing from a rigorist tutiorism, which sought the sole correct authority to which one then unquestioningly submits, to the individual responsibility and agency of probabilism, in which various authorities are examined, and the final decision taken based on particular circumstance and "conscience." Far from a capricious rationalization, probabilism incorporates the Ciceronian premise that absolute certainty is impossible, that one must always deal with probabilities, and that the probabilities are contingent upon circumstances.

The curriculum (ratio studorium) of the Jesuit colegios, with their weekly discussion of doubtful cases (casos dudosos) and arguments in utramque partem, also included an emphasis on the examination of conscience, which in turn extended to political advisers who dealt with the conscience of the king and issues of Reason of State. Such inwardness and acknowledgement of subjectivity - bordering on a recognition of the relativity of truth claims resonated with the revival of classical skepticism. These psychological and epistemological developments found fertile ground in the context of the vertiginous flow of knowledge and goods from the New World, religious schisms, scientific discovery, and unprecedented access to and study of ancient texts. On the foundations of Artistotle's assertion that we must deal with claims that are true "for the most part" (Ethics), to Cicero's injunction that things are not true or untrue, but rather more or less probable (De Officiis), to the radical skepticism of Francisco Sánchez' Quod nihil scitur (1581), the casuists' 
emphasis on circumstance, individual experience, and gradations of certainty and uncertainty formed part of the more general revolution of consciousness in the epoch. It is the same revolution, often couched in the now highly recognizable terms of modernity, which we associate with novelistic discourse.

\section{The "Poetics" of Casuistry}

All of this underlines the relationship between casuistry and the theories of verisimilitude and narrative cohesiveness elaborated by the Neo-Aristotelians, not to mention the concerns with the perils of narration emphasized by the Platonists, as well as humanists such as Juan Luis Vives. Along these lines, Roberto González-Echevarría goes as far as to claim that "[c]asuistry entails a whole program of representation that is more detailed, technical, and stringent than the one inherited from traditional literary sources and practices" (31). As Donovan and others have suggested, the often sensational "cases" presented in the thousands of pages of manuals in the period (many re-issued in several editions, and published in Spanish rather than Latin to reach as wide an audience as possible) may well have served as a rich vein of material for artistic elaboration in contemporary narrative fiction. Del Río Parra aptly points to the vast range of situations recorded in the casos as comprising an intrahistoria, the vital substrate of human experience in early modern Spain. As Julio Caro Baroja put it, casuistry opens up "un mundo de oscurísimas realidades psicológicas y ... la enorme variedad de modos de comportarse los hombres en unas sociedades dadas" (525). González-Echevarría makes a similar case for the contemporary legal record, which he rightly considers a field of mutual pollination with casuistry.

The famous Jesuit "hexameter" indicates the casuist's interest in fully understanding the context of an action. To take an example common in picaresque novels (see below), we might apply the hexameter to a transgression against the Seventh Commandment (No hurtarás): Who stole, what was stolen, why, by what means, when? There is a concern with judging according to the context in which the event occurs, and observing the Ciceronian injunction to assess the probable according to factors such as person, place, customs, laws, and the times (Maryks 2016). Factors relating to gender, age, intention, or even mitigating states such as anger or inebriation could be taken into account. As Azpilcueta warned, the confessor must be tactful in questioning the penitent, lest new and pernicious ideas be transmitted: "y no [preguntar] de los pecados ocultos que los muy maliciosos han inventado, sino tan cauta y disimuladamente, y por tales circunloquios que si los hizo los diga, y si no los hizo, no los 
aprenda" (Manual de confessores y penitentes 1554). As Bartolomé de Medina noted, the dynamic was also precarious for the confessor himself: "que muchas vezes estos tales [confesores] por hablar con ellas, sienten ciertas titilaciones y humedades sin quererlo" (Breve instruccion de como se ha de administrar el Sacramento de la Penitencia 1580). Needless to say, the Commandment in question here is the Sixth, which occasioned myriad sub-categories and the application of specialized vocabulary. The manuales even contained advice to the penitents regarding effective recounting of their actions, including what sorts of detail were essential, and which could be omitted (see Scham, in this volume). Despite the nuanced terminology, gradations, categories and prurient interest inspired by transgressions of the Sixth Commandment, Teófanes Egido has pointed out that the Seventh actually occupied the casuists to a greater degree. As it was conceived as pertaining to theft and justice more broadly, no hurtarás was also considered in light of the urgent early modern debates about the permissibility of charging interest, or setting proper prices and salaries, among other matters pertaining to economics and business. In the context of increasingly international trade and a nascent mercantilism, ${ }^{1}$ the traditional prohibitions against usury were no longer in step with the times. With its exploration of varieties of leisure (of nobility and of rogues), of work, and of thievery and deception in all its forms, the emerging picaresque genre engaged the very present concerns of the casuists.

\section{Genres as Cases in Point}

A focus on picaresque works comprises a large part of this volume. Already the famous precursor of the genre, Fernando de Rojas' La Celestina, points to casuistical reasoning as a decisive element of the discourse's referential function. In "Justice Blindfolded: Law and Crime in La Celestina," MARLEN BIDWELL-STEINER examines the shifting value systems of love, sex and honor as they relate to the peculiar "death cases" represented in the work, calling for a reassessment of the notions of crime and punishment pondered by the intellectual circle of the law student Fernando de Rojas. As she shows, the tensions between different legal conceptions allow for multifaceted characters, which invite the readers to subjective interpretations. In the actual picaresque "prototype", this trend becomes constitutive of the genre: Lazarillo de Tormes negogiates a "caso" that remains pending until the very end of the protagonist's life-writing.

1 A field that has been elaborated by Cavillac 1994. 
EDWARD FRIEDMAN's detailed revisiting in "Artful Rhetoric: The Case of Lázaro de Tormes" illustrates the circumstances and rhetorical stances that are in play to make sense not just of the caso referenced in the prologue (supposedly having to do with Lázaro's wife and the archpriest), but, perhaps more importantly, of his entire life trajectory, with its qualified social ascendance and compromising behavior. Along with an incisive casuistry of honor accompanied by the mitigating leitmotif of hunger, Friedman shows how Lazarillo de Tormes delivers a probabilistic examination of case morality: "The assessment of ethical points and, therein, issues of right and wrong are supremely indeterminate, prompting dialogue from many vantage points." (see p. 54 in this volume). Given the prominence of the text, one is inclined to hypothesize about its impact on moral casuistry. From the caso that forms the narrative premise of Lazarillo de Tormes, to the derisive parody of ethical rumination in La picara Justina, the picaresque is permeated by legalistic and casuistical discourse. As Michel Cavillac has argued in numerous recent studies, Mateo Alemán's picaresque masterpiece not only contains a sustained examination of economic casuistry, but also culminates in the dramatization of a central concern of the foremost political casuists, who were strenuously trying to come to terms with Machiavelli's The Prince: the very notion of Reason of State (Cavillac 2010, 2007). In the present volume, DAVID ALVAREZ ROBLIN examines the tenuous and - from a jurisprudential perspective, foundational - relationship between revenge and just punishment on two fundamental levels: that of character within the narrative, as the eponymous anti-hero of Guzmán de Alfarache attempts to redress his grievances without falling into the base behaviour he purports to critique in his moralizing digressions; and that of the author himself, as Mateo Alemán confronts the apocryphal Guzmán de Alfarache in his own "authentic" second part (1604). The result is a fascinating look at the casuistry of "street crime" as well as that which might distinguish literary theft from licit appropriation - that is, the casuistry of artistic creation. As intimated above, La Pícara Justina scoffs at Guzmán's “conversion," mocking the casuistical discourse of his narration. DAVID MAÑERO LOZANO'S contribution to the volume examines how López de Úbeda presents a sequence of cases that are inimical to the moral principles expressed, resulting in a parody that calls into question the picaresque fictions' edifying, doctrinal pretense.

An almost complementary narration of pre-modern subjectivity is elucidated by ANITA TRANINGER in "The Exploration of Circumstance: Casuistry and the Emergence of the Novela Bizantina in Alonso Núñez de Reinoso's Historia de los amores de Clareo y Florisea, y de los trabajos de Ysea (1552)." From a comparative angle, Traninger shows how the experiences of displacement and destitution represented in the novela bizantina generate a staging 
of applied ethics. Reinoso's "ego-document" has a female narrator, a gender switch that brings innovations to the traditional, putatively "conservative" representational mode of romance. Here we would emphasize the substantial role casuistry plays in the emergence of new literary forms and the transformation of existing ones, as they both critique established genres and seek out novel ways to make sense of a perplexing world.

If the picaresque arises as a "counter genre" (to use Claudio Guillén's term), creating something new in opposition to traditional romance forms, the novella appropriated and innovated promiscuously, facilitating the cross-pollination that gave rise to the novel. In "The Lawyers' Tales: Legal Casuistics and the Spanish Golden Age Novella (Cristóbal Suárez de Figueroa, Alonso de Castillo Solórzano)," MECHTHILD ALBERT delves into the variegated field of the misceláneas and short narratives, revealing the casuistical structures at work in two of the major figures of the genre. The comparison fleshes out the differences between a rather traditional use of exemplarity and a more casuistical one. With particular attention to legal casuistry, Albert's essay resonates with the preceding contribution of Bidwell-Steiner.

Since casuistry calls into question the very applicability of example and precept to the disorderliness of the everyday world, and is a major force behind the rising awareness of the reductive insufficiency of established modes of representation, argument and explanation, one is compelled to examine the dramatization of such disjunctions in Cervantes. While Don Quijote is a recurring touchstone throughout the volume, in "Comic Casuistry and Common Sense: Sancho Panza's Governorship," M ICHAEL SCHAM contends that Sancho Panza, as Governor of Barataria, embodies many aspects of the ideal ruler as set out in contemporary casuistical tracts on right rule and Reason of State. Governor Sancho's improvisations and inimical linguistic usage, in turn, provide an illustration of the casuistical process in the emergence of novelistic character.

With the discovery of the New World, the search for applicable precept becomes as confounding as it is urgent. JOSÉ CÁRDENAS BUNSEN analyses the renewed scrutiny of theological tenets and canon law as figures such as Bartolomé de las Casas attempted to come to terms with the practice of human sacrifice in the Americas. In "Opinion, Idolatry, and Indigenous Consciousness: Bartolomé de las Casas' Approach to Human Sacrifice," Cárdenas Bunsen brings early modern ethnography and historical writings under the purview of casuistry. In his fascinating reconstruction of Las Casas' insistence on a deeply ethical awareness of the indigenous subjects in the Americas, he offers a valuable contribution to early modern Postcolonial Studies.

Circling back to the genre that first attracted the attention of serious casuistry studies relating to Peninsular literature, HILAIRE KALLEndorf assesses 
the current state of casuistry scholarship in the comedia, with a focus on "Staging Penance: Scenes of Sacramental Confession in early modern Spanish Drama." Drawing upon the rich quarry of Jesuit drama dealing with the casuistry of conscience, Kallendorf reveals a remarkable range of plays depicting successful and failed confessions. A further type of "case study" is thus shown to be at the heart of innovations in early modern Spanish poetics. In sum, this volume significantly develops what Childers termed the "empty lot" of Spanish casuistry studies, while pointing the way to new areas of inquiry.

In conclusion, the relationship between casuistical argumentation and literary invention is polyvalent. The nuanced scrutinization of circumstance corresponds to complex narrations and multifaceted characters. As many of the contributors to this volume show, a result is often the creation of a "casuistical reader," who must attempt to resolve lingering dissonances. Not least, the numerous epigones of successful early modern texts prove that such an openness enhances the reader's ability to form their own imaginary cases (as, for example, David Álvarez Roblin shows with respect to Mateo Alemán's imitator and "rival"). Yet, the subtlety of high casuistry also provides cover for unorthodox and even subversive approaches, since the pattern of an exemplary claim can be superimposed on a plot rife with vicissitude and complicated circumstances, often compounded with the rhetorical register of irony.

The different essays gathered here follow these ingredients as they enter the crucible of early modern discovery, crisis and innovation. In addition to a renewed appreciation of the centrality of casuistry in early modern Spanish culture and literary production, this volume offers an original perspective on the development of early prose narrative.

\section{Works Cited}

Bidwell-Steiner, Marlen. Das Grenzwesen Mensch: vormoderne Naturphilosophie und Literatur im Dialog mit postmoderner Gendertheorie. Berlin: de Gruyter, 2017.

Braun. H.E. and E. Vallance (eds.). Contexts of Conscience in Early Modern Europe, $1500-$ 1700. Basingstoke and New York: Palgrave-Macmillan, 2004.

Caro Baroja, Julio. Las formas complejas de la vida religiosa: religión, sociedad y carácter en la España de los siglos XVI y XVII. Madrid: Akal, 1978.

Cascardi, Anthony J. Cervantes, Literature and the Discourse of Politics. Toronto: University of Toronto Press, 2016.

Cavillac, Michel. Guzmán de Alfarache y la novela moderna. Madrid: Casa de Velázquez, 2010. 
Cavillac, Michel. "Atalayisme” et picaresque: la vérité proscrite. Bordeaux: Presses Univiersitaires de Bordeaux, 2007.

Cavillac, Michel. Pícaros y mercaderes en el Guzmán de Alfarache. Granada: Universidad de Granada, 1994.

Childers, William. "Hispanic Casuistry Studies: Room to Grow." Hispanic Review 79.2 (2011): 317-326.

Del Río Parra, Elena. Cartografías de conciencia española en la Edad de Oro. Mexico: Fondo de Cultura Económica, 2008.

Donovan, Josephine. Women and the Rise of the Novel, 1405-1726. NY: St. Martin's, 1999. Egido, Teófanes. "Los casos de conciencia y la conciencia de los casos." Las Españas que (no) pudieron ser: herejías, exilios y otras conciencias (s. XVI-XX). In Las Españas que (no) pudieron ser. Ed. Manuel Peña Díaz. Huelva: Universidad de Huelva, 2oog: 93-113.

Ginzburg, Carlo. "Preface". A Historical Approach to Casuistry. Norms and Exceptions in a Comparative Perspective. Eds. Carlo Ginzburg and Lucio Biasiori. London/New York: Bloomsbury, 2019: xi-xx.

González Echevarría, Roberto. Love and the Law in Cervantes. New Haven: Yale UP, 2005.

Grice-Hutchinson, Marjorie. "The concept of the School of Salamanca: Its Origins and Development." Revista de historia económica 7 (1989): 24-35.

Hampton, Timothy. Writing from History: The Rhetoric of Exemplarity in Renaissance Literature. Ithaca: Cornell UP, 199 o.

Ife, B.W. Reading and Fiction in Golden-Age Spain: a Platonist Critique and Some Picaresque Replies. Cambridge: UP, 1985.

Jolles, André. Einfache Formen. Legende, Sage, Mythe, Rätsel, Spruch, Kasus, Memorabile, Märchen, Witz. Berlin: de Gruyter, 2017 (Saale: Niemeyer 1930).

Jolles, André. Simple Forms. Trans. J. Schwartz. London/New York: Verso, 2017.

Kahler, Erich. The Inward Turn of Narrative. Princeton: University Press, 1973.

Kallendorf, Hilaire. Conscience on Stage: The Comedia as Casuistry in Early Modern Spain. Toronto: University of Toronto Press, 2007.

Maihold, Harald. "Ich Sündige, Also Bin Ich." Zeitschrift des Max-Planck-Instituts für Europäische Rechtsgeschichte 22 (2014): 363-65.

Maryks, Robert A. "Rhetorical Veri-similitudo:Cicero, Probabilism and Jesuit Casuistry." Traditions of Eloquence: The Jesuits and Modern Rhetorical Studies. Eds. Cinthia Gannett and John C. Brereton. Fordham University, 2016: 6o-72.

Maryks, Robert A. Saint Cicero and the Jesuits: The Influence of the Liberal Arts on the Adoption of Moral Probabilism (Catholic Christendom, 1300-1700). Aldershot: Ashgate, 2008.

Melé, Domènec. "Early Business Ethics in Spain: The Salamanca School (1526-1614)." Journal of Business Ethics 22.3 (1999): 175-189. 
Mitchell, J. Allan. "Rhetorical Reason: Cases, Conscience, and Circumstances." Ethics and Exemplary Narrative in Chaucer and Gower, 33, Boydell and Brewer, 2004: 22-35. Ortega y Gasset, José. Meditaciones Del Quijote. Ed. Julian Marias. Madrid: Catedra, 1984.

Pascal, Blaise. Les lettres pronvinciales. Paris: Gallimard, 1987.

Rigolot, François. "Problematizing Renaissance Exemplarity: The Inward Turn of Dialogue from Petrarch to Montaigne." Printed Voices: The Renaissance Culture of Dialogue. Eds. Jean-François Vallée and Dorotea Heitsch. Toronto: University of Toronto Press, 2004: 3-24.

Stierle, Karlheinz. "Three Moments in the Crisis of Exemplarity: Boccaccio-Petrarch, Montaigne, and Cervantes." Journal of the History of Ideas 59.4 (1998): 581-595.

Sullivan, Henry. "Moral Probabilism and Casuistry in Spain during the Counter Reformation." Tirso de Molina and the Drama of the Counter Reformation. Amsterdam: Ropodi, 1976: 40-51.

Velasco, Jesús R. Dead Voice: Law, Philosophy, and Fiction in the Iberian Middle Ages. Philadelphia: University of Pennsylvania Press, 2019. 


\title{
Justice, Blindfolded: Law and Crime in the Celestina
}

\author{
Marlen Bidwell-Steiner
}

\begin{abstract}
La Celestina is a breakthrough in the development of Spanish narratives from educational purposes towards multi-layered literary worlds and thus crucial for the interaction between casuistry and imaginative literature. The plot's casualties are framed by soliloquies referring to legal and ethical questions. On a rhetorical level, law is present in the master trope of blind(folded) justice. Combining a close reading of these soliloquies with contemporaneous casuistical writings and an iconological search for evidences elucidates the intention of this contested masterpiece.
\end{abstract}

\section{Keywords}

Celestina - casuistry - justice - iconology - Cisneros - Nebrija

The Tragicomedia de Calisto y Melibea (around $1500 / 1507)^{1}$ is one of the most debated texts in Hispanic literary studies. Despite the persistent interest of experts from all over the world, La Celestina - as the text became known in Spanish literary memory shortly after its first editions - still remains an enigmatic work. One of its mysteries concerns authorship, and already comes to the fore in its preliminary texts. In "El autor a un su amigo" the writer gives us some information about the origins of the work: he allegedly composed it as a sort of leisure activity while preparing for his final exams in legal studies. Furthermore, he claims to have written it after having found the text of the first auto, whose possible authors (Juan de Mena and Rodrigo Cota) he discusses. In a rhetorical feint, he insists on not disclosing his own name. Yet, there is the ensuing acrostic in which Fernando de Rojas professes he at least finished ("acabó") the comedia of 16 autos. And to complicate the whole issue

1 The dating of 1507 refers to the oldest Spanish edition of the tragicomedia from Zaragoza. Yet already in 1506, there appeared a translation in Rome, and the afterword of the corrector Alonso de Proaza points to the year of 1500 . There is an ongoing debate about the archetype of the tragicomedia and its relationship to comedia with the oldest surviving versions from 1499, 1500 and 1501. A significant edition of the tragicomedia is Valencia 1514. For the question of authorship and editorial history of the text see Serés $361-401$. 
even more, we have the preface to the tragicomedia of 21 autos, which links its additional interpolations to debates with the author's friends over the semantics of the comedia:

Así que cuando diez personas se juntaren a oír esta comedia en quien quepa esta diferencia de condiciones, como suele acaecer, ¿quién negará que haya contienda en cosa que de tantas maneras se entienda? ROJAS 20

My essay takes the lead of Celestina's introductory voice at its word, since this paratext already refutes a clear-cut message of an alleged reprobatio amoris by means of an exemplum ex negativo. Although it is not possible to reconstruct such an early 16th-century "battle of words" over the significance of the plot, it might help to identify some competing voices that possibly inform its peripeties. To trace them, I would like to elaborate on the "diferencia de condiciones" and expose them to the professional battlefield of La Celestina's author namely, jurisprudence. In this field of utrumque ius, two different traditions of casuistry meet: legal students had to become versed in Roman law and in canon law. In medieval and early modern Spain, these two written corpora interacted and sometimes competed with feudal customary law:

La solución fue considerar el derecho romano como ius commune para las cosas temporales; el canónico como ius commune para las cosas espirituales; y el derecho local y consuetudinario como una suerte o clase de derecho especial [...].

JUSDADO RUIZ-CAPILLAS 333

In this essay I will identify frictions between these different legal systems. As the tragic events of La Celestina's plot lead to death, they tend towards the spiritual sphere and therefore will mainly be read against the backdrop of texts from the corpus of canon law. Subsequently, discrepancies between canonical and civil law will be elaborated. Such conceptual clashes become apparent in a passage of the Celestina that does not belong to the so-called "primitiva comedia" - the shorter first version of the text ${ }^{2}$ - but instead constitutes an

2 This labeling was coined by Marcel Bataillon (54-76) for the shorter - and allegedly - older version of the text; this opinion, however, has been quite contested ever since Charles Faulhaber discovered the Celestina de Palacio in 1990, a fragmented manuscript of the comedia, which contains elements closer to the tragicomedia (Faulhaber 1990, 1991). For discussions on the editorial fortune of the text see Serés $382-401$. 
interface for Celestina's transformation into a tragicomedia: the protagonist Calisto's soliloquy at the end of auto 14. In what we might call a stream of consciousness, Calisto reflects on the three casualties that have occurred so far: after providing him access to Melibea, the object of his desire, the procuress Celestina has been stabbed to death by his two servants, who have in turn been hanged immediately afterwards.

The following narratological analysis will show how a society in flux evinces not only changing norms but also sophisticated cultures of play - including, under the auspices of the new printing technology, literature. In this context, a close reading of Calisto's soliloquy helps to shed light on the author's playful interweaving of competing options of meaning. ${ }^{3}$

Interestingly, every case of death in the diegeses is framed by similar meditations. One is Melibea's confession to her father Pleberio after Calisto's accident, a fatal fall from the wall of their "garden of lust" in the penultimate auto. Another such meditation is Pleberio's famous lament over the vicissitudes of the fickle goddess Fortuna, when he is confronted with the suicide of his daughter at the very end of the text. Yet these two monologues also appear in the comedia, whereas Calisto's musings form the intersection of the additional five autos that change the text into a tragicomedia. Therefore, Calisto's soliloquy constitutes an important hinge of the plot's overall semantics, also impacting the meaning of Melibea's and Pleberio's monologues, as will be shown after a thorough analysis of Calisto's cogitations.

\section{Circumstantial Evidence?}

To begin with, I will confront the protagonists' reflections with two almost contemporaneous instructions for the inspection of guilt during confession, the Libro sinodal and the Confessional del Tostado. Calisto's monologue highlights the circumstances of the plot line and therefore (albeit obliquely) echoes casuistical speech. This becomes obvious when examined in relation to what later became labelled the Jesuit hexameter - a mnemonic already established in the Middle Ages, e.g., in Gonzalo de Alba's Libro sinodal of 1410: "Quis, quid, ubi,

3 Consolación Baranda set a similar track in confronting the passage with texts by Fernando de Roa, a famous jurist at the University of Salamanca at the time of Celestina's origin. It is a valuable resource, yet in examining Calisto's complaints as indicators of social reality, Baranda pursues an opposite - or perhaps complementary - objective to my narratologically oriented analysis. 
per quos, quotiens, cur, quomodo, quando: Quidlibet obseruet, anime medicamina dando" (Gonzalo de Alba 221).

Bishop Gonzalo de Alba directed his text "a los que cura tienen de animas" (Gonzalo de Alba 177). The fact that the text's purpose is not primarily pastoral but catechetical makes all the more apparent how meticulously the specific circumstances of each case (read: sin or lapse) are discussed in medieval confessionals (Soto Rábanos 441). An important catalyst for the genre was the fourth Council of Lateran (1215); from then on, the sacrament of penitence became crucial for pastoral care. With the printing of such texts in the vernacular at the turn of the 16th century, the Spanish populace became ever more proficient at examining their consciences, sometimes even complaining about the lack of sophistication on the part of their confessors (O'Banion 338).

Evidently, the Libro sinodal had a doctrinal purpose, and thus not only encompasses penance but all the other sacraments, the so-called artículos de la fe, the seven virtues, etc. It belongs to an authoritative scholastic tradition relying on the Corpus Iuris Canonici (Sánchez Herrero 1079). The Libro sinodal's salient character of orthodoxy contrasts with another influential text, the Confessional del Tostado, which notably challenges some Catholic practices (cf. Bechtel). It was written by Alfonso Fernández de Madrigal (ca. 1410-1455), nicknamed Tostado, who studied law at the University of Salamanca, where he later became rector of the Colegio Mayor de San Bartolomé and was famous for his erudition, as is evidenced by the compliment: "saber o haber escrito más que el Tostado" (Saquero Súarez-Somonte/González Rolán 87).

Without further specification, a "confisario" is also listed in the book inventory of Fernando de Rojas (Infantes 30). Of course, there is an ongoing debate on whether Rojas was the exclusive author of the tragi/comedia, and his acquaintance with Tostado's Confessional cannot be proved. Nevertheless, the Confessional is a significant text for understanding Calisto's casuistical argumentation, since in the (spatial and temporal) vicinity of the Celestina there are few other books which saw as many editions as Tostado's text. Moreover, one much-discussed source of the Celestina, the Tratado de cómo al hombre es necesario amar, is also attributed to Tostado (see Paolini; Cátedra 113-141). With his academic endeavors, Tostado initiated a flourishing humanism at the University of Salamanca.

Both texts, the Libro sinodal and Tostado's Confessional, help us to reconstruct contemporaneous moral debates as they informed imaginative literature in various ways. Concerning the act of penance, both texts adopt the common pattern of such manuals: after describing the ritual setting and necessary habitus of a penitent, they mainly debate the saligia - the "palabra mágica" (Soto 
Rábanos 417) or acronym for the seven capital sins, Superbia, Avaritia, Luxuria, Ira, Gula, Invidia, Acidia. Tostado goes without mentioning the term saligia and even changes the acronym's order into soberbia, lujuria, gula, envidia, ira, pereza (= acidia) and avaricia. Such a rearrangement is highly significant, since the formula was meant to become habitual, repeated over and over. His prioritizing of lust reflects a concern for sexual mores in 15th-century Spain, especially on the part of practicing and aspiring clerics. After elaborating on the circumstances in each of the sins, both authors follow with an explanation of the Ten Commandments, sometimes recapitulating major elements. Gonzalo de Alba proceeds slightly differently, offering a chapter exclusively on the circumstances of capital sins.

Indeed, these texts provide a comprehensive, meticulous inspection of individual mis/behavior for confessor and penitent. When every minor detail is divulged, the outer and inner - material and psychic - aspects of a penitent's vices help flesh out each unique "caso." This in turn can be understood as a narrativization or emplotment of the sacrament of penance. ${ }^{4}$ As such, these penitential texts underscore the individual's responsibility and thus foster the process of subjectivization: presumably, exhaustive pastoral monitoring over the liturgical year with at least one major confession enhanced the selfawareness of every community member. The whole process must have necessitated soliloquies to prepare for the act of penitential purification, since the instructions repeatedly stipulate a detailed oral description of the sin committed (Gonzalo de Alba 211).

Calisto's monologue reads like a preposterous version of such a preparation for penance. Considering this, what is he really pondering?

¡Oh mezquino yo, cuánto me es agradable de mi natural la solicitud y silencio y escuridad. No sé si lo causa que me vino a la memoria la traición que hice en me despartir de aquella señora que tanto amo hasta que más fuera de día, o el dolor de mi deshonra. ¡Ay, ay, que esto es; Esta herida es la que siento; agora que se ha resfriado, agora que está helada la sangre que ayer hervía, agora que veo la mengua de mi casa, la falta de mi servicio, la perdición de mi patrimonio, la infamia que a mi persona de

4 For a discussion of sacrament and confession in Spanish drama, see Kallendorf, in this volume. 
la muerte de mis criados se ha seguido! ¿Qué hice? ¿En qué me detuve? ¿Cómo me pude sofrir que no me mostré luego presente como hombre injuriado, vengador soberbio y acelerado de la manifiesta injusticia que me fue hecha? [...] ¿Qué haré? ¿Qué consejo tomaré?

ROJAS $277-278$

As Hilaire Kallendorf (64 sig.) points out, the final question (¿Qué consejo tomaré?) is a clear indication of casuistical speech. To begin with, Calisto's first words apparently designate an awakening from his amor hereos: he seems to be acknowledging his duty to act after the execution of his servants. He almost gives the impression he has been cured of what medical casuistry would have called his melancholic wound - what was burning the day before has now cooled off: "Esta herida es la que siento ahora, que se ha resfriado." If we follow Tostado's writing, the protagonist seems to be in the ideal mood for penitence, since he exhibits the need for emotional involvement: "se deue mucho entristecer por hauer fecho tales y tantos males" (Tostado $3 \mathrm{v}$ ).

Yet Calisto's contrition is only skin-deep, because his self-perception shifts from culprit to injured party, from "la infamia que tiene mi persona de la muerte" to "hombre injuriado, vengador, soberbio y acelerado de la manifiesta injusticia que me fue hecha." One could even argue that his initial regret already only aims at his reputation, because infamia rather means loss of honor than a personal lapse. Interestingly, in this passage the protagonist assumes soberbio to be a positive personal trait; in fact, his concern for honor - "el dolor de mi deshonra" - correlates with Tostado's initial explanation of the first mortal sin soberbia: "Acerca del pecado de la soberuia es de considerar que en muchas maneras pecamos: Primeramente en deseo de honrra" (Tostado 8 v). Thus, against the backdrop of the Confessional, Calisto's first sentences already read as an ironic distortion of the confessional situation.

As an expression for social shame, infamia points to other (possible) perpetrators. And indeed, Calisto suddenly refers to such a person:

¡Oh cruel juez, y qué mal pago me has dado del pan que de mi padre comiste! Yo pensaba que pudiera con tu favor matar mil hombres sin temor de castigo, jinicuo falsario, perseguidor de verdad, hombre de bajo suelo! Bien dirán de ti que te hizo alcalde mengua de hombres buenos. Miraras que tú y los que mataste en servir a mis pasados y a mí érades compañeros. Mas cuando el vil está rico, no tiene pariente ni amigo.

ROJAS 278-279 
On the surface, this passage confirms Calisto's overall flawed character as he tries to blame the judge for his own faults. Calisto refers to his feudal privilege and the judge's obligation to Calisto's family - resulting in his awkward verdict holding the judge guilty of having executed his symbolic brothers, for he and the criados all were serving the same noble family: "Miraras que tú y los que mataste en servir a mis pasados y a mí érades compañeros."

In displacing the subject of the crime, the quis, from the servants (or himself) to the judge, Calisto's monologue betrays a subtly casuistical reframing of the circumstances of the servants' execution. This can be read as a mockery of confessional guidelines, which very explicitly warn against blaming other people (Tostado 56v). Calisto plays the "cruel act" of the judge against the homicide committed by the two servants, and in so doing gives a striking misrepresentation of the quis and the quid:

Tú eres público delincuente, y mataste a los que son privados; y pues sabe que menor delito es el privado que el público, menor su utilidad, según las leyes de Atenas disponen, las cuales no son escritas con sangre, antes muestran que es menos yerro no condenar los malhechores que punir los inocentes. ¡Oh cuán peligroso es seguir justa causa delante injusto juez! Cuanto más este exceso de mis criados, que no carecía de culpa.

ROJAS 279-280

According to Calisto, the judge as public authority committed a worse crime than the servants, since he punished - without a formal trial - their crime with execution i.e., blood, which in Calisto's perspective constitutes a violation of public law ("leyes de Atenas"). The use of privado as a noun once more emphasizes the point that these servants are not invested with legal capacity; consequently, the only possible juridical persona on their behalf would be Calisto himself. He further elaborates on the antithesis of public-private mingling quid with $u b i$, i.e., the location of the case: the crime was done in private ("y pues sabe que menor delito es el privado que el público"). Yolanda Iglesias is one of the few scholars who has linked such instances of death in the Celestina to contemporaneous juridical discourse, albeit without mentioning casuistry. She argues that medieval law considered intrusion into a private home as a more severe crime than public murder (Iglesias 63). Yet, Calisto's reflection is consonant with contemporaneous interpretations of Roman law, as the anonymous author of the Celestina Comentada proves (412) and it also is in accordance with the circumstantial norms elaborated in the Libro sinodal, where 
Gonzalo de Alba classifies crimes perpetrated in public as a greater offense, since they bear the danger of instigating imitators:

Item, si el pecado que cometio, si es publico o ascondido, ca mas peca el que peca publicamente que el que es ascondido, ca el que peca publicamente, con su mal enxienplo muchos escandalisa e corronpe.

GONZALO DE ALBA 221

Since Calisto's considerations draw on moralistic debates, it comes as no surprise that his accusation of the judge is interwoven with a reference to God: "Pues mira, si mal has hecho, que hay sindicado en el cielo y en la tierra: así que a Dios y al rey serás reo, y a mí capital enemigo" (Rojas 280). This doubling of the judge's guilt is interesting in that it insinuates a distinction between canon and civil law. Calisto's intricate argument that the judge is a wrongdoer before the king seems to refer to the patria potestas in Roman law, where household members (including servants) are alieni iuris and thus subordinated to the pater familias, who is the only one to enjoy personhood sui iuris (Benke 286). Taking a lead from our protagonist, we could even argue that the judge bears a quadruple guilt, since both servants were executed, although only one stabbed Celestina: “¿Qué pecó el uno por lo que hizo el otro, que por sólo ser su compañero los mataste a entrambos?" (Rojas 280).

Secular punitive measures do not distinguish between the actual perpetrator and the initiators of the crime - both are considered guilty: "hacientes y consintientes merecen igual pena," as Calisto concedes immediately afterwards. Our anonymous commentator mentions in this context the Siete Partidas VII, tit. I, l. 10 as one source of the argument (c.c. 419). However, there is a slight variance in moral views: although the mere intention of murder counts as a sin in itself, dirtying one's hands with the deed does make a difference. In moral debates, this raises the question of whether someone sinned actively or passively, and thus refers to the quomodo (cf. Gonzalo de Alba 222). And in light of another synodal norm, the two servants not only committed murder but also "asechanzas" ("traps", cf. Guiance), since they blindsided their victim and prevented her from obtaining spiritual help, as Celestina's last exclamation underscores: “¿Confesión!” (Rojas 261).

\section{$3 \quad$ Sophistic Argumentations}

Yet, after coming to his wits again - "Pero ¿qué digo? ¿Con quién hablo? ¿Estoy en mi seso? ¿Qué es esto, Calisto? [...] Torna en ti” (Rojas 280) - Calisto 
concludes that the judge might have had good arguments for executing both men. We now also learn that the prompt execution might be considered an act of mercy toward the perpetrators because they were already severely injured, and also because the evidence for their punishment was sufficient, seeing that they were caught in the act:

¿No ves que por ejecutar justicia no había de mirar amistad ni deudo ni crianza? ¿No miras que la ley tiene que ser igual a todos? [...] Considera que si aquí presente él estoviese, respondería que hacientes y consintientes merecen igual pena, aunque a entramos matase por lo que el uno pecó, y que si aceleró en su muerte, que era crimen notorio y no eran necesarias muchas pruebas, y que fueron tomados en el acto del matar, que ya estaba el uno muerto de la caída que dio.

ROJAS 280

Narratologically, this is quite a significant passage because at this point the soliloquy shifts focalization: whereas at the beginning Calisto addressed the other - his enemy, the judge - with "you," now his ostensible self-examination ("torna en ti") materializes on the level of discourse in contrast to the significance of the words. All of a sudden, he refers to himself with "you" and addresses the judge in the third person.

As we shall see, this strategy of self-othering is meant to reveal the protagonist's presumptuous self-aggrandizement. This plot device constitutes a rhetorical correlation to the satirical distortion of juridical discourse that then follows. Calisto recalls the legal imperative of hearing both parties with a comic twist: he denies the judge his role as arbiter and arrogates to himself the role of judging his own case. In this context, Calisto echoes an argument developed earlier in the comedia by none less than the real victim of our case here, Celestina: “¿No miras que la ley tiene de ser igual a todos?” (Rojas 259). In the face of the law, all people are equal.

However, what sounds like the triumph of the modern legal system turns out to be the young nobleman's manipulation of the judge. Calisto's further reflections contradict his earlier observation that justice should be immune to personal ties such as friendship and loyalty (" $¿$ No ves que por ejecutar la justicia no había de mirar amistad ni deudo ni crianza?”). Indeed, his conclusion namely, that the judge executed the two servants without a trial in an obvious ploy to cover up Calisto's own transgressions - clearly challenges his own line of argument. After these self-exonerating ponderings, Calisto lapses back into the passion of mad love, culminating in a prolepsis of his own death: "Quiérolo conocer, no quiero con enojo perder mi seso, porque perdido no caiga de tan alta posesión" (Rojas 281). 
Such rhetorical sophistications raise the question of what might be the purpose of adding this contradictory sermon to the articulations of an otherwise very dull protagonist. I will try to address this issue in two ways: first, by examining the semantic tension that arises in Calisto's casuistical argumentation, and second, by looking at the material evidence of the Celestina's historical records.

If we trace the development of Calisto in this passage, we initially perceive an unsettled, almost self-scrutinizing character. All of a sudden, he is aware of his social environment and the effects of his own deeds. Yet in his effort to cope with all this, he gradually regains his self-centered, lofty attitude - only to finally relapse to his state of mad love. This indicates a clear misuse of libre albedrio, which is all the more reprehensible in a character who obviously has the education and the discretionary powers to know better - as his reflections on the circumstances of the crime prove. Therefore, one reason for inserting this passage in the plot development from comedia to tragicomedia is its function as a mise en abyme, or even a metalepsis: Calisto's considerations of the deaths that so far have occurred represent an obliquely ironic, casuistical reconstruction of an action - thereby adumbrating the circumstances of his own death.

With his shift from "I" to "you" in denominating himself, Calisto's discourse invites readers to render him the object of casuistical scrutiny. Our hero thus identifies himself as the ultimate sinner in moral terms; as has been shown, in the light of Tostado's Confessional and the Libro sinodal, his list of lapses includes excessive soberbia.

Furthermore, he performs blasphemy by ascribing divine qualities to his beloved: "¿Yo? Melibeo só y a Melibea adoro y en Melibea creo y a Melibea amo" (Rojas 34), which is his confessional statement in the second auto. Throughout his courtship, Calisto adores her in terms evoking idolatry (Tostado47). Relying on the assistance of a procuress is another infringement of the First Commandment, as we read in the Libro sindical when it instructs confessors to ask their penitents: "[...] si fizo esperimientos o conjurarmento o otras cosas por aver mugeres o otras cosas [...] o fue a devinos o a devinas a tomar consejo con ellas [...]" (Gonzalo de Alba 217). Calisto's denunciation of the judge represents an offense against the Eighth Commandment (Tostado 56 ), and his sexual intercourse with Melibea constitutes one of the worst forms of adultery, estupro (cp. Gonzalo de Alba 216, Tostado 11), since he has corrupted a virgin: "onde en la Eglesia el primero lugar tienen las virgenes [...]," as Gonzalo de Alba specifies (274). Leaving all serious and minor failures aside, his list of 
sins is topped by the repetition of his illicit sexual act, which is a double transgression: Calisto not only penetrates Melibea but also her father's property, as the deed is performed in Pleberio's garden. Such an environment is a quite significant location for the hexameral "ubi" since it corroborates the setting of sin just as it metonymically represents fall, or the original sin.

Most evident in our passage is the role accrued to soberbia: Calisto conceives himself as standing above any jurisdiction. This can be seen in references to his noble descent, which he seems to link to a God-given order; in fact, he invokes a medieval hierarchy where some men are more equal than others. This reveals another semantic layer of the passage. As mentioned, the monologue creates a tension of conflicting legal systems - or in a larger context, of conflicting social systems.

Calisto clearly represents - and reclaims - a social model that in the urban context of the Celestina had become obsolete: he is unproductive, irresponsible, cowardly, and therefore a mere caricature of the medieval courtly lover (Lacarra 2001: 86).

\section{Over Her Dead Body}

These unflattering qualities are paradoxically highlighted by Melibea's praise for her dead lover in the monologue preceding her own suicide. In view of casuistry her final words are also highly questionable. Obviously, she is at least an accomplice in almost every sin of Calisto. But she is not just a passive sinner: her rationalizing strategies for downplaying her own guilt additionally depict her as a countermodel of the ideal penitent. After mentioning abominable figures of classical history such as Nero, she concludes: "Éstos son dignos de culpa, éstos son verdaderos parricidas, que no yo [...]" (Rojas 331).

One could argue that her speech does not allow for casuistical analysis because it does not follow the scheme of the hexameter. Yet, she twice uses confessional formulas: "Tú, Señor, que de mi habla eres testigo [...]" (331) and "Dios quede contigo y con ella. A él ofresco mi alma. Pon tú en cobro este cuerpo que allá baja" (335), as she addresses her father before plunging from her lofty tower. This metaphorical and discursive role reversal between father and daughter amounts to another violation of Christian norms: honor your father and mother, that is, the Fourth Commandment. A further critical point in Melibea's confession is her explicit description of their act of luxuria: "Quebrantó con escalas las paredes de tu huerto, quebrantó mi propositio. Perdí mi virginidad, del cual deleitoso yerro de amor gozamos cuasi un mes" (333). Notably, this graphic clause is another of the tragicomedia's interpolations. 
The passage not only corroborates the severity of Melibea's sin by emphasizing repetition, but its sensual vocabulary also denotes shamelessness. Similarly, Tostado's Confessional and the Libro sinodal both warn repeatedly of detailed descriptions of sexual intercourse because an audience might be seduced by it (Gonzalo de Alba 216). Furthermore, the corporal senses are the gateways for sins, and thus should not inform language (Tostado 58; Gonzalo de Alba 220).

Melibea's inclination toward worldly pleasure is obvious throughout the plot. Her first initiative of inviting the lovesick Calisto to a nocturnal conversation at her gate already constitutes quite an active transgression for an inexperienced maiden. Further evidence of her frivolous character is provided by the two young sex workers Areúsa and Elicia, who, envious of Melibea, sardonically describe her beauty-enhancement measures, such as expensive clothes and makeup (Rojas 206-207). What today might be considered a desirable social imperative was undoubtedly a sinful and pernicious behavior in the eyes of church authorities. Tostado even discusses "[...] colores y trajes/o tajos de ropas en diversos apostamientos de oro o de plata [...]" in a separate chapter of almost three pages, explaining their damaging effect of inducing lujuria (Tostado 14 v. sig.).

And in terms of ecclesiastical norms, Melibea's gravest sin clearly is suicide. In the early modern period, suicide entailed not only loss of honor but also sanctions for the family (cf. Lacarra 2007). Nevertheless, in what is perhaps a daring interpretation of Roman family law, her deed could be regarded as a restoration of her father's honor. This can be demonstrated by comparing her to a literary and historical role model who took her own life as an act of chastity: Lucretia, one of the famous exemplary female life histories in Giovanni Boccaccio's Claris mulieribus. Lucretia suffers rape without resisting in order to save the honor of her husband, since the violator Sextus Tarquinius threatened to kill her together with a male slave and to accuse the two of adultery. Immediately afterwards Lucretia commits suicide to re-establish her husband's reputation. "[T] he Lucretia story aims to create a conscience that makes a woman consider herself unworthy of living once her pudicitia is infringed," notes Nikolaus Benke in explaining the significance of Lucretia's fame within the system of classical patria potestas in Roman law (Benke 290). But some church fathers downplayed this famous female sacrifice in an almost casuistical way:

San Agustín, a diferencia de san Jerónimo y de otros padres de la Iglesia, no admite excepciones, ni en el caso de Lucrecia ni en el de las doncellas que se suicidan para proteger su virginidad.

LACARRA 2OO2: 176 
The well-known narrative substantiates Melibea's trespass, who clarifies that everything happened out of free will: "Todo se ha hecho a mi voluntad" (Rojas 329). Her insistence on following her own conscience points to what later will be known as probabilism. The fact that the servant accompanying Melibea in her last actions is actually named Lucrecia emphasizes an ironic misrepresentation of "acceptable" female suicide.

Following Christian doctrine, both Melibea's and her lover's souls will go to hell since they received neither absolution via confession nor even extreme unction. This could be one of the reasons why her father's closing speech is not a dialogue with God. Far from being a prayer, his lament conspicuously switches addressees, too: after speaking directly to his dead daughter, the father makes accusations against two rather pagan deities complaining that Fortune took his offspring from him even though this should not come under her sphere of operations, since the loss is not a worldly material good:

¿Por qué no destruiste mi patrimonio? [...] Dejárasme aquella florida planta en quién tú poder no tenías. Diérasme, fortuna fluctuosa, triste la mocedad con vejez alegre; no pervertieras la orden.

ROJAS 339

This complaint against a rupture of the generational succession is very important within a narrative obsessed with chronological data - something quite remarkable for the period. And indeed, the question of old and new orders marks the text's semantics on different levels. In Pleberio's monologue, the clash of old and new values entails a very disturbing condensed metaphorization - a metaphorization that, according to my knowledge, has not received its due attention in literary scholarship. After complaining of Fortune's vagaries, Melibea's father repeats a leitmotif of the text: "inicua es la ley que a todos igual no es" (344). Ostensibly echoing Calisto's reproach of justice, Pleberio's accusation is directed at the unfair rules of equivocal Amor's ruthless games: "Dios te llamaron otros, no sé con qué error de su sentido traídos. Cata que Dios mata los que crió; tú matas los que te siguen [...] Ciego te pintan, pobre y mozo" (345).

5 For a deeper analysis of tropes of blindness and of the authorship of the Celestina see Bidwell-Steiner 2021. 
Indeed, the iconographical form of a blind young Cupid enjoyed myriad depictions in what the art historian Erwin Panofsky has classified as "moralizing mythography" (Panofsky 104). He contextualizes the beginning of this pictorial attribute through the two conflicting Christian concepts of amor: caritas and cupiditas. After a short reconciliation in medieval courtly love, this antithesis reappears in the 14th century, where it represents unruly love in the form of a young blindfolded boy (this unknown in classical models) holding an arrow and torch (Panofsky 110 sig.). Thus, the author(s) of the Celestina revert(s) to an already well-established motif.

More startling in the context of the above passage from the Celestina, however, is Panofsky's further explanation of iconographical blindness: "Blind Cupid started his career in rather terrifying company: he belonged to Night, Synagogue, Infidelity, Death and Fortune who had also joined the group of blindfold personifications" (112). This list of appalling blind personae demonstrates unambiguously that in medieval art, blindness was the utmost negative representation of misbelief and annihilation. And some of the undesirable "companions" cited by Panofsky are present in our text: as we have seen, Pleberio starts out with a complaint against Fortune, following his daughter Melibea' suicide before daybreak; thus, Amor, Death, Fortune, Night and arguably Infidelity between daughter and parents are conflated in the motif of blindness.

But what about Synagogue? Like many other scholars, I consider Pleberio to be a converso, as suggested by the tension between his commercial activity and prosperity with his otherwise restrained and pessimistic character. This general observation is borne out by the discourse of the passage in question, as it alludes to a more prominent grief-stricken text: Pleberio's monologue can be related to the "Book of Lamentations" of the Hebrew bible, traditionally ascribed to Jeremiah. This poem is one of five parts of the Ketuvim ("Writings") and mourns the destruction of the city and the temple of Jerusalem. In Rabbinical tradition, Jerusalem is often metaphorized through Abraham's wife Sara in opposition to Hagar, her female slave. The two female figures become prominent allegories in Augustine's City of God - one representing the virtuous, the spiritual, in short, the City of Grace; the other the vicious, the carnal, the City of Natural Law (Augustine: Book 15, 2). Augustine tried to reconcile the vetus testamentum velatum with the novum testamentum revelatum by claiming the presence of the spiritual element of grace within the natural, thereby allowing Jews to participate in Christian communities, albeit in a subordinate 
position. Sara's antipode Hagar was later adopted for Christian propaganda to prevail over Jews; there, Ecclesia embodies the positive traits of Sara, whereas Synagoga refers to Hagar as an image for Judaism persisting in old Mosaic law, blind to Truth (Rove). Panofsky describes Hagar's original iconographical traits such as a broken crown, and her metamorphosis toward the blind representations of Death and Night, which "replaced the figure merely 'plunging into darkness' by a blindfold one" (Panofsky 111). Could it be possible that loveblind Melibea, leaping to her death at the crack of dawn, is a variant of blind Synagogue?

But medieval legal practice offers an alternative explanation for the prominence of this motif with regard to the ascertaining of judicial truth: Ecclesia and Synagoga embody the innocent and guilty parties in court, which often is hold right in front of the church below their personifications (Weis 65-80). This brings us to another, less terrifying personification of blind(folded)ness in Western tradition, which Pleberio also insinuates: Justice. Although Panofsky dismisses any anachronistic parallelization (the attribute of blindness for Justice becomes prominent only in the later 16th century), I cannot believe that the reappearance of equality before the law, a leitmotif of the Celestina, can be a coincidence within this specific context.

The origin of the motif of blind Justicia seems to be Sebastian Brant's Narrenschiff, published in Basel in 1494 (see Möller 111, Panofsky 110, Prosperi 36). Due to the scant dissemination of this culturally peripherical German text in Renaissance Italy, Panofsky questions the impact of its iconographical program. Adriano Prosperi further explores the semantics of Brant's blind justice both from the viewpoint of legal practices and of earlier iconographic traditions of blindness. Seemingly, Brant was a reformer who tried to overcome concurrent legal traditions in order to establish an upright, effective national jurisdiction; he was obviously well acquainted with the target of his mockery, being a trained jurist himself. Brant combined this professional background with a "radical but profoundly religious spirit, sought to point out the failure of every good rule in a human society which by now for him resembled a boatload of fools headed for shipwreck" (6o).

Two elements are conspicuous within Brant's iconography: allegories of blindness often are personifications of a negative principle, and Synagogue is the most prominent female representation of blindness. Reconstructing what I have called condensed metaphorization serves to elucidate unsettled discrepancies in the iconography of blind Justice: "The rapid success of the figure of the blindfolded goddess was influenced by familiarity with the image of the

6 Interestingly, early modern Sephardic Kabbalah seemed to have re-appropriated the allegorical Christian Ecclesia for Shekhinah, i.e. divine wisdom, as Tzahi Weiss suggested. 
Christ of the Passion" where "Justice took the place of the mocked Just One" (Prosperi 64). In this view, the mourning human Christ is an incarnation of true faith as he faces the scorning Pharisees, and thus is a precondition for the triumph of Ecclesia. In a process of parallelization, the already familiar allegory of Justice as a young maiden suddenly appears blindfolded - reminiscent of the suffering Jesus - so as to avoid being corrupted by material impressions. Blindness becomes a positive, active trait, whereas in the examples mentioned earlier it represents a passive state of ignorance. In this view, pictorial and verbal depictions of blindness and foolishness, as in the Narrenschiff, function as a paradoxical intervention for reforming juridical and ecclesial conventions.

Like this northern example, the Celestina also blends mockery and moralism stemming from a juridical culture. But are we facing only a phenomenon of mere coincidence, a sign of contemporaneity? Without being able to present conclusive proof, I would like to convey some "presumptive evidence" for a deeper intertextual interdependence between the texts/authors. First of all, the very last words of Pleberio, concluding the Celestina, are also the last addition from the reshaping process into the tragicomedia: “ ¿Por qué me dejaste triste y solo in hac lachrimarum valle?" (Rojas 347). This is highly reminiscent of the Man of Tears, the Christ of the Passion, as visualized in the above-mentioned tradition. In this reading, Pleberio appears to be a figure of liminality, having irrevocably lost his former faith and been suspended from grace. Interestingly, the "concluye el autor ..." of the tragicomedia explicitly relates the message of the overall text to Luke's narration of Christ's passion: "Amemos a Aquel que espinas y lanza,/azotes y clavos su sangre vertieron./Los falsos judíos su haz escupieron,/vinagre con hiel fue su potación" (Rojas 349).

Apart from this textual marker of an intertextual relationship between the Celestina and the Narrenschiff, it is worth noting that the inventory of the National Library in Madrid lists several versions of the Latin translation of the Narrenschiff, Stultifera Navis (1497) by Jakob Locher, and the juridical writings of Sebastian Brant. Given the juridical background of the Celestina's author(s), it seems highly probable that they were acquainted with this quite important northern colleague. Furthermore, the Madrid library houses the only Spanish edition of one of the most prominent supplements of the Narrenschiffs Latin version, the Stultiferae Naves (1500) by Jodocus Badius Ascensius. It was even released by the same publisher who issued the oldest surviving version of the Celestina (1499), also editing the Confessional del Tostado in Burgos that same year: Fadrique Biel (“de Basilea"). ${ }^{7}$

7 The version of the Biblioteca nacional de Madrid obviously was bound together with an edition from Lyon. For my argument Badius Ascensius' own activity between Lyon and Basel and Friedrich Biel's training in Basel gives further evidence (Bidwell-Steiner 2021). 
The idea that everyone is equal before the law runs as a recurring chorus through the entire text: three main characters - Celestina, Calisto and Pleberio - express it in crucial moments, emphatically mirroring the efforts of an emerging urban bourgeoisie as it attempts to supersede traditional hierarchies. At the threshold between medieval and early modern Spain we observe pogroms, riots, and a struggle for hegemony within the Spanish aristocracy. Royal efforts towards a national organization of the Peninsula were constantly threatened by tensions within its provinces. What under the reign of Carlos I would lead to the Guerra de la comunidades de Castilla (1520-22) already had its heralds at the end of the 15th century when aspiring urban elites became independent from the traditional aristocracy; in this battle, the University of Salamanca was a breeding ground for humanistic reforms with Tostado, Fernando de Roa and Antonio Nebrija as key figures.

This brings me to historical evidence for interpreting casuistical argumentation in the text (cf. Castillo Vegas). In José Luis Canet Vallés' elaborations (2008) on the fascinating editorial history of La Celestina, we learn that around 1500, the text was simultaneously published in different versions, making it one of the most widely distributed Spanish literary texts of its epoch. Although most scholars assume an editio princeps from Salamanca, ${ }^{8}$ hermeneutic efforts are constrained by the fact that both versions - the comedia of 16 acts and the tragicomedia of 21 acts - were in simultaneous circulation. Only university textbooks had a reach similar to that of the Celestina. Recognizing the fact that printers and editors involved in the different editions of the Celestina also issued academic publications, Canet Vallés links the Celestina to a university circle. In fact, the inclusion of Calisto's casuistical ponderings helps us to identify the diez personas intended in the introductory quote. Fernando the Rojas, the nominee of the acrostic and commonly held to be the author of the entire text (aside from its first act), studied law in Salamanca and was thus familiar with casuistical discourse. Nevertheless, Canet Vallés (2017: 35 sig.) doubts Rojas' single authorship - because of the enormous costs of such a publishing enterprise, and also judging from its immediate success. He proposes a far more prominent affiliation.

State-Decreed Humanism?

A crucial figure in the struggle for hegemony over the Iberian Peninsula was Cardinal Cisneros, the confessor of Queen Isabel. A son of humble hidalgos, he

8 One evidence for such a claim is the afterword of Alonso de Proaza, the "corrector" of the text, which refers to the publication year 1500 and Salamanca. 
became one of the most influential statesmen of the Renaissance and a fervent religious reformer. One of his stepping stones on the way to power was the founding of the University of Alcalá, accompanied by a sort of state-mandated humanism including projects such as the Complutensian Polyglot Bible. Canet Vallés suggests that his spirit of reform, together with his financial power, make Cardinal Cisneros a possible candidate for the spiritus rector of the Celestina, in collaboration with his friend Alonso de Proaza (who appears to be the corrector of the Valencia edition, Canet 2017: 40).

As I have tried to show with the unusual conflation of blind representations and parallels to the Northern literary text, this suggestion bears some plausibility. Indeed, a reconsideration of aequitas, or equality, was at the core of legal debates at the threshold to modernity. Late medieval canonists combined the Roman roots of this legal principle with casuistical approaches from the Aristotelian Nicomachean Ethics (re-discovered in 1245) and the Augustinian principle of mercy. In doing so, they aimed to establish a harmony between forensic and moral standards (Johnson/Toulmin 116). The realization of such intellectual endeavours doubtlessly converged with the reformatory efforts of the statesman and the churchman Cisneros.

But how do we explain the hilarious and erotic parts of the text? Should we just "take example," as the paratext (Rojas 13) advises us, and relapse into a medieval understanding of literature as exemplum? I do not think so. As I have tried to show, the tensions between and within the three monologues of the Celestina point to different world views: Calisto is a representative of the aristocracy, which will soon oppose the urban elites who bolster the power of the Catholic Monarchs. Yet, his egregious speech during sexual intercourse depicts him as more like a student who neglects courtly manners, and features the misogyny of collegiate audiences. In contrast, Calisto's (male) counterpart Pleberio could be assessed as a progressive, meritocratic urban entrepreneur; yet the text's closing passage demolishes his value system. And Melibea might pass as an allegory of Synagoga (with contemporaneous allusions to heresy) or as a late penitent executive of the "law of the Father." Then, however, her sophisticated claim of personal freedom would read as a proto-feminist statement. A similarly polymorphous personality can be attributed to other female figures of the text, namely to Celestina and Areúsa. ${ }^{10}$

Therefore, the readers have to make up their mind about the semantic excess, which is a product of a creative competition in casuistical eventualities

9 The notion is borrowed from Jacques Lacan's analysis of patriarchal societies.

10 For an interpretation of the female personae of the text see Bidwell-Steiner 2015 . 
within the genre of quodlibet. ${ }^{11}$ On one level, we can almost picture a group of academics inventing a tricky case story in the forensic debate culture of the so-called "ius controversum," where "finge" (latin for invent) is imperative for creating a legal fiction in order to test one's ability as a lawyer (Benke 2000: 12). Not insignificantly, these argumentative tensions reflect a climax in the humanistic tradition of the University of Salamanca in a moment when the sovereigns betrayed their urban allies in their efforts to introduce a more secular - and equal - order (cf. Castillo Vegas 2004). Before Cisneros could inaugurate his "own" university, he allegedly tried to take the reins of the one in Salamanca. This training post for future lawyers was the domain of another important counselor of the Queen, Antonio Nebrija. The Italian-trained humanist shared Cisneros' hermeneutic concerns. But he favored a more heterodox version of philological scrutiny in the vein of Lorenzo Valla's linguistic philosophy, which even caused him troubles with the Inquisition. In his Diccionario de derecho civil, Nebrija elaborated on the legal enigma, defining it as a paradox (Goodrich 85). Such ponderings on juridical riddles might well have been developed as a playful classroom endeavor, eventually plotting a comedia based on different theoretical and imaginary sources.

Seen in this way, Calisto's paradoxical monologue traces the juristic theory and practice from which the text originated, with inconsistencies between different approaches playfully performed in the fictional text. In a broader sense, it also reflects the different world views represented by the eminent Renaissance scholar Antonio de Nebrija and the powerful conservative statesman Cardinal Cisneros.

And this is precisely the reason why the Celestina is so important for the mutual history of the novel and of moralism. What emerges here is a specific tension between different casuistical options. The relationship between casuistry and imaginative literature is a history of increasing narrative complexity. On the one hand, this relationship sheds light on remote ludic and rhetorical cultures. On the other, it helps to reveal social tensions and shifting power relations. Considering that the heyday of moralism in Spain is only to come 150 years after the publication of the Celestina, the importance of fictional literature for molding society and its institutions cannot be underestimated. Firstly, the Celestina already presents a catalogue of circumstances like those to be found in the later School of Salamanca; secondly, it also contains an

11 The term refers to a well-known practice in medieval universities ("disputatio de quodlibet"): a candidate had to elaborate on a certain subject or case without preparation, which often generated quite funny effects. In this context, see also Anita Traninger's contribution in this volume. 
illustration of judicial practice. These twofold semantic vectors extend beyond any model of humanistic comedy and of reprobatio amoris. The interpolations of the tragicomedia consist mainly in the protagonists' reflections on the circumstances of their actions, which gives the characters a depth and liveliness not always found in the comedia. If we acknowledge the narratological basis of such a solid field as jurisprudence, we might also restore the (admittedly problematic) term "fiction" to literary studies. For the overall subject of this volume, it is important to identify the benefit of this casuistical fastidiousness: it breathes life into the simple, one-dimensional figures of exempla. This new depth is best demonstrated through Calisto. Inertly lovelorn, he starts out as one of the most boring figures in the text; but the juridical refinement of his character paves the way for narrative complexity. In narratological terms, this abject sinner is the antihero, a figure later to become an eminently attractive protagonist in European literature. The rise of the picaresque genre is an important step in this direction, as the following essays recount.

\section{Works Cited}

Anon. Celestina comentada. Eds. Luise Fothergill-Payne, Enrique Fernández Rivera and Peter Fothergill-Payne. Salamanca: Ediciones Universidad 2002.

Baranda, Consolación. "Cambio social en La Celestina y las ideas jurídico-políticas en la Universidad de Salamanca." El Mundo social y cultural de la Celestina. Actas del congreso internacional, Universidad de Navarra, junio, 20o1. Eds. Ignacio Arellano and Jesús M. Usunáriz. Madrid: Iberoamericana/Vervuert, 2003: 9-25.

Bataillon, Marcel. Erasmo y España. Estudios sobre la historia espiritual del siglo XVI. México-Madrid-Buenos Aires: Fondo de Cultura Económica, 1966.

Bataillon, Marcel. La Célestine selon Fernando de Rojas. Paris: Marcel Didier, 1961.

Bechtel, Florentine. "Alonso Tostado." The Catholic Encyclopedia 14 (1912). Ed. Robert Appleton Company New York. 21 Oct. 2020: <http://www.newadvent.org/ cathen $/ 14788 \mathrm{~b}$.htm $>$.

Benke, Nikolaus. "In sola prudentium interpretatione. Zu Methodik und Methodologie römischer Juristen." Norm und Entscheidung. Prolegomena zu einer Theorie des Falls. Ed. Birgit Feldner and Nikolaus Forgó. Wien/New York: Springer, 200o: 1-86.

Benke, Nikolaus. "On the Roman father's right to kill his adulterous daughter." The History of the family 17.3 (2012): 284-308.

Bidwell-Steiner, Marlen. "Sex Acts in the Celestina: An Ars Combinatoria of Desire." Sex Acts in the Early Modern World. Eds. Amyrose McCue Gill and Vanessa McCarthy, Renaissance and Reformation 38.4 (2015): 121-144. 
Bidwell-Steiner, Marlen. "Law New and Old: Tropes of Blindness in the Celestina." Celestinesca 45 (2021).

Canet Vallés, José Luis. "La Celestina en la 'contienda' intelectual y universitaria de principios del siglo XVI." Celestinesca 32 (2008): 85-108.

Canet Vallés, José Luis. "The Early Editions and the Authorship of Celestina." $A$ Companion to Celestina. The Renaissance Society of America Texts and Studies 9. Ed. Enrique Fernandez. Leiden: Brill, 2017: 21-41.

Castillo Vegas, Jesús Luis. "Aristotelismo político en la Universidad de Salamanca del siglo XV: Alfonso de Madrigal y Fernando de Roa." La corónica: A Journal of Medieval Hispanic Languages, Literatures, and Cultures 33.1 (2004): 39-52.

Faulhaber Charles, B. "Celestina de Palacio." Celestinesca 14.2 (1990): 3-40.

Faulhaber Charles, B. “Celestina de Palacio: Rojas's holograph manuscript?” Celestinesca 15.1 (1991): 3-51.

Gómez Moreno, Ángel. "La torre de Pleberio y la ciudad de La Celestina (un mosaico de intertextualidades artístico-literarias ... y algo más)." El Mundo socialy cultural de la Celestina. Actas del congreso internacional, Universidad de Navarra, junio, 2001. Eds. Ignacio Arellano and Jesús M. Usunáriz Madrid: Iberoamericana/Vervuert, 2003: 211-236.

Gonzalo de Alba. "Libro sinodal." (1410). Synodicon Hispanum. Cuidad Rodrigo, Salamanca y Zamora IV. Eds. Antonio Garcia y Garcia et al. Salamanca: Biblioteca de Autores cristianos, 1987: 48-293.

Goodrich, Peter. "Legal Enigmas - Antonio de Nebrija, The Da Vinci Code and the Emendation of Law." Oxford Journal of Legal Studies 30.1 (2010): 71-99.

Guiance, Ariel. "Iglesia e ideología de la violencia en la Castilla medieval. Crímenes e infanticidios en la legislación canónica." Mediaevistik 12 (1999): 209-227.

Iglesias, Yolanda. "Implicaciones legales de las seis muertes en La Celestina: Un acercamiento histórico-literario." Romance Quarterly 62.2 (2015): 59-70.

Infantes, Victor. "Los libros 'traydos y viejos y algunos rotos' que tuvo el Bachiller Fernando de Rojas, nombrado autor de la obra llamada Celestina." Bulletin Hispanique 100.1 (1998): 7-51.

Jonsen, Albert R./Toulmin, Stephen. The Abuse of Casuistry. A History of Moral Reasoning. Berkeley/Los Angeles/London: California University Press, 1988.

Justo Fernández, Jaime. "Los libros en los sínodos medievales de la península ibérica." Revista Española de Derecho Canónico 71.176 (2014): 165-207.

Kallendorf, Hilaire. Conscience on Stage. The Comedia as Casuistry in Early Modern Spain. Toronto: University Press, 2007.

Lacarra Lanz, Eukene. "La muerte irredenta de Melibea." Proceedings of the International Symposium 1502-2002: Five Hundred Years of Fernando de Rojas' "Tragicomedia de Calisto y Melibea" (18-19 October 2002, Department of Spanish and Portuguese, 
Indiana University, Bloomington). Ed. and introd. Juan Carlos Conde. New York: Hispanic Seminary of Medieval Studies, 2007: 173-208.

Lacarra Lanz, Eukene. "Los Amores citadinos de Calisto y Melibea." Celestinesca 25.1-2 (2001): 83-100.

Möller, Ernst von. "Die Augenbinde der Justitia." Zeitschrift für christliche Kunst. XVIII. 4. (Düsseldorf 1905): coll. 107-122, 141-152.

O'Banion, Patrick J. “'A Priest who Appears Good': Manuals of Confession and the Construction of Clerical Identity in Early Modern Spain." Nederlands archif voor kerkgeschiedenis/Dutch Review of Church History 85 (2005): 333-348.

Panofsky, Erwin. Studies in Iconology: Humanistic Themes in the Art of the Renaissance. Chicago: University Press, 1982.

Paolini, Devid. "Un manuscrito desconocido del 'Tratado de cómo al hombre es necesario amar' (Ms.18665 de la BNE)." eHumanista 11 (2008): 65-80.

Prosperi, Adriano. Justice Blindfolded: The Historical Course of an Image. Leiden: Brill, 2018.

Rojas, Fernando de. La Celestina. Tragicomedia de Calisto y Melibea. Eds. Francisco J. Lobera, Guillermo Serés, Paloma Díaz-Mas, Carlos Mota, Iñigo Ruiz Arzalluz and Francisco Rico. Madrid: Real Academia Española, 2011.

Rove, Nina. The Jew, the Cathedral and the Medieval City: Synagoga and Ecclesia in the Thirteenth Century. Cambridge, UK: University Press, 2011.

Ruiz-Capillas, Jusdado. "Ius Commune y Common Law." Cuadernos de Historia del Derecho 15 (2008): 327-344.

Sánchez Herrero, José. "La Literatura catequética en la Península Ibérica 1236-1553." En la Espana medieval 5. Madrid: Editorial de la Universidad Complutense, 1986: $1051-1118$.

Saquero Súarez-Somonte, Pilar/González Rolán, Tomás. "Las Questiones sobre los dioses de los gentiles del Tostado: un documento importante sobre la presencia de Boccaccio en la literatura medieval española." Cuadernos de Filología Clásica XIX (1985): 85-114.

Serés, Guillermo. “La obra y los autores del la 'comedia' a la 'tragicomedia." La Celestina, 2011: 361-401.

Soto Rábanos, José María. "Visión y tratamiento del pecado en los manuales de confesión de la baja edad media hispana." Hispania Sacra 118 (2006): 411-447.

Tostado (Alfonso Fernández de Madrigal). Confessional. Valladolid: Diego Gumiel $15 \circ 3$. Weis, Adolf. “Die 'Synagoga' am Münster zu Strassburg.” Das Münster 1 (1947): 65-80.

Weiss, Tzahi. "Who Is a Beautiful Maiden without Eyes? The Metamorphosis of a Zohar Midrashic Image from a Christian Allegory to a Kabbalistic Metaphor." The Journal of Religion 93.1 (2013): 6o-76. 


\title{
Artful Rhetoric: The Case of Lázaro de Tormes
}

\author{
Edward H. Friedman
}

\begin{abstract}
The anonymous Lazarillo de Tormes (1554), the first of the archetypal Spanish picaresque narratives, is a fictional autobiography in the form of a defense. A figure known as "Your Grace" has asked the adult Lázaro to explain "the case" (el caso), a public scandal. The narrator starts the presentation with his humble birth. The explanation is replete with satire and irony. Its complex rhetorical structure points to the lack of mobility in the hierarchical society of the time and place.
\end{abstract}

\section{Keywords}

Lazarillo de Tormes - picaresque - "the case" (el caso) - defense - irony - social satire

Despite its early date of publication (1554), its comparative brevity, and its precocious entry into the realm of narrative realism, the anonymous La vida de Lazarillo de Tormes y de sus fortunas y adversidades is an exceptionally - and perhaps deceptively - complex work. Lazarillo de Tormes is a sophisticated text on a number of levels. First and foremost, it offers an intricate rhetorical display, posing questions that require answers and answers that may be more open to interpretation than resolved unequivocally. There is a plan to the narrative, but the plan simultaneously presents arguments and counterarguments that intersect, or clash. The narrator is an adult who begins the story at his birth and deals with his childhood experiences, thereby inserting Lázaro and Lazarillo into the frame. Furthermore, a pronounced, if figurative, voice-over intrudes on the narration and on its particular rhetoric. Two dispositions seem to coalesce, one individual and the other comprehensive, one geared toward a narratee and the other geared toward readers, who bring their own literary and experiential baggage into the act of analysis. The breadth of the intertext of Lazarillo de Tormes complicates the proceedings in productive ways, as does the distinction between the genre of autobiography and the creation of pseudo-autobiography, which adds a new dimension to the structure. The arrangement of the material is highly significant. The operational scheme begins in the short but fundamental prologue, in which the narrative 
voice jointly addresses the author's circumstances and delineates the narrator/ protagonist's pretext. What may appear to be - and has been perceived as loosely connected, episodic, and random is carefully and skillfully fashioned to form a profound, ingenious, and unified narrative, an aesthetic object and a social document, with strong ties to the past, as inscribed into a pioneering and forward-looking design.

Lazarillo de Tormes is, among other things, a challenge to literary romance, namely, to the idealism of sentimental, pastoral, and chivalric narratives. Its satirical thrust evokes spiritual autobiographies and confessions, as well as the autobiographies of exemplary figures. As with Don Quijote some fifty years later, satire and parody are means to ends rather than ends in themselves; and, again as with Don Quijote, realism is complemented by metafiction, by self-referentiality and a self-consciousness of the writing process per se. Correspondingly, intertextuality is a key ingredient in the composition of Lazarillo de Tormes and Don Quijote. Imitation becomes far less a sincere form of flattery than a mechanism for rewriting, reshaping, and reinventing narrative technique. ${ }^{1}$ Lazarillo de Tormes recasts the hero as antihero, or picaro. Lofty achievements are transformed into tales from society's underside, but exhibiting the accoutrements of idealistic models. Romance is turned upside-down through an imaginative reordering, or recontextualization, of conventions. The stance of the narrator/protagonist, in the text and in society, distances him from his illustrious predecessors and removes him from the exalted space that they may occupy. Any deep structural bonds with romance are negated by the status, comportment, and reception of the picaro by his fellow citizens. Autobiography, by its nature, will provide at least two narratives, based on real events and on rewriting or selective memory. Some type of reformulation will affect what Hayden White classifies as the emplotment, or configuration, of a life story, given that truth is more often relative than absolute (esp. $83 \mathrm{ff}$.). A fictional autobiography expands the template to include a writer detached from the subject and situated in a mediating site. The narrator's contact with the narratee and the writer's contact with the reader lead to different story lines and, likely, to different, and possibly conflicting, conclusions. Story and discourse converge - enter into dialogue, as it were - as storytelling is clearly incorporated into the narrative layout. The dual, and frequently dueling, communications establish the rhetorical foundation of the richly encoded narrative and its dialectical sense of perspective.

1 For a discussion of the casuistry of literary imitation as it relates to the work that, building on Lazarillo de Tormes, solidified the notion of the picaresque genre, see David Álvarez Roblin's essay on Guzmán de Alfarache, in this volume. 
At this point it should be clear that Lazarillo de Tormes engages with the central concerns of casuistry: the virtuoso use of rhetoric to interrogate and explain confounding circumstances; the "problematizing" of exemplarity by representing a life story that is not an ideal model for imitation (to say the least), nor a clear expression of escarmiento, or negative moral precept; the cultivation of a subjectivity not only in "split psyche" of the protagonist-narrator, but also in the reader, who is more challenged by questions than instructed with answers; the experience of constructing meaning that is provisional and contingent rather than definitive (see the introduction to this volume). And, as we shall now consider in some detail, all of this is brought to bear on the elucidation of a particular "case."

The prologue to Lazarillo de Tormes is concise but hardly easy to decipher. The first-person account commences with an author who directs his words to a potential readership that he wants to please and entertain. He cites Pliny the Younger's dictum that there is no book so bad that it has no redeeming features. Even the most modest accomplishment can have some value. He then quotes Cicero, noting that writing can be a source of honor. Everyone desires praise, from the soldier to the priest. The holiest of those among us may be interested in saving souls, but they also are gratified when their parishioners laud their oratorical gifts. People revel in praise, whether it be merited or not. The author refers to his manuscript as a trifle (nonada), the story of a man no better than his neighbors, written in an unrefined manner, yet bearing the imprint of one who has endured misfortune, danger, and adversity. It is a story suitable of being told for that reason alone. Having justified his enterprise, the author cedes to the narrator/protagonist, who speaks to a narratee, Your Grace (Vuestra Merced), who has written to him to request a thorough explanation of "the case" (el caso). Contemplating the mandate, the narrator has chosen to start at the beginning, as opposed to in medias res, so that he will not have to omit relevant information. He makes the point that the triumphs of those who have assumed hardships from birth onward should not be measured according to the same criteria by which those on whom Fortune has smiled are judged. Success is a function of one's condition, milieu, and station in life. Those born of wealth and privilege must be considered separately. Those who have beaten the odds deserve credit for their fortitude, perseverance, stamina, and survival strategies; they are, quite literally, in a class by themselves.

The decidedly succinct prologue conveys a double focus and examples of doubling that will remain in effect throughout the narrative. The teller of the tale is, at once, an author cognizant of his readers and a mature narrator/ protagonist mindful of his obligation to Vuestra Merced, whose exact identity is unknown but who can be seen as an authority figure of some sort. While 
Lázaro de Tormes has been educated in the so-called school of hard knocks, the author is familiar with Pliny and Cicero. The prologue moves from the broad plane of fictional writing and reception to the immediate predicament of the central character. Not only is there vagueness with respect to Vuestra Merced, but the specifics of the "case" are likewise elusive. Nonetheless, a discursive maneuver is already in place. Lázaro will emphasize his humble origins in order to accentuate his determination and resilience, notwithstanding the obstacles that have faced him from his youth. The stimulus here is the demand for an elucidation of the case, and the response is a self-defense built around the transcendence of negative forces by a disadvantaged soul. Bloodlines and social rank will lie behind the defensive stratagem of a man in need of the sympathy of his arbiter. The prologue to Lazarillo de Tormes puts forth the dilemma of the protagonist and conspicuously signals a blueprint for the rationale that will follow. The precise parameters of the case and the identity of Vuestra Merced are mysteries. As will be seen in the prologue to Part 1 of Don Quijote, the fiction has now begun. This will not be a traditional autobiography in form or content. Lázaro de Tormes will juxtapose the requisite explanation of the case with a description of the hurdles over which he has prevailed - from birth to maturity - and he will mix the duty to comply with the inquiry and the goal of self-protection. Hence, the narrative will reflect a juggling act between the two objectives amid other series of binary oppositions: Lázaro and Lazarillo, the narratee and the reader, the past and the present, truth and poetic license, and, to be sure, narrative reliability and the abstract presence of what Wayne C. Booth terms, in The Rhetoric of Fiction, the implied author. ${ }^{2}$

In short, Lázaro's discourse is always mediated; never is a self-contained story recounted. The narration is multi-layered, with shifting weight, impact, implication, and consequence. The prologue may induce the reader to examine how the narrative is organized and how it transmits messages. The inner story will expose Lázaro's attempt to control the discourse and, certainly to some readers, it will reveal the matching and overriding intention of the author. Lázaro replies to Vuestra Merced in a calculated method of narration, aimed to distract from the issue at hand in favor of the chronicle of a social ascent, albeit moderate. Lázaro hopes to vindicate himself. The creator of his discourse may have contrasting ideas and contradictory motives. The construct of the implied author depends on the recognition of a competing discourse and a competing voice that is conjectural and hypothetical and yet overshadows and

2 For commentary on the implied author, see Friedman, The Antiheroine's Voice $16 \mathrm{ff}$. and Cervantes in the Middle $40 \mathrm{ff}$. 
supersedes the concrete sign systems of the narrator. Lázaro's narrative is both wide-ranging and concentrated. The boy who seems to be doomed to failure suffers numerous calamities and tribulations, but he carries on, refusing to give up, refusing to be defeated. In the end, he has made something of himself. He categorizes his vocation as respectable. His explanation of the case rests on an apparent evasion of the damaging aspects of the state of affairs and a highlighting of advancement in society. Lázaro's autobiographical impulse allows him to divert attention from facts that could be detrimental to a self-serving posture, as the narrator converts a personal quandary into a success story. The link between story and discourse is rhetoric. Lázaro initiates his remarks by observing that society's dispossessed warrant extra consideration for their attainments, no matter how meager they may be, under oppressive protocols and the constant scrutiny of their superiors. Rhetoric is, after all, the art of persuasion, and Lázaro endeavors to convince Vuestra Merced of his worth as a citizen. The proposal is logical, if a bit convoluted. Its execution is rendered more elaborate by the intervention of a rival voice.

Lázaro writes his defense with a plan in mind. He conceives a cautious and deliberate path to apprise Vuestra Merced of his rites of passage and his role in society. Structure and content are conspicuously interdependent. Lázaro's mode of presentation touches a range of intertextual elements, literary and nonliterary. The degree of irony that encompasses this exercise is astonishing, and more so when the intercession of the implied author attaches to the narrative scenario. Irony is the guiding trope of the text and a major facet of its dialogical intensity. Irony is the mark - and the marker - of the implied author. Lazarillo de Tormes takes point of view to extremes, and that is one of its strengths. The progression of the plot depicts the stages of the protagonist's development, but it may be the interplay of perspectives that most patently animates the narrative and engages the reader. Vuestra Merced obviously knows much about Lázaro de Tormes. The author seems to expect readers to have a command of the intertext, since satire and parody cannot exist in a vacuum. In the middle position, the implied author forges a semiotics of perception. That is, the author has to trust the reader to discern, acknowledge, and comprehend the signs, the clues to the multi-tiered structure of the narrative. The author invites the consumer of literature to read between the lines. The embedded signs within the narrative can be seen as the input of the author, whose presence in the text is implicit. In the prologue to Part 1 of Don Quijote, Cervantes casts a fictionalized version of himself as narrator, and this persona, who could be designated as "Cervantes," converses with a "friend," the alter ego of an alter ego. The discussion of the precepts for the writing of prologues occupies much of the prologue, or, in essence, the metaprologue. The friend 
advises "Cervantes" to ignore the customary rules for composing a prologue with quotations from venerated sources - by filling in the allotted space with anything that strikes his fancy. The prologue inaugurates the fictional venture, with allusions to the targeted destruction of the romances of chivalry, but with an air of subversion, a confrontation with authority in and beyond literary norms. Cervantes is the historical author, outside the text. "Cervantes" and the friend are characters inside the text. The instigator of theoretical subversion and the purveyor of alternative and ironic signs is the implied author, whose presence is insubstantial, felt rather than embodied. Lazarillo de Tormes anticipates this set of narrative relations.

In reading the text, one must bear in mind the questions of the identity of Vuestra Merced and the subject of the "case" while speculating on the cohesiveness of Lázaro's argument and defensive strategies, as introduced in the prologue. The reader may analyze the narrator's structuring of his story: the division into chapters (tratados, literally treatises), the primary content of each chapter, the frames, the varying lengths of the chapters, the motif of hunger, the search for a proper identity, the transitions, and the turning points. There are crucial dialectics at play: the indicators of Lázaro's objectives and statements that would seem to interfere with these objectives, reversals of what would seem to be Lázaro's intentions, crossings of a defense with a success story, propositions that appear to support Lázaro's reasoning and those that refute his contentions, and so forth. The reader can assess, sequentially, the steps of the narrator's self-defense and the segments of his argumentation, together with evidence of an ironic counter-discourse in the exposition. On occasion, Lázaro may go off-topic, and these digressions can hint at ulterior motives. His compliance with Vuestra Merced's request for an explanation of the case takes an intertextual route, influenced by autobiography, confessional literature, popular culture, the Bible, romance, idealism in general, and the Italian novella and incipient realism. Lazarillo de Tormes is distinguished by an overwriting or rewriting of the story by the implied author, an abstraction with a contrary agenda and an ironic bent. In the expansive and fluctuating center of the text stand literature, society, and the status of the individual, ripe for evaluation and reevaluation. ${ }^{3}$

3 The intertext of Lazarillo de Tormes naturally includes the extensive critical bibliography on the text. I would like to note six essays that have informed my comments here. I have learned from these scholars (and many others), and I have bounced my ideas off of theirs: Frank Casa, Alfonso J. García Osuna, David Gitlitz, Rosa Navarro Durán, George A. Shipley, and Carolyn Wolfenzon. I am indebted to them and to their professional colleagues who have guided me over the years. I have included among the Works Cited a selection of my previous essays on Lazarillo de Tormes. 
In Lazarillo de Tormes, the deep structure of idealism aids the cause of realism. Tratado 1 opens with the protagonist's genealogy, the antithesis of a noble pedigree or the celebrated lineage of a knight errant. Lázaro's father was in charge of a mill on the river Tormes, where his wife visited just before she went into labor. Lazarillo de Tormes may resemble Amadís de Gaula or Belianís de Grecia as an appellation but not as a gauge of notability. When Lazarillo is eight years old, his father is accused of theft and imprisoned. The former miller is permitted to enlist in an expedition against the Muslim enemy as muleteer for a gentleman soldier, and he loses his life in combat. He can be praised for his service to the faith, but he is a criminal who leaves his widow in dire straits. Lázaro's impoverished mother strives to better her lot by, as the proverb says, aligning herself with the good people in order to become one of them ("arrimarse a los buenos por ser uno dellos" [10]). ${ }^{4}$ She moves to Salamanca, where she finds work as a cook and washerwoman for stableboys. She becomes attached to Zaide, a dark-skinned man, who brings her food and often spends the night. Lazarillo soon has a baby brother, who is frightened of the looks of his father, calling him a bogeyman. Lázaro comments in an aside that, in spite of his tender age, he was able to grasp that people do not see in themselves what they run away from in others. Like the deceased father, Zaide is a thief, and he makes Lazarillo's mother his accomplice. The officers of justice are suspicious, and they corner and threaten Lazarillo, who out of fear for his own welfare blurts out what he knows. Zaide is apprehended, and he and Lazarillo's mother are severely punished for their offenses. The beleaguered woman tries to make amends. Attentive to her two sons, she toils as a servant at an inn, where Lazarillo runs errands for the clientele. Beset by poverty and a bad reputation, she elects to confer the guardianship of Lazarillo to a blind man who is staying at the inn, advising him that the boy is the son of a good man who died while waging war against the foes of Christianity. The blind man agrees to receive Lazarillo as a son; he maintains that each in his own way will guide the other.

Lázaro portrays his time with the blind man as a period of profound learning, a period of disillusionment (desengaño) in which he loses his innocence. It is he who is blind to reality and his master who sees through the boy's tricks involving a linen sack, a wine bottle, a bunch of grapes, and a sausage. The episode of the blind man institutes the motif of hunger whereby Lazarillo must fight for his very survival. The blind man has vowed to instruct his charge as a father might instruct a son, but he comes close to starving the boy as he mocks and ridicules him before any onlookers who happen to be nearby. Lazarillo

4 All quotations from Lazarillo de Tormes will refer to the Rico edition. 
absorbs from his master the art of winning people over with charm, wellpracticed sincerity, and ruses to earn compassion. Among the insights is an understanding of sight itself. Lazarillo escapes from the blind man by reversing the roles; his master has taught him not to be blind to his surroundings, and the boy uses his visual aptitude to devise an opportunity for flight. In this rendition of the story, the victim outsmarts the victimizer, who has trained him to do so. The ironic twist coordinates with other ironies. The observation of his little brother's reaction to his father will later relate to Lázaro himself, and so will his inability to keep silent about Zaide when intimidated by the law enforcement agents. Blindness and silence, real and figurative, help to determine Lázaro's fate at the beginning and the end of his narrative. The written testimony will unmask - and undermine - his tactics and his fabrications. The first chapter of the defense has Lázaro describing his heritage, the background and destinies of his parents and stepfather, and his ordeal with the first of his masters. The inversion of romance formulas and the angle of vision from the depths of society deflate the paradigms of idealistic fiction. Lázaro stresses his lowly origins to let Vuestra Merced appreciate his lack of options, his vulnerability, and his deprivations. Lázaro's rhetorical strategy interacts with the power of satire and with an ironic structure that will continue and will grow exponentially as the narrative proceeds. The narrator's words, in sum, may not be self-protective, nor will his control of the discourse be conclusive or freestanding. By the same token, a portion of the ironic machinations targets society at large, to be dissected at the time of composition and thereafter.

Having left the blind man, Lazarillo finds employment with a miserly priest who intensifies the concentration on hunger. The precariousness of the boy's existence has gone from bad to worse, for his new master is sighted, vigilant, and exaggeratedly parsimonious. To his shame, Lazarillo is reduced to praying that parishioners meet their maker so as to satisfy his appetite at their funerals and wakes. Aided by a tinker who makes him a key, he steals morsels of bread from the priest's locked chest, which becomes his "breadly paradise" ("paraíso panal" [33]). He attributes the thefts to a mouse and finally to a snake. The priest is beside himself. Protecting the key by keeping it in his mouth as he sleeps, Lazarillo inadvertently emits a sound that rouses his master, who discovers the hoax, bashes his servant in the head, and dismisses him. Breaking a silence has again had a painful outcome. From the perspective of Lázaro, the second tratado demonstrates how he leaps from the frying pan into the fire. Hunger moves him to near-starvation. His ingenuity is put more relentlessly to the test by a callous, unfeeling, and watchful master dedicated to safeguarding the chest at all costs. This is a master who encroaches on what little 
privacy that Lazarillo retains and who incessantly can hover over him. Lázaro foresees a question from Vuestra Merced as to why he did not run away from this wretched situation; and he responds that he was afraid that, in light of his record to date, he might fare even more poorly with a third master. For the anxious boy, the next rung on this unsteady ladder could be death. He stays with the priest until he is ejected in disgrace. His hunger will persist.

Tratado 2 traces Lazarillo's mounting isolation and sense of solitude. The chapter concerns the picaro's encounter with a representative of the Church, who proclaims his magnanimity as he feeds the boy mere crumbs and gravy with no meat. That the priest is adept at hypocrisy - in word and action scarcely seems coincidental, and he is but one of an array of ecclesiastical figures in the text. The episode is filled with images associated with rituals and the daily routine of the cleric, from charitable donations to the collection box, from officiating at services to ministering to the infirm and needy, with food and remuneration as common themes. In this instance, faith is compromised, debased. The ramifications are more damaging and more derogatory than Lazarillo's desperate efforts to stay alive. Interestingly, Lázaro's discourse in this chapter is replete with religious vocabulary and references to prayer, confession, God's pardoning gestures, miracles, Saint James, saying grace and saving grace, the devil, and more. Lázaro prolongs his enumeration of ills, and the narrative - be it wittingly or unwittingly - illuminates the complicity of society, and of its most sacred institutions, in the behavior and transgressions of its outcasts.

After his banishment from the priest's quarters, Lazarillo, in distress, makes his way to Toledo, where he accepts handouts while his wounds heal. Those he meets warn him that he must look out for himself. He chances upon a man who is well dressed and looks prosperous. Fortuitously, or so it would seem, the gentleman asks if the boy is looking for a job. When Lazarillo answers in the affirmative, the man declares that this must be his lucky day. The boy informs his new master of his personal history, underscoring only the good points; that is, he lies - a habit, Lázaro admits to the narratee, at which he is proficient. Lazarillo's initial exhilaration is quickly crushed, as disillusion once more rears its ugly face. The gentleman is a squire, but he currently is disenfranchised from the benefits of class, and his aura of affluence is a façade. His outward appearance is imposing, but there is nothing on the inside. His home is dark and bleak, with, at most, a paltry supply of food. The liquid refreshment is water, not wine. Lazarillo shares his leftover bread with the penniless squire, and he will later hunt for - and beg for - provisions for the two of them. The chapter illustrates Lazarillo's plight. He must prevent himself and his master 
from dying of starvation, at a time in which statutes against beggars escalate. The squire is not malevolent or merciless, but excessively proud. He is devoted to and trapped by the code of honor, which precludes manual labor for a person of his rank. He risks public humiliation for his penury because his top priority is his reputation, his honorability. Adherence to the prescribed regulations is immutable and nonnegotiable. Lázaro relates the squire's exhaustive story of his unswerving allegiance to the code of honor and the repercussions of this obsession, which the boy ascribes to vanity. Although he is kind to Lazarillo, the squire jeopardizes the safety of his servant. A benevolent employer does not alter the operative motif of hunger rekindled and exacerbated from one master to his successor. When creditors pursue the squire, he runs away, leaving Lazarillo destitute and on his own. The young boy is exonerated when neighbors testify on his behalf to the constable who has come to investigate. Lazarillo's wellbeing is bound to his master's commitment to the concept of honor, and Lázaro interpolates a social critique predicated on the fusion, or confusion, of reality and appearances. It is of considerable importance that he disapproves of the squire's compulsive attachment to a rigid code of conduct. The young boy and the mature adult pass judgment on the squire. Matters of honor will reenter the narrative at future junctures.

Lazarillo's fourth master is a Mercedarian friar for whom the monastery holds negligible appeal. The friar cannot stay put; he prefers to traipse around, and the boy must accompany him on his ramblings, entailing visits of a more secular than spiritual orientation. As narrator of tratado 4, the briefest of the chapters, Lázaro seems to want to disclose few particulars, yet the breaking of silence is again notable. He does mention that the friar gave him the first pair of shoes that he wore out, in only a week. The rapid pace is too much for Lazarillo, who takes his leave, noting famously, "for that reason and for other little things that I will not speak of" "por eso y por otras cosillas que no digo" [67]). The language is suggestive. The pronouncement of the elimination of details could lead one to think the worst, about the friar and possibly about the impressionable boy. The chapter is a segment of the narrative, left open, but intended, within one plan or another - or within more than one plan - to be interpreted, to fill in gaps.

Tratado 5 tells of Lazarillo's service to a pardoner, a seller of papal indulgences who manages the responsibility honestly if he can and dishonestly if he cannot. Vital to this chapter is Lazarillo's role as a witness to the activities of the pardoner. The report is narrated from the boy's point of view as he comes to understand the artifice and the modus operandi of his master. When sales are at a standstill, the pardoner enlists the assistance of accomplices and 
contrives "miracles" so as to sustain an atmosphere of wonderment and to inspire purchases. When the pardoner realizes that Lazarillo is aware of his scams, he admonishes the boy to stay mum. Lazarillo decides that this would be to his advantage, and he remains silent (until now). Lázaro comments that even as a lad he was able to see the ease by which swindlers can manipulate the innocent and the naïve; he himself was not wise to the fraudulent ploys. There seems to be a touch of admiration in this reflection. Lazarillo is, for the most part, absent from the plot of this chapter. He is a spectator of the metatheater of the pardoner, another of the instructors in this rudimentary program of education. Lazarillo's figural disappearance in the fifth chapter heralds a transition. Life is not uncomplicated, but hunger is no longer a problem. The boy is growing up. Raymond Willis, in "Lazarillo and the Pardoner," proposes that the fifth tratado lets the author take the protagonist from boyhood through adolescence to young adulthood in the sixth tratado, which segues into the seventh and final tratado, wherein Lázaro has a legitimate profession and a wife.

In the sixth chapter, Lázaro writes of his job mixing colors for a painter of tambourines. He describes the job as harsh - "sufrí mil males" ("I suffered a thousand ills" [75]) - without further elaboration. He labels himself a mozuelo, a young man on the move. Opportunity knocks. A chaplain gives Lázaro a more agreeable position as a water seller and furnishes him with a donkey, four jugs, and a whip to perform his chores. He pays the chaplain a commission and earns an adequate income. After four years in the trade, Lázaro can afford to purchase, by his standards, upscale clothing, the articles of which he takes care to itemize: a well-worn fustian jacket, a coat that has seen better days, and a cloak that is lacking its original fringe border, along with an old-fashioned sword. Dressed to the nines in his second-hand garments, Lázaro feels that the job of selling water is beneath him. He returns the donkey to the chaplain and, with an upward glance, he embarks on a new path. In tratado 6, Lázaro may overstate the elegance of his new wardrobe, but he is documenting another phase of his rise in society. He is nearly self-sufficient, and he backs away from menial labor. He wants to move forward, and when he looks in the mirror at his well-clad image, he envisions a better life, one of prosperity and inclusion. It would be difficult not to notice that Lázaro's recent acquisitions parallel those of this third master, the square: un jubón, un sayo, una capa, una espada. Lázaro has condemned the squire's inordinate pride and obsession with honor, yet, consciously or unconsciously, he emulates his former master, with striking emblems that connect the two. To an extent, the seventh tratado is constructed around the theme of honor. Lázaro's response to Vuestra Merced - his explanation of the case - is attendant on the stand of each apropos of what constitutes 
the honor of an individual and which individuals are entitled to be integrated into the framework of honor.

The time spent under the supervision of the chaplain is by far the longest period with a master. When he departs, Lázaro is an adult, confident and primed to participate in mainstream society. He finds work with a constable, a symbol of law and order, but the perils outweigh the prestige. When a group of fugitives attack and wound the constable, Lázaro reneges on his agreement and looks for a safer occupation. In search of an appropriate long-term position and eager to improve his lot (medrar), he succeeds in obtaining "un oficio real" (77), a civil service appointment that, stretching the point, could be regarded as a bare-bones "royal office." He is a town-crier, tasked with announcing wines for sale, merchandise on the market, auctions, and lost articles, and he must join the convoy of prisoners charged with crimes so that he can shout out their alleged misdeeds. Very little happens in Toledo that does not reach the eyes and ears of Lázaro de Tormes, who boasts that he has his hands - or, more accurately, his mouth - in almost all affairs in the city. Overwhelmed by his good fortune, Lázaro expresses gratitude to the friends and sponsors who have encouraged and guided him. Above all, he thanks God for answering his prayers and Vuestra Merced for being his advocate. He notes that at the time of writing he still has the position and is still deeply beholden to God and Vuestra Merced. He seems to be getting closer and closer to explaining "the case."

Lázaro receives the patronage of the Archpriest of San Salvador, who is grateful for the enthusiasm and resourcefulness that the town-crier puts into publicizing his wines. Lázaro refers to the archpriest as "my master" and says he is "at the service of and friend to Vuestra Merced." The archpriest is so fond of Lázaro that he offers to set up a marriage between his employee and one of his maids. Lázaro sees no wisdom in rejecting the gracious proposal, which could only strengthen the relationship with his mentor. The marriage is celebrated, and Lázaro sings the praises of his wife, who is diligent and accommodating, and of the archpriest, who attends to the couple and bestows food, cast-off clothing, and other gifts on them. The archpriest invites them to dine with him on Sundays and holidays, and he locates a home near his own for them to rent. This harmonious lifestyle is disrupted by malicious gossip from neighbors who assert that Lázaro's wife goes to the archpriest's residence to cook his meals and make his bed, spending extra hours that leave her open to suspicion. Lázaro admits that this is true, but he wants to curb the rumors in order to preserve the sanctity of his marriage and the backing of the archpriest. His wife does not take the public airing of her labors lightly. Lázaro recalls the words of the archpriest, uttered in the presence of his wife, to the effect that 
nothing untoward goes on when she is working in his home, and that Lázaro should pay no mind to the wagging tongues, but instead to his best interests. Lázaro wholeheartedly endorses the recommendation, indicating that he has pledged unwaveringly to align himself with the good people. He concedes, nevertheless, and before the woman in question, that friends have verified to him that his wife had given birth three times prior to their wedding. The woman becomes enraged; she cries, and then vigorously screams and curses at the man who arranged the marriage. Lázaro instantly regrets his words, and he is so upset that he says he wanted to die on the spot. With some pain on all sides, the two men calm the despondent woman, assuring her that from now on her faithfulness will not be interrogated. Lázaro promises never to broach the topic of how she fulfils her duties; his wife's right to enter the archpriest's quarters and to stay for as long as she pleases will be inviolable. Each of the three is satisfied with the outcome.

Lázaro punctuates his outlook by quoting himself in response to those that he senses are about to disparage his wife. He denounces those who would put her and the marriage in harm's way. He cautions his friends against gossipmongering, against spreading any tales that would cause friction between him and his spouse, whom he values more than anything else in the world. God has granted him domestic bliss, more than he deserves. He is willing to swear "on the consecrated host that she is as good as any woman living within the gates of Toledo" ("sobre la hostia consagrada que es tan buena mujer como vive dentro de las puertas de Toledo" [8o]) - an intense statement open to double meaning - and he is prepared to kill anyone who says otherwise. His neighbors take the warning seriously, and there is peace in his home. Lázaro concludes by recording that this culminating incident has occurred at the moment in which the glorious emperor Carlos I has entered Toledo to hold parliament, and he adds that "at this time I was living in prosperity and at the height of all good fortune" ("en este tiempo estaba en mi prosperidad y en la cumbre de toda buena fortuna" [80]). Conflict seems to have been resolved and order restored. In Lázaro's estimation, the archpriest has no qualms. Lázaro's wife can come and go as she wishes. Lázaro's fellow citizens have respected his plea for silence. The case is closed. Or is it?

At the end, the enigmatic elements of the prologue remain in force. Vuestra Merced is an authority figure. The seventh tratado alludes to his association with the archpriest, but the gentleman's specific identity is not clarified. The "case" that requires an explanation probably is a supposed scandal emanating from the service of Lázaro's wife to the archpriest. Lázaro insists that the dispute has been settled, but nothing else in the narrative would seem to qualify 
as the "case." The explanation exonerates the three parties - husband, wife, and employer - and stresses closure. Social, professional, and personal prosperity leads to the happy ending. Lázaro's rhetorical strategy, initiated in the prologue, is corroborated in the narrative proper. The explanation is a success story, a victory over unceasing hurdles and barriers, from a vulnerable child facing starvation to a man seeking a decent place in a society poised to shun him. The trials of his youth lead Lázaro to a position of trust and the support of - and dependence on - eminent benefactors. There is a pervasive sense that something is missing. There may also be a feeling that Lázaro is not in full control of the discourse. The picaro's commentary is not consistently favorable to his self-defense, and his struggle for upward mobility cannot avoid the proscriptions of social policies. Lázaro's narration vies with a formidable counter-discourse grounded in irony. The imagery and the circumstances have circular patterns. The widowed mother goes to Salamanca to band with - arrimarse $a$ - the good people, and her troubles multiply. Lázaro repeats the adage when he speaks of his move to Toledo. The most extended motifs relate to the dichotomies silence/speech and blindness/sight. From his childhood days, as in the revelation of Zaide's thefts and the "otras cosillas que no digo" about the escapades of the friar, to the admonition to his friends in Toledo, among other examples, Lázaro breaks protective silence and in so doing incriminates others - and himself. Similarly, the play with vision and blindness with the first master continues to the end, when Lázaro chooses to close his eyes to the goings-on at the archpriest's residence. He pushes an agenda of composure and serenity by trying to expunge, if not always credibly, any tinge of discord.

When the narrator/protagonist's words work against him - against his explanation of the case - the implied author would seem to intervene and to heighten the irony. The parody of literary idealism and the ensuing distortion of the intertext are interposed with social realities as Lázaro becomes increasingly distanced from the center of message production. His comments and judgments reverberate against him as the narrative progresses. Lázaro (and Lazarillo) will pause to criticize the squire's obsession with the honor code, but the "case" - the motivating factor of the narrative - may hinge on the husband's preoccupation with appearances and respectability. Lázaro can relish the creature comforts that eluded him as a boy, but the very practices that he has derided in the past shape his thoughts and actions. The purchase of apparel in the sixth tratado is a harbinger of the change of attitude. Lázaro dissociates himself from a fixation with the tenets of the honor code and then contradicts himself by clinging to its principles, so that the world can see him as worthy of the social standing that he professes to enjoy. The stance is ironic, for if Lázaro genuinely has subscribed to the honor code, his tranquility will be 
unremittingly under siege. For true believers, this would be worse than starvation, worse than death. If he is not truthful, he forfeits the clout that he claims to have; he will forever be an underling, and his success story rings false. In the closing paragraph, Lázaro links his narrative to the arrival of the emperor in Toledo. He may be striving for similitude, but the result is radical difference. The text reexamines the scope and the stumbling blocks of institutionalized honor. There may be threads of subversion, as there may be, as well, in the representation of religious characters whose hypocrisy surpasses their piety. In the process, the anonymous author redefines the perimeters of satire and the design of narrative, as Cervantes would do, sui generis, in Don Quijote.

Lazarillo de Tormes is about literature and about society. The author takes the appurtenances of idealistic fiction and exemplary autobiography and turns them inside out. The narrative starts at the bottom, not at the top, and the inversion is meaningful. Unlike the protagonists of romance, Lázaro is a product of literary and social determinism - a product of environment and heredity and he submits an account of his growth and development, physical and psychological. The satirical edge places the narrator/protagonist in an awkward, and untenable, position: his explanation of the case becomes self-parody. His own words do him in, and one may suspect that they are not his own words. Lázaro's objective is to demonstrate the overcoming of his unprepossessing origins and his subsequent rise in society, yet he is continually outvoiced by the abstract creator of an ironic subtext. Lázaro substitutes making his own case for explaining "the case," but the implied author conspires against him. Lázaro wants to elevate himself in the eyes of Vuestra Merced, but his plan may backfire as the narrative confirms his status as a perennial outsider. The inalterable position excludes the kind of honorability to which Lázaro aspires, and he moves from subject to object. Conversely, and ironically, the satirical trajectory gives him a principal, or the principal, role in the narrative, the equivalent of which society roundly denies him. The fictional project rescues - or, one might say, resurrects - Lázaro and those of his ilk from oblivion. Additionally, the vision of society is less than heroic, less than admirable. Among the paradoxes of irony is the mutability of reception. Views of the antihero and of the dynamics of the individual versus society are not bound by the reigning temperament of mid-sixteenth-century Spain. Ultimately, the text is open rather than closed, ambiguous rather than unambiguous, exhibiting a paradoxical consistency. It appeals to distinct, and varying, sensibilities. Whatever one's readerly inclinations, a persona can be identified behind the mask of fiction.

Lazarillo de Tormes can be deemed a case study. As if in a courtroom situation, Lázaro states his case, which takes the form of an explanation of "the case," offered to the petitioner, known only as Vuestra Merced. The 
prologue - addressed jointly to an imagined readership and to the narratee alludes, respectively, to entertainment and instruction and to compliance with the request. The macrocosm would seem to be the book and the microcosm the fictional account; that is, the text subsumes the pretext. The author and the implied author exert the highest degree of control, while the narrator/protagonist impeaches himself on a regular basis. There is a discernible correlation between Lázaro's role in the discourse and his role in society; the character does not govern his fate. This analogue becomes the foundation of the narrative. The brilliant and complex literary experiment is, at the same time, a social document, and each is contingent on the whims of fortune, circumstance, context, interpretation, and revisionism. The connection to jurisprudence is unmistakable, as is the connection to moral conscience. The satire never lacks seriousness of purpose. The mockery and deprecation of the lower classes may have been a source of humor, but mean-spiritedness can defeat itself in the long run; authoritarian ideologies tend to have limited lifespans. Sociologists of literature and contemporary readers are able to rethink and amplify the field of study, confronting precedents and proffering new hypotheses. Analysis is flexible, conditional, transitory. Lazarillo de Tormes is a uniquely evocative text. Its intricacies belie its date of publication. The narrative satirizes idealism as it validates realism through a novel and novelistic approach. The assessment of ethical points and, therein, issues of right and wrong are supremely indeterminate, prompting dialogue from many vantage points. Irony is the leading trope of Lazarillo de Tormes, and irony unfailingly yields to irony. The final irony - or, more accurately, the penultimate irony - of the narrative is that the predominant voice is that of Lázaro de Tormes, whose strains rise above the competing voices in a decentered center. He may lose "the case," but he wins the fight for survival and innovation.

\section{Works Cited}

Booth, Wayne C. The Rhetoric of Fiction. Chicago: University of Chicago Press, 1961.

Casa, Frank P. "In Defense of Lázaro de Tormes." Crítica Hispánica 19.1-2 (1997): 87-98. Cervantes, Miguel de. Don Quijote de la Mancha. Ed. Francisco Rico. 2 vols. Barcelona: Crítica, 1998.

Cervantes, Miguel de. Don Quixote. Transl. Edith Grossman. New York: Ecco, 2003.

Friedman, Edward H. The Antiheroine's Voice: Narrative Discourse and Transformations of the Picaresque. Columbia: University of Missouri Press, 1987.

Friedman, Edward H. Cervantes in the Middle: Realism and Reality in the Spanish Novel from Lazarillo de Tormes to Niebla. Newark, DE: Juan de la Cuesta, 2006. 
Friedman, Edward H. "Chaos Restored: Authorial Control and Ambiguity in Lazarillo de Tormes." Crítica Hispánica 3 (1981): 59-73.

Friedman, Edward H. "Coming to Terms with Lázaro's Prosperity: Framing Success in Lazarillo de Tormes." Crítica Hispánica 19.1-2 (1997): 41-56.

Friedman, Edward H. “'Cómo se hace un autor': Lazarillo de Tormes and the Rigors of Anonymity." Studies in Honor of Donald W. Bleznick. Eds. Delia V. Galván et al. Newark, DE: Juan de la Cuesta, 1995: 33-48.

Friedman, Edward H. "The Fortunes of Irony: A Metacritical Reading of Lazarillo de Tormes." Essays in Literature 15.2 (1988): 285-93.

Friedman, Edward H. "From the Inside Out: The Poetics of Lazarillo de Tormes." Philological Quarterly 89.1 (2010): 13-30.

Friedman, Edward H. “El pobre servicio de mano': Lazarillo de Tormes, Don Quixote, and the Design of the Novel." 1605-2005: Don Quixote across the Centuries. Ed. John P. Gabriele. Madrid and Frankfurt am Main: Iberoamericana/Vervuert, 2005: 29-50.

Friedman, Edward H. "Roads Untaken: The Spanish Picaresque Novel." A History of the Spanish Novel. Ed. J.A. Garrido Ardila. Oxford: Oxford University Press, 2015: 96-121.

García Osuna, Alfonso J. “Eros y Ágape en la voz de Lázaro de Tormes.” Hispanic Journal 33.1 (2012): 11-22.

Gitlitz, David. "Inquisition Confessions and Lazarillo de Tormes." Hispanic Review 68.1 (2000): 53-74.

Lazarillo de Tormes. In Novela picaresca española, I. Ed. Francisco Rico. Barcelona: Planeta, 1967: 1-8o.

Lazarillo de Tormes. In Two Spanish Picaresque Novels. Ed. and transl. Michael Alpert. Harmondsworth, Middlesex, England: Penguin Books, 1967: 21-79.

Navarro Durán, Rosa. "Dar la palabra al texto de La vida de Lazarillo de Tormes." Revista Canadiense de Estudios Hispánicos 41.1 (2016): 11-33.

Shipley, George A. "The Critic as Witness for the Prosecution: Making the Case against Lázaro de Tormes." PMLA 97.2 (1982): 179-94.

White, Hayden. "The Historical Text as Literary Artifact." Tropics of Discourse: Essays in Cultural Criticism. Baltimore: The Johns Hopkins University Press, 1978: 81-10o.

Willis, Raymond S. "Lazarillo and the Pardoner: The Artistic Necessity of the Fifth Tractado." Hispanic Review 27.3 (1959): 267-79.

Wolfenzon, Carolyn. "Unidad y fragmentacion en Lazarillo de Tormes." Hispanófila 149 (2007): 1-16. 


\title{
The Intrusion of an Apocryphal Guzmán as a (Legal, Moral and Literary) 'Case' in Mateo Alemán's Authentic Second Part
}

\author{
David Alvarez Roblin
}

\begin{abstract}
This article postulates that the publication of the apocryphal Second Part of Guzmán de Alfarache in 16o2 constitutes an unprecedented "case." Within the frame of the fiction, Mateo Alemán explores the different options available for resolving it and determining how to act: Does it constitute a theft or a challenge? Is it possible to mete out a just punishment to the perpetrator, or is revenge the only remedy? Is it an instance of plagiarism or artistic appropriation?
\end{abstract}

\section{Keywords}

Case - theft - challenge - punishment - revenge - plagiarism - artistic appropriation Guzmán - Alemán - Luján

When we discuss Guzmán de Alfarache and casuistry, we tend to focus our attention on the ending of the work, in which the picaro, who is a prisoner of a galley ship after his so-called 'conversion', is faced with a complex moral dilemma. He has to choose between two equally problematic solutions, both from the point of view of principles and their practical consequences: either to denounce the ship's group of conspirators, which would mean lying and condemning the rebels to a horrific death, or to betray the captain, the representative of the King on the galley ship, leading to the almost certain death of all of the crew. The case becomes even more complicated when we take into account that the protagonist has all of the motives to want to take revenge on both the captain and Soto, the conspirators' ringleader: the captain has had him whipped almost to death in a cruel and unjust manner, while Soto, who had been an intimate friend of his, has become his worst enemy. For all these reasons, whatever his final decision, Guzmán will find it difficult to free himself from being suspected of having acted out of revenge. Given the peculiarity of the context of his dilemma, it is hardly surprising that the ending of

(C) DAVID ALVAREZ ROBLIN, 2022 | DOI:10.1163/9789004506824_005 
Aleman's novel has led critics to differing conclusions, with some considering that the picaro behaves in a way which is completely immoral and cynical (Brancaforte 74-77), in contrast to others who argue that, in the face of two morally problematic solutions, the protagonist simply opts for the lesser evil (Cavillac 1993: 172-174). ${ }^{1}$

The great interest aroused by the ingenious close of the work has led to other issues and other chapters which are also highly relevant to the relationship between the novel and casuistry being overshadowed. An example is the work's beginning and the 'case' - or parody of a case - posed by the life of the protagonist's father, who infringes upon the most basic rules of morality and does not hesitate in apostatizing, but for whom possible excuses are constantly and ironically sought, stressing the particular mitigating circumstances:

La nave fue saqueada y él, con los más que en ella venían, cautivo y llevado en Argel, donde, medroso y desesperado, el temor de no saber cómo y con qué volver en libertad, desesperado de cobrar la deuda por bien de paz, como quien no dice nada, renegó.

ALEMÁN 36 (here and in all other quotes: italics added) ${ }^{2}$

In this fragment, and in the chapter as a whole, in fact, the constant back and forth between the offenses committed and the circumstances, as well as the oscillation between the case and its interpretation, with both being used as a way of reaching a correct judgment, is reminiscent of an essentially casuistical structure that, if we look closely, reappears in many chapters of Alemán's novel.

Of course, I do not intend to cover - and even less so to exhaust - in these pages, a problem as complex as the relationship between Guzmán and casuistry. I will confine myself to one aspect of the work which has structural analogies with casuistry and casuistical thinking. I refer to the way in which the unprecedented problem posed by a rival sequel, appearing between the publication of the two parts of the novel, is formulated and addressed by Mateo

1 In another study, Cavillac directly relates this scene, in which Guzmán uses dissimulation, with casuistical morality and the notion of Reason of State (2010: 122-23).

2 In this same opening chapter, in which the 'case' of Guzmán's father is more or less set out, and on which the reader has to pass judgment, there is, incidentally, an indirect and ironic allusion to casuistry, when the picaresque narrator says: "solo es Dios el juez de aquestas cosas; mire quien los absuelve lo que hace” (Alemán 38). The contribution of David Mañero Lozano to the present volume considers this and other casuistical scenes in Guzmán de Alfarache - ones that will be questioned in La pícara Justina. 
Alemán. As is well known, in the year 1602 a work entitled Segunda parte de la vida del pícaro Guzmán de Alfarache, by Mateo Luján de Sayavedra, ${ }^{3}$ was published in Valencia, thereby frustrating Aleman's plans, since he appears to have already made good progress with his own Second Part. Although, at a first glance, the relationship with casuistry is not as explicit here as in the two previously cited examples, a careful examination of the way in which Alemán presents the problem in the work's paratext and then converts it into novelistic material within the framework of the work of fiction reveals various connections with casuistry.

Given that someone had appropriated the work that he himself was continuing, Alemán was faced with an extreme situation, an authentic 'case' involving the law, morality, and poetics. In fact, for all that Alemán considers said appropriation to be illicit, he cannot rely on the law to judge it and impose a sentence on the perpetrator, as at the time there was no legal recourse against what we now call 'plagiarism'4 This led him to refocus the issue and explore other - moral and literary - aspects of it. At that time, there were no comparable precedents - such as the conflict between Avellaneda and Cervantes which might have served as a guide for the novelist and provided him with inspiration in determining how to act. For these reasons, the mere act of laying out the case properly for the reader constituted an unprecedented intellectual and artistic challenge. Was the offense committed legal, moral, or aesthetic in nature? According to which previous paradigms should it be judged? And, depending on how these questions were answered, what, ultimately, should the appropriate sentence be?

The difficulty of defining the case can already be seen in the work's paratext, in which Alemán approaches the problem by presenting it sometimes as a theft, and at other times as a challenge. He affirms in the prologue: "[...] por

3 Mateo Luján de Sayavedra is a pseudonym and the true name of the plagiarist is unknown, although within his work of fiction Mateo Alemán appears to accuse the Valencian lawyer and poet Juan Martí, as we shall see further on.

4 From a strictly legal point of view, as Hélène Maurel-Indart explains, plagiarism did not exist prior to the invention of intellectual property in the 18th century (Maurel-Indart 120-126 and 193), which did not prevent numerous early authors - several of them from the Roman period - from complaining that their work had been "stolen" by others. However, in the typology of plagiarism established by the Italian Jesuit Daniel Bartoli towards the middle of the 17th century and therefore a little later than Guzmán, there is still no case cited which is comparable to that of Mateo Alemán. The Jesuit, in fact, only cites as explicitly reprehensible the act of exclusively copying one or more other texts to the letter when composing a text, the act of concluding an almost finished text written by another and claiming authorship of the same, or the act of self-attributing a piece of writing that has been wholly written by another, signing it with one's own name (Bartoli 88-93). 
haber sido pródigo comunicando mis papeles y pensamientos, me los cogieron a el vuelo. De que, viéndome - si decirse puede - robado y defraudado, fue necesario volver de nuevo al trabajo" (Alemán 353). The case is viewed here as an act of robbery that merits the reader's censure; however, the perspective adopted in the novel's dedication is very different, with the author declaring:

Ya es conocida la razón que tengo en responder por mi causa en el desafío que me hizo sin ella el que sacó la segunda parte de mi Guzmán de Alfarache [...]. Espérame ya en el campo el combatiente; está todo el mundo a la mira. Son los jueces muchos y varios [...].

ALEMÁN 349-350

This time it is presented as a challenge, which has a lot of common ground with casuistry5: Alemán seems to insinuate that by taking over his creation, Luján de Sayavedra has injured his own reputation, his 'honor' as a writer. While in the prologue it was about determining how the thief should be punished - or how to settle accounts with him - what is now at stake is whether or not to accept the challenge and, where necessary, to define the modalities of the duel.

In this essay, I will study the 'Sayavedra case' on two very different levels. In the first part of my analysis, I will attempt to demonstrate that the role Alemán gives his work of fiction is that of investigating the case, scrupulously examining its different legal, moral, and literary facets. We shall see that plagiarism is first approached as an act of theft, and that the first solutions considered are legal and moral in nature, but that, little by little, the idea of a challenge is superimposed on this first understanding of the issue. The challenge implies a shift, which is sometimes playful, towards questions of poetics and aesthetics. In the second part, I will then center on another very different aspect of the question, making use of another kind of homology (structural analogy) between Alemán's search for a solution and casuistical thinking. I will ask, in a more literary sense, what the 'probable' opinions were, that is, the models or comparable literary 'cases' which could have inspired Mateo Alemán in responding to his emulator. Which of these prevailed, and to what extent were such paradigms adjusted when applied to the specific circumstances of the case?

In the course of my analysis, I would like to show that, despite exploring the different aspects of the matter by constantly moving between the legal, the moral and the literary, Alemán's work of fiction is ultimately far from choosing between them once and for all, leaving the perceptive reader with a wide

5 On the casuistry of the duel, see Chauchadis $175^{-182 .}$ 
margin for interpretation. However, this striking characteristic constitutes, in my opinion, another crucial link with casuistry which, as it developed, gave an increasingly prominent place to the individual conscience. ${ }^{6}$

As indicated previously, after the author lays out a synthesis of the general coordinates of the case in the paratext, the case becomes authentic novelistic material in the body of the work. The work of fiction is thus the framework in which the specific circumstances of the case, and the different possible options to resolve it (legal, moral, and literary), are examined. To this effect, Mateo Alemán envisions an ingenious solution, in two acts. Firstly, the theft of Guzmán's trunks: not long after the protagonist's story resumes in Rome, he is robbed of his most valuable possessions by a picaro called Sayavedra, one of the surnames of the sequel-writer. Through the theft of these valuable trunks the writer metaphorizes the plagiarism that is mentioned in the prologue. The second act begins when he meets the thief for a second time: a short time afterwards, the destitute protagonist runs into the traitor at the gates to Siena, where he has been detained by the law. This is where the case is examined in detail, opening with a confession of the crime and its circumstances, and later being concluded by the offender giving a detailed autobiographical account.

\section{In Search of an Impossible Legal Solution}

Sayavedra's arrest by the representatives of the law in Siena allows a first means of resolving the problem to be explored, with an initial focus on its being a simple theft, and therefore having a legal dimension. However, the limits of this approach are clear in that it does not allow the case to be perfectly formulated and even less to be adequately resolved, for two main reasons. In the first place, because there is a profound misalignment between the crime committed and the punishment of public infamy and banishment envisaged by the legal institution: in fact, as Guzmán himself stresses, what does being condemned to public shame and exile, that is, separation from the community

6 This essay owes much to the work of Boarini and Valadier, who are the point of departure of my research. I would also like to express my gratitude to Patrick Goujon, sJ, whose valuable advice guided my first steps in the field of casuistry. 
which had already marginalized him, matter to Sayavedra - a picaro without honor and without roots? And, secondly, in what way does the victim benefit from this? It goes without saying that the sentences handed down profoundly frustrate the protagonist's expectations, who hoped to recuperate what was stolen, while the intended sanctions do not in any way compensate for the damage suffered. The matter is further complicated when the protagonist discovers that the responsibility for the theft is not individual but collective: after a rigorous interrogation and careful consideration of the facts, Sayavedra turns out to be but a stooge, a low-level thief at the service of the powerful Alejandro Bentivoglio, the leader of a group of thieves based in Bologna, and the one who now appears truly responsible for the operation (being in possession of most of the stolen goods).

The exploration of the legal aspect of the case thus leads the protagonist to Bologna, where Guzmán, advised by a lawyer, presents a complaint against Bentivoglio. In this part of the novel, the word "caso" - in the legal sense of the term - is used on multiple occasions: Fuimos de parecer que yo por un tercero hiciese hablar a su padre, dándole cuenta del caso (Alemán, 483); determinéme a hablar a un estudiante jurista de aquella universidad, que me informaron tener buen ingenio, a el cuál haciéndole relación del caso [...] que me diese parecer en lo debería hacer (Alemán, 484).

However, contrary to expectations, the situation is suddenly turned upside down, with the protagonist ending up in jail, while Bentivoglio continues to rob others with impunity:

A el padre ledieron cuenta del caso y, como quien tanta mano allí tenía, se fue al juez [...] criminándole mi atrevimiento [...] Yo escupí al cielo: volviéronse las flechas contra mí, pagando justos por pecadores.

ALEMÁN 484-485

Since the culprit is the son of a powerful magistrate of the city, he remains beyond the reach of the law, while Guzmán - the victim of the robbery - is convicted for having slandered that 'respectable' family. As can be seen, given the corrupt legal system, the search for a legal solution does not allow the case to be solved adequately, compelling the protagonist and his creator to look for another means of compensation. 


\section{Exploring Alternative Solutions: Moving between Moral Condemnation of the Theft and Literary Emulation}

Thereafter, the novel explores other possible ways in which the case can be reconsidered and resolved more appropriately, displacing the problem to moral and literary spheres. In order to properly understand the way in which Alemán carries out this process, it is important to remember that since the second meeting between Guzmán and Sayavedra, at the gates of Siena, the protagonist's repentant alter ego has started to work for him. Due to this peculiar configuration, Guzmán has at his disposal a whole range of possibilities, from a pardon to revenge. It is not surprising, given Guzmán's personality, that a true pardon is ruled out; moreover, almost from the beginning, the protagonist sees his relationship with Sayavedra as a form of compromise. ${ }^{7}$ In contrast, it is striking that the protagonist does not explicitly contemplate plotting revenge - as he does, for example, with his Genovese relatives.

To explain this, it should be borne in mind that Sayavedra is a complex entity; that in the episodes that follow he is both Guzmán's alter ego, a projection of the rival writer and an allegory of the spurious work, whose publication is perceived by the primary author not only as a theft, but also as an offense. The proper solution cannot, therefore, be punishment or revenge in the traditional sense. Punishing Sayavedra would only make sense if it allowed him to teach the rival writer a lesson, and, in the same way, killing or injuring the challenger takes on a different significance depending on whether we consider the latter to be a man of flesh and blood, a fictional double of the sequel-writer or a 'man-book'. ${ }^{8}$ For all of these reasons, in this section of the novel the problem posed by the dialectic of punishment and vengeance develops in a highly polysemic context, which is impossible to resolve without taking into account the double - or triple - levels on which the 'case' can be read.

After the Bologna fiasco the two pícaros continue to travel through Italy together and Sayavedra, who has now become Guzmán's lackey and disciple symbolically marking his inferiority -, tells his new master about his life in a detailed manner, as if he were a penitent during a confession, dwelling on the most remarkable thefts that he has committed over the course of his miserable

7 The protagonist says, just after seeing the thief again, that the thief had offered to serve him in order to reform himself: "Aunque verdaderamente yo sabía ser aquél muy gran ladrón y bellaco, túvelo por de menor inconveniente que de necio [...] Parecióme que, si de alguno quisiera servirme, habiendo pocos mozos buenos, que aqueste sería menos malo" (Alemán 467). Conscious of living in an imperfect and changing world, Guzmán seems to follow the choice of a lesser evil as a standard of conduct.

8 By "man-book," I refer to the way in which Sayavedra at times functions as a sort of allegory for the spurious continuation. 
existence. Guzmán, who thereafter occupies structurally the place of the confessor, rises to the pulpit and imparts a series of lessons on the true nature of robbery:

No andes a raterías, hurtando cartillas, ladrón de coplas, que no se saca de tales hurtos otro provecho que infamia (Alemán 507); Que, con parecerme a mí, como era verdad, que cuanto me había contado Sayavedra era desventurada sardina y yo en su respeto ballena (Alemán 522); Quien se preciare de ser ladrón, procure serlo con honra, no bajamanero, hurtando de la tienda una cebolla y trompos a los muchachos (Alemán 523).

There is evidently something ironic and perhaps parodic in the attitude of Guzmán the confessor, since he does not try to instruct Sayavedra so that he does not rob again, before absolving him, but rather encourages him to rob more successfully going forward. The conclusion that can be drawn from this sequence is, therefore, not moral in nature but instead poetic, as if Sayavedra's deficiency - both the author and the character - as regards the theft had in some way insulted his model. Sure enough, by emphasizing the errors committed by the protagonist's alter ego, it is above all the literary deficiencies of the sequel-writer that are underlined, with the latter being undermined as a literary rival. This is, therefore, the punishment given: a scathing review, as it were.

Another option, itself ambiguous, which is explored in the episodes that follow, consists of dramatizing a rematch that can be read in two ways: that of Guzmán facing his double and that of Alemán facing his competitor. The most representative episode is the famous trick played on the Milanese merchant in which Alemán's picaro, using a brilliant strategy, steals an enormous sum of money from a rich moneylender, with Sayavedra actively complicit. The rematch - in an almost sporting and playful use of the term - seems to be a substitute for revenge here and works, again, on two levels: firstly, Guzmán, impoverished by Sayavedra's theft, now becomes rich again thanks to him; however, Alemán also puts right what he considers to be the 'poetic defects' of his sequel-writer who, in his judgment, had shown himself incapable of converting Guzmán into a "ladrón famosísimo," such as he had promised in $1599 .{ }^{9}$ Thus, the robbery of the Milanese 'merchant' also represents a symbolic

9 Mateo Alemán had indeed specified in the "Declaración para el entendimiento de este libro," published in 1599 with the First part of the novel, that in the Second Part penned by him his pícaro would become a "ladrón famosísimo" (Alemán 16), which is far being accomplished in the Second Part penned by Luján. 
overcoming of the rival. In fact, at the end of the episode, Sayavedra's theftchallenge - character and sequel-writer - undergoes a reversal:

Después que vi tanto dinero en estas pobres y pecadoras manos, me acordé muchas veces del hurto que Sayavedra me hizo, que, aunque no fue tan poco que para mí no me hubiera hecho grande falta, si aquello no me sucediera tampoco lo conociera ni con este hurto arribara; consolábame diciendo: "Si me quebré la pierna, quizá por mejor; del mal el menos".

ALEMÁN 541

Just as the stolen trunks are doubly metaphorized as the damage caused by Luján's work, the chests overflowing with money are now the projection of the great literary benefits that Alemán has drawn, paradoxically, from Luján's act of plagiarism. This is the conclusion to be drawn from Guzmán's words, which are clearly metapoetic in scope. In essence, the robbery presents itself in this episode as something morally legitimate, since it consists of robbing from a thief (a moneylender ${ }^{10}$ ), and poetically just, as it allows the sequel-writer's offense to be rectified.

After the punishment and the rematch, which tended to move the problem into the realm of poetics (with a playful dimension), Alemán's novel tests a third and final option which connects more conventionally to the dialectic of revenge and punishment, but with Alemán continuing to tell a story that can be read two ways. When it looks as if Guzmán can be at peace with his double, master and servant set sail for Spain from the port of Genoa, at which point a highly dramatized storm breaks out. Believing themselves to be close to death, all of the travelers confess their sins out loud. In this singular context, overcome by a violent fever, Sayavedra suddenly declares that he is Guzmán de Alfarache, before throwing himself into the water to be buried forever:

Cuando confesaban los otros los pecados a voces, también las daba él diciendo: “¡Yo soy la sombra de Guzmán de Alfarache! ¡Su sombra soy que voy por el mundo!" [...] iba repitiendo mi vida, lo que della yo le había contado, componiendo de allí mil romerías [...] todo lo decía de símismo, como si realmente lo hubiese pasado [...].

ALEMÁN 583

10 According to Michel Cavillac, Aleman's position in this chapter should not be understood as a diatribe against capitalism, but rather against its excesses, in accordance with the casuists Martín de Azpilcueta and Francisco García's theory of lucrum moderatum (Cavillac 1988: 134-135). 
At a first glance, what is dramatized here is a sort of 'poetic justice', whose role consists of symbolically punishing - once and for all - the person responsible for the theft perpetrated and the offense committed. However, all things considered, it is very difficult to deliver an unequivocal judgment on this final scene, which itself constitutes a 'case' in miniature. Are we witnessing an act of insanity, as is suggested by the repeated use of the word "locura," or the confession of a grave sin - Guzmán's identity being usurped - as can be inferred from the apocalyptic context in which the scene plays out? On the other hand, if one subscribes to the hypothesis of a providential punishment, the least that can be said is that Alemán's God does not seem to be very fair. As we have seen previously, Sayavedra was not truly responsible for the crime, and has done all that is possible to atone for his sin by serving the protagonist loyally. Are we, therefore, witnessing a just punishment, or a disguised vengeance from Alemán's demiurge? In other words, does the fiction dramatize poetic justice or the sacrifice of a scapegoat?

The difficulty in passing a firm judgment grows when the other travelers, moved by compassion, come to Guzmán to pass on their condolences for the loss of his faithful companion, to which the protagonist cannot offer any commentary other than the following: "Sinifiqué sentirlo, mas la verdad sabe Dios" (Alemán 583). ${ }^{11}$ In addition to the question of how we interpret the final suicide of the double, there is now another issue: that of the judgment that Guzman's attitude itself deserves. Faced with this situation, the protagonist's conscience is clear, in principle, since, as the text makes clear, his double dies 'by accident' and, therefore, the protagonist cannot be considered responsible for his death. Furthermore, strictly speaking, Alemán's picaro has not avenged himself. Rather, he has limited himself to defending his honor as a thief ${ }^{12}$ in the preceding chapters, humiliating his double and giving him a lesson on the

11 The text seems to link here with the problem of pretense and dissimulation, which was debated at length by the casuists. On this complex problem, please see the reflections of the French Jesuit historian Gabriel Daniel $(378-383)$. As noted above, Cavillac also deals with dissimulation in Guzmán de Alfarache, mentioning the casuist Ribadeneyra (Cavillac 2010).

12 I have not been able to develop this aspect of the question, which no doubt merits further examination to confirm the link to casuistry. There are various discussions on vengeance, especially in response to an offence being committed, in casuistical literature. The French moralist Pascal (1623-1662) echoes these in his Provincial Letters, not without a certain amount of bad faith. In the seventh letter, when evoking the conflict between Christian morality and social morality, he refers to the case of vengeance and is outraged that, for certain casuists, avenging oneself is sinful, whereas it is just, in contrast, to want to avoid public shame by defending your honor (Pascal 116-117). Guzmán's attitude with regard to Sayavedra seems to have certain affinities with this position. For discussions 
act of stealing - before finally expressing, in the midst of a general confession, a concealed delight in his death.

Faced with this new and extreme situation which, unlike other chapters, is not accompanied by even the smallest gloss by the protagonist-narrator, the reader is solely responsible for passing judgment. The reader is not only called to pass judgment on Sayavedra's attitude to Guzmán, but also on Guzmán's attitude to Sayavedra: in the course of the second book, the two have almost come to exchange their respective roles of persecutor and victim. However, the judgment handed down changes depending on whether the Sayavedra who dies in this scene is considered to be Guzmán's alter ego - a man of flesh and blood, a fictional double of the sequel-writer, or an allegorical character who embodies the rival work. What was initially presented as a challenge for Mateo Alemán finally becomes a challenge for the "discreto lector" of the work.

An Exercise in Literary Casuistry or the Frustrated Search for Similar 'Cases'

I will now focus on another way of approaching the relationship between Guzmán and casuistry. I would like to underline the homology (or structural analogy) between, on the one hand, the novelist's search for 'authorized' literary models to respond to the act of plagiarism, and, on the other hand, the casuist's examination of different probable opinions to resolve a moral case. Both situations involve searching for a solution by connecting the current case with previous cases - literary or moral - to help reach a judgment and determine a sentence or a mode of conduct. In this respect, my hypothesis is that Alemán hesitated fundamentally between two main paradigms (or 'probable' opinions): on the one hand, a model inherited from Antiquity, which encouraged him to approach the case as plagiarism, as he does in the prologue; and, on the other, a second paradigm offered by sequels to chivalric romances, which led him to consider the problem as a challenge, as he does in the dedication.

Among the authors from the ancient world who are best known for denouncing plagiarism - understood not as a legal problem but a moral one - is Horace, whose work was well-known in Spain thanks to the work of the humanists. In fact, the fable of the Crow in Borrowed Feathers, Horace's famous diatribe against plagiarists, is mentioned in Covarrubias' Diccionario in the entry for "corneja," where the lexicographer states:

on vengeance in the work of Spanish casuists, see for example Azpilcueta f. $272 \mathrm{v}-273$, Ribadeneyra 470 and Escobar y Mendoza $477^{31}$. 
La corneja desplumada y al rededor della muchas plumas de diversas colores, sinifica el que se ha querido honrar con escritos agenos, publicándolos por suyos, y queda corrido quando es tomado en el hurto. Desta fábula hizo mención Horacio, etc.

COVARRUBIAS $35^{8}$

The essential idea demonstrated in this fable is that the plagiarist should be unmasked, and that, if the theft is made public, humiliation and shame will ensue. Thus, the best weapon to fight plagiarism is public censure: the unmasking of the fraud serves as punishment. The fable of the crow is not explicitly mentioned in the Second Part of Guzmán, but it constitutes an implicit (or structural) model that is present throughout book two of the Second Part. At times Alemán clearly makes it his own, for example when, during his autobiographical account, Sayavedra reveals the true name of the sequel-writer (Juan Martí), introduced by Guzmán's alter ego as his older brother:

Fuemos dos hermanos y ambos desgraciados [...] y para en cualquier trabajo no ser conocidos ni quedar con infamia, fuemos de acuerdo en mudar de nombres. Mi hermano [mayor], como buen latino y gentil estudiante, anduvo por los aires derivando el suyo. Llamábase Juan Martí. Hizo del Juan, Luján, y del Martí, Mateo; y volviéndolo por la pasiva, llamose Mateo Luján [...] y yo, sabiendo ser caballeros principales los Sayavedras de Sevilla, dije ser de allá y púseme su apellido.

ALEMÁN 508-509

In this same vein - that of unmasking as a punishment - another ancient fable, attributed to Avianus - the fable of The Ass in the Lion's Skin - is mentioned twice, once in the paratext and once in the body of Alemán's text:

[un asno se] vistió el pellejo de un león para espantar a los más animales y, buscándolo su amo, cuando lo vio de aquella manera, que no pudo cubrirse la orejas, conocióle, diole muchos palos: y, quitándole la piel fingida, se quedó tan asno como antes. ${ }^{13}$

ALEMÁN 447

13 The other mention of the fable, found in the work's "Elogio" by Luis de Valdés, is more allusive but also clearly associated with the work by Luján de Sayavedra: "Testifica esta verdad el valenciano que, negando su nombre, se fingió Mateo Luján por asimilarse a Alemán [...] en el mismo año que salió [el libro] lo compré yo en Flandes impreso en Castilla, creyendo ser legítimo, hasta que, a poco leído, mostró las orejas fuera del pellejo y fue conocido" (Alemán 359-360). 
Incidentally, it is significant that this fable of Aesopian roots is mentioned just before Sayavedra first appears, therefore providing a valuable indication of how the story will unfold. Its specific location, just before the fictionalization of the 'Sayavedra case' in the body of the novel, gives it an 'authoritative' status, suggesting that it will help to resolve it.

However, what continues to be problematic is that Sayavedra's sequel cannot easily be considered plagiarism of the original literary enterprise, at least not in the sense that Horace and Avianus understand plagiarism. Indeed, both the extent and the nature of the 'theft' are very different in each case. In the earlier examples, some lines were copied exactly: with Horace, what was stolen were not only words but also a way of combining vowels and linking them together. Sayavedra, on the other hand, was inspired by the general idea of Alemán's novel and developed his own sequel in particular directions which have been outlined by Alemán. Do a short and direct borrowing, and an indirect borrowing coupled with the selection and extension of narrative pathways, amount to the same thing? It goes without saying that the opinions of Horace and Avianus are far from fitting the particularity of this case perfectly, hence the need to consider other options and consult other authorities.

Doubtless conscious of these imbalances, Alemán considers other approaches and turns to other 'probable' opinions to outline and then attempt to resolve the case. The main one is the paradigm inherited from chivalric romances and derived, more specifically, from the literary practice of sequel writing. For obvious reasons, this paradigm did not enjoy the same prestige as Horace's novel - it can therefore be considered less 'probable'. However, it does fit certain circumstances and specific variables of the case more closely. I refer, on the one hand, to the type of literary appropriation - a 'continuing' of the story - carried out by Luján; on the other, to the fact that the sequel-writing paradigm grants a more prominent place to the notion of emulation, which is consistent with the idea of a challenge expressed in Alemán's dedication.

At times, the literary practice of sequel writing led to bitter polemics between rival sequel-writers. The most famous cases are between sequelwriter Feliciano de Silva and various competitors, such as Páez de Ribera and Juan Díaz, whom Silva attacks in the paratext of Amadís de Grecia (1530), and later Pedro de Luján, whom Silva attempts to discredit in the paratext of Cuarta parte de Florisel de Niquea (1551). ${ }^{14}$ In essence, Silva uses two main argu-

\footnotetext{
14 Silva attacks Páez de Ribera (author of Florisando or Amadís VI, published in 1510) and Juan Díaz (author of Lisuarte de Grecia or Amadís viI, published in 1526) in the paratext of his Amadis de Grecia (or Amadís VIII), published in 1530. The polemic between Pedro
} 
ments to discredit competitors' sequels which interfere with his own: on the one hand, their falseness - that is to say, that they are a sort of 'lie' with respect to what, in his opinion, was to be expected based on the initial work - and, on the other hand, their terrible quality:

El que hizo el octavo [libro] de Amadís y le puso nombre de Lisuarte no vio el sétimo, y si lo vio no lo entendió ni supo continuar. [...] Y fuera mejor que aquel octavo feneciera en las manos de su autor y fuera abortivo que no que saliera a luz a ser juzgado y a dañar lo en esta gran genealogía escrito, pues dañó a sí poniendo confusión en la decendencia y continuación de las historias.

SILVA, Amadís de Grecia, 1530, cited in Ramos 133

Esta es la verdadera historia destos príncipes, y otra, que parescerá tractar de la mesma historia, bien parece que fue más escrita por afición que por información de las verdaderas historias destos príncipes [...]. Ansímesmo, el niño don Silves de la Selva, quedó tan chico que en todas estas pruebas passadas no fue posible hallarse en ellas ni tenía edad para ello [...] El estilo y frasis de Galersis que tan gran historia escrivió, [es] muy diferente de la historia que se llama Don Silves de la Selva [...].

SILVA, Cuarta parte de don Florisel de Niquea, 1551, cited in Ramos 133 n. 43

This second paradigm - or probable opinion - adopted by Silva, conceived sequel-writers of the same series to be engaged in a competition or literary joust, rather than seeing their relationship as that of persecutors and victims, fraudsters and victims of fraud. He thus tended to elevate the problem of literary appropriation to the level of an aesthetic challenge which involved notions of the work's coherence and style, in a sense ennobling both writers with respect to Horace's model. We do not know for certain whether Alemán read Silva's works directly. When Alemán attacks chivalric romances, in the third book of the Second Part of Guzmán (chapter 3) in particular, he never cites them explicitly. However, there is a striking similarity between the arguments developed by Alemán against Sayavedra and those used by Silva to discredit a number of his literary rivals. Both in the body of the text, and in the paratext, Alemán appropriates the two central arguments used by Silva, namely: the

de Luján, author in $\mathbf{1 5 4 6}$ of Silves de la Selva, is later and appears in the paratext of the Cuarta parte de Florisel de Niquea (1551). For more details, see Ramos 131-134. 
lying nature of the rival work and the inferiority of the rival novel compared to the novel that it was emulating.

It is Guzmán himself who expresses most forcefully the argument of falseness and of lying, when he says, a short time after picking up the thread of his tale: "La verdadera [vida] mía iré prosiguiendo [...]. Y no faltará otro Gil para la tercera parte, que me arguya, como en la segunda, de lo que nunca hice, dije ni pensé" (Alemán 378). This accusation of unfaithfulness is also present in the prologue to the work, but it is directly linked, in this case, to the second criticism, the idea of inferiority with respect to the model. As Alemán affirms, since the sequel-writer has limited himself to developing the novel's picaresque dimension without taking into account its moral dimension, it has utterly failed, offering its readers a superficial work which does nothing more than impoverish the earlier material: "Advierto en esto que no faciliten las manos a tomar la pluma sin que se cansen los ojos y hagan capaz a el entendimiento; no escriban sin que lean, siquieren ir llegados a el asumpto sin desencuadernar el propósito" (Alemán 354). ${ }^{15}$ In summary, Alemán, like Silva, adds an aesthetic and poetic dimension to Horace's condemnation, which is primarily moral in nature. A ludic dimension is also added, from the moment an alter ego of the protagonist, named Sayavedra, is inserted into the body of the novel.

Regarding Horace's model, this second 'probable' opinion - the chivalric paradigm - allowed the literary emulation aspect of our case to be taken into account, though the fit is not perfect. Silva's ideas about the novel clashed decidedly with Mateo Alemán's literary sensibility on various levels. It is important to take into account that another - more implicit - reason why Silva directs his arrows towards Páez de Ribera and Juan Díaz is their intention of 'moralizing' chivalric romances. ${ }^{16}$ Both tend, for example, to expunge all the magical elements from fiction, an option that Silva roundly rejects, since, in his opinion, the pleasure of reading should prevail over the moral improvement of the readers. However, Alemán, who aims for his work to "enseña[r] por su contrario/la forma de bien vivir" (Alemán 25$)^{17}$ and, in the Second Part, reminds us insistently of the moral dimension of the fable - precisely the one which his sequel-writer discarded - could not easily identify fully with an author who

15 In complementary fashion, the accusation of falseness - present in Silva's criticisms - is also taken up again in Valdés' “Elogio" (Alemán 359-36o).

16 On this subject, see Chevalier 441-449, Roubaud 189-205 and Sales Dasí 117-152.

17 The original phrase, situated in the paratext, is not from Alemán himself but from one of his friends, Hernando de Soto, however it summarizes very neatly the general purpose of the book. 
places pleasing the public above their moral instruction, and whose conception of the novel, deep down, is closer to Luján de Sayavedra's than his own.

As can be seen, none of the 'probable' opinions available completely match the case that Alemán must pass judgment on, for different reasons. Horace enjoyed the prestige of Antiquity but, since he limits himself to denouncing plagiarism to incite the public's moral reprobation, does not allow Alemán to meet the challenge laid down by his rival. In contrast, the option offered by Silva allowed this dimension to be taken into account, but inevitably linked Alemán's novel to a controversial genre - the chivalric romance - from which Alemán wanted to distance himself. He wanted to inscribe himself into Horace's tradition of delighting instructively. Such a goal was in opposition to the "delighting delightfully" of Silva's novels, full of fantasy and magical elements, and devoid of moral-instructional purpose.

Faced with this series of misalignments between the case to be resolved and the available models, Alemán ultimately preferred not to choose, but rather to opt for a hybrid solution which integrated elements from both paradigms: unmasking the fraud and moral reprehension, on the one hand; and criticisms of a poetic nature and of literary emulation, on the other. What class of casuist is the author of Guzmán, therefore? There is no doubt that the label of 'tutiorist' must be discarded straight away, because Alemán takes into account various options and adapts to the particular and shifting context in which events take place - granting, furthermore, a prominent place to individual conscience. Should we perhaps infer that Alemán is a 'probabilist', in the sense that he considers different solutions without putting them into a clear hierarchy and without necessarily abiding by what is most probable (fabricating what is, in a sense, an 'à la carte' solution)? Or perhaps he should be considered a 'laxist' for having relied on a doubtful opinion - that of the author of the second or third category (Silva), abusively granting him the status of 'authority'?

Certainly, the homology between the 'Sayavedra case' and a case of conscience reveals its limits here. Unlike the casuist or the penitent, the novelist enjoys the enormous privilege of being able to juggle different options and existing opinions without having to make a choice once and for all. What is interesting for the novelist is not so much the result of this examination of conscience but the process and the search for complementary solutions. It is not surprising, therefore, that it is often the reader who is faced with the difficult task of passing judgment. Freed from the constraints of external authority in these instances, we become aware of our subjectivity, and also of the burden of making sense of the situation. 
In short, Alemán lays out in the paratext various possible options to respond to the question 'what must be done?' with the 'Sayavedra case' which is presented sometimes as a theft and at other times as a challenge, both of which are unique. However, it is within the fictional narrative that the particular circumstances of the case are truly examined: the fictional narrative reveals that unmasking the 'Sayavedra case' is not as straightforward as might have been expected, nor is judging Guzmán's own attitude towards his thief. At every moment, an additional piece of information appears, a new detail is brought to light about the circumstances, or a new retrospective commentary appears which destabilizes or confuses the judgment that we were constructing with considerable difficulty.

That said, this peculiar configuration, which converts what is shifting and unstable into literary principles, can have two opposing effects on the reader. It can discourage them and even lead them to a pessimistic conclusion: the work demonstrates constantly that, in order to judge a situation, one almost never has all of the necessary information at one's disposal, thus, the reader can end up doubting the very possibility of reaching a successful verdict. However, the virtuosity of Alemán's writing, characterized by a constant shifting between the case and its interpretation, can also lead to a more optimistic reading of the novel: a reading which is more sensitive to the ludic role that Alemán's literary project implies, and more open to rejoicing at the aesthetic joy that ambiguity supplies. As has been seen, there are numerous occasions in which Guzmán does not address Sayavedra the character but Sayavedra the sequelwriter, thus creating an intensified ambiguity which turns interpretation into a ludic challenge for the reader's judgment.

The conclusion that follows the frustrated search for related literary cases, and which leads Alemán to hesitate between two imperfect paradigms, is a little different, though not so distant. Everything seems to indicate that the relative absence of pre-existing models which fitted the 'case' was a powerful incentive for creativity and for moving beyond the frameworks in use. Indeed, with the creation of the protean character of Sayavedra, without known precedent in Spanish literature, Alemán profoundly questioned exemplarity, the very applicability of models. Hence, having to write a novel about a 'case' partly imposed from the outside - turned out to be at once a form of coercion with regards to the novelist's freedom, and a powerful motor for his creative activity. This fertile dialectic between the case, on the one hand, and its interpretation and literary transfiguration, on the other, can only encourage us to 
question in greater depth the complex relationship between casuistry and the birth of the modern novel.

\section{Works Cited}

Alemán, Mateo. Guzmán de Alfarache. Ed. Luis Gómez Canseco. Madrid: Real Academia Española, 2012.

Azpilcueta, Martín de. Manual de confessores, y penitentes. Ambéres: Martín Nucio, 1555.

Bartoli, Daniel. El hombre de letras, escrito en italiano por el Padre Daniel Bartoli, de la Compañía de Jesús, y traducido por diversos autores en latín, francés, inglés y portugués, y ahora nuevamente en castellano por Gaspar Sanz, presbítero [1678]. Madrid: Benito Cano, 1786.

Boarini, Serge. Qu'est-ce qu'un cas moral? Paris: Vrin, 2013.

Brancaforte, Benito. Guzmán de Alfarache: ¿conversión o proceso de degradación? Madison: The Hispanic Seminary of Medieval Studies, 1980.

Cavillac, Michel. "Genèse et signification de la bourle de Milan dans le Guzmán de Alfarache (II P., II, V-VI) de Mateo Alemán”. Bulletin hispanique 9o.1-2 (1988): 119-145.

Cavillac, Michel. “Les trois conversions de Guzmán de Alfarache (Regard sur la critique récente)". Bulletin hispanique 95.1 (1993): 149-201.

Cavillac, Michel. Guzmán de Alfarache y la novela moderna. Madrid: Casa de Velázquez, 2010.

Chauchadis, Claude. La loi du duel: le code du point d'honneur dans l'Espagne des XVI XVIII ${ }^{e}$ siècles. Toulouse: Presses Universitaires du Mirail, 1997.

Chevalier, Maxime. "Le roman de chevalerie morigéné: le Florisando". Bulletin hispanique 60.4 (1958): 441-449.

Covarrubias, Sebastián de. Tesoro de la Lengua Castellana o Española. Ed. Martín de Riquer. Barcelona: Editorial Alta Fulla, 2003.

Daniel, Gabriel. "Des équivoques et des restrictions mentales". Entretiens de Cléandreet d'Eudoxe sur les Lettres au Provincial. Cologne: Pierre Marteau, 1694.

Escobar y Mendoza, Antonio. Examen y practica de confessores y penitentes: en todas las materias de la theologia moral. Paris: a costa de Antonio Bertier, mercader de libros, 1665 .

Luján de Sayavedra. Segunda parte de la vida del pícaro Guzmán de Alfarache. Ed. David Mañero Lozano. Madrid: Cátedra, 2007.

Maurel-Indart. Du plagiat. Paris: Presses Universitaires de France, 2001.

Pascal, Blaise. Les Provinciales [1656-1657]. Ed. Michel Le Guern. Paris: Gallimard, 1987. 
Ramos Nogales, Rafael. "Las continuaciones y la configuración genérica de los libros de caballerías". La escritura inacabada. Coord. David Alvarez Roblin and Olivier Biaggini. Madrid: Casa de Velázquez, 2017:121-143.

Ribadeneyra, Pedro de. Tratado de la religión y virtudes que debe tener el principe christiano para gobernary conservar sus Estados. Madrid: Pantaleón Aznar, 1788.

Roubaud-Bénichou, Sylvia. Le roman de Chevalerie en Espagne. Entre Arthur et Don Quichotte. Paris: Champion, 2000.

Sales Dasí, Emilio. "Las continuaciones heterodoxas (el Florisando [1510] de Páez de Ribera y el Lisuarte de Grecia [1526] de Juan Díaz) y ortodoxas (el Lisuarte de Grecia [1514] y el Amadís de Grecia [1530]) del Amadís de Gaula". Edad de Oro 21 (2002): $117-15^{2}$.

Silva, Feliciano de. Amadís de Grecia [1530]. Ed. Emilio Sales Dasí. Alcalá de Henares: Centro de Estudios Cervantinos, 2002.

Silva, Feliciano de. Cuarta parte de don Florisel de Niquea. Salamanca: Andrea de Portonaris, 1551.

Valadier, Paul. Rigorisme contre liberté morale. Les Provinciales: actualité d'une polémique antijésuite. Paris: Lessius, 2013. 


\title{
Theological Casuistry and Casuistical Preposterousness: The Fallacious Cases of La pícara Justina
}

\author{
David Mañero Lozano
}

\begin{abstract}
The preliminary pages of La pícara Justina offer a parallel between a purported exemplary reading of Justina's story and court hearings for people accused of crimes, as well as theological views. However, the preposterous circumstances and the arguments used by the female rogue when attempting to exonerate herself, assume such a degree of narrative disproportion and distortion that the discourse moves into parody. Based on these observations, we analyze the function of casuistry within the framework of fictional literature.
\end{abstract}

\section{Keywords}

Casuistry - La pícara Justina - Picaresque novel - Female rogues - Guzmán de Alfarache - Exemplary literature

According to the preliminary pages of La picara Justina, the novel aims to allow lessons to be derived through examination of the thefts and deceptions perpetrated by its protagonist. To this end, the preface draws a parallel between a purported exemplary reading of Justina's story and court hearings for people accused of crimes, as well as theological views on impious actions. A priori, this declaration of intent - fulfilled through the inclusion of moral summaries at the end of each of the book's sections - is associated with the theological science of casuistry. However, the novel's reader comes up against a number of interpretive challenges. Despite the exemplary approach we are encouraged to take when reading about Justina's life, the preposterous circumstances described and the arguments used by the picara, or female rogue, when attempting to exonerate herself, assume such a degree of narrative disproportion and distortion that the discourse moves into the realm of parody. Moreover, as the novel unfolds there is a gradual confusion of the functions attributable to the voices of the implied author, the narrator, and the marginal notes, which lay out a 
complex dialectic that is difficult to equate with moral didacticism. Based on these textual points of reference and the intertextual relationships between La picara Justina and earlier picaresque novels, this paper aims to analyze the function attributed to casuistry within the framework of fictional literature. It explores, in short, an issue of broad theoretical and historiographical scope with a view toward furthering an understanding of the different conceptions of the novel that developed in Spanish Golden Age literature.

\section{1 \\ Exemplarity and Casuistry: An Interpretive Starting Point}

Few texts in Spanish literature pose as many interpretive challenges as $L a$ picara Justina, a novel from which, ironically, the reader is urged from the outset to draw useful lessons. In fact, even before the book's dedication and preface, the royal license (cum privilegio) at the beginning of the front matter highlights the purported exemplary ambitions of the author. The very first lines, attributed to the royal secretary, claim that said author submitted the book after a great deal of work and study, and describe its edifying function and the presence of "cosas muy curiosas" ("very intriguing content") relating to morality and "buenas costumbres" ("good customs", López de Úbeda 166).

The second of the preliminary texts, the approval, proceeds in the same vein, differentiating between the subject matter, which is on a superficial level, and the work's exemplary intent, which is "encerrada" ("enclosed") on an interpretive level that requires greater effort to comprehend. With respect to the immediately accessible level, allusions are made to the presence of comical stories and "tratos manuales" ("manual dealings") (169), which dictionaries from the era define as illicit communications or business between a man and woman. This definition for the word trato is given in the Diccionario de Autoridades, and its modification by the adjective manual (manual) encourages interpretation of the phrase as a reference to prostitution. As regards the deeper or "enclosed" meaning, the approval mentions the presence of teachings or warnings that are useful for the purpose of avoiding the "engaños que hoy día se usan" ("deceptions practiced these days").

Up to this point, the book's approach is in line with a long tradition dating from medieval times, ${ }^{1}$ although we must suppose it to have been somewhat refined by the influence of Mateo Alemán's Guzmán de Alfarache. It is

1 On the medieval roots of the notion of ejemplaridad ("exemplarity") in Spanish short stories from Disciplina Clericalis to Cervantes and his contemporaries, see González Ramírez, who repeatedly highlights the frequent contradictions between the purportedly exemplary 
common knowledge that this earlier work had brought a renewed, appealingly expressive format to didactic literature by combining consejas, or stories of roguish adventures, with consejos, or moral teachings. It is a well-defined structure with no place for misgivings, as Alemán notes when he advises "no te rías de la conseja y se te pase el consejo" ("don't laugh at the conseja and miss the consejo", 30). His comment makes it clear that the story takes second priority behind the lesson. In Guzmán de Alfarache we also see, as this paper will go on to explore, a new ideological conception wherein archetypical examples of moral conduct are displaced by an interest in evaluating an individual's conduct and conscience in a specific situation or set of circumstances. ${ }^{2}$ These sorts of approaches, undoubtedly prefigured in Lazarillo de Tormes, have been linked to the emergence, or awareness, of subjectivity in the modern novel. According to Maryks, this reflection on an individual's specific circumstances involves "an important shift that characterized the transition from medieval ethics into a modern mentality characterized by a higher degree of subjectivity, responsibility and interiority" (117-18).

This exemplary starting point, which is no doubt within the bounds of the reader's expectations, is immediately endorsed and later explicitly stated by the implied author of La picara Justina, whom it would be more fitting to describe as a literary character rather than the agent or person responsible for the work's ultimate meaning. ${ }^{3}$ Accordingly, in the book's dedication to Rodrigo Calderón, he is compared to a "preciosa abeja" ("precious bee") that knows how to extract "gusto y aprovechamiento" ("enjoyment and utility") from an entertaining read (López de Úbeda 171). However, it is in the preface that the implied author figure deploys all of his rhetorical tools to address the book's aims in detail, a fact that is directly stated in the preface's heading, which reads "En el cual declara el autor el intento de todos los tomos y libros de La pícara Justina" ("Wherein the author states the intention of all of the volumes and books of La picara Justina"). Significantly, the preface begins by endorsing the views of moral theologians who condemn profane books, which are branded as useless and lascivious. The immediate inference is that the author's work falls into a very different category. Indeed, he acknowledges that the subject matter of his novel is the "veneno de cosas profanas" ("poison of profane things"), but to counterbalance this he points to lessons on virtues and disappointments

function declared in paratexts and the plots of the stories themselves, which often undermine the preliminary comments.

2 On the emergence and development of subjectivity in the picaresque novel, see Mañero Lozano (2021).

3 As Dunn points out: “[...] the text of the female narrator is presented by an unidentified and implicitly male commentator" (233). 
"emboscados donde no se piensa" ("which lie in ambush where least expected") (179). This is yet another allusion to the reader who must make an effort to draw hidden teachings out of the text.

The preface also draws on another standard feature of sermon rhetoric: learning life lessons through someone else's experiences. The stated objective is to provide a comprehensive casuistry regarding moral dangers to be avoided. Initially, the book is described as useful for maidens and married women. It is then said to be useful for students, soldiers, apprentices, innkeepers, ministers of justice and, in short, all people of any status, acting in any capacity (184). There is thus a pursuit of totalization reminiscent of the aims of the moral theologians who evaluated cases of conscience, some as exhaustive as Antonino Diana, in Summa Resolutionum Moralium, whose desire to describe a vast number of cases (no less than twenty thousand) led him to include some utterly preposterous situations (cf. Vereecke).

Despite the conventional nature of the arguments set out up to this point, there are also two elements that make the implied author's hermeneutic approach particularly interesting. First, he describes himself as a "testigo" ("witness") to the protagonist's life, and claims that most of her story is true (182-183). After this surprising affirmation, which aims to legitimize an exemplary reading of Justina's thefts and deceptions, the story is compared to court hearings of accused criminals and to moral theologians' views on impious actions. In that sense, the relation between Justina and the implied author could be paralleled to that of a penitent to a confessor.

This interesting parallel, substantiated by Justina's autobiographical account of her story and moral recapitulations inserted at the end of each of the book's sections, would have been associated at the time with the ideological conception and rhetorical practices of casuistry, wherein moral postulates were based on analysis of the specific circumstances of cases of conscience. Remember, there is a fundamental difference between "case" and "example," which Del Río Parra aptly characterized when she noted that

Si bien ambos géneros se encuadran en la didáctica, la casuística atiende a despejar las dudas que presentan diversos casos prácticos (reales o posibles [...]). Mientras que el ejemplo considera una situación para concebir un principio abstracto, el caso se centra en lo particular dudoso, donde reside una gran dificultad moral para resolver esta última con éxito

Although both are encompassed within didactics, casuistry seeks to dispel doubts presented by different (real or possible case studies [...]). While the example considers a situation in order to formulate an abstract 
principle, the case focuses on the specific area of doubt, wherein lies a great moral challenge that must be resolved.

DEL RÍO PARRA 14

It is also worth noting that the case involves a "tension [...] between norms and exceptions. They need each other; they fuel each other" (Ginzburg xii). Compilations of case comparisons called collationes casuum proliferated during the Spanish Golden Age, particularly by Jesuit authors (Fernández Cano 493), and they had an appreciable influence on both the dramatic genre (Sullivan, Álvarez, Kallendorf and Gómez Canseco) and the prose of the time (Tierno Galván and Sánchez Jiménez). ${ }^{4}$

It should be remembered, on the other hand, that some critics view Mateo Alemán's Guzmán de Alfarache, the primary picaresque reference for La pícara Justina, as a work of a "consumado casuista" ("consummate casuistry"), in which "los predicados morales dependen del contexto" ("moral predicates are dependent on context") (Darnis 123, 124). Several crucial passages in Alemán's work could perhaps lend themselves to this conclusion. With respect to Guzmán's act, at the end of the book, of turning in a fellow sailor who plans to mutiny and seize control of the royal galley, Cavillac believes that it "se inscribe en la moral casuística" ("falls within the framework of casuistical morality", 122). Furthermore, the behavior of the picaro in said work, which Cavillac (161) likens to Alemán's own ideology, is consistent with both Machiavellian principles and Jesuit recommendations on this specific case. Similarly, the denouement of the novel Bonifacio y Dorotea contained within Guzmán, in which Dorotea decides to preserve her conjugal honor by hiding her rape at the hands of Claudio, is also in line with the conduct advocated by casuists to prevent an even greater ill (Cavillac 138). Other experts, such as Gómez Canseco (Alemán 2012: 59, n. 103), interpret some passages as critical of casuistry. Scholars are not, therefore, in complete agreement regarding Alemán's commitment to this mindset. In my view, which will be further developed in this paper, La picara Justina as a response to Guzmán de Alfarache necessarily entails a casuistical interpretation of Alemán's novel.

In sum, the preface of La pícara Justina conveys the idea that the writer has set himself an ambitious task of moral reformation which, inevitably, engages in an intertextual dialogue with Alemán's Guzmán de Alfarache and with its aim of "fabricar un hombre perfecto" ("creating the perfect man") (Alemán

4 For a clear, concise review of the evolution of casuistry and its influence on Spanish Golden Age literature, see Sánchez Jiménez (2014: 83-89). See also an early study by Caro Baroja. 
2014: 463). In this same preface, the implied author acknowledges that reading Guzmán led him to broaden the scope of his original plan. It remains unknown, however, to what degree he aims to reproduce the same rhetorical approach, nor do we know the extent of his admiration for this literary model. Following this clear explanation of its aim and significance, the book proceeds to Justina's autobiographical account. Nevertheless, contrary to the expectations created in the preliminary pages, the reader encounters a number of challenges with respect to extracting moral canons from the autobiographical incidents described, which go far beyond the types of interpretive exercises typically found in works intended for educational purposes. In this regard, it seems fitting to highlight a number of different circumstances, each of which will be addressed in its own respective section of this essay. All of them relate in some way to the elements involved in theological study of cases of conscience.

\section{Irrelevant Circumstances and Interpretations}

Although the preface urges the reader to interpret Justina's life in an exemplary light, most passages focus on inane events that are irrelevant for the purpose of exemplarity or for furthering the autobiographical account. We will also see that the preposterous life circumstances of the cases described claim such a disproportionate share of the narrative that they shift the discourse into the realm of parody. One example is found at the beginning of Justina's autobiography. The first topic addressed by our protagonist/narrator, with respect to which the picara adopts a descriptive and interpretive role, is highly frivolous. It revolves around a hair that has accidentally become stuck to the quill that Justina is using to write her memoirs. The irrelevance of the situation takes the aim of describing the protagonist's life circumstances to a ridiculous extreme, in what could be interpreted as a parody of the importance given by casuists to describing the minutiae of the cases they study. A prime example is the set of inquiries suggested in the Breue Compendio de Confessión, regarding "cuál, cuándo, por qué, en qué lugar, en qué tiempo, con qué instrumentos, por quién o contra quién pecamos y en qué, por cuánto, la cantidad del pecado o daño que se hace, si fuere poco o mucho, notable o no notable" ("what, when, why, where, at what moment, with what instruments, for whom or against whom we sin and in what way, to what extent, whether the degree of sin or damage done is small or large, noteworthy or unremarkable") (López de Alvarado 3). ${ }^{5}$

5 On confession manuals and treatises, see González Polvillo (253), who mentions another edition of López de Alvarado's work published in Rome in $155^{8}$. 
Thereafter, Justina lays out a complex set of scholarly examples for illustrative purposes. This interpretive exercise is also approached in a parodic fashion, given that it aims to shed light on an altogether banal occurrence. To this end, Justina draws a symbolic, presumably invented parallel between inconstant friendship and a duck, the animal from which her writing quill originated. Next, she begins a humorous tale of how Queen Isabel I uses a play on words to give King Fernando to understand that monarchs' secrets are impossible to conceal. She adds in two scholarly references. The first is classical in origin and describes Jupiter in the company of the celestial bodies, as evidence that the god is always visible. The second references the king's standard, envisioning it laden with the eyes of his subjects, as an example of the fact that monarchs' actions are always judged. From all of this, Justina deduces that she feels honored because although she is not royalty, her flaws and mistakes are made known by the hair in question. Justina herself ridicules the moral dimension ascribed to the banal situations she is involved in. Consider, for example, the passage in which her cousin reprimands her for making noise with some castanets briefly and almost unconsciously (433). The picara compares his overreaction to the details required in Inquisition cases to judge the severity of an offence. Passages such as this highlight the trivial events that make up Justina's autobiography and call into question the relevance of the exemplary function attributed to them in the preface. Such a critique of casuistry's concern with minutiae, even deploying them as a facile justification of questionable behavior, would later be expressed most famously in Blaise Pascal's judgement against the Jesuit "laxism" (Lettres provinciales 1657). Suffice the examples given thus far to give an idea of the exaggerated nature of the rhetorical process, evident in both the excessive number of examples cited and the grandiosity of the gods and monarchs used as a basis for comparison. ${ }^{6}$

From a hermeneutical perspective, there also is another important point. According to the preface, by making a special interpretive effort the reader should be able to discern the moral teachings concealed on the book's hidden level. On this level, however, the only thing the reader can make out is a complex jumble of erotic symbols. ${ }^{7}$

6 As Oltra (66) points out, this sharp contrast between the quality of the examples or points of comparison and the trifling purpose for which she uses them is one of the most characteristic rhetorical processes in the book's organizational structure.

7 One example is the erotic reading made by Garrote Bernal (224-225), who interprets as sexual references the terms tratar (have dealings with), pluma (quill) and pelo (hair) used in the passage in question. See also Dunn $\left(235^{-236)}\right.$. The same sort of reading has been made of other passages. Márquez Villanueva's work is a good example of this. 
The chapter devoted to the hair on the quill also contains an interesting rhetorical exercise consistent with casuistical practices. After spending several pages describing the trifling matter of the hair on the quill, Justina, who decides to address said quill as a silent conversational partner, admits the truth of the accusations of syphilis that the hair has supposedly thrown at her. Unexpectedly, and without enlightening the reader as to the relevant background events, she thus offers up information of key importance in her autobiography.

The interesting twist in this case is the way that Justina then attempts to dispel any guilt by presenting various mitigating circumstances to "señora pluma" ("Mrs. Quill"), who in a sense takes on an accusatory role. From this point on, the picara begins to express herself as if she were on trial, beginning her statements with the formula "Confieso ..." ("I confess ..."). In fact, the first thing she does is confess her culpability with respect to the accusations. However, the exaggerated number of formulas and plays on words she uses to paraphrase the fact that she has the disease progressively undermines the rhetorical effectiveness of the act of confession. Her statements thus cease to be interpreted as a gesture of humility or admission of guilt, and come to be construed as a display of literary conceptism that showcases the narrator's boastful character. Her rant ends with the following statement: "Concedo que soy pelona docientas docenas de veces" ("I concede that I am bald two hundred dozen times over", 207).

Justina then attempts to play down the importance of the disease, describing it as a very common illness, which to some extent dilutes her own culpability. Even so, once again this strategy of guilt avoidance loses its effectiveness by becoming a pretext to introduce a string of witty puns. The imagery employed, which would have had some degree of argumentative efficacy had it been used within reasonable bounds, becomes progressively ludicrous. Eight rhetorical questions are posed in total, one after another, to the point where the redundancy and the ridiculous formulations employed render the device wholly useless.

The next of the extenuating circumstances outlined by the picara is the fact that her confession, made voluntarily, if not vaingloriously, could prevent others from falling ill, with the inference that she is performing a good deed. To make this point, Justina embarks on a long declaration in which she insists that she has no reason to be ashamed of her illness, or of having gone bald because of it. To strengthen the weight of her argument, she illustrates her fortitude in the face of her illness and baldness by means of a fable. She tells of the frog, said to have once had hair, who was jealous of the swan's song and the fly's 
peaceful sleep in the winter, and asked Jupiter for both abilities. In exchange for the loss of the frog's hair, the god gave it a pillow and a hairy tongue so it could sleep and sing like the animals it envied. If the fable itself is nonsensical, the way it is applied is even more so. Justina concludes that it shows that while healthy people are at mass listening to sermons, those with syphilis stay asleep. She also uses it as proof that those with syphilis have the gift of gab, like the frog after it was granted its new tongue.

She wraps up her arguments by claiming that she is, figuratively speaking, akin to a preacher who stands at the hangman's noose, and affirms that she can only be condemned by unspiritual people who refuse to see an example in her case (214). This is, therefore, an example that merits consideration within the framework of theological casuistry. Nevertheless, despite the extenuating circumstances which Justina believes make her case an example of virtue, the arguments she sets out are plainly ludicrous and lacking in logic and rationality. ${ }^{8}$

This same rhetorical process is used in other passages of the work, enabling the reader to perceive easily the automated, ineffective mechanisms Justina employs to construct exculpatory discourses. One example is the last of the "books" that make up the work, in which the picara describes inheritance issues and money-related lawsuits with her relatives. The first thing she sets out to do is discredit the other party, represented by her siblings. She thus brands them as "crueles enemigos" ("cruel enemies", 842) and describes her sisters as "adversarias" ("adversaries", 843). According to Justina, the other women's dislike for her is rooted in the same instinct that makes a bully attack those who stand out for their intelligence. After these reflections, to illustrate the crux of her argument she draws on her usual barrage of examples, which are once again applied with an absurd logic that undermines their argumentative efficacy. To corroborate the supposed parallel to Justina's relationship with her siblings, she recounts the familiar tale of the elephant harassed by mice. According to the picara, the mouse chases the elephant due to the aversion that a creature supposedly born of corruption, the mouse, has for a creature distinguished by a tendency to fall in love and procreate. Once again, the arguments she lays out are humorous and lacking any logical basis, which invalidates the rhetorical strategy she uses to defend herself against the accusations.

In sum, everything seems to indicate that the ultimate aim is to use Justina's character to deride the formulation of complex, contrived rhetorical arguments, which are employed to substantiate potentially extenuating circumstances for

8 As, in other context, Dunn explains: "Narrative logic is suppressed [...]. The consistency of the scene depends solely on Justina's aesthetic of verbalized comic surprise" (240). 
the acts of which Justina has been accused. In my view, in the passages cited above the primary parodic targets are the argumentative procedures used to justify conduct that would be classed, a priori, as reprehensible according to the moral stance adopted in the preface. In addition to the examples given, there are two passages in La pícara Justina which Gómez Canseco (168) points to as burlesque examples of casuistical justification of theft and usury, respectively: "Señor talego, digo teólogo, no niego que burlas con la bolsa traen consigo carga de restitución. Bien sé que es gran pecado, pero [...] no hay pecado más escusable que aquel que procede de la necesidad de comida y sustento" ("Mr. Talego [literally, 'corpulent person' and also 'sack', used mockingly here due to its similarity to teólogo (theologian)], I mean theologian, I don't deny that tricks of the purse bring with them a duty of restitution. Well I know it is a great $\sin$, but $[\ldots]$ no sin is more forgivable than one rooted in the need for food and sustenance", López de Úbeda 783-784); and

[...] es como caso de conciencia en materia de restitución puesto por boca del mismo mercader interesado, que lo afeita de manera que, si encuentra un nuevo teólogo [...], no solo le tumbará, pero harale parecer que un promontorio de injusticia es monte de piedad, y una manifiesta usura es una variedad heroica

it's like a case of conscience on the subject of restitution that is placed in the mouth of the very merchant it concerns, who embellishes in such a way that if he finds a new theologian [...], he will not only defeat him but also make a hill of injustice seem like a mountain of piety, and manifest usury a type of heroism. $(864-865)^{9}$

Let us consider one of the short stories narrated by Justina, who tries to illustrate how those who write about their own lives can fall prey to misrepresentation. It is about a humble tailor who manages to amass a fortune and decides to change his surname to Pimentel, to appear to be of higher social standing. He also orders a carved stone coat of arms depicting scallop shells, the Pimentel family emblem, to hang on the door of his home. The case is brought to the authorities and the tailor is ordered to either remove the coat of arms or appear before the judge to declare why he appropriated the Pimentel insignia. He gives three reasons, each more absurd than the last. First, he argues that

9 For an interpretation of this passage in its sociocultural context, see Del Río Parra (128). 
the stonemason simply did the job that the tailor commissioned him to do. Second, he contends that he incurred financial costs in order to produce the coat of arms. Finally, he argues that his decision to include the shells was a tribute to the many shells he carried back in his hat from pilgrimages made to Santiago de Compostela, because the charity he received on the pilgrimages made him rich. With respect to the last argument, he notes that it would be heresy to oppose an act performed out of devotion, for which reason the judge, who is a "cristiano temeroso" ("God-fearing Christian", 315), decides to exonerate him, and the tailor receives legal permission to impersonate the Pimentels.

The tale is a ridiculous and, in my view, conscious application of casuistry, which uses the "doctrine of mental reservation" to legitimize the telling of halftruths when the declarant's background situation is complicated, as Somerville shows. Mateo Alemán himself explicitly legitimizes opportune silencing of the truth, which he justifies by means of an allegory. The first part of Guzmán de Alfarache tells of how The Truth, after being taught a lesson by the harm resulting from uncovering falsehoods, decided to pretend to be mute to avoid future injury (Alemán 2014: 317-320). ${ }^{10}$

Both the tailor's arguments and the judge's verdict have a clearly parodic dimension, as does the fact that Justina uses this example to justify the stance she takes when narrating her life. She clarifies that the tale has been included in reference to the inclination toward falsifying facts that supposedly befalls those who write their own memoirs. However, after recounting the tale, in which the lying tailor emerges victorious by appealing to the sort of arguments that characterize casuistry, Justina identifies with his fraud and comments that both of them are, figuratively speaking, from the same province of Picardia ("Cunning"), that is, that they make a show of their deceptions whenever possible.

The narrative fallacy that Justina boasts of in this passage is a practice seen repeatedly throughout the work, which she employs when recounting her own experiences as well as in biographical descriptions of her ancestors. In the style of the most representative picaresque novels, Justina summarizes the lives of her parents. In a clearly parodic application that exaggerates the genre's characteristic features, however, she also includes an entire litany of biographies of her grandparents and great-grandparents, which serve an essentially comedic purpose.

Employing the same sort of procedure as that used by the fraudulent tailor, she describes as virtuous qualities certain flaws that could be pointed to in her ancestors. Her mother, for example, she describes as compassionate to

10 For a study of lies in the picaresque novel, see Dueñas, who draws a connection between this passage from Guzmán de Alfarache and casuistry (109). 
the poor, a conclusion justified by Justina's memories of how she forbade poor people to enter her inn with the alleged intention of preventing the suffering of those who didn't have enough money to cover their expenses (376). With respect to her father, after listing a vast number of strategies (most of them fraudulent) which he used to gain the highest possible profit from customers at the inn, Justina identifies his most prominent traits as discretion, erudition and masterful skill (371). In a sense, the father does possess these qualities, but Justina ignores the fact that these three traits are typically used with virtuous intent rather than for personal gain.

On this point, I would be remiss not to mention Guzmán de Alfarache's casuistical defense of the thefts committed by his father. With the aim of justifying them, he argues that although his father stole other people's property several times, he himself was also a victim of robbery. Guzmán also adds - broadening the scope of his reasoning to encompass all merchants in general - that only confessors have the right to hear the facts, and only God the right to judge their guilt (Alemán 2014: 50).

The narrative strategy of dressing up flaws as virtues, which could be viewed as a burlesque replica of casuistical practices, is not exclusive to La picara Justina. Among the many parallels between this work and Quevedo's El Buscón are several passages that employ very similar procedures. ${ }^{11}$ Another prime example is a passage from the famous liberation of the galley slaves by the character Don Quijote, who uses indirect language to interpret the crimes that have been reported to him in a positive light, relegating to a secondary position the true reasons that the prisoners were sentenced. ${ }^{12}$ As Close points out, Don Quijote's act of taking justice into his own hands and setting the delinquents free is based on "a world-upside-down view of the relation of prisoners to the

11 The protagonist's father, Clemente Pablo, is described as a person "de buena cepa" ("from good stock"), that is, noble. We also see, however, a playful ambiguity arising from the word cepa, which also means "grapevine", in an allusion to his excessive taste for alcohol (Quevedo 55). Similarly, when introducing Aldonza de San Pedro, the picaro's mother, the fact that she has few enemies is highlighted as a positive trait, but immediately afterwards it is mockingly noted that not even "los tres del alma" ("the three of the soul", $5^{6}$ ) number among them, that is, the world, the devil and the flesh. Along the same lines, the expression "persona de valor" ("person of value") conceals a malicious reference to her status as a woman who can be bought for a sum, or a prostitute. Furthermore, it is said that Pablos de Segovia's brother "robaba a todos las voluntades" ("stole everyone's hearts", 56), a description that ironically praises his affable nature while alluding to his skill as a thief even at the tender age of seven years old.

12 Here, and in other examples that draw on criminals' slang, those who steal other people's property are classed as lovers, and those who confess their crimes as songbirds, or singers (Cervantes 259-260). 
law underpinned by a casuistical pun" (15). Incidentally, the galley slave who features most prominently in the tale, Ginés de Pasamonte, could be considered a burlesque of Guzmán de Alfarache's character. This, in turn, could be interpreted as Cervantes' response to the casuistry that some might ascribe to Alemán's work. ${ }^{13}$

\section{$5 \quad$ Nullification of the Implied Author's Perspective}

As we have seen, despite the apparent soundness and schematism of the explanations provided in the preface, a number of issues arise when reading the work which progressively undermine the relevance and authority of the implied author's initial statements. It should also be noted that the implied author's voice, which we hear throughout the work by means of observations made at the end of each chapter, does not always focus on Justina's actions. The comments at the end of the chapters about a group of students called "La Bigornia" ("The Anvil"), for example, only censure the conduct of said group, which kidnaps Justina. There is no censure of Justina, who rejects her abductors from start to finish and emerges victorious from her dangerous encounter with them. These chapters thus leave the reader with an impression of the character's pre-eminence with respect to the implied author's voice, whose significance pales in comparison to the prominence attained by Justina in terms both of the action and of passing judgment on the deplorable conduct of her abductors.

Another notable example appears in Chapter 3 of Book III, entitled "De la vieja morisca" ("The Old Moorish Woman"), in which the implied author's final comment adopts a stance similar to the critical tone used by Justina

13 With respect to another prisoner who appears in this tale, accused of maintaining incestuous relations, Redondo (242-244) points to a possible Cervantine parody of casuistical cases of conscience on the subject of incest. For his part, Gómez Canseco (168, n. 5) observes a clear burlesque allusion to casuistry in Don Quijote, when the barber, Master Nicholas, uses the following words in an attempt to allay Sancho's fears that his master may wish to enter the clergy: "[...] rogaremos a vuestro amo, y se lo aconsejaremos y aun se lo pondremos en caso de conciencia, que sea emperador y no arzobispo" (“[...]we will entreat your master, and we will advise him, even putting it to him as a case of conscience, that he should become an emperor and not an archbishop.") (Cervantes 325-326). See also Michael Scham's work in this volume. On a related note, Gómez Canseco argues that Cervantes devised the plot of La Gran Sultana within the framework of casuistry. Further relevant observations are made by Sáez (6) regarding the play Pedro de Urdemalas. 
to describe the Moorish witch. Consequently, the differences between the character's perspective and that of the author largely disappear.

In some cases, Justina's character takes over the role of the implied author's voice in guiding readers to interpret the work correctly, as in the passage where she notes that "lo bueno se tome por veras, y lo que no fuere tal, pase en donaire, porque lo contrario sería sacar de las flores veneno" ("the good must be taken for truth and what is not good as a joke, as to do otherwise would be to draw poison from flowers", 736). The functionality of these sorts of observations is undermined by placing them in the mouth of a narrator who lacks credibility. The functions attributable to the implied author's voice are therefore nullified by the overwhelming presence of Justina, a manifestly deceitful character. As Friedman notes, "[w]hile the author has the last word in each section, Justina has the major voice" (88).

Even more interpretive difficulties arise if we consider the confusion caused by the division of the functions attributable to the narrative voices of the author and the protagonist, which aren't always easily reconciled with the explanations given in the preface. In this respect, it should be noted that the implied author's comment at the end of Chapter 4 of Book IV doesn't address the specific circumstances of said chapter:

Una mujer libre a la misma Iglesia santa pierde el respeto y en ella se descompone, porque quien niega a Dios la posada de su alma y la tiene tan en poco que, de casa de Dios, la hace de demonios, tampoco atiende cuán digno es de suma reverencia aquel divino templo en que Dios está real y verdaderamente

An unconstrained woman has no respect even for the Holy Church, and inside it she loses her composure, because those who deny God lodging in their soul and hold it in such little regard that from the house of God, they turn it into a sty for demons, are also unable to see how worthy of utmost reverence is that divine temple wherein God really and truly resides. $(956)$

Indeed, the shifting of the events narrated in this chapter to the wholly theological sphere involves such reductionism that the scope of its application is almost marginal. In any event, the comment seems to have been written independently from the development of the plot, and to limit itself to highlighting a point that is nothing more than anecdotal in the context of the chapter and the work in general. 
It is also worth noting that some of the work's marginal notes distance themselves from the implied author's voice. One example is the one that tells us that the author is angry at the character of the old Moorish woman and is thus making a pretense of his reluctance to write in verse the summary preceding the chapter about her (869). We are thus led to infer the existence of a different narrative level superior to that of the implied author, which increases the complexity of interpreting the text and relativizes the exemplary aspirations stated in the preface. Other notes, moreover, refer to passages from Justina's autobiography. One example is found in the chapter of her account that contains the following marginal comment: "A propósito de la mancha de la saya, prosigue artificiosamente el autor la introducción de su libro" ("In relation to the stained tunic, the author skillfully continues the introduction to his book", 223). Later on, also in relation to Justina's remarks on the book's intent, we find these two notes: "Intento del autor en su libro. Es desengañar ignorantes" ("Intention of the author in his book. Is to enlighten the ignorant", 253). We see, then, that this superior narrative level, which peeks out from the marginal notes, refers to the voices of the protagonist and the author as a single entity, serving to undermine the privileged role adopted by the implied author's voice in the preface.

\section{$6 \quad$ Purpose of the Casuistical Approach and the Originality of La pícara Justina}

The casuistical approach used in La picara Justina, which is executed in an exaggerated fashion lacking in functionality, could be interpreted as a means of taking Alemán's depiction of moral reform based on the life of a rogue to its very limits, with a clearly parodic intent. In my view, the aim is not to negate the value of exemplary literature. The work calls into question the use of the humble figure of the rogue as a means of conveying moral teachings. Underpinning the ludicrous and merciless parodic development of La picara Justina is a criticism of Alemán's break with the conventions of literary decorum which, just as Lope did with respect to comedias, initiated a complete renewal of literary conventions (Mañero Lozano 2009 and 2017, on the respective authors).

At the opposite pole, La picara Justina is a reaction to Alemán's narrative innovations. The contributions of the work are not, however, restricted to the moral level that underpins its rejection of Alemán's formula. As in Don Quijote, which manages to create a universe independent from books that parody chivalry, La pícara Justina transcends mere parody and offers an extremely original 
pursuit of a pure class of fiction that is also independent of treatises on moral theology. Among other innovations, it creates multiple narrative voices with their own identities which claim an independent space within the fictional work, serving to drive forward a process of literary experimentation unconstrained by moral didacticism.

\section{Acknowledgements}

This study is part of the Spanish Ministry of Science, Research and Universities' R\&D Excellence Project (reference: FFI2017-82344-P), funded by the Spanish National Research Agency (AEI) and the European Regional Development Fund (EDRF). It is also one of the activities funded by the HUM-78o Research Framework ("Hispanic Literature Studies of the University of Jaén"). I would like to thank Marlen Bidwell-Steiner, Michael Scham and David González Ramírez for their constructive observations regarding this paper.

\section{Works Cited}

Alemán, Mateo. Guzmán de Alfarache. Ed. Luis Gómez Canseco. Madrid: Real Academia Española (Biblioteca Clásica, 42), 2012.

Alemán, Mateo. Guzmán de Alfarache Iy II. Ed. David Mañero Lozano. Obra completa, 3 vols. Eds. Pedro M. Piñero Ramírez and Katharina Niemeyer. Madrid-Frankfurt am Main: Iberoamericana/Vervuert - Junta de Andalucía - Universidad de Sevilla, 2014.

Álvarez, Miguel. El probabilismo y el teatro español del siglo XVII. Unpublished doctoral thesis. New York: New York University, 1982.

Caro Baroja, Julio. “Probabilidades, laxitudes y corrupciones.” Las formas complejas de la vida religiosa: Religión, sociedad y carácter en la España de los siglos XVI y XVII. Madrid: Akal, 1978: 517-55o.

Cavillac, Michel. "Guzmán de Alfarache" y la novela moderna. Madrid: Casa de Velázquez, 2010.

Cervantes, Miguel de. Don Quijote de la Mancha. Ed. Francisco Rico, in collaboration with Joaquín Forradellas. Barcelona: Círculo de lectores/Centro para la Edición de los Clásicos Españoles, 2004.

Close, Anthony. "The Liberation of the Galley Slaves." Cervantes 27.1 (2007): 12-30.

Darnis, Pierre. "Guzmán de Alfarache, la paradoja del mentiroso y los mundos posibles del lector." eHumanista 34 (2016): 105-133. 
Del Río Parra, Elena. Cartografías de conciencia española en la Edad de Oro. Mexico: Fondo de Cultura Económica, 2008.

Dueñas, Rafael Antonio. De pícaros y mentirosos en la novela picaresca española del Siglo de Oro. Doctoral Dissertation. Stony Brook University, 2014.

Dunn, N. Peter. “Rogue Females.” Spanish Picaresque Fiction. A New Literary History. Nueva York: Cornell University Press, 1993: 232-251.

Fernández Cano, Antonio. "La casuística: un ensayo histórico-metodológico en busca de los antecedentes del estudio de caso." Arbor 171.675 (2002): 489-511.

Friedman, Edward H. "The Voiceless Narrator: the Spanish Feminine Picaresque and Unliberated Discourse." The Antiheroine's Voice: Narrative Discourse and Transformations of the Picaresque. Columbia: University of Missouri Press, 1987: 69-118.

Garrote Bernal, Gaspar. "A pelo y a pluma: algoritmos de conceptos en Castillejo y 'La Pícara Justina.' (Con una digresión para uso de cervantistas)". Cervantes y su tiempo. Eds. Juan Matas Caballero and Balcells Domench, Jose María. Coord. Desirée Pérez Fernández. León: Universidad de León, Secretariado de Publicaciones, 2008: 207-232.

Ginzburg, Carlo. "Preface." A Historical Approach to Casuistry. Norms and Exceptions in a Comparative Perspective. Eds. Carlo Ginzburg and Lucio Biasiori. London/New York: Bloomsbury, 2019: xi-xx.

Gómez Canseco, Luis. "Probabilismo en Cervantes: La gran sultana como caso de conciencia." Criticón 109 (2010): 167-186.

González Polvillo, Antonio. Análisis y repertorio de los tratados y manuales para la confesión en el mundo hispánico (ss. XV-XVIII). Huelva: Universidad de Huelva, 2016.

González Ramírez, David. "La novela corta del Siglo de Oro en tela de juicio: la ejemplaridad y su función retórica (a propósito de la tradición medieval, los novellieri y las Novelas ejemplares de Cervantes)." eHumanista/Cervantes 6 (2017): 56-92.

Kallendorf, Hilaire. Conscience on Stage. The Comedia as Casuistry in Early Modern Spain. Toronto: University of Toronto Press, 2007.

López de Alvarado, Garci. Breue compendio de confessión. diuidido en quatro capítulos. a honrra de dios y vtilidad de todo fiel christiano. Venice: Giouanmaria Bonelli, $155^{2}$. López de Úbeda, Francisco. Libro de entretenimiento de la pícara Justina. Ed. David Mañero Lozano. Madrid: Cátedra (Letras Hispánicas, 707), 2012.

Mañero Lozano, David. "Del concepto de decoro a la «teoría de los estilos»: consideraciones sobre la formación de un tópico clásico y su pervivencia en la literatura española del Siglo de Oro." Bulletin Hispanique 111.2 (2009): 357-385.

Mañero Lozano, David. "Tragicomedy and Literary Decorum: Theoretical Foundations of the «Third Dramatic Genre» in the Origins of Spanish Theater." Iberoromania 86 (2017): 151-172. 
Mañero Lozano, David. "Los sueños de Proteo. De Lázaro de Tormes al Pijoaparte de Marsé." Estudios culturales y literarios del mundo hispánico. Madrid: CSIC, 2021.

Márquez Villanueva, Francisco. "La quinta langosta de La pícara Justina." Boletín de la Real Academia Española 79 (1999), 278: 355-376.

Maryks, Robert A. Saint Cicero and the Jesuits: The Influence of the Liberal Arts on the Adoption of Moral Probabilism (Catholic Christendom, 1300-1700). Aldershot: Ashgate, 2008.

Oltra Tomás, José Miguel. "La casuística estructural en La Pícara Justina, de Francisco López de Úbeda." Estudios Humanísticos 5 (1983): 55-67.

Quevedo, Francisco de. La vida del buscón. Ed. Fernando Cabo Aseguinolaza. Barcelona: Crítica (Biblioteca Clásica, 63), 1993.

Redondo, Augustin. "Los amores burlescos en el Quijote." Cervantes 27.1(2007):227-248. Sáez, Adrián J. "Elementos religiosos en Pedro de Urdemalas." e-Spania 18: 1-11.

Sánchez Jiménez, Antonio. "Los casos de conciencia en la novela pastoril del Siglo de Oro: casuismo y probabilismo en la Arcadia (1598) de Lope de Vega." Revista de literatura 76.151 (2014): 79-100.

Sommerville, Johann P. "The «new art of lying»: equivocation, mental reservation and casuistry." Conscience and Casuistry in Early Modern Europe. Ed. Edmund Leites. Cambridge: Cambridge University Press, 1988: 159-184.

Sullivan, Henry W. "Moral Probabilism and Casuistry in Spain during the Counter Reformation." Tirso de Molina and The Drama of the Counter Reformation. Amsterdam: Rodopi, 1976: 40-51.

Tierno Galván, Enrique. “Introducción.” Baltasar Gracián, El político. Ed. Evaristo Correa Calderón. Salamanca/Madrid: Ediciones Anaya, 1961: 4-14.

Vereecke, Louis-Gustave. "Casuistique." Encyclopcedia Universalis, 2019. Web. July 25 202O. URL: http://www.universalis.fr/encyclopedie/casuistique/. 


\title{
The Exploration of Circumstance: Casuistry and the Emergence of the Novela Bizantina in Alonso Núñez de Reinoso's Historia de los amores de Clareo y Florisea, y de los trabajos de Ysea (1552)
}

\author{
Anita Traninger
}

\begin{abstract}
Despite being variously referred to as a romance of love and adventure, the Golden Age novela bizantina is hardly limited to narrating amorous exploits. Rather, it tends to treat of displacement and destitution, thereby confronting its characters with existential cases of conscience. This article explores how the first Spanish novel of this kind, Alonso Núñez de Reinoso's Los amores de Clareo y Florisea y los trabajos de la sin ventura Isea (1552) engages its readers in moral reflection.
\end{abstract}

\section{Keywords}

Núñez de Reinoso - Greek novel - novela bizantina - Achilles Tatius - casuistry Second Sophistic - Venice - Sephardic jews - diaspora

The so-called novela bizantina, which is the early modern Spanish-language appropriation of the Greek prose novel, has not yet been connected with casuistry or thinking about cases in general. ${ }^{1}$ This may have to do with the genre's reputation as idealizing romance, offering schematic sentimental plot lines that do not betray an interest in human psychology or moral crisis. The stories of virtuous and chaste lovers separated by shipwreck, pirates, abductions and mock executions, eventually reunited unscathed, inspired Mikhail Bakhtin's concept of the chronotope and more specifically that of adventure time. And they were of course relentlessly mocked by Voltaire in his Candide. But they have not been construed as vehicles of moral reflection.

1 I gratefully acknowledge the funding received from the German Research Association (DFG) in support of the research for this chapter in the framework of the research group FOR 2305 "Discursivisations of the New" at Freie Universität Berlin. 
The very first exemplar of the emerging genre set the tone for subsequent texts, despite mixing several generic traditions and being not at all typical of what would become the novela bizantina. It does, however, lead the way in accommodating moral philosophical concerns, both by raising them in the paratexts and by staging them in the narrative. Alonso Núñez de Reinoso, a Portuguese converso in Venetian exile under the protection of the powerful Mendoza/Nasi family, which at the very time sponsored the exodus of thousands of Sephardic Jews to the Ottoman empire, ${ }^{2}$ published the Historia de los amores de Clareo y Florisea, $y$ de los trabajos de Ysea in Venice in 1552. The novel's dedicatee, Juan Micas - who would later, under the name of Joseph Nasi, become the duke of Naxos - was already installed at Constantinople when Reinoso wrote the book. He had closed a deal with the Sultan to let the Portuguese conversos who had reached Venice with the help of his family (and in particular his aunt, Gracia Mendes, also known as Beatriz de Luna), migrate to the Ottoman Empire. In a letter by Felipe II dating from October 1569 he was later declared an enemy of Christendom (Teijeiro Fuentes 1991: 59). Against this backdrop, the predominant reading of Reinoso's novel is that of an ego document, a "fictional journal which is the factual catalogue of his misfortunes" as Constance Hubbard Rose put it (Rose 1983: 102). Isea, the strange third character alongside the conventional virtuous couple, has variously been construed as Reinoso's persona, not only as a narrative device, but as a stand-in for his real-life experience that is allegedly allegorised in the story. ${ }^{3}$ Reinoso's situation as a Portuguese converso in Venetian exile seems to suggest that the text is an echo of a personal experience of displacement and deprivation.

Reinoso's bibliography is short. Apart from Clareo y Florisea, there is only a collection of "obras en verso" which were appended to the novel as the second part of the volume. Hence the full title: Historia de los amores de Clareo $y$ Florisea, $y$ de los trabajos de Ysea: Con otras obras en verso, parte al estilo Español, y parte al Italiano: agora nuevamente sacada a luz. The octavo volume, extending to no more than 200 pages for the novel and 136 for the coplas castellanas y versos al estilo italiano, was printed by Gabriel Giolito de Ferrari and his brothers - once, as there is no evidence of further editions. An apology that follows the Italianate, yet Castilian coplas points to the community of strangers involved in the production of the book, with Venetian typesetters composing a Castilian text: "Y siendo los que componian, estrangeros, y poco platicos en la lengua Castellana, no podra dexar de auer yerros de letras, que faltarean o sobraran, o estaran puestas unas por otras [...]" (Núñez de Reinoso II, 135). The

2 For this context, see Grunebaum-Ballin; Saporta Beja; Rose 1970.

3 For this substitute function see in particular Bataillon. 
diverse group that produced the volume is indicative of the lively and international intellectual milieu in which the traditional love and adventure story became tied to moral philosophical concerns.

\section{A Tale of Love and Loss}

The title page, presenting Clareo and Florisea together with a certain Isea as protagonists, as well as the header for the story, which eventually not only names Reinoso as the author but which also characterises Isea as "sin ventura" (65), appears to point to a love triangle, a story of love and jealousy. And indeed, in chapters one to nineteen, this is exactly what unfolds. Clareo, a native of Constantinople, falls in love with his niece Florisea. They flee towards Alexandria and, despite being madly in love, remain chaste as if they were (close) siblings (this being a motif taken from Heliodorus, see Marguet 14). In Alexandria, Florisea is abducted by a pirate, who appears to decapitate her and throw her lifeless body into the sea. Isea, a nineteen-year-old widow, falls in love with the now single Clareo. Her name is a truncated version of her beheaded predecessor; she is a "de-flowered" Florisea. Clareo, after much wooing by Isea, who has fallen helplessly for him, eventually consents to marriage under the condition that it must not be consummated. They decide to sail to Ephesos, Isea's hometown, where she buys a female slave, not being aware that she is none other than Florisea (who is not dead after all). Also, Tesiandro Isea's husband, whom she had also thought dead - returns and falls in love with Florisea. For some reason Clareo, unaware of these events, confesses that he had murdered Florisea. The Ephesians sentence him to death, but Florisea appears in the nick of time and saves him. Clareo and Florisea get married and return to Byzantium.

This is the end of the 'classical' Greek tale, but it is not the end of the story. While the reunited couple takes off to live happily ever after, it is Isea who is left behind. She decides that it is time for her to leave home, to roam the world and find the place in which death would finally release her from her pain ("e irme por ese mundo hasta ver en qué lugar la muerte querría acabar mi vida, y las duras parcas cortar los hilos de la triste tela, y la dura tierra querría recoger este mi cansado cuerpo," 137).

Thus commences the second part, which sees Isea again heading towards Alexandria, where she encounters a knight errant who inexplicably travels in full armour on a black horse, accompanied by four valets carrying his weapons (144). He is Felesindos de Trapisonda, the nephew of the Emperor of Trebizond and son of the former King of Bohemia. Surpassing Ulysses, as the novel claims, 
he has been on the road for many years in search of the princess Luciandra with whom he is in love and who had disappeared from court without a trace. The following ten chapters detail a sequence of knightly pursuits. While Isea, who is the story's first-person narrator, is present per conventionem, she is a virtually invisible observer in these episodes. After a long series of adventurous (but eventually pointless) pursuits, Felesindos - who by now calls himself "el caballero de Esperas Dudosas" (171) - is invited by servants of Venus and Pallas to a battle of the goddesses in Argos, a battle in which all the great caballeros of the world are supposed to take part (173). The two goddesses give speeches to convince the assembled knights to fight for their respective side. Felesindos is of the smaller group who decides to join Venus' army; they are immediately at a disadvantage, not only because of their numbers, but because the army of lovers "peleaban muy flacamente" (177). In a last-minute relief campaign, more knights, "todos armados al hábito pastoril" (177), are brought in for Venus' side, which eventually wins.

Felesindos and Isea march on towards the "casa de la fama", "la cual está en una región entre el aire y el cielo y el mar” (179), a borrowing from Ovid's Metamorphoses (XII, 39-40), and then to the "casa del gran sabio," "la cual estaba metida entre altas sierras y montes" (183). The wise man leads them to the río del olvido, telling them that if they drink from its waters, all their sorrows will be erased. Both decline. After a detour to the underworld, where Pluto reigns (185) - Isea again not engaging with her company, but rather muttering her observations to herself ("decía conmigo misma", 187 ; "decía yo conmigo", 188) - the wise man sends Felesindos off to the casa del Descanso where he will find Luciandra. After a tearful goodbye, Isea and Felesindos part ways. She sets her mind on becoming a nun and heads towards Europe. After being rejected from a monastery in Spain because of her lack of financial means, she moves on in search of a tranquil place to write her memoirs. As she reaches the insula Pastoril, she is seen, in a metaleptic leap, turning to writing the very book the reader is about to close.

In contrast to Clareo and Florisea's exemplary tale of separation and reunion, Isea's story is framed as a case. Her life is narrated as a series of situations that require judgement and decision; it is not presented as an exemplum, a narrative that details and evidences virtuous and thus exemplary behaviour. What is specific about the form of the case, as André Jolles put it, is that "while it asks the question, it cannot give the answer. It imposes on us the duty of making 
a decision but does not offer the decision itself - what manifests itself in the case is the pondering, but not its result." ("Das Eigentümliche der Form des Kasus liegt nun aber darin, daß sie zwar die Frage stellt, aber die Antwort nicht geben kann, daß sie uns die Pflicht der Entscheidung auferlegt, aber die Entscheidung selbst nicht enthält - was sich in ihr verwirklicht, ist das Wägen, aber nicht das Resultat des Wägens," Jolles 158).

Reinoso writes on the threshold of what has been called casuistry's "cen-

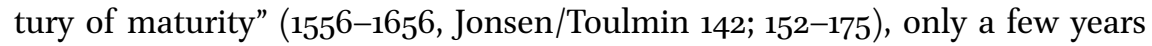
after the Council of Trent instigated intense publication activity in the field of casuistry. In the Christian context (into which Reinoso had been forced as a converso), casuistry had emerged from the practice of confession. With the requirement of annual confession for all believers called for by the Papal bull Omnis utriusque sexus in 1215, the confessor emerged as a distinct figure, mediating between the parish flock and church authority. Invested with the institutional power to execute performative acts such as eucharistic consecration, imposing penance and granting absolution, his high moral rank conflicted with the often limited learning of the priests of lower hierarchical orders. As confessors were typically not experts in the highly specialized discourse of theology and the pertinent modes of reasoning, a genre of manuals, the so-called summae confessorum, emerged, with the Summa de poenitentia by Ramón de Peñafort (1175-1275), dating from 1221 (not printed before 1603 , but available in a host of manuscripts), being held as the architext of the genre. It was followed by a sea of summae which typically had technical titles like "Summa de casibus conscientiae", but were generally known under nicknames derived from the names of their authors - Raymundina, Astesana, Pisanella, Rosella, Baptistina, Tabiena, Monaldina, Sylvestrina, etc. This is testimony to their popularity, as are the many surviving copies (cf. Michaud-Quantin). These handbooks were supposed to enable a confessor to recognize sins and to judge them, to know whether they were to be considered venial or mortal, and if so, under which circumstances. In order to help him with this task, dubious cases and their solutions were collected first alphabetically and then shifted to a thematic order in the fifteenth century, variously following the seven capital sins or the Ten Commandments (Jonsen/Toulmin 153). But while Christian thinking in cases was nearing its apogee, the novela bizantina was only about to take shape.

\section{$3 \quad$ An Emerging Genre}

The early modern history of the Greek novel has frequently and predominantly been framed as the reception of Heliodorus' Aithiopika. In the last few 
decades, valuable efforts have been made at mapping the transformations and adaptations of the Heliodoran scheme. Much of the critical attention has been focused on Cervantes' Los trabajos de Persiles y Sigismunda (1617), while his eternal competitor Lope de Vega's El peregrino en su patria, published more than a decade earlier in 1604, is only gradually being recognized as the decisive innovation that it was. Beyond individual imitatio and aemulatio, however, there seem to be patterns of engagement with the ancient models that yield widely different results. While the Spanish novela bizantina, for example, tends to be set in contemporary Spain and presents melancholic, if not pessimistic scenarios of displacement and destitution, the French roman héroïque is concerned with a heroic antiquity. In the transcultural and transnational networks of writers, readers, buyers, translators, printers and impresarios, different poetological and literary contexts informed very different re-imaginations of the genre.

At the same time, the focus on Heliodorus privileges only one of the five known ancient authors of prose novels, thereby losing sight of another significant work equally known to early modern Europe, Achilles Tatius' Leucippe and Cleitophon. The first Greek-style novel in the Castilian language, which will be the focus in this chapter, was indeed not an imitatio of Heliodorus but rather a creative appropriation of Achilles Tatius' novel in eight books dating from the second century AD. It is fair to say that Heliodorus and Achilles Tatius belong to what could be termed 'the other' classical tradition, the tradition stemming from the Second Sophistic that also includes declamation and paradoxical encomia. The ancient prose novel is a blind spot within this neglected tradition, and even lacked a name: as Carlos García Gual has pointed out, despite producing literary terminology for tragedy, comedy, lyrical poetry, philosophy, historiography, biography, the epic, and more, neither the Greek nor the Roman culture felt a need to give a name to the prose novel, and much less to address it in their poetics (García Gual 16; Morgan 176-177 and the critical discussion in Goldhill). When these texts eventually became models for imitation in the early modern period, the genre was still unnamed.

Despite building on Achilles Tatius, Reinoso did not imitate his model faithfully, which is partly due to the fact that he modelled his narrative on an Italian translation of books $5^{-8}$ only. These had been published in Venice in 1546 under the title Amorosi ragionamenti by Lodovico Dolce, a Venetian humanist and editor in the service of Gabriel Giolito's press. ${ }^{4}$ But Reinoso went even

4 Zimic claims that Reinoso was familiar with the full text and feigned his debt to Dolce. He argues that Reinoso's chapter 20 shows parallels with Achilles Tatius' third book. See also Teijeiro Fuentes (1984) for more supposed traces of Achilles Tatius' chapters I-IV in Reinoso. 
further and reimagined the genre, responding to contemporary concerns and opening up new perspectives for generations to come. As has become evident, Reinoso strays quite far from Tatius' Leucippe and Cleitophon, adding, in the second part, seminal elements from the early modern European literary imaginaire, from knights errant and fighting gods to pastors and nymphs. Reinoso claimed that it was his intention to write "imitando y no romanzando" (65), taking Dolce's Amorosi ragionamenti as an inspiration rather than faithfully translating it into another vernacular. As we have seen, this is exactly what he did, at the same time cutting the learned digressions (Cruz Casado 1994: 26; Menéndez Pelayo II, 76).

Reinoso claimed to have stumbled upon Dolce's Amorosi ragionamenti at a bookseller's store in Venice. This serendipitous story, offered in the letter of dedication (65), has a somewhat disingenuous ring to it, since Reinoso and Dolce without doubt moved in the same circles in Venice. It is also no coincidence that it was none other than Reinoso's printer Giolito who had produced Dolce's book. Dolce was himself embroiled in a rapid series of editorial and philological attempts at recuperating the whole of Tatius, and it thus may warrant a brief detour in appreciation of this history.

The first Latin translation of Leucippe and Cleitophon by Luigi Annibale della Croce, published in Lyon in 1544, was incomplete, containing only books $5^{-8}$. In his dedicatory epistle to the Spanish ambassador in Venice, Diego Hurtado de Mendoza (to whom the Lazarillo de Tormes has been occasionally attributed), della Croce deplores the fragmentary transmission of the text, now aptly published under the title Narrationis amatoriae fragmentum, and the anonymity of its author (who wrote, as della Croce says, under the persona of Cleitophon). Of the historical context, however, della Croce is fairly certain, and he correctly places the author in the Second Sophistic (fol. $\mathrm{A2}^{\mathrm{v}}$ $\mathrm{A}_{3}{ }^{\mathrm{r}}$ ). Tatius' full text was made available in Latin translation shortly thereafter, in 1551, to be followed by French (1572), English (1597), Spanish (1617), German (1644), and Dutch (1652) versions. By 1554, less than ten years after the first Latin edition, Achilles Tatius was firmly established as the original author.

While this rapid sequence of translations and editions was underway, the text continued to be transmitted in manuscript. The Austrian National Library, for example, where I conducted most of my research for this chapter, holds a collection of excerpts from the novel under the title De Leucippes et Clitophontis amoribus dating from 1490-1510 (Cod.Phil.gr. 329). It was bought by Ogier Ghislain de Busbecq (as noted on fol. 112 imperial emissary who travelled to Constantinople in $1554 / 55$. It was in the context of the diplomatic relations and expeditions to the Osman Empire that these manuscripts kept coming to Europe. The long-term transmission of the 
Greek novel and its conversion into the novela bizantina ${ }^{5}$ is at the same time intricately linked to contemporary power relations and depends on a vital Mediterranean network of communication and political negotiation.

Leucippe and Cleitophon was the only one of the five extant Greek novels to rely on first-person narration. In line with Achilles Tatius' original, Reinoso retains this narrative device, but shifts narration from Cleitophon ${ }^{6}$ to the "sin ventura" Isea, as 'the other woman,' the counterpart of the original Melite. Isea is a "narradora omnisciente en primera persona" (Cruz Casado 1994: 25) who is cognizant of events she did not take part in, a logically impossible narratological mode that undermines the autobiographical character that has been attributed to Isea's story (cf. Deffis de Calvo 138).

\section{Lament and Detachment}

Glenn Most has established a link between the choice of first-person narration in Greek prose and the framing of the narration as a kind of lament. Speaking with a view toward both fictional and factual accounts, he argued that "a constraint seems to have tended to limit the production of autobiographical discourses in Classical Greece and to confine them to laments about misfortune or self-defences under attack" (Most 126). According to Most, telling one's own story had to take the form of a lament; it could not be an account of individual triumphs and successes. This social, and, as a consequence, literary constraint was coupled with an ethical ideal of self-sufficiency. "Greek theologians, at least from Plato through the Epicureans and Stoics," Most writes, "define the divine as that which stands in need of nothing outside itself", thus it is "not surprising that self-sufficiency comes to be one of the characteristics most frequently attributed to the man of wisdom and virtue" (128).

Reinoso did not cater to the norms of ancient Greek society but rather to the predilections of an early modern reading public. His approach clearly hit a nerve; and despite his book seeing only one edition, the tone Reinoso introduced into the Castilian vernacular worked its way into other early modern texts. Lope de Vega's El peregrino en su patria, for instance, which got rid of the pastoral and chivalric elements, firmly established the novela bizantina as a

5 As elaborated by Menéndez Pelayo; Teijeiro Fuentes 2007; Torres.

6 Cleitophon is actually an intradiegetic narrator, prompted to tell his story by 'the author' at the beginning when the two meet in front of a painting of Europa and the bull, but this narrative bracket is not closed at the end. 
tale of destitution and displacement in the contemporary world. Where Isea describes herself as "sin él [i.e. Clareo], y sin marido, y sin honra, y sin ningún descanso" (Núñez de Reinoso 137), Lope frames the fate of his Peregrino - "[el] largo proceso de sus trabajos", as one of continuous demotion:

pues de cortesano vino a soldado, de soldado a cautivo, de cautivo a peregrino, de peregrino a preso, de preso a loco, de loco a pastor y de pastor a mísero lacayo de la misma casa que fue la causa original de su desventura $[\ldots]$.

LOPE DE VEGA $472-473$

Lope's third-person narration does abstain from complaint and matter-offactly lists the episodes of the hero's downward spiral, but this is neither an idealising nor a hopeful narrative. The desperate mood and the ethical goal of self-sufficiency are eventually lifted from the narrow and rare frame of firstperson narration and come to inform the genre or at least its most remarkable exponents in the early modern period (cf. Brusa).

Despite enriching the Hellenistic scheme with both chivalric and pastoral elements, Reinoso firmly denied having written a chivalric romance, denouncing the shallowness that supposedly plagued the genre: "[...] quien a las cosas de aquel libro diere nombre de las vanidades de que tratan los libros de caballerías, dirá en ello lo que yo en mi obra no quise decir [...]" (Núñez de Reinoso 197, n. 145). In the face of the overwhelming success of chivalric novels in the early modern period, this is nevertheless quite a common repudiation, shared for example in one of the era's most popular works, the Libro áureo de Marco Aurelio (1543) by Antonio de Guevara. Guevara expressed his concern about the many young men who spent, or rather wasted, their time immersing themselves in the adventures of Amadís, Primaleón, Lisuarte and all the others (Guevara, prólogo general). But this damning judgment does not do justice to how the libros de caballerías were actually read. They were taken as manuals that staged, in action, ideals of comportment for a (generally male) elite. The Amadis de Gaula and its sequels

became the manual of the finished caballero, the epopee of faithful lovers, the code of honour which moulded many generations. Even in its superficialities and frivolities, it remained throughout the sixteenth century the textbook of polite deportment, the oracle of elegant conversation, the repertory of good manners and of gallantry in forms of address.

BRODRICK 4 O (SEe alsO PLACE; CACHO BLECUA; RIEGER) 
Libros de caballerías were read for action, yet the chivalric parts of Clareo $y$ Florisea do not attribute agency to Isea; she is certainly not depicted in action.

Even though the doncella andante is an occasional figure in sixteenthcentury chivalric novels (González Rovira 180-181; Marín Pina), Isea's role in what is essentially Felesindos' story in the second part of the novel deviates from established patterns. Not only is she a widow rather than a virgin (which is due to her being the counterpart of Achilles Tatius' Melitte), she is also not fully present in her own story. We as readers are the audience for a series of knightly adventures, as is Isea. It is as if she is not even present in the diegetic world. None of the many characters they encounter takes issue with a fully armoured knight being accompanied by a young woman on foot. They wander through landscapes that were not unfamiliar to readers of the chivalric novels of the time, thus traversing an entirely literary landscape. And what is more, nobody engages with Isea; she has no dialogic exchange with the characters they encounter. She observes and sometimes comments in her narrator's voice, but never engages directly with the various people they encounter. Isea, who is present with Felesindos all the time, turns more and more into a heterodiegetic narrator, leaving no trace in the narrated world, but rather offering insight into the conscience of characters, such as the highly personal thoughts of the sister of the king of Cyprus, Estrellinda, whom they meet on their way and who passes a sleepless night (Núñez de Reinoso 155). When watching a courtly gathering where nobody interacts with her, Isea is overcome with emotion and starts crying, to which, again, not a single person reacts - contrary to a scene following suit in which the queen begins to cry and is immediately comforted by Felesindos (Núñez de Reinoso 168):

Yo, estando ansí mirando aquellas damas y caballeros, sin saber por qué causa, sentí en mí una nueva mudanza y soledad, de tal suerte que los ojos se me comenzaron a henchir de lágrimas [...].

NÚÑEZ DE REINOSO 166

Isea's role has been described as that of a reporter of Felesindos' adventures (Cruz Casado 1994: 34), but while she does indeed narrate the course of events in more detail than actually afforded by the device of first-person narration, her mental disposition is quite different. Isea acts like a reader, silently observing moving scenes and crying when hearing sad stories, not being concerned with or ashamed of her emotions - because nobody can see her, it seems. Only when they reach Alexandria again does Isea become a full-fledged character and assume agency in the diegesis. For a large part of the narrative, Isea thus 
prefigures the reader of her own story who will be a distant observer of her fate and who, hopefully, will take her case as a prompt for moral reflection.

The pastoral world, on the other hand, is interspersed throughout yet contained in the heterotopias of the several mythical islands that can only be reached by boat. Pastoral intermezzi were common in libros de caballerías: both the Amadis de Grecia (1530) and the first three parts of the Florisel de Niquea (1532-35) contain pastoral episodes, characterised by the presence of shepherds (pastores) and the backdrop of the locus amoenus, thus foregrounding the setting, whereas the action in the libros de caballerías is typically devoid of descriptions of the surroundings (Cravens 40). When Isea eventually takes up residence on the insula Pastoril, she does not subject herself to pastoral pursuits: she does not engage in the leisurely debates and songs on love and longing typically favoured by the shepherds. The two worlds - Isea's travels and the chivalric and pastoral adventures she witnesses - do not merge. Thus, while Reinoso does not present his readership with a clear-cut imitation of Achilles Tatius' novel, but rather integrates elements of two of the most popular contemporary prose genres, he sets Isea apart from these traditional fictional worlds and lets her lament underwrite the whole story as a kind of basso continuo, setting tone and theme for the emerging genre of the novela bizantina. ${ }^{7}$

Not just in the chivalric and pastoral settings, but even in Reinoso's explication of the purpose of his work, Isea is marginalised. Reinoso claims to have written the "historia de Florisea" (a telling slip of the pen)

para avisar a bien vivir, como lo hicieron graves autores que, inventando ficciones, mostraron a los hombres avisos para bien regirse, haciendo sus cuentos apacibles por inducir a los lectores a leer su escondida moralidad [...]. Y ansí ninguna cosa hay en toda aquella historia que no tenga algún ejemplo para bien vivir.

NÚÑEZ DE REINOSO 196, n. 145

And what are the examples we are supposed to note? Married couples should learn from Clareo and Florisea how important it is to be faithful and virtuous; from Felesindos, that men need to show strength in order to eventually reach peace of mind; and from Isea? "[...] cuán bien están los hombres en sus tierras, sin buscar a las ajenas" (Núñez de Reinoso 196, n. 145).

This maxim is of course the exact opposite of Isea's story. Her example is, at best, one ex negativo, her travails proving that one should not travel. This peculiar lesson alludes to the discourse of moral philosophy and more specifically

7 For this genre characteristic see Brusa/Traninger. 
to Seneca's Epistulae morales ad Lucilium. In letters 28 and 104 it is made amply clear that travel will never offer an escape from one's troubles: "Animum debes mutare, non caelum" ("You need a change of soul rather than a change of climate", ep. 28, 1). Evidently, the novel needs to be read in conjunction with the larger moral-philosophical literature on which it builds and which, in turn, underwrites its otherwise elliptical messaging. Isea's story is squarely placed in a cluster of ethical concerns that was highlighted and discussed in a broad range of literature, from the classical authors that were required reading in the Renaissance classroom, such as Seneca; to the moral tales in the mirrors of princes that were often of far eastern and Arab descent; and to the adages and accompanying essays made popular above all by Erasmus of Rotterdam. ${ }^{8}$

Isea's story is one of despair and displacement, which she claims to share with her readers, or rather reader, whom she imagines as "otra Isea" (another Isea) who experiences similar hardships and turns to her text to commiserate, but also to deliberate:

Si mis grandes tristezas, trabajos y desventuras por otra Isea fueren oídas, yo soy cierta que serán no menos lloradas que con razón sentidas; pero con todo, pienso que pues mis tristes lágrimas ablandaron y enternecieron las duras piedras, que ansí hará a los blandos y tiernos corazones, so pena que no siendo así, confesarán que son más duros que las duras peñas. Esta mi obra, que solamente para mí escribo, es toda triste, como yo lo soy; es toda de llanto y de grandes tristezas, porque ansí conforme con todas mis cosas y tenga el hábito que yo tengo. Cuenta fortunas ajenas porque mejor se vea cuán grandes fueron las mías, y aun al presente son; no lleva estilo, ni orden, porque yo no quiero loor ni me conviene ninguno.

NÚÑEZ DE REINOSO 67

This is telling, not showing. Still, the passage sets the tone for the whole narrative arc in which Isea does not tire of not only recounting her fate, but commenting on it in this desperate vein. It may have been this tearful sentiment that prompted several critics to suggest that the novel was geared towards a predominantly female readership (Teijeiro Fuentes 1991: 11; González Rovira 172). I would, however, insist that there is no historical evidence that points to such a specific and comparatively narrow audience. Rather, these statements

8 I will discuss these connections in detail in a forthcoming book on Patterns Which Connect: Towards a Global Literary History. 
belong to a long-standing pattern of discrediting the genre (Egger 110-112). The claim probably builds on the customary happy ending involving the reunion of the separated lovers and its interpretation as romantic (in the modern sense) wish fulfilment catering to specifically female desire rather than the reestablishment of order. Indeed, the story of Clareo and Florisea does end with their reunion, but this happens early on, before Isea embarks on her travels.

Isea does not tire of framing her story as an account of insurmountable hardship, but at the same time she demonstrates an autarkeia that is unheard of for a woman of her time. Isea's travels are undertaken out of her own volition, turning her from the unloved, ersatz Flor-isea into a tireless traveller surviving an Od-isea. That she tearfully, but voluntarily takes leave of her friends and family to roam the world; that she joins a knight errant for part of the way, yet without acting like the damsel in distress, but rather walking alongside him; that she eventually sets off for Europe in search of the place that would allow for a self-sufficient existence - that this kind of agency is attributed to a woman highlights all the more that Isea's story is very much a meditation on human judgement in the face of adversity.

\section{$5 \quad$ Casuistry and the Prose Novel: A Shared Genealogy}

Casus conscientiae, cases of conscience, required a specific type of judgement: "The ultimate act of 'conscience' was a judgement in which the universal and the particular were known together (con-scire)" (Jonsen/Toulmin 153). And not least, this act of judgment needed to result in action, as stressed by Thomas Aquinas, which is why casuistry's methodological base was the syllogismus practicus, the practical syllogism that supplanted the conclusion by action (Jonsen/Toulmin 129; Summa theologica Ia, q. 79, a. 13; Kittsteiner 193-203). From its earliest beginnings in the penitential literature of the Middle Ages, casuistry

[...] emphasized acts and decisions as central elements in the moral life. It defined the basic structure of any moral situation: an individual, characterized in a certain way, performs an act of a certain kind, with a specific intention, and in a particular state of mind. It stressed discrimination between acts and their evaluation in the light of the stated circumstances.

JONSEN/TOULMIN 100 
Students of medieval and early modern Christian casuistry have noted that the casuists resorted to ancient rhetoric in order to tame the proliferation of circumstances (cf. Maryks). Rhetoric, of course, had long reduced potentially infinite circumstances to a topical grid, one that resonates through time and is still drilled into the heads of every journalism student today: quis, quid, ubi, quibus auxiliis, cur, quomodo, quando - who, what, where, by which means, why, how, when (Jonsen/Toulmin 132). D.W. Robertson has argued that, in addition, casuistical thinking is built specifically on the rhetorical distinction between thesis and hypothesis, the thesis being a general argument, the hypothesis taking into consideration the individual circumstances of a case (Robertson). Cicero discussed the distinction as an ancient one that could be traced back to Hermagoras (Cic. De inv. I, 6, 8; Bonner 5-11). Thesis and hypothesis were framed as resorting to philosophy and rhetoric, respectively, ${ }^{9}$ a view supported and confirmed by Boethius, who ensured their transmission to the Middle Ages (Leff 10). But in practice thesis and hypothesis were closely intertwined, and discussed as such, above all by Quintilian (Inst. orat. III, 5 , $5^{-10}$ ): while rhetoric was typically concerned with the specificity of individual cases, those could easily be stripped away to make a more general point and add weight to the argument.

Against this background, a shared genealogy of the novela bizantina and Christian casuistry emerges, and at its root is, surprisingly, the Second Sophistic of the Roman Empire. Mikhail Bakhtin pointed out that the Greek novel did feed on the rhetorical casuistry of the Second Sophistic (Bakhtin 12). ${ }^{10}$ The hypothesis forms the basis for the Second Sophistic practice of declamation, which was all about exploring individual cases under an abundance of circumstances bordering on the absurd. Of particular relevance are the so-called controversiae, fictional pleadings in imaginary court cases. The intriguing aspect of these controversiae was that not only were the cases, the 'lawyer' or 'counsel', the parties of conflict and the persons involved as well as the circumstances fictional, but also the laws which provided the framework for the pseudolegal argument. Declamation thus formed an artificial cosmos of reference, independent of contemporary judicial praxis (Bonner 51-70; Russell 87-105; Bloomer).

The extant argumenta for these controversiae summarise complex and improbable cases, which appear to be nothing more than extravagant entertainment. Yet recent research has found that these fantastic themes and

$9 \quad$ See Clarke; Throm.

10 For a critical discussion see Selden; for narratological implications, Traninger. 
constellations did in fact serve a conservative purpose: that of immersing students of rhetoric in the set of norms and values of a Roman citizen, of a pater familias and slave holder by contemplating these very values in outrageous and highly contrived situations (Bloomer 1997; Kaster; Gunderson 29-33). The techniques of declamatory rhetoric informed the prose novel, from characters' speeches to the fleshing out of complex situations in persuasive detail (Webb 535-538).

While medieval casuistry was the confessors' business, a sea change happened in the early modern period when cases of conscience were increasingly handed from trained specialists to the individual. Now confessors were

[...] to teach ordinary people how to examine their own moral lives and how to communicate about them with another person - namely, their confessor or spiritual director. [...] The common people could now be shown the relative importance of intentions, dispositions, consequences, and circumstances to the moral evaluation of their acts.

JONSEN/TOULMIN 142

This is not, as has often been claimed, a phenomenon brought about by the Reformation. Rather, an interiorisation of conscience took place across denominations in the early modern period, complementing as well as changing penitentiary practice.

As casuistry is handed over from priests to believers, this is accompanied by two shifts: first, case collections in the summae confessorum were complemented by fictional cases unfolding in literary texts. Second and in conjunction with this, we observe a shift from the oral-aural event of confession to the oral-aural event of sociable reading. The concept of interiorisation would seem to suggest that solitary immersion in a literary text and individual reflection would replace the dialogic interaction of confession, but all we know about reading in the early modern period points to a vastly different setting. With narrative texts staging individual action and moral dilemmas in scenarios of exuberant circumstance - think of Isea's fortunas ajenas - the judgment is handed to the reader or readers who were, more often than not, forming reading communities. It was these reading communities on which the early periodical press could later capitalize, as for example when Donneau de Visé invited the readers of the Mercure galant to weigh in on the moral dilemma underwriting Mme. La Fayette's La Princesse de Clèves (1678). He received so many responses that he could fill the journal's issues for an entire year (Dejean 6o-61). Reinoso himself does not offer much in terms of dilemmatic 
reasoning, but rather invites compassion as much as judgment, and in so doing delegates the task of moral reflection to his readers.

But why would casual readers feel attracted by such a dire view of the human condition? Clareo y Florisea was written by a converso in exile, a muchdiscussed fact that inspired biographical and allegorical readings of the novel (Bataillon; Rose 1971; Cruz Casado 1988; Teijeiro Fuentes 1991; Marguet). But the topic of exile and the fundamental loss of certainties was not exclusive to the early modern converso community - even if they, of course, suffered to an extent unimaginable to other groups. One of the reasons why the refashioning of the Greek novel was so successful was because it addressed or made accessible in literary format the experience of uprootedness, deprivation, displacement, destitution and loss of status and prerogatives. Pedro Mexía's contemporary and hugely popular Silva de varia lección (1540) with its extensive chapters on destierro (II, 20 \& 21), compiling a broad range of examples from literature and history, amply documents a profound interest in questions of displacement, loss of rank, and destitution. This was in particular an experience not of the lower classes, who found a literary figuration in the picaro. Indeed, the novela picaresca, invented at around the same time as the novela bizantina, tells the complementary story: that of a petty criminal or low life and their ascent to a moderate livelihood.

When Isea refers to herself as "peregrina, perdida, acosada y estranjera" (Núñez de Reinoso 141), she certainly does not allude to Christian peregrinatio in the sense of a pilgrimage. Of course, peregrinatio and the picturing of human life as a pilgrimage was an immensely productive metaphor in Golden Age literature (cf. Hahn; Nitsch; Ehrlicher). A prominent line of interpretation is that of a Counter-Reformation piety that found its place in the transformed Greek novel, featuring man as a "peregrino, romero por tierra" (Teijeiro Fuentes 1991: 9), turning the novela bizantina into a vehicle of Catholic reform (cf. Vilanova). But not least Reinoso's many allusions to Ovid's Tristia (Gonzalez Rovira 172) firmly establish his peregrina as a foreigner rather than a pilgrim, and they point to the deplorable status of an exile rather than the pursuits of a godly wanderer (Rose 1971: 126).

The peregrina/peregrino of the early modern Spanish novela bizantina is a noble, or at least high-standing, character who has to get by having lost their signs of status and identity. This narrative of survival is a trope for an all-toocommon experience for early modern courtiers: with every succession (and at times they came at short intervals), the scrambling for positions at court began anew. Favourites of deceased kings could never count on the continuation of their luck, quite to the contrary. Chances were that there would be droves of rivals who had long awaited the opportunity to move past them. What would 
have been a handsome income in the form of a pension or an office could disappear overnight. Or someone could be banned from the corte, Madrid, or Castile as a whole, as had happened to Lope de Vega for two and eight years respectively, or struggle for decades to secure patronage in the first place (Wright). And this kind of existential insecurity was not limited to the secular courts: Mario Biagioli has shown in his marvellous book on Galileo as a courtier how the Papal Court in Rome was subject to the same, if not even more drastic mechanisms of patronage and shifting fortunes (Biagioli esp. 316-323).

The refashioned Greek novel plays to these existential questions. As a genre, it is darker and more serious than all the other prose genres that emerge at the time. Criticized by later generations of scholars as sappy, the de rigueur happy ending and the reunion of the separated lovers seem not to be at the core of the narrative impact. Rather, by adopting and adapting the exuberant Greek scenarios, the novela bizantina offers a mise-en-scène of overwhelming circumstances and a cast of characters whose desperate attempts at navigating them puts the reader in charge of contemplating cases of conscience - those incurred by the characters, but just as much their own.

\section{Works Cited}

Bakhtin, Mikhail. "The Bildungsroman and Its Significance in the History of Realism (Toward a Historical Typology of the Novel)." Speech Genres and Other Late Essays. Austin, TX: University of Texas Press, 1987: 10-59.

Bataillon, Marcel. "Alonso Núñez de Reinoso y los marranos portugueses en Italia." Varia lección de clásicos españoles. Madrid: Gredos, 1964: 55-80.

Biagioli, Mario. Galileo Courtier. The Practice of Science in the Culture of Absolutism. Chicago, IL/London: The University of Chicago Press, 1993.

Bloomer, W. Martin. "Schooling in persona: Imagination and Subordination in Roman Education." Classical Antiquity 16.11 (1997): 57-78.

Bloomer, W. Martin. "Roman Declamation: The Elder Seneca and Quintilian." $A$ Companion to Roman Rhetoric. Eds. William J. Dominik and Jon Hall. Malden, MA: Blackwell, 2007: 296-306.

Bonner, S.F. Roman Declamation in the Late Republic and Early Empire. Liverpool: Liverpool University Press, 1969.

Brodrick, James sJ. Saint Ignatius Loyola: The Pilgrim Years. London: Burns \& Oates, 1956.

Brusa, Paolo. Peregrinatio als Novation. Heliodors Muster in Lope de Vegas El peregrino en su patria (1604) und seine Folgen für die novela helenizante. Ph.D. dissertation, Freie Universität Berlin, 2021 (forthcoming). 
Brusa, Paolo/Traninger, Anita. Lesekontext und Affektregime: Probleme der Gattungsmischung in der Erzählprosa des Siglo de Oro. FOR 2305 Working paper, Freie Universität Berlin, 2018 (10.17169/refubium-508).

Cacho Blecua, Juan Manuel. Amadís: Heroísmo mítico cortesano. Madrid: Cupsa, 1979.

Clarke, M.L. "The Thesis in the Roman Rhetorical Schools of the Republic." The Classical Quarterly 1.3-4 (1951): 159-166.

Cravens, Sydney Paul. "The Insula Deleitosa Tale in Alonso Núñez de Reinoso's Clareoy Florisea: A Tribute to Feliciano de Silva." Hispanófila 64 (1978): 1-6.

Cruz Casado, Antonio. "Exilio y peregrinación en el Clareo y Florisea (1552), de Alonso Núñez de Reinoso." 1616, Anuario de la Sociedad Española de Literatura General y Comparada IV-VII (1988): 29-35.

Cruz Casado, Antonio. 'La inacabada 'Historia del Caballero Felesindos', de Alonso Nuñez de Reinoso, en Clareo y Folorisea (1552)." Revista de literatura 56.111 (1994): 23-38.

Deffis de Calvo, Emilia I. "El cronotopo de la novela española de peregrinación: Alonso Núñez de Reinoso y Lope de Vega." Criticón $5^{6}$ (1992): 135-146.

DeJean, Joan E. Ancients Against Moderns: Culture Wars and the Making of a Fin de Siècle. Chicago, IL/London: University of Chicago Press, 1997.

Egger, Brigitte Maria. "The Role of Women in the Greek Novel: Woman as Heroine and Reader." Oxford Readings in the Greek Novel. Ed. Simon Swain. Oxford: Oxford University Press, 1999: 108-136.

Ehrlicher, Hanno. "Poetas peregrinos: autoconfiguraciones autoriales en las novelas de aventuras de Lope de Vega y Miguel de Cervantes." eHumanista/Cervantes 1 (2012): 211-225.

García Gual, Carlos. Historia de amantes peregrinos. Las primeras novelas. Discurso leído el día 17 de febrero de 2019. Madrid: Real Academia Española, 2019.

Goldhill, Simon. “Genre.” The Cambridge Companion to the Greek and Roman Novel. Ed. Tim Whitmarsh. Cambridge: Cambridge University Press, 2008: 185-200.

González Rovira, Javier. La novela bizantina de la Edad de oro. Madrid: Gredos, 1996.

Grunebaum-Ballin, Paul.Joseph Naci duc de Naxos. Paris: Mouton, 1968.

Guevara, Antonio de. Marco Aurelio, con el Relox de principes. Sevilla: Cromberger, 1543. Gunderson, Erik. Declamation, Paternity, and Roman Identity. Authority and the Rhetorical Self. Cambridge University Press, 2003.

Hahn, Jürgen. The Origins of the Baroque Concept of Peregrinatio. Chapel Hill, NC: University of North Carolina Press, 1973.

Hunger, Herbert. Katalog der griechischen Handschriften der Österreichischen Nationalbibliothek 1: Codices historici, codices philosophici et philologici. Vienna: Prachner/Hollinek, 1961.

Leff, Michael C. “The Logician's Rhetoric. Boethius' De Differentiis Topicis, Book IV." Medieval Eloquence: Studies in the Theory and Practice of Medieval Rhetoric. Ed. 
James J. Murphy. Berkeley/Los Angeles/London: University of California Press, 1978: 3-24.

Jolles, André. Einfache Formen. Legende/Sage/Mythe/Rätsel/Spruch/Kasus/Memorabile/ Märchen/Witz. Halle/Saale: Niemeyer, 1956.

Jonsen, Albert R./Toulmin, Stephen. The Abuse of Casuistry: A History of Moral Reasoning. Berkeley/Los Angeles/London: University of California Press, 1988.

Kaster, Robert A. "Controlling Reason: Declamation in Rhetorical Education at Rome." Education in Greek and Roman Antiquity. Ed. Yun Lee Too. Leiden/Boston: Brill, 2001: $317-37$.

Kittsteiner, Heinz D. Die Entstehung des modernen Gewissens. Frankfurt: Insel, 1992.

Marguet, Christine. "De Leucipa y Clitofonte de Aquiles Tacio a la Historia de los amores de Clareo y Florisea de Alonso Núñez de Reinoso: un caso de reescritura novelesca entre traducción y creación." Criticón 76 (1999): 9-22.

Marín Pina, Ma Carmen. "La doncella andante en los libros de caballerías españoles: La libertad imaginada (II)." eHumanista 16 (2010): 221-239.

Maryks, Robert Alexander. Saint Cicero and the Jesuits. The Influence of the Liberal Arts on the Adoption of Moral Probabilism. Aldershot: Ashgate, 2008.

Menéndez Pelayo, Marcelino. Orígenes de la novela. Madrid: Gredos, 2008.

Mexía, Pedro. Silva de varia lección. Ed. Antonio Castro, 2 vols. Madrid: Cátedra, 1989.

Michaud-Quantin, Pierre. Sommes de casuistique et manuels de confession au moyen âge (XII-XIV siècles). Louvain/Lille/Montreal: Nauwelaerts, 1962.

Morgan, J.R. "Make-Believe and Make Believe: The Fictionality of the Greek Novels." Lies and Fiction in the Ancient World. Ed. Christopher Gill, Austin, TX: University of Texas Press, 1993: 175-229.

Most, Glenn W. “The Stranger's Stratagem: Self-Disclosure and Self-Sufficiency in Greek Culture." The Journal of Hellenic Studies 109 (1989): 114-133.

Nitsch, Wolfram. "Das Subjekt als peregrino. Selbstbehauptung und Heteronomie in Góngoras Lyrik." Welterfahrung - Selbsterfahrung. Konstitution und Verhandlung von Subjektivität in der spanischen Literatur der frühen Neuzeit. Eds. Wolfgang Matzat and Bernhard Teuber. Tübingen: Niemeyer, 2000: 363-377.

Núñez de Reinoso, Alonso. Historia de los Amores de Clareo y Florisea, y de los Trabajos de Ysea: con otras obras en verso, parte al estilo Español, y parte al Italiano. Agora nuevamente sacada a luz. Venice: Gabriel Giolito de Ferrari \& brothers, $155^{2}$.

Núñez de Reinoso, Alonso. Los amores de clareo y Florisea y los trabajos de la sinventura Isea. Ed. Miguel Angel Teijeiro Fuentes. Cáceres: Universidad de Extremadura, 1991. Place, Edwin B. "El Amadís de Montalvo como manual de cortesanía en Francia." Revista de Filología Española 38 (1954): 151-169.

Rieger, Dietmar. “Amadis und andere.Zu den literarischen Leitfiguren 'ritterlicher' Eliten des 16. Jahrhunderts." Die Inszenierung der heroischen Monarchie. Frühneuzeitliches 
Königtum zwischen ritterlichem Erbe und militärischer Herausforderung. Ed. Martin Wrede, Munich: Oldenbourg, 2014: 40-56.

Robertson, D.W. "A Note on the Classical Origin of 'Circumstances' in the Medieval Confessional." Studies in Philology 43.1 (1946): 6-14.

Rose, Constance Hubbard. Alonso Núñez de Reinoso: The Lament of a Sixteenth-Century Exile. Rutherford/Madison/Teaneck: Fairleigh Dickinson University Press, 1971.

Rose, Constance Hubbard. "New Information on the Life of Joseph Nasi Duke of Naxos: The Venetian Phase." The Jewish Quarterly Review 6o.4 (1970): 330-344.

Rose, Constance Hubbard. “Alonso Núñez de Reinoso's Contribution to the Creation of the Novel." Creation and Re-Creation: Experiments in Literary Form in Early Modern Spain: Studies in Honor of Stephen Gilman. Eds. Nora Weinerth, Ronald E. Surtz and Stephen Gilman. Newark, DE: Juan de la Cuesta, 1983: 89-103.

Russell, D.A. Greek Declamation. Cambridge: Cambridge University Press, 1983.

Saporta Beja, Nicolas. Deux grandes figures juives de la Renaissance: Doña Gracia Mendesia Nasi, Don Joseph Nasi, duc de Naxos. Paris: Éditions Vidas Largas, 1985.

Selden, Daniel L. "The Anti-Sophistic Novel." The Oxford Handbook of the Second Sophistic. Eds. Daniel S. Richter and William A. Johnson. Oxford: Oxford University Press, 2017: 421-446.

Seneca. Ad Lucilium epistulae morales. Trans. Richard M. Gummere, 3 vols. Loeb Classical Library. Cambridge, MA: Harvard University Press (1917, 1920, 1925).

[Tatius, Achilles]. Narrationis amatoriae fragmentum è graeco in latinum conversum, L. Annibale Cruceio interprete. Lyon: Sebastian Gryphius, 1544.

[Tatius, Achilles]. Amorosi ragionamenti. Ne i quali si racconta un compassionevole amore di due amanti, tradotti per M. Lodovico Dolce, dai fragmenti d'uno antico scrittor greco: \& di nuovo corretti \& ristampati. Venice: Gabriel Giolito de Ferrari, 1547.

Tatius, Achilles. Leucippe and Clitophon. Trans. with notes by Tim Whitmarsh. Oxford: Oxford University Press, 2001.

Teijeiro Fuentes, Miguel Ángel. “Clareo y Florisea o la historia de una mentira." Anuario de Estudios Filológicos 7 (1984): 353-359.

Teijeiro Fuentes, Miguel Ángel. “Introducción.” Alonso Núñez de Reinoso: Los amores de Clareo y Florisea y los trabajos de la sin ventura Isea. Ed. Miguel Ángel Teijeiro Fuentes, Cáceres: Universidad de Extremadura, 1991: 7-64.

Teijeiro Fuentes, Miguel Ángel. "Marcelino Menéndez Pelayo en los orígenes de los estudios bizantinos." Orígenes de la novela. Estudios. Eds. Raquel Gutiérrez Sebastian and Borja Rodríguez Gutiérrez. Santander: Sociedad Menéndez Pelayo, Universidad de Cantabria, 2007: 261-277.

Thomas Aquinas, Summa theologiae, Corpus Thomisticum (corpusthomisticum.org/ iopera.html, accessed 21 December, 2020).

Throm, Hermann. Die Thesis. Ein Beitrag zu ihrer Entstehung und Geschichte. Paderborn: Schöningh, 1932. 
Torres, José B. “ ¿Novela bizantina o novela helenizante? A propósito de un término consagrado." Ars bene docendi: homenaje al profesor Kurt Spang. Eds. Ignacio Arellano Ayuso, Víctor García Ruiz and Carmen Saralegui Platero. Pamplona: EuNSA, 2009: 567-574.

Traninger, Anita. "Erzähler und persona. Rhetorik und Narratologie zwischen Mündlichkeit und Schriftlichkeit." Wege moderner Rhetorikforschung. Klassische Fundamente und interdisziplinäre Entwicklung. Eds. Gregor Kalivoda and Gert Ueding, Berlin/Boston: de Gruyter, 2013: 185-210.

Vega Carpio, Lope de. El peregrino en su patria. Ed. Juan Bautista Avalle-Arce. Madrid: Castalia, 1973.

Vilanova, Antonio. “El peregrino andante en el Persíles de Cervantes." Boletín de la Real Academia de Buenas Letras de Barcelona 22 (1949): 97-159.

Webb, Ruth. "Rhetoric and the Novel: Sex, Lies and Sophistic." A Companion to Greek Rhetoric. Ed. Ian Worthington. Williston: Blackwell, 2006: 526-541.

Wright, Elizabeth R. Pilgrimage to Patronage: Lope de Vega and the Court of Philip III, 1598-1621. Lewisburg: Bucknell University Press, 2001.

Zimic, Stanislav. "Alonso Núñez de Reinoso: traductor de 'Leucipe y Clitofonte." Symposium 21.2 (1967): 166-175. 


\title{
Comic Casuistry and Common Sense: Sancho Panza's Governorship
}

\author{
Michael Scham
}

\begin{abstract}
Key background to Sancho Panza's governership of Barataria (Don Quijote II. 42-53) includes the specula principum tradition, treatises on statecraft (Furió Ceriol, Ribadeneira, Castillo de Bobadilla) and other casuistic tratados. Demonstrating the importance of circumstance and narrative economy, of wisdom derived from experience and of properly knowing oneself (nosce te ipsum), Sancho embodies many traits of the ideal ruler, even as he improvises in his own inimical manner.
\end{abstract}

\section{Keywords}

Sancho Panza - Barataria - statecraft - casuistry - novelistic character

Although casuistry in Cervantes has been discussed primarily in relation to his theatrical works, ${ }^{1}$ recent studies of legal and political discourse in Don Quijote $^{2}$ bring casuistry to the fore in Cervantes' engagement with contemporary ideas on statecraft and jurisprudence. While examining the interrelated development of legal and casuistical procedure in early modern Spain, Roberto González Echevarría notes how Don Quijote's questioning of the galeotes (DQ I.22) dramatizes a new aesthetic concerned with circumstances: "This casuistry makes way for the concreteness of the new literature, focused on individuals, specific events, objects, and settings, spurning not just received literary but also philosophical traditions" (33). Contending that this "new literature" is inimical to allegorical readings, to abstractions, González Echevarría

1 Hilaire Kallendorf suggests that Cervantes favored the Jesuit educational program, as evidenced in the festive scene of Berganza playing with the students in El coloquio de los perros (Kallendorf 25-6). Luis Gómez Canseco demonstrates the importance of probabilism in $L a$ gran sultana, as well as how casuistry is present in Cervantes' theater generally, informing plot structures from exposition to denouement, directing our attention from norm to particular circumstance and the dilemma of decision-making (Gómez Canseco).

2 See Byrne, especially Ch. 3; Cascardi Ch. 3 \& 6. 
is consonant with Borges, who urges us to read Don Quijote not as allegory (or parody, for that matter), but as "la venerable y satisfactoria presentación de una gran persona, pormenorizada a través de doscientos trances, para que lo conozcamos mejor" (2012: 216). ${ }^{3}$ One of the things we learn about our gran persona, according to Borges, is that he is envious of his squire when Sancho Panza is at long last given his governorship. The following pages will focus on what is revealed not about the knight, but rather about Sancho Panza, as he passes through the crucible of the governorship of Barataria.

The present study reveals multiple aspects of casuistry in Don Quijote. One is the general "method of mind" which Henry Sullivan saw as pervasive in the culture of Cervantes' Spain, and which is evidenced in the mode of argumentation in many of the scenes we shall consider. There are also numerous instances in which the confessional casuistry of "examination of conscience" and contemplation of sins is evoked. As we shall see, the most pronounced vein of casuistry in the Barataria episodes is that involving the conscience of the ruler, that is, the casuistry of statecraft.

It is widely acknowledged that the specula principum genre is behind much of the episode, from don Quiote's consejos to the qualities Sancho displays in his actions and judgments. Among the major background texts are Jerónimo Castillo de Bobadilla's Política de corregidores (1597), Pedro de Ribadeneira's Tratado de la religion y las virtudes (1595), and possibly Fadrique Furió Ceriol's El consejo y consejeros del Príncipe (1559). Issues treated in such works, and which are taken up in the Barataria episode, include the bearing and dress of the ruler, his pastimes, promulgation of laws and acknowledgment of local customs, the comparative virtues of severity vs. leniency, and choosing of advisers. ${ }^{4}$ Horacio Chiong Rivero maintains that the Barataria episode offers little in terms of precept that represents any innovation to the long tradition of specula principum literature; but the way Sancho engages with this tradition and, not least, his manner of ultimately taking leave of it, is unprecedented: "la modernidad cervantina radica en la novelización de toda una gama de avisos pragmáticos que distan del objetivo y del tono moralizantes de los tratados políticos" (136). In accordance with Chiong Rivero's emphasis on the particular subjectivity Sancho brings to bear on the conventions of specula principum, I will underline how - with the episode's focus on Sancho's

3 For additional comments on casuistry in Cervantes, see David Mañero Lozano's essay in this volume.

4 A good summary of the scholarship on the sources is offered by Horacio Chiong Rivero, who argues also for the importance of Guevara's Relox de príncipes (1529) as a source. See also Bleznick, Cascardi, Percas de Ponseti, and Fernández Santamaría. 
conscience - the "novelization" of the subject matter owes much to innovations in casuistical thought.

\section{The Tension between Precept and Circumstance: Sancho's refranes}

As the essays in this volume variously discuss, a fundamental quandary addressed by the casuists was the potential inapplicability of existing precept (laws, commandments, prior learned opinion) to particular situations. The confidence of the exemplary tradition in setting forth valid models gives way to a questioning of the models, be it examples of illustrious actions from the past or laws handed down from distant times and places. Even church authorities were re-examined, to the extent that substantive conflicting opinions could be found. ${ }^{5}$ Thus came about the exquisite attention to circumstance, to complex particularities, that is a hallmark of casuistical thought. The novelistic quality of Don Quijote owes much to the nuanced epistemology of casuistry; and Sancho's use of proverbs provides an illustration in miniature.

Along with references to diverse aspects of bodily and animal experience, as well as customary malapropisms, the refranes of Sancho represent linguistic usage that is deeply connected with the identity and lived reality of the speaking subject. While the proverbs may convey a sort of practical, empiricallybased wisdom of the popular classes, Sancho frequently fails to use them coherently - as an exasperated Don Quijote repeatedly points out: "Yo te aseguro que estos refranes te han de llevar un día a la horca; por ellos te han de quitar el gobierno tus vasallos, o ha de haber entre ellos comunidades. Dime, ¿dónde los hallas, ignorante, o cómo los aplicas, mentecato, que para deciryo uno y aplicarlo bien sudo y trabajo como si cavase?" (II. 43 italics added). Even as he sometimes marvels at Sancho's ability to recite multiple proverbs with the slightest pretext, Don Quijote rightly points out that it is quite another thing to apply one judiciously. Despite the proverb's claim to reveal general truths about the ways of the world, Don Quijote observes that there is still some contingency, one must correctly consider the present circumstances, and judge whether they are sufficiently analogous to the proverb. And, as he well expresses, it is hard work to do so. Don Quijote's digging analogy calls to mind the etymology of "exemplum," which, as Lyons has discussed, derives from a "clearing in the woods," and the process of "selecting, framing, and regulating

5 For the background of such "probabilistic" thinking, see Maryks (2016). Sullivan noted how casuistry could provide alternative, ameliorating perspectives for "ordinary people disconcerted by the sternness of religious commandments" (44). 
(that is, subordinating to a rule) some entity or event" (Lyons 3-4). Chosen well, an example may illuminate a present situation, or even serve as guide; indiscriminate use produces mere accumulation, rather than something that is illustrative or persuasive (Lyons 10). Sancho's proverbs frequently fall into this second category, as he himself admits: "sé más refranes que un libro, y viénenseme tantos juntos a la boca cuando hablo, que riñen por salir, unos con otros; pero la lengua va arrojando los primeros que encuentra, aunque no vengan a pelo" (II. 43). As we will see, both the cases in which Sancho errs and those in which he seems to hit the mark provide insight into the casuistical quandary of appealing to the appropriate authorities and precepts when making sense of, as Lyons put it with regard to example, "some entity or event."

\section{Sancho Gobernador: Laws and Adjudication}

Pedro de Ribadeneira's discussion of laws and circumstances, and the importance of good advisers (Tratado de la religion y las virtudes, especially Bk. II. 32-33), is relevant to Sancho's governorship. The primary adviser, of course, is Don Quijote, whose letter to Sancho finds its sources in the specula principum tradition. ${ }^{6}$ And part of his counsel has to do with setting laws:

No hagas muchas pragmáticas; y si las hicieres, procura que sean buenas, y, sobre todo, que se guarden y cumplan; que las pragmáticas que no se guardan, lo mismo es que si no lo fuesen; antes dan a entender que el príncipe que tuvo discreción y autoridad para hacerlas, no tuvo valor para hacer que guardasen. (II. 51)

Ribadeneira had expressed the same idea in the following terms:

[...] el Principe pierde reputacion quando sus leyes no son obedecidas. Y por esso conviene que las leyes sean pocas, y muy miradas [...] Y con razon se llama el Principe ley biva, no solo porque tiene potestad para hazer la ley é interpretarla, y dispensar en ella, sino tambien porque la ley por si es muerta, si el como anima de la ley con su exemplo no le da vida. (II. 32 )

6 See, for example, Percas de Ponseti, who argues that Cervantes parodies some of the commonplaces promoted by Valdés and Guevara (voiced by don Quijote), while remaining in step with contemporary moralists such as Bobadilla and Mariana. 
Susan Byrne has discussed the backdrop of legal chaos and cacophony in Spain during this time as attempts were made to consolidate the various codes and integrate them with local customs to ensure their clear promulgation. Felipe II's Recopilación (1567) refers to this dilemma: "Porque somos informados, que muchas leyes y premáticas que hemos hecho para el buen govierno destos Reynos, no se han guardado; ni guardan" (cited in Byrne 101). Sancho's "Constituciones" echo much contemporary legislation, including the "Recopilación," for example in his prohibition of "cantares lascivos y descompuestos, ni de noche ni de día" (II. 51). ${ }^{7}$

If Sancho's process of selecting and implementing laws, with Don Quijote's guidance, represents a sort of tutiorism, mandating strict punishments for any transgression, other aspects of his governing are in the vein of probabilism, as he displays interest in the nuance and circumstances of the cases before him. In this he is consistent with Ribadeneira, who, given his hard line on the viability of laws ("la ley siempre es la misma é invariable", II. 14) and opposition to freedom of conscience, is sometimes surprisingly sensitive to the complexity of prudent rule. He emphasizes, for example, the importance of listening to the grievances of his vassals; ; and Ribadeneira's art of princely prudence, which cannot be gained by blind adherence to rules, produces the following probabilistic discourse: "por ser tantos los particulares, y tantas y tan varias las circunstancias que el verdadero prudente deve considerar en sus acciones, para acertar, que no se pueden con ningunas reglas comprender" (II. 33).

Castillo de Bobadilla's Política de corregidores (1597) also provides some of the blueprint for Sancho's governorship. As Benjamín González Alonso notes in the preliminary study to his edition, Castillo de Bobadilla's mode of thought owes much to scholasticism and casuistry: the truth is there to be found in the existing authorities, but the intellectual endeavor consists of interpreting these existing truths, illustrating them in concrete cases (Castillo de Bobadilla 23). ${ }^{9}$ The Second Book of Politica de corregidores contains a striking number of parallels with Sancho's administration of Barataria. Sancho coincides with

7 See Jean-Marc Pelorson's commentary to the chapter, note 3/39, in https://cvc.cervantes.es/ literatura/clasicos/quijote/edicion/parte2/cap51/cap51_o3.htm.

8 "Porque cuando no se oyen las justas quexas de los vassallos contra los Governadores, de mas de cargo de la conciencia, los mismos Governadores se hazen mas absolutos, y los vassallos viendo que no son desgraviados no oydos, entran en desesperacion" (Ribadeneira II. 32).

9 Among others, Percas de Ponseti has noted the relevance of Castillo de Bobabilla to the Barataria episode. While noting Castillo de Bobadilla's discussion of cases in which a corregidor may contravene laws, Byrne points out the casuistical slippery slope that can result: "he notes six specific reasons that allow a corregidor to go against the law with impunity in a broad sense (II.10.69-76, 1:386-7). Additionally, after each general rule duly noted, this magistrate lists the multiple doubts, occasions, amplifications, and limitations that contradict its stipulations" (48). 
Castillo de Bobadilla in his critique of excessive leisure (both illustrate their argument incorporating the emblem of the industrious bee), the importance of curtailing vagrancy and promoting productive labor, of gambling reform, and in his recommendation that the governor involve himself in the disputes and conflicts of his subjects ("conviene interponerse en questiones y renzillas", Castillo de Bobadilla II. 45). Sancho's critique of the excesses of the Duke and Duchess's dedication to the hunt resonates with Castillo de Bobadilla's censure of idle nobility who do not set forth positive examples for the lower estates; and Sancho performs the sort of hunt advocated in Política de corregidores, the "caça nocturna": "Conviene pues, que el Corregidor ronde, y sus Oficiales no duerman y que todos velen, e esten en centinela" (II. 8).

The first renzilla encountered by Sancho and his ministers as they perform the rounds are two men who have emerged from a gambling den, and whose dispute has escalated to a physical altercation. They are commanded to explain themselves so that Sancho may consider the case. The response of the first man, an onlooker who had helped the other during his winning run at cards, abounds in casuistical discourse: he heeds dictates of narrative economy ("le diré con toda brevedad") - a point to which we will return -, refers to more than one "suerte dudosa" (or dispute), during which he advocated for the other man, and refers twice to conscience: "contra todo aquello que me dictaba la conciencia"; "qué poca vergüenza y qué poca conciencia!" (II. 49). After listening to the counterclaim, Sancho touches upon the casuistry of gambling gains ("vos, ganancioso, bueno, o malo, o indiferente"), summarizes the circumstances of each claimant, and provides a nuanced if firm judgment, tailoring a punishment to each one of them and simultaneously addressing social needs:

[...] dad luego a este vuestro acuchillado cien reales, y más habéis de desembolsar treinta para los pobres de la cárcel; y vos, que no tenéis oficio ni beneficio, y andáis en nones en esta ínsula, tomad luego esos cien reales y mañana en todo el día salid desta ínsula desterrado por diez años. (II. 49)

When he then declares his intention to get rid of the gambling dens, he learns a lesson about political power as well as gradations of vice. As the escribano observes, the power of the social elite stands in the way: "Esta, a lo menos (...) no la podrá vuesa merced quitar, porque la tiene un gran personaje” (II. 49). But the proposed compromise also involves accepting the impossibility of eradicating gambling, and mitigating the damages by proscribing the activity within more orderly paramaters: "y pues el vicio del juego se ha vuelto en ejercicio común, mejor es que se juegue en casas principales que en la de algún oficial" (II. 49). Again, the source here could very well be Castillo de Bobadilla, 
who, despite conventional moralizing against el juego, makes a concession "en algunas casas principales (...) donde suelen juntarse a jugar, mas por via de entretenimiento y conversacion, que a juegos rezios" (II. 21). Sancho seems to accept the reality, which also involves adapting to social custom ("se ha vuelto en ejercicio común"), and the incident ends with a typically Cervantine inconclusiveness: "Agora, Escribano - dijo Sancho -, yo sé que hay mucho que decir en eso" (II.49). ${ }^{10}$

The case of the "forastero" is also shot through with casuistical discourse. It is a folkloric paradox tale, consisting of a bridge on which each traveler must truthfully state his destination and purpose, and the penalty for lying is the gallows; but what to do with the man who swears he has come to be hanged? (II. 51). The term caso returns repeatedly, as well as the modifiers dudoso and dificultoso, as Sancho contemplates how to apply positive law ("ley rigurosa"). When Sancho opts for clemency, even though rewarding the man's honesty by letting the man live would render him a "liar," he says he is merely following the precept given to him by Don Quijote ("Si acaso doblares la vara de la justicia, no sea con el peso de la dádiva, sino con el de la misericordia" II. 43). The principle of clemency in cases of doubt is also recommended by Ribadeneira (Tratado II. 12).

Other cases solved by Sancho have similarly folkloric, riddle-solving qualities. The relevance of casuistry to them resides in the application of precept and reason to clarify dilemmas. In addition to relying on general principles (e.g. clemency) to guide him, Sancho draws upon his own particular epistemology, which proves effective. The empirical emphasis of Furió Ceriol, who values

10 For more on this episode in the context of contemporary (very casuistical) debates on gambling, see Scham (190-200). For the casuistical background of the category "indiferente," see Jonsen and Toulmin, Ch. 3 and Ch. 7. The Jesuit Antonio Escóbar y Mendoza uses the concept in relation to go-betweens and pimps (alcahuetes), for example in his discussion of the role of the servant (criado), providing us, as with so many of the casos recorded in these compendia, illustrations of early modern life and rituals: "Aparejar el cavallo en que ha de yr el amo a casa de la amiga, hazerle espaldas para guardarle, poner a la amiga la mesa, guisar la comida, llevarla a casa, llevarla papeles no deshonestos, aunque si de alguna aficion, y mas que ordinaria cortesia, ministrar regalos, abrir puerta, o ventana, mostrar donde esta su amo a la amiga, darle el pie, tener la escala" (Examen y practica de confessores y penitentes, I.40). If this puts us in mind of Pármeno and Sempronio's service of love-sick Calisto (see Marlen Bidwell-Steiner's essay on La Celestina in this volume), it also reminds us that Don Quijote gave a spirited defense of alcahuetes during his discussion with the galley slaves (Don Quijote I. 22). Though the entire scene, with its euphemisms and double-talking scoundrels, presents an ironic mundo al revés, it is worth noting that Don Quijote makes the same point as Sancho's page regarding gambling: "que no le debía ejercer sino gente muy bien nacida" (II. 22). Both inclinations are seemingly impossible to eradicate; better to "civilize" them through upper-class administration. For the casuistical quality of the entire galeote scene, see González Echevarría. 
practical knowledge and is suspicious of abstract speculation and conjecture, can be seen in Sancho's solution to the case of the cane and the lent/stolen money. Furió Ceriol's observation of the "razonable memoria" of "sanguinos" (86) seems also to apply to Sancho. Noticing the transfer of the cane when the defendant swears he has returned the money to the claimant, Sancho solves the deceptive oath by having the cane broken to reveal the gold coins inside. Sancho's shrewd observation is aided by his memory of a similar case, represented by his own sort of church authority - the sermon of a country priest: "que él había oído contar otro caso como aquel al cura de su lugar" (II. 45).

An oath is sworn also by the man accused of violating the rustic "dueña" in the following case: "Dice que la forcé, y miente, para el juramento que hago y pienso hacer; y esta es toda la verdad, sin faltar meaja" (II. 45). This oath turns out to be true, as Sancho confirms by having the man give the woman his pouch of coins, and then telling him to recover it. The impossibility of the endeavor allows Sancho to judge the case conclusively: "si el mismo aliento y valor que habéis mostrado para defender esta bolsa le mostrárades, y aun la mitad menos, para defender vuestro cuerpo, las fuerzas de Hércules no os hicieran fuerza" (II. 45). A probable source for this is fray Francisco de Osuna's Norte de los estados (Seville 1531), a homiletic, practical guide to conjugal life that has much in common with the various manuales for priests and penitents circulating in the period. ${ }^{11}$ If such guides were gaining wider audiences by being written increasingly in the vernacular rather than Latin, Sancho's recollection of the priest's sermon suggests that they also permeate oral culture.

The most casuistical of the cases Sancho judges during his rounds is that of the disguised young boy and his sister, who had escaped paternal confinement. In contrast to the other cases with their folkloric and homiletic source material, these characters and their circumstances are decidedly more novelistic. As such, they also present a greater challenge to Sancho's attempt to impose order and meaning. The discovery of the young girl dressed as a boy causes general confusion, because unlike the other cases brought before him, this one is not staged by the Duke and Duchess' minions: "porque aquel suceso y hallazgo no venía ordenado por ellos" (II. 49). It thus represents a sort of unruly reality imposing itself upon the artifice and theatricality of Sancho's court. And the casuistical discourse is present from the outset: "estaban dudosos, esperando en qué pararía el caso; Sancho quedó pasmado de la hermosura de la moza, y preguntóle quién era, adónde iba y qué ocasión le había movido para vestirse en aquel hábito" (II. 49). Sancho sets about investigating the "doubtful case" by deploying a good part of the hexámetro used by confessors: Quien, que, donde,

11 See Don Quijote, eds. Morales and Soriano 1319, n. 3. For a discussion of the proliferation of such manuals, as well as an illustrative list, see O'Banion, especially 338 . 
con que, porque, como, quando. ${ }^{12}$ Among the other nuances of circumstance, the casuists strove to take into account factors such as the age, sex, social class, intention and state of mind of the person in question. These details are all duly obtained: the flustered ("turbada") young girl, daughter of the "hidalgo principal y rico" Diego de la Llana, has escaped her widower father's confinement in order to satisfy her curiosity about the world. Her transgression is having contravened "el decoro que a la honestidad se debe" (II. 49). Interestingly, a full explanation of the "sin" is not given until a sort of private space has been established, thereby increasing the confessional character of the scene: "Haga (...) apartar la gente, porque esta señora con menos empacho pueda decir lo que quisiere" (II. 49).

The girl proceeds to give an account of her case ("Es el caso ..."), explaining the father's confinement of the two siblings following their mother's death and her growing desire to see the world and its varied entertainments ("toros," "cañas," "comedias"), as related by her brother. The narration is interrupted by fits of sobbing. Her brother is then questioned separately, and his account corroborates that of his sister. The episode contains a range of assertions, motives, reactions and judgments that do not always cohere, and that reveal Sancho and his entourage (Mayordomo, Maestresala and Secretario) to be both skillful and flawed assessors of the case before them. The reality of the girl's situation ultimately escapes their comprehension, for reasons the casuists well understood.

After listening to the full account of the girl, Sancho's reaction reveals some insight into narrative efficiency:

[...] para contar esta necedad y atrevimiento no eran menester tantas largas ni tantas lágrimas y suspiros; que con decir: "Somos fulano y fulana, que nos salimos a espaciar de casa de nuestros padres con esta invención, sólo por curiosidad, sin otro designio alguno", se acabara el cuento, y no gemidicos, y lloramicos, y darle. (II. 49)

The girl agrees, attributing the narrative disorder and excess to her agitated state ("la turbación que he tenido ha sido tanta, que no me ha dejado guardar el término que debía" [II. 49]). Sancho's words echo the advice in casuistry manuals for efficient confession. In his "cuatro reglas para declarar las circunstancias," Bartolomé de Medina stipulates that details to be included are those that might alter the type of $\sin$ ("cuando mudan especie de pecado"), or potentially aggravating circumstances ("cuando agravan el pecado"); superfluous information - whether an act was committed before or after lunch, for 
example -, or information implicit in the act - the caresses and kisses during coition -, may be omitted (Breve instrucción de como se ha de administrar el Sacramento de la penitencia Ch. 9). The excess Sancho criticizes in the girl's account ("lágrimas y suspiros [...] gemidicos, lloramicos") seems to refer not only to her sobbing delivery, but also to how it affects the form and content of her story, and especially, as Sancho comments, insofar as it impedes concision. ${ }^{13}$

But does Sancho's summary get to the heart of the matter? He does seem to acknowledge the mitigating circumstances of the transgression, attributing to the siblings' disobedience and break with decorum a benign motive: "sólo por curiosidad, sin otro designio alguno" (II. 49). Of course, curiosidad is far from a simple notion in Cervantes. It is the engine of the disastrous (and casuistical) experiment in the interpolated "El curioso impertinente" (I. 33-35). In its full sense of both seeking out new knowledge and of doing something with great care, it characterizes the creative impulse itself in the prologue to the Novelas ejemplares: "por esto se cultiva, con curiosidad, los jardines" (80). Cervantes clearly portrays the girl's curiosity in a capacious sense, both as temptation that can lead to sin, but also as an imaginative incitement leading to creative costumes and sallying forth in the world (another variation, in miniature, of the work's principle theme). To return to the moral overtones, it is worth considering Azpilcueta's assessment:

Curiosidad es querer saber sobrado, o desrazonablemente, Lo qual siempre es pecado venial, ora se quiera saber assi por alguno de los cinco sentidos exteriores, ora por alguno interior, o por el entendimiento: porque es contraria a la virtud de la estudiosidad, y contra la razón. ${ }^{14}$

Manual de confessores y penitentes, fol. 248

13 To appreciate the development in his understanding of narrative economy, recall Sancho's tale about the shepherd conveying his flock of sheep across a river, which elicits the following exasperated response from Don Quijote: “ ¿Tan de esencia de la historia es saber las cabras que han pasado, por estenso, que si se yerra una del número no puedes seguir adelante con la historia?" (I. 2O).

14 See also Francisco de Toledo: "Es desordenado apetito de saber ... cosas [que] no pertenecen al que aprende. Y la estudiosidad quebranta el apetito de saber, y esta estudiosidad de tal manera refrena el apetito de saber, que haze que el hombre no quiera saber contra la razon ni dexe de saber las cosas que son necessarias conforme a ella [...] [N]o solo el conocimiento que se haze por el entendimiento, sino tambien por la imaginacion, y por los sentidos exteriores, conviene a saber, vista, oydo, \&c." (Instruccion de sacerdotes, 1596, Cap. XII). Martínez Mata notes the word's shadings in different contexts, from "knowing" ("curioso lector") to "careful," "diligent" (the "curiosos" "ingenios de la Mancha"). Cf. Scham 338, n. 64 . 
This seems to capture important aspects of the girl's curiosity, which involves both her senses and her imagination (in the interior space of her enforced enclosure), as well as Sancho's assessment that it is a venial transgression. The interesting notion that curiosity is inimical to "estudiosidad" seems to refer to its distraction of the mind, carrying it away from matters pertinent to the particular field of study. In the present case, it has distracted her from maintaining decorum as a young girl and daughter of a rich hidalgo. We will see, however, that such a definition of curiosity does not fully capture the motives of the two youth.

In comments that echo contemporary moralists' objections to reading imaginative literature, Bartolomé de Medina alerts confessors to the precariousness of hearing such cases, especially those of young women: "que muchas vezes estos tales [confesores] por hablar con ellas, sienten ciertas titilaciones y humedades sin quererlo" (Ch. 13, fol. 256). As Sancho, the Mayordomo, Maestresala and Secretario have taken the girl aside to hear her confession/ deposition, the effects feared by Medina are evident in the Maestresala:

[...] parecióle que no eran lágrimas las que lloraba, sino aljófar o rocío de los prados, y aun las subía de punto y las llegaba a perlas orientales, y estaba deseando que su desgracia no fuese tanta como daban a entender los indicios de su llanto. (II. 49)

This reaction comes just as the girl had spoken of her own "mal colocados deseos" (II. 49). As it turns out, she seems to realize the levity of her transgression, and the continuation of her account does undercut initial expectations of a grave "desgracia": "No me ha sucedido nada, ni me sacaron celos, sino solo el deseo de ver el mundo, que no se extendía más a ver las calles de este lugar" (II. 49). In fact, she expressly contradicts her earlier claim to violate the decorum of her condition (see above): "pareciéndome que este deseo no iba contra el buen decoro que las doncellas principales deben guardar a si mesmas" (II. 49 italics added). The effect of the siblings on Sancho's entourage, however, instills in the Maestresala a determination to take the girl as his wife, and Sancho to marry the boy to his daughter. The "mal colocados deseos" may better apply to the confessors than the penitents in this case.

Even though Sancho does seem to grasp the import of the girl's account, and is merciful in his judgement, his final reversion to proverbs reveals a failure fully to grasp her situation:

Y de aquí en adelante, no se muestren tan niños, ni tan deseosos de ver el mundo; que la doncella honrada, la pierna quebrada, y en casa; y la mujer 
y la gallina, por andar se pierden aína; y la que es deseosa de ver, también tiene deseo de ser vista. No digo más. (II. 49)

Sancho's attempt to encapsulate the girl's situation with proverbs and commonplaces does not correspond well to the reality of her plight brought on by the excessive measures of a mourning father who has deprived her of the world. In this sense, Sancho's formulations are similar to the partial and unsatisfactory assessments of the "shepherds" who complain of the "bella ingrata" Marcela (I.14), or the halting exemplarity of the multiple explanations given at the end of "El celoso extremeño" (Novelas ejemplares)..$^{15}$ His attempt at terse conclusion, "no digo más," stands in contrast to his acknowledgment of the complexity of the situation with gambling houses: "yo sé que hay mucho que decir en eso" (see above). For a moment, Sancho seems to revert to the injudicious application of proverbs Don Quijote had warned against earlier. But if Sancho's return to proverbs indicates a misapplication of precept, his ultimate decision to leave the governorship reveals, as we shall consider below, the emergence of a fuller understanding.

\section{Sancho as Statesman: Conscience, Intention, Self-Knowledge}

As we have suggested, the workings of casuistry are to be found throughout Don Quijote. In addition to the above-mentioned questioning of the circumstances of the galeotes' crimes (I.22), the interpolated tale of the "Curioso impertinente" is casuistical in exposition, as Anselmo calls upon his good friend for counsel in deciding how and whether to act upon his anxiety regarding his wife's virtue. The story also has clear roots in the literatura sapiencial tradition, hearkening back to the exhaustive interrogation of female chastity in the thirteenth-century Sendebar. Recounting Don Quijote's penitencia in the Sierra Morena to the barber and the priest, Sancho reacts apprehensively to the suggestion that his master might become an archbishop, upon which the barber consoles him in the following terms: "No tengáis pena, Sancho amigo [...], que aquí rogaremos a vuestro amo, y se lo aconsejaremos y aun se lo pondremos en caso de conciencia, que sea emperador y no arzobispo" (I.26). ${ }^{16}$

15 "[...]que quede en el mundo por ejemplo, si no de bondad, al menos de simplicidad jamás oída ni vista” (456). "[...] ejemplo y espejo de lo poco que hay que fiar de llaves, tornos y paredes cuando queda la voluntad libre; y de lo menos que hay que confiar de verdes y pocos años, si les andan al oído exhortaciones destas dueñas de monjil negro y tendido, y tocas blancas y luengas" ( 458 italics added).

16 Cited in Gómez Canseco, note 5. 
The passage prefigures the Barataria episodes in many ways. Sancho's concern with a religious appointment stems from his own marital status and lack of religious training, making him less suited for an ecclesiastical position than for the governorship to which he aspires. The notion of penitence also returns during Barataria, not in the form of amorous suffering (as is the case with Don Quijote in Sierra Morena), but rather with the dietary restrictions imposed by the stern doctor Pedro Recio, as Sancho bitterly complains in his letter to Don Quijote: "he venido a hacer penitencia, como si fuera ermitaño, y como no la hago de mi voluntad, pienso que al cabo al cabo me ha de llevar el diablo" (II. 51). During the earlier scene, the priest and barber judge that Sancho's belief in Don Quijote's fictions is not pernicious: "No quisieron cansarse en sacarle del error en que estaba, pareciéndoles que, pues no le dañaba la conciencia, mejor era dejarle en él, y a ellos les sería de más gusto oír sus necedades" (I. 26). The casuist's concern with conscience offers a perfunctory justification for what is of greater interest: the pleasure provided by hearing Sancho's stories. This entire interplay of confessional register ("error," "conciencia," "penitencia"), narrative efficacy and pleasure intensifies during Sancho's governorship; and it contributes to a final act of reflection that produces a remarkable desenlace.

Chiong Rivero, James Iffland and Agustin Redondo have all argued that much of the episode's transgressive force stems from who this thoughtful statesman is: as Redondo put it, "antítesis de un aristocrático, digno y grave gobernador" (1978: 56). In addition to eliciting festive laughter, the carnivalesque peasant governor takes on an unexpected dignity, which enhances the implied critique of the conventional ruling class (Redondo 1978: esp. 65-67). Alban Forcione emphasized Sancho's creative and ethical development through his narrative atop Clavileño (II. 41) and through the course of his governorship. In like manner, Redondo, deploying terminology of myth analysis, traces Sancho's rise from "helper" to "substitute for the hero," a process that culminates in the Barataria scene (Redondo 2019).

It is worth emphasizing again that Sancho's success as governor does not completely arise ex nihilo. The contemporary debates regarding statecraft articulated criteria that correspond to fundamental aspects of Don Quijote's squire. As the Spanish tratadistas strove to reject the "godless Machiavelli" while still acknowledging the possibility of a "science" of politics and a legitimate Reason of State, they placed a heightened value on empiricism and liberation from abstract and antiquated rules. ${ }^{17}$ As opposed to book learning and theoretical

17 For the general obligation to reject Machiavelli in Counter-Reformation Spain, coupled with the compelling appeal of many of his ideas, see Tierno Galván (1949) and Fernández Santamaría (1980). 
sophistication, sound natural reason on the foundation of life experience is needed to confront a complex and shifting reality. Consistent with probabilism's resistance to strict adherence to precept and majority opinion, such currents of thought give a plausibility to Sancho's fitness as governor, carnivalesque though it may be. According to Phillip II's secretary, Antonio Pérez, a representative of the "realist" and "empiricist" branch of Spanish political thinkers, a corollary to the good governor is not the schoolman, but the "shepherd, farmer, merchant, mariner: all combine nature and experience to ply their trades" (Fernández Santamaría 377). Citing the Centellas de varios conceptos (1614) of the empiricist Catalán Joaquín Setanti, Fernández-Santamaría illustrates the degree to which the casuist method had made its way from the confessional to the court: "The difficult art of ruling thas no sure reglas to serve as its foundation. Instead, what rules it has can be changed by time, circumstance (ocasiones) and the practical mind (entendimientos prácticos) of the statesmen" (377). Referring to the "art of narrating" (rather than the art of ruling), another of Cervantes' transcendent "low" characters, the dog Berganza makes a similar observation: "Pero ahora no van las cosas por el tenor y rigor de las antiguas; hoy se hace una ley y mañana se rompe, y quizá conviene que así sea" ("Coloquio de los perros" 679). And Julio Caro Baroja, critiquing Pascal's caricature of casuistry as expedience and laxism, counters that the complexity of real life calls for such an approach: "el casuista laxo se pone ante realidades de la vida" (534).

Some of the considerations touched upon above emerge already in the scenes anticipating Sancho's assumption of his post. During the Duchess' questioning of Sancho about the dudas she has regarding Dulcinea's enchantment (not least whether Sancho ever actually saw her) and his fitness for the governorship, the word "escrúpulo" is uttered three times. And Sancho summarizes his plight in the following terms:

Y si vuestra altanería no quisiere que se me dé el prometido gobierno, de menos me hizo Dios, y podría ser que el no dármele redundase en mi conciencia; que maguera tonto, se me entiende aquel refrán de "por su mal, le nacieron alas a la hormiga"; y aun podría ser que se fuese más aina Sancho escudero al cielo, que no Sancho gobernador. (II. 33)

The casuistical register ("dudas," "escrúpulos," "conciencia") emerges as Sancho explains his deception, justifies his relationship to Don Quiote, and, in a prefiguration of his great nosce te ipsum at the end of his reign, reflects upon his identity and the prospects of taking the mantle as governor. In addition to this appeal to the interiority of conscience and subjectivity, and to the 
circumstances and character traits which bind him to his master ("somos de un mismo lugar; he comido su pan; quiérole bien; es agradecido; dióme sus pollinos, y, sobre todo, yo soy fiel"), the following chapter, in which Sancho discusses hunting with the Duke, reveals a consistent casuistical discourse, and one that is instrumental in the development of Sancho's character.

The Duke's advocacy of the hunt is consistent with contemporary treatises on recreation and statecraft: "La caza es una imagen de la guerra [...] agilítanse los miembros del que la usa [...]" (II. 34). Ribadeneira promotes hunting along with sword-play, swimming, and other vigorous physical activities as of particular utility to the martial preparation and exemplary bearing of the upper classes (II. 43). Sancho's governorship hews in large part to the Counter-Reformation, anti-Machiavellian tenor of Ribadeneira, who insists on the primacy of the Catholic character of the ruler (as well as his advisers). In contrast with the tainted sophistication of the politicos, who promote duplicitous simulación and the instrumentalization of religion as a means to retain power, authentic piety cultivates a "razon natural: la qual, si con los vicios y passiones no se escurece, podra mostrar este camino á los Reyes, y alumbrarlos, y guiarlos" (Ribadeneira I. 13). In a chapter extolling peasants, Ribadeneira praises not only their productive cultivation of natural resources, but also virtues that arise from close contact with the earth - for example, a particular fitness for martial duty: "el labrador puede tomar las armas mejor que el mercader; y passar los trabajos de la milicia [...] y dormir en el suelo, porque esta curtido y hecho á ello: y como no tiene otros thesoros, ni otras riquezas, sino las que le da la tierra, pelea por ella" (II. 11). Sancho's declaration of purpose as he sets out upon the nocturnal rounds (ronda) of his realm summarizes well his affinity with such thinkers: "Pienso favorecer a los labradores, guardar sus preeminencias a los hidalgos, premiar a los virtuosos y, sobre todo, tener respeto a la religión y a la honra de los religiosos" (II. 49).

Furió Ceriol also held forth qualities of rulers and advisers that would seem to legitimize the rise of someone like Sancho Panza, including praise of the practical knowledge of laborers. But rather than the religious and providential associations of Ribadeneira's "natural reason" (producing a sort of Erasmian holy fool), Furió Ceriol subscribes to humoral theory - and, more importantly, to sound knowledge based on practical experience. He thus favors "esperiencia" over "conjetura," and promotes the following humors:

[...] o sanguino, o colérico, i no de otra complissión; por que los desta mescla i temperamento son ingeniosos, tienen razonable memoria, saben hazer discurso, tienen claro juizio, son justos, amorosos, afables, leales, benéficos, maníficos, manánimos i fuertes de su natural. (86) 
Then again, his appearance should not inspire laughter ("que no cause risa su apariencia" 121), a stipulation Don Quijote seems to appreciate when he advises his squire on his grooming and presentation at court (II. 43). ${ }^{18}$

In further discussions with the Duke following the revelations during the Clavileño episode, Sancho expresses the piety, virtuous intentions and telluric values recommended by Ribadeneira:

[...] venga esa ínsula; que yo pugnaré por ser tal gobernador, que, a pesar de bellacos, me vaya al cielo; y esto no es por codicia que yo tenga de salir de mis casillas ni de levantarme a mayores, sino por el deseo que tengo de probar a qué sabe el ser gobernador. [...] Yo imagino que es bueno mandar, aunque sea a un hato de ganado. (II. 42)

And prior to receiving the famous consejos from Don Quijote, Sancho lays claim to just the type of razon natural described by Ribadeneira: "Letras [...], pocas tengo, porque aún no sé el abecé; pero básteme tener el Christus en la memoria para ser buen gobernador. De las armas manejaré las que me dieren, hasta caer, y Dios delante" (II. 42).

Returning to his response to the Duke's advocacy of the hunt, we see that Sancho's critique of the sport combines logical reasoning with an affirmative awareness of his identity. ${ }^{19} \mathrm{He}$ reasonably points out the folly of exposing rulers to unnecessary risk in pursuit of big game, the cruelty of killing an "innocent" being ("matar a un animal que no ha cometido delito alguno"), and the frivolous time expenditure: "la caza y los pasatiempos más han de ser para los holgazanes que para los gobernadores" (II. 34). Sancho recognizes the benefits of recreation in moderation, proscribed within limits of time and place: "En lo que yo pienso entretenerme es en jugar al triunfo envidado las pascuas, y a los bolos los domingos y fiestas; que esas cazas ni cazos no dicen con mi condición ni hacen con mi conciencia" (II. 34). ${ }^{20}$ Faced with the Duke's conventional defense of the hunt, Sancho considers his current responsibilities and his own particular character, and ultimately follows his conscience. The

18 Bleznick suggests that both Ribadeneira and Furió Ceriol were familiar to Cervantes. Márquez Villanueva offers a concise account of Sancho's humoral suitability: "los de cerebro húmedo, y de un modo especial los gruesos y panzudos, son dormilones y pacíficos, además de ciclotímicos o temperamentalmente inestables, pero de gran inteligencia práctica, lo cual los vuelve muy aptos para las tareas de gobierno aun si carecen de letras formales" (56-57).

19 On humanist thought behind Sancho's rejection of hunt, see Margaret Greer.

20 For a discussion of Sancho's views vis a vis contemporary thought on the benefits and risks of recreation, see Scham (2014). 
appeal to conscience is combined with the assertion that, although certainty may be impossible, the intention with which one acts is important:

Haya lo que hubiere [...] más vale al que Dios ayuda que al que mucho madruga, y tripas llevan pies, que no pies a tripas; quiero decir que si Dios me ayuda yo hago lo que debo con buena intención, sin duda que gobernaré mejor que un gerifalte. (II. 34)

The reliance on good intention is emphasized in two of the most important casuistical guides of the sixteenth century, Martín de Azpilcueta's Manual de confesores y penitentes (1554) and Bartolomé de Medina's Breve instruction de como se ha de administrar el Sacramento de la Penitencia (1580). Sancho purports to adhere to prudence and virtue in his actions, grounding his judgement in Catholic piety and a humble - if exuberant - knowledge of self: "Vístanme [...] como quisieren; que de cualquier manera que vaya vestido, seré Sancho Panza" (II. 42). ${ }^{21}$

\section{Conclusion}

As Don Quijote asserted while counselling his squire, one of the most difficult achievements is the gaining of self-knowledge: "has de poner los ojos en quien eres, procurando conocerte a ti mismo, que es el más difícil conocimiento que puede imaginarse" (II. 42). The classic nosce te ipsum is also found in Ribadeneira, who maintains that it is particularly challenging for a prince, who must be able to distinguish between false and true friends, dismiss the empty praise of sycophants, and avoid being blinded by pride and amor propio (II. 29, "Como se deve guardar el Principe de los lisongeros"). ${ }^{22}$ Sancho's realization is expressed in his typical idiom:

21 For the "probabilistic" quality of such deliberation - recognizing uncertainty and turning to conscience and intention -, see Jonsen and Toulmin, who note that the Jesuits "approached moral questions in the spirit of Aristotle and Aquinas rather than of Plato and Augustine: the problem that occupied them was how to choose a course of action prudently and virtuously, rather than how to ascend to a vision of eternal truth" (Jonsen and Toulmin 148).

22 Furió Ceriol also stressed the importance of surrounding oneself with people who would speak the unvarnished truth (Ch. 4). The role of authentic friendship in achieving self-knowledge is examined in the tradition of "literatura sapiencial," including Petrus Alfonsi's Disciplina clericalis (see the first dialogue). 
Yo soy del linaje de los Panzas ... Quédense en esta caballeriza las alas de la hormiga, que me levantaron en el aire para que me comiesen vencejos y otros pájaros, y volvámonos a andar por el suelo con pie llano. (II. 53)

If Sancho displays a degree of amor propio here, it is a pride over his humble state. He is, on the one hand, remaining faithful to type. But this reaffirmation of telluric values ("volvamos a andar por el suelo") is all the more notable as it comes after Sancho has achieved his high ambition of governing. As Cascardi put it, the entire sequence, following the lofty perspective atop Clavileño (II. 41), involves "politics brought down to earth;" but this process occurs in the qualified manner we have identified as a hallmark of casuistry: "rather than move us in a seamless fashion from the realm of theory toward the world of practice, these episodes magnify the over-simplification inherent in the very idea of such a progression" (Cascardi 139).

Sancho acquits himself well as governor, but he also experiences the unsavory aspects of life at court, and decides that he prefers his old mode of existence. But this "old" identity is a composite: not only his humble peasant self, but also the escudero, an identity fortified by the friendship and adventure he shares with Don Quijote ("entre alegre y triste venía caminando sobre el rucio a buscar a su amo, cuya compañía le agradaba más que ser gobernador de todas las ínsulas del mundo" II. 54). This awareness of self, gained through experience, brings an ethical development, as displayed in his judgements and in his debate with the Duke regarding the hunt. The overt conceptual content of the episode - drawing, as we have seen, upon contemporary political and religious tracts as well as classical philosophical postulations - is appropriated by Sancho in his own idiosyncratic manner, mixed in with the earthy discourses of oral culture and applied to unexpected and perplexing events. Ortega y Gasset's famous pronouncement that Don Quijote reveals a modern notion of identity - "Yo soy yo y mi circunstancia" - applies to Sancho as well. The circumstances of Barataria and his recent experiences with Don Quijote allow aspects of his persona to express themselves in sometimes surprising ways. And by this point in the novel, Cervantes has imbued us readers with a casuistical "habit of mind." Faced with the peculiar turns taken by characters as central as knight and squire, and from the lowly Maritornes to the "beautiful ingrate" Marcela, to the curate as he pronounces his literary judgements, we find that our initial understanding will most likely undergo modification as we learn more about them. Sancho Panza becomes similarly aware of the complexities of judgement as he realizes his ambition as statesman, and ultimately arrives at a deeper understanding of himself. Following the intricate caso de conciencia that his experience as governor comprises, his new understanding forms the basis for ethical action - and for novelistic development. 


\section{Works Cited}

Alfonsi, Petrus. Die Kunst, Vernünftig zu Leben (Disciplina Clericalis). Trans. Eberhard Hermes. Zürich: Artemis, 1970.

Avalle Arce, Juan B. "La ínsula Barataria: la forma de su relato." Anales De Literatura Española 6 (1988): 33-44.

Azpilcueta, Martín de. Manual de confessores y penitentes (1554). https://bvpb.mcu.es/ es/consulta/registro.do?id=413671.

Bleznick, Donald A. "Don Quijote's Advice to Governor Sancho Panza." Hispania 40.1 (1957): 62-65. Stable URL: https://www.jstor.org/stable/33567o.

Borges, Jorge Luis. "La conducta novelística de Cervantes." El tamaño de mi esperanza/ El idioma de los argentinos. Buenos Aires: Random House Mondadori, 2012.

Byrne, Susan. Law and History in Cervantes' Don Quixote. Toronto: University of Toronto Press, 2012.

Caro Baroja, Julio. “Probabilidades, laxitudes y corrupciones.” Las formas complejas de la vida religiosa: religión, sociedad y carácter en la España de los siglos XVI y XVII. Madrid: Akal, 1978: 517-550.

Cascardi, Anthony J. Cervantes, Literature and the Discourse of Politics. Toronto: University of Toronto Press, 2016.

Castillo de Bobadilla, Jerónimo. Política de corregidores (1597). Ed. Benjamín González Alonso. Madrid: Instituto de Estudios de Administración Local, 1978.

Cervantes Saavedra, Miguel de. El ingenioso hidalgo Don Quijote de la Mancha. Eds. Justo García Soriano y Justo García Morales. Madrid: Aguilar, 1981.

Cervantes Saavedra, Miguel de. Don Quijote de la Mancha. Edición del Instituto Cervantes, dir. Francisco Rico. https://cvc.cervantes.es/literatura/clasicos/quijote/ default.htm.

Cervantes Saavedra, Miguel de. Novelas ejemplares. Ed. Jorge García López. Barcelona: Crítica, 2005.

Corteguera, Luis R. "Sancho Panza Wants an Island: Cervantes and the Politics of Peasant Rulers." Romance Quarterly 52.4 (2005): 261-70.

Chiong Rivero, Horacio. "Insula de buen gobierno: el palimpsesto guevariano en 'las constituciones del gran gobernador Sancho Panza'. Cervantes: Bulletin of the Cervantes Society of America 28.1 (2008): 135-165.

Escobar y Mendoza, Antonio. Examen y practica de confessores y penitentes. Paris: Antonio Bertier, 1665 (53rd edition). вNм R/4273. http://bdh-rd.bne.es/viewer .vm?id=ooooo79368\&page $=1$.

Fernández-Santamaria, José A. "Reason of State and Statecraft in Spain (1595-1640)." Journal of the History of Ideas 41.3 (1980): 355-379.

Forcione, Alban. "Cervantes' Night-Errantry: The Deliverance of the Imagination." Bss 81.4-5 (2004): 451-73. 
Furió Ceriol, Fadrique. El concejo y consejeros del príncipe. Obra completa. Co-directors Henry Mechoulan and Jordi Pérez Durà. Valencia: Ediciones Unesco, 1996.

Gilbert-Santamaria, Donald. "Sancho's 'Insula' and the Politics of Empire." Hispanófila 150 (2007): 15-25. www.jstor.org/stable/43807465.

Gómez Canseco, Luis. "Probabilismo en Cervantes: La gran sultana como caso de conciencia." Criticón 109 (2010): 167-86.

González Echevarría, Roberto. Love and the Law in Cervantes. New Haven: Yale University Press, 2005 .

Greer, Margaret R. "Diana, Venus and Borrowed Dogs: On Hunting in Don Quixote." Cervantes y su mundo (III). Eds. Robert A. Lauer and Kurt Reichenberger. Kassel: Reichenberger, 2005: 201-22.

Iffland, James. De fiestas y aguafiestas: risa, locura e ideología en Cervantes y Avellaneda. Madrid: Iberoamericana, 1999 .

Jonsen, Albert R. and Stephen Toulmin. The Abuse of Casuistry. Berkeley: University of California Press, 1988.

Kallendorf, Hilaire. Conscience on Stage: The Comedia as Casuistry in Early Modern Spain. Toronto: University of Toronto Press, 2007.

Lyons, John D. Exemplum: The Rhetoric of Exemplarity in Early Modern France and Italy. Princeton: Princeton UP, 1989.

Márquez Villanueva, Francisco. Cervantes en letra viva. Barcelona: Reverso Ediciones, 2005 .

Martínez Mata, Emilio. Cervantes comenta el Quijote. Madrid: Cátedra, 2008.

Maryks, Robert A. "Rhetorical Veri-similitudo: Cicero, Probabilism, and Jesuit Casuistry." Traditions of Eloquence: The Jesuits and Modern Rhetorical Studies. Eds. Cinthia Gannett and John C. Brereton. Fordham: University Press, 2016.

Medina, Bartolomé de. Breve instrucción de como se ha de administrar el Sacramento de la penitencia (1580). BNM (R/38567) http://bdh-rd.bne.es/viewer.vm?id=0oooo 66803 \&page $=1$.

O'Banion, Patrick J. “'A Pries Who Appears Good': Manuals of Confession and the Construction of Clerical Identity in Early Modern Spain." Dutch Review of Church History 85 (2005): 333-348.

Ortega y Gasset, José. Meditaciones Del Quijote. Ed. Julián Marias. Madrid: Catedra, 1984.

Percas de Ponseti, Helena. "Los consejos de don Quijote a Sancho." Cervantes and the Renaissance. Ed. Michael D. McGaha. Easton, PA: Juan de la Cuesta, 1980: 194-236.

Quintana Tejera, Luis. "Análisis literario de los consejos que da Don Quijote a Sancho antes de ir a gobernar la ínsula Barataria: segunda parte del Quijote." Espéculo: Revista De Estudios Literarios 34 (2006) [no pagination].

Redondo, Augustin. "Sancho Panza, de ayudante del héroe a sustituto del héroe." $\mathrm{eHu}$ manista/Cervantes 7 (2019): 26o-74. 
Redondo, Augustin. "Tradicion carnavalesca y creacion literaria, del personaje de Sancho Panza al episodio de la insula Barataria en el Quijote." Bulletin Hispanique 8o (1978): 39-70.

Ribadeneira, Pedro de. Tratado de la religion y las virtudes. Madrid: P. Madrigal, 1595. https://bvpb.mcu.es/es/consulta/registro.do?id=417725.

Scham, Michael. Lector Ludens: The Representation of Games and Play in Cervantes. Toronto: University of Toronto Press, 2014.

Sullivan, Henry. "Moral Probabilism and Casuistry in Spain during the Counter Reformation." Tirso de Molina and the Drama of the Counter Reformation. Amsterdam: Rodopi, 1976: 40-51.

Tierno Galván, Enrique. El tacitismo en las doctrinas políticas del siglo de oro español. Murcia: Sucesores de Nogués, 1949.

Toledo, Francisco de. Instruccion de sacerdotes, y suma de casos de conciencia (1616). вNм (U/7263) http://bdh-rd.bne.es/viewer.vm?id=ooooo10529\&page=1. 


\title{
The Lawyers' Tales: Legal Casuistry and the Spanish Golden Age Novella (Cristóbal Suárez de Figueroa, Alonso de Castillo Solórzano)
}

\author{
Mechthild Albert
}

\begin{abstract}
This contribution examines the relationship between casuistry and narrative literature in the Siglo de Oro with particular attention to legal contexts. In this respect, $E l$ pasajero (1617) by Cristóbal Suárez de Figueroa proves to be an ideal object of research, since the author, as a jurist, displays casuistic thinking, argumentation and procedure. The rather pragmatic and didactic character of this hybrid text is contrasted with novellas from the collection Huerta de Valencia (1629) by Alonso de Castillo Solórzano, whose intradiegetic storytellers are likewise characterized by their academic professions, including a lawyer.
\end{abstract}

\section{Keywords}

Casuistry - legal contexts - narrative literature - hybrid genre - novella - Cristóbal Suárez de Figueroa - El pasajero - Alonso de Castillo Solórzano - Huerta de Valencia

This contribution examines the relationship between casuistry and narrative literature in the Siglo de Oro, with particular attention to legal contexts. In view of the increasing importance of legal administrative structures during the reign of Philip II and the "legalist turn of mind" in the Baroque era, William Childers in 2011 (326) named such a focus as a desideratum for research, ${ }^{1}$ which will be addressed here within the limits of a concrete case study. In this context, the hybrid text El pasajero (1617) proves to be an ideal object of investigation, especially since the author himself, as a jurist, displays casuistical thinking, argumentation and procedure. The transdisciplinary significance of casuistry (cf. Bidwell-Steiner \& Scham, in this volume), which characterizes the mental

1 "Another topic of great interest would be the underlying commonalities between casuistry [...] and the unprecedented expansion of the legal system during the reign of Philip II" (Childers 326). 
habitus of Counter-Reformation Spain, is reflected in the narrative characters of the text, identified by their respective professions and their place in life. The work's hybridity, which combines humanistic dialogue and autobiographical narrative, picaresque and pastoral novel, produces varied perspectives on the different dilemmas represented. Thus a wide range of casuistical narratives unfold, occasionally in the vicissitudes of life stories, mostly in shorter forms like exempla or anecdotes, and rarely with the elaborate arrangements and dramatic intensification reminiscent of contemporaneous novels. The rather pragmatic, demonstrative and didactic character of El pasajero will be contrasted with novellas from the collection Huerta de Valencia (1629) by Alonso de Castillo Solórzano (1584-1647), whose intradiegetic storytellers are likewise characterized by their middle-class, academic professions, including that of a lawyer.

According to the high level of development of a genre reaching its peak in these years, Castillo Solórzano's novellas are very elaborate. Comparable to the comedia, they present casuistical decision-making, which, however, is not conditioned by a professional knowledge, although the intradiegetic narrators are identified by their respective professions. Rather, these conflicts seem to correspond to a primarily religiously conditioned 'casuistical mentality' of the Counter-Reformation, where only confessors are still able to distinguish between good and evil. ${ }^{2}$

In contrast, the intercalated narratives of $E l$ pasajero are rather simple stories, reminiscent of the exemplary character of the traditional cuentos described by Maxime Chevalier, and drawing on legal casuistry. The use of the latter can be explained with reference to the author as well as to the narrator figure of the Doctor (and the Maestro), who both have professional training as lawyers.

The comparison is intended not only to consider the question of the possible disciplinary influence of narrative casuistry, but also to reflect upon Karlheinz Stierle's argument for a genre development from the exemplum to the novella. The present essay's title, "The Lawyers' Tales", is an evident reference to Geoffrey Chaucer's Canterbury Tales (late 14th century) in which the "Man of Law" is both the representative of an ideal understanding of jurisprudence (comparable to the Doctor in El pasajero) and the narrator of a love story (like the lawyer Micer Hortensio in Huerta de Valencia).

As will be shown, in the two collections of novellas, two different tendencies of linking narrative and casuistry can be discerned: a more exemplary

2 See Londoño. 
juristic-secular form and a dramatically sharpened, literary form which might be associated rather with the religiously-influenced cases of conscience.

The author of El pasajero (1617) is the writer and lawyer Cristóbal Suárez de Figueroa (1571-after 1644). ${ }^{3}$ Born in Valladolid, he was awarded a doctorate in both secular and ecclesiastical law at the University of Pavia in 1594 and held various legal offices during his professional life, including auditor, abogado fiscal, contrascriptor, juez and comisario (Pelorson 394, 397). A man of letters, he was not only feared for his controversial reviews, but also known as a translator and editor of important Italian works such as Guarini's Pastor fido (1590/1602 and 16o9) and Tommaso Garzoni's encyclopedic Plaza universal (1585/1615). As a former Jesuit pupil he contributed to the spread of the order's casuistically informed ratio studiorum (Jalón 74), not least in his pastoral novel La constante Amarilis (16o9) and hybrid prose text El pasajero (1617). Already in its subtitle, "Advertencias utilísimas a la vida humana," this miscelánea signals its didactic intention, whose essential vehicle is exemplary narrative. And in the prologue "Al lector" the author states: "Es mi disinio refrescar las memorias con la fuerza de avisos tan útiles, con la enseñanza de documentos tan necesarios, asestando la artillería de la razón (hecho primero alarde de bueno y malo) contra las torres de propias confianzas" (368). Structurally, the work consists of ten chapters in dialogue form, known as "Alivios", which deal with current topics of public interest, such as law and literature, ${ }^{4}$ religion and war, social change and standards of courtesy. The four protagonists of the dialogue, who meet during a journey by ship from Spain to Italy (emphasized by the genre designation "Alivio de caminantes" - see also Joan Timoneda's novella collection $E l$ sobremesa y alivio de caminantes), are characterized by their respective professions. Together they represent, on the one hand, the work's contemporaneous recipients, the readership of the "nueva nobleza" (cf. Romero-Díaz), ${ }^{5}$ and, on the other hand, two outstanding examples of casuistically-oriented careers: a "maestro en Artes y profesor de Teología", a young soldier named don Luis, the silversmith Isidro and a "Doctor of Both Laws" ("ambas Prudencias", 369), who dominates the conversations and can be identified as the author's alter ego.

3 For a detailed biography see Pelorson.

4 For these particular concerns, see Albert.

5 Suárez de Figueroa refers to this culturally significant social class as "nueva caballería" (397, 399 ) and discusses in detail its associated aspects of social mobility (397-400). 
Their speeches and life accounts are part of a poetics of the exemplum ${ }^{6}$ that determines Suarez de Figueroa's understanding of the novella:

Las novelas, tomadas con el rigor que se debe, es [sic] una composición ingeniosísima cuyo ejemplo obliga a imitación o escarmiento. No ha de ser simple ni desnuda, sino mañosa y vestida de sentencias, documentos y todo lo demás que puede ministrar la prudente filosofía. (412)

In the tradition of novelistic wisdom literature, the moral teachings of the exemplum ("ejemplo") are here, as in Conde Lucanor, synthesized by a thoughtprovoking sentence or maxim. At the same time, the function of role models whether in history, literature or contemporary reality - is emphasized. In this sense the exempla serve as rhetorical arguments in terms of the docere and movere of moral development, reform and lifestyle:

Mueven los ejemplos con singular eficacia, siendo instrumentos bastantísimos para enfrenar las más desenfrenadas costumbres. Así, es justo escoger para la propia utilidad varones de ajustada conciencia y sana dotrina, por donde guiar obras, pensamientos y acciones. (642)

The rhetorical use of exempla can be identified, in particular, in the priest's professional practice, as indicated by some of the titles from the preacher's reference library, which are mentioned at the end of a long excursus on pulpit rhetoric and are particularly revealing in the semantic overlap of key terms: "Asimismo sería bien tener algunos librillos de cosas comunes, que aprovechan infinito. Tales son: Exempla virtutum et vitiorum, Similitudines Sacrae Escripturae, Summa Conciliorum, Ejemplos de Marco Marulo y semejantes" (463).

The life stories of El pasajero's four protagonists and another picaresque figure illustrate the extraordinary social mobility in this moment of the early modern period, and provide patterns of action for how the ingenium, temperament, and virtù of each individual can confront Fortuna's vicissitudes ("maravillosos altibajos"). The autobiographical accounts, therefore, provide models: existential models, as one faces the ups and downs of fate in the sense of Petrarch's Remedia (cf. Alivio IX), but also more specific models of professional careers. In this sense, the Maestro comments on the autobiographical narrative of an innkeeper as an individual and at the same time representative example:

6 For a genre history of the exemplum see von Moos. 
¡Válgame Dios! Si se pudiesen escribir los sucesos de muchas vidas, ¡qué silva de varia lección se hallaría en ellas! Maravillosos altibajos había tenido este hombre en la suya hasta entonces: labrador, soldado, religioso, tercero, valiente, bodegonero, y la última dignidad, de quién sólo se podía parar en horca ó galera. $(567)$

Such "sucesos" and "maravillosos altibajos" comprise casuistical "casos." The Maestro's professional life, ranging from medicine and jurisprudence to theology, covers the entire spectrum of academic careers in the Siglo de Oro, which are likewise significantly influenced by casuistry. As the son of a doctor, his father compelled him to continue the family tradition. However, just a few terms at the University of Alcalá made him realize his lack of affinity with this profession and change his field of study, which he justified with the Christian's freedom of will: ${ }^{2}$

Con esta declaración de mi voluntad delante, quisiera saber, profesando cristiana religión y siendo la propia conciencia el gobernalle de cualquier hombre que desea salvación, con qué seguridad de la mía pudiera engolfarme en el grande océano de lo propuesto. ¿Yo ensayarme primero en los pobres? ¿Yo cometer indignos robos en la miseria de los mendigos? (450)

His father kept urging him to practice the lucrative profession, which provides an opportunity for a satirical reading of the estates, since he claims it is enough to master "alguna cantidad de aforismos y brocárdicos", "que en la ciencia médica sirven de lugares comunes", because "esta vida es toda artificio" (449). Yet, the son proves his moral integrity by his rejection of the medical profession, invoking his conscience. As an alternative, he now strives for the socio-politically significant career of "Leyes y Cánones" - "profesión noble, ilustre, vida y alma de las ciudades, conservación del mundo" (451) -, which at the same time signifies a gain in prestige. Just as the father yields to the son's rosy visions of a future with a bright career in the legal profession, "donde, en entrando, lloverán tan grandes mercedes, que, no sólo será fácil colocarme en

7 The definition by Antonio Fernández Cano is informative in the present context: "Casuística procede de la palabra latina casus: evento imprevisto, azaroso, fatídico, sin precedentes. En terminología legal, casus significa: hecho preciso, real o supuesto." (490).

8 Childers emphasizes this with reference to the probabilism of a Francisco Suárez: "[...] in doubtful cases a confessor must respect penitents' unalienable possession of free will (liberum arbitrium)" (318). At the same time, the question of freedom of will in conjunction with predestination and Grace represents an initial starting point for questioning probabilism (cf. Fernández Cano 502). 
perpetua silla occidental o antártica, sino en las mejores audiencias ó chancillerías españolas" (451), he passes away, leaving the student to an uncertain fate, "lleno de irresolución y ambigüedad" (451). Faced with economic hardship, he decides, without the slightest vocation, to study theology, to which he devotes himself with great zeal - "con el ardor que me infundía el menester" (451) - in expectation of social and financial security: "por el seguro premio que suele alcanzar su eminencia en las oposiciones así de cátedras como de dignidades" (451). As an unqualified but influential competitor blocks his further advancement, - he decides personally to resolve the situation in Rome, the center of religious power - "cabeza de la Iglesia [...] y mar profundo, donde las redes de letras y méritos sacan copioso número de diversas remuneraciones, pescados de segura duración" (452). It is this circumstance which results in his status as one of the 'passengers'.

Complementary to the figure of the Maestro is the Doctor, alter ego of the author and protagonist of the present dialogues. As the quintessential "pasajero" he represents the homo viator, an allegory of the impermanence of the conditio humana; on the other hand he embodies the concrete historical situation of an individual in the interplay of jurisprudence and literature, between both shores of the Spanish Mediterranean. ${ }^{9}$ The Doctor's career embodies the connection between science and experience, theory and practice, since he is a graduate of the "facultad de ambas Prudencias, con título de doctor, aunque más docto en experiencia y comunicación de naciones" (xv).

The interaction of theory and practice refers to the dialectic of induction and deduction, which is constitutive for casuistry as a "practical application of moral principles to specific cases" (Childers 317 ) and the disciplines it shapes. ${ }^{10}$ This is also underlined by a remark of the young soldier don Luis, the representative of vita activa, who points to the need for complementing scholarly writing with "uso," so that people, thanks to these examples, can immediately apply their knowledge as captains to steer through the perils of life:

Sábese ser el uso, casi en todo, el maestro más cierto y mejor; ni hay cosa tan digna y loable como beneficiar a otros con ser instrumento de sus bienes y luz de sus yerros. Igualo este fruto al de los escritos, en cuya virtud muchas cosas pasadas que por ningún modo podrían haber llegado a nuestra noticia, mirándolas como en espejo juntas y recogiendo dellas lo que nos conviene, amaestrados con ejemplos osamos con más seguridad,

$9 \quad$ See "La double signification du titre" (Pelorson 410-412).

10 On casuistry as "ciencia aplicada que investigaba hechos particulares aplicando principios preestablecidos con el objeto de obtener normas que pudiesen gobernar la acción", see Fernández Cano 491-492. 
como pilotos práticos, entrar en los no antes sulcados piélagos o caminadas sendas de la vida. (373)

When it comes to the literary ambitions of the 'passengers', the lawyer, el Doctor, wants to entrust the soldier Don Luis with the writing of exemplary historical episodes precisely because of his practical experience of life, since historiography is the discipline in which theory, science and pragmatics, lawfulness and individual fates form an ideal combination:

Doctor. [...] la más digna de todas las lecciones viene a ser la de Historia, por aprovechar con la narración de públicos negocios o particulares acciones, no comunes, sino singulares y famosas. Por eso concluyen comúnmente ser la misma testimonio de los tiempos, luz de la verdad, vida de la memoria, maestra de la vida y mensajera de la antigüedad. (413)

With regard to this casuistical understanding of history as magistra vitae, don Luis' alleged deficit, namely the lack of relevant (humanistic) scholarship, proves to be an advantage that enables him to apply historical lessons of both representations of exemplary "casos" in the service of truth:

DON LUIS. ¿Por qué camino, según eso, pudiera yo sacar a luz historia acertada, si carezco de erudición, de inteligencia y prática para narrar no solamente los hechos, sino rastrear también la razón con que se hicieron, y juntamente los consejos y motivos que pudieron intervenir en los casos? Sin esto, son menester papeles; que escribir sin comprobar antes es propio de fábula que historia. (413)

In doing so, the author makes it clear that historiography is not only concerned with the facts of the illustrative "casos" in question, but also with their circumstantial contextualization, a procedure clearly marked by casuistry, as expressed in Azpilcueta's hexameter "quien, que, donde, con que, como, quando" (Bidwell-Steiner \& Scham, in this volume).

In Suárez de Figueroa's work, we find repeated moralistic analysis of human characteristics and behavior, for example, in the distinction between two forms of ignorance (590), friendship ("amistad de costumbre" vs. "amistad de razón", 470), and wrath ("ira virtuosa" vs. "vengativos y coléricos", 6oo-6o1). The dialogue about this vice between the Doctor and the Maestro is particularly 
revealing with regard to the argumentative use of exempla and casus, including their corresponding maxims: while the theologian refers back to historical examples provided by philosophical or religious authorities, apparently taken from Cesare Rao's Invettive, orationi, discorsi [...], (109v-116r), the jurist reports a contemporaneous event which he heard from an eyewitness, but also concludes with a quotation from Seneca. In both cases the narration is coupled with a mnemonic. The starting point is the fundamental meaningfulness of natural affect, which is compared to the steel of a blade, ${ }^{11}$ whose morally good or reprehensible use, in the casuistical sense, depends on the goal, purpose and context:

Doctor. [...] Es a propósito enojarse sólo consigo mismo de las cosas mal hechas; que con este fin la Naturaleza, que ninguna cosa hizo ni ordenó sin causa, mezcló entre nosotros este afecto. De suerte que, afrentado cualquiera de lo que hubiere cometido contra el Criador y su criatura, se emiende y corrija con este ardor, corrido de lo pasado. En tales casos es la ira virtuosa, justa y alabada, como efeto natural, y así, santo y perfeto el enojo en quien preceden estas causas. Hállase puesta (dice un curioso) la ira en los humanos entendimientos como el acero en la puntay corte del cuchillo, para que corte donde y cuando sea menester. (6oo)

Wrath is an emotion that plays a central role, in particular, in the medieval mirrors for princes, since a ruler is only capable of ruling justly if he knows how to control his affects. In this tradition, which usually takes the form of doctrinal dialogues between rulers and philosophers, the Maestro contributes two "ejemplos admirables" to the discussion over this vice, "[que] suelen ser comunes desta materia" (6oo). He begins with the famous advice of Poseidonius to Emperor Augustus, who is said to have asked the philosopher for "alguna sentencia digna de eterna memoria" before his return to Greece: ${ }^{12}$

Cuando te veas (respondió) vencido del furor, pasión digna de ser aborrecida de cualquier hombre, principalmente de príncipes, que han de ser señores, no siervos, antes de decir o hacer alguna cosa recita todas las letras del abecé. (6oo)

\footnotetext{
11 While Rao (114r) attributes this observation to a "celebre \& approvato autore Catolico", Suárez de Figueroa (6oo) attenuates the reference to the expression "dice un curioso." 
The second example is St. Ambrose's rebuke to Emperor Theodosius after a massacre driven by wrath. Ambrose denied the ruler access to the Cathedral of Milan and urged him to repent, since, apart from the act of "inhumanidad," he had lacked the fear of God, the supreme virtue of a ruler, who is subject to the will of God just as the most inferior of his subjects. The wrath of God is also recalled, being unleashed by sinful humanity, but nevertheless appeased by righteous individuals (like Noah or Lot): "No olvides que, así como Nuestro Señor se aíra, se embravece y enoja por la culpa, también se aplaca, se amansa y humilla por la penitencia" (6o1). The ruler obeys the admonition of the churchman - "Vuélvete a tu palacio, y alli, con verdadera contrición, entre ceniza y silicio ejercita los actos dignos de penitencia" (6oo-6o1) -, which may have been understood by contemporaneous readers in terms of Counter-Reformational piety and penitential practice. ${ }^{13}$ When the Emperor visits the Cathedral at Christmas, after months of retreat, the Bishop of Milan grants him absolution on the condition that a new law be enacted with the aim of preventing death sentences passed under the influence of wrath (6o1).

In these two historical exempla, the recommended reflection periods of, respectively, seconds and days for controlling an outburst of rage are praised by the Doctor as "dos remedios para domar, señorear y vencer el más colérico accidente que pueda mover guerra a la razón, como su capital enemigo" (6o1). At the same time, he establishes a topical connection by denouncing duels out of offended pride as a new form of excessive, destructive rage. The "caballeretes de ahora" respond to the slightest insult like a viper in order to take revenge by force of arms according to their code of honor: "Juzgan de ánimo vil no vengarse de toda intención, cuanto más de cualquier obra que se enderece a su agravio" (6o1). In contrast, he demands Christian forgiveness ("perdonar injurias") as an exemplary behavior, which he illustrates with an anecdote that took place in Trujillo and that he learned from an eyewitness, thus verifying its truth. The incident combines the specific with the general, the individual behavior with the moral norm:

13 In a different passage the Maestro also mentions the Grace of God towards the repentant sinner and the postponement of his wrath: "Esta confianza, pues, no ha de perder el bueno que entre muchos malos anda en un mismo navío por la mar. Debe entender que, aplacada su justa indignación, perdonará Dios a los de mala conciencia que con él van, dándoles tiempo de penitencia y emienda (cosa que está obligado a pedir el que menos pecador se sintiere), y que, dado que por su perseverancia en el mal quiera Dios castigarlos, dará evasión de aquel peligro a los buenos, reservando la ejecución de su ira para otro tiempo" (481-482). 
Contome [sic], como testigo de vista, un caballero de Trujillo, nieto del memorable García de Paredes, un caso sucedido en aquella ciudad, dignísimo de quedar grabado con letras de oro para ser en todas edades ejemplo de vengativos y coléricos. (6o1)

The everyday case ("como es costumbre") begins with a dispute at a ball game between aristocratic figures, which escalates dramatically as a servant of the opposing side insists on the right of his master, whereupon the offended person draws his sword. However, at the last moment, the weapon already on the chest of the opponent, he pauses to renounce the bloodshed in Christ's name:

Asiole el agraviado de un brazo, y desenvainando con notable presteza la daga, le arrimó la punta al pecho, diciendo al querer ejecutar: Perdónote por Jesucristo; que así lo manda su Majestad. Con esto dejó libre al asido $\mathrm{y}$ atónitos a los circunstantes, por ver tan grande valor y generosidad de ánimo, ya que en ninguna otra cosa se conoce y manifiesta tan de veras como en perdonar las injurias. (6o1)

With this position, Suárez de Figueroa takes sides in the "diálogo de sordos que se mantuvo a lo largo del Siglo de Oro entre impugnadores y defensores de la ley del duelo" (Chauchadis 108), ${ }^{14}$ in accordance with the prohibition of duels issued by the Council of Trent under threat of excommunication. ${ }^{15}$ The renunciation of violence also illustrates in many ways the poetological affinity between anecdote, case, novella and drama. The unique and at the same time generalizable nature of this extraordinary action as the epitome of courage and generosity ("tan grande valor y generosidad de ánimo") is underlined by the presence of an audience and its reaction ("atónitos"). The episode combines the exemplary, dramatic narrative with an aphorism, whereby this moral quintessence, the act of grace, refers simultaneously to the two highest authorities, the secular and the metaphysical, which, within the framework of the

14 In addition to pragmatic and moralistic texts, Chauchadis uses the comedia in particular as an example of the highly differentiated casuistry of "casos del duelo" or "casos de honra". Evidence of Christian renunciation of violence in situations of "desafío" can be found on pages $86,87,97 \mathrm{f}$., 102 .

15 For more on Suárez de Figueroa's opposition to duelling, see also the corresponding chapter "Discurso LXX. De los duelos y desafíos por carteles y padrinos de campo" in his Plaza universal de todas las ciencias, whose conclusion states: "Estas son las leyes de la honra del mundo, a quien dan semejante nombre los mal considerados: con que se da fin a la inicua materia del duelo, puesto aquí por curiosidad, y ya en nuestros tiempos reducido como merece su total ruina: pues casi en ninguna Provincia o ciudad es admitido, ni tiene lugar" (553). 
Catholic monarchy of the Siglo de Oro, mutually reinforce each other. ${ }^{16}$ The contemporaneous contribution from the jurist's field of experience is finally concluded, once again, by a scholarly quotation from Seneca: "Quien déstas [i.e. injurias] se acuerda (dice Séneca) pierde la virtud de la memoria” (6o1).

The relationship between ruler and philosopher or advisor known from the mirrors for princes ${ }^{17}$ is prevalent in the Siglo de Oro. Yet, in accordance with the salient function that jurisprudence - alongside religion - plays as the leading discipline of the Habsburg Empire, the role of advisor is increasingly taken over by jurists. The "rey sabio" requires the "servicio de los sabios" in the interest of state affairs, which guarantees the combination of "sabiduría" and "virtud," theory and practice, "siendo de contino compañeros en el gobierno la ciencia y prática" (392). The political system therefore needs lawyers as advisors in cases of doubt which entail casuistical thinking and action:18

[...] es importantísima al que administrare justicia la prudencia, guía y madre de todo lo bueno, y derecha razón de las cosas agibles, siendo general en todos la necesidad de la ajena. Requiérese, sobre todo, el consejo, que es bien pensada razón de lo que se debe hacer, buen aviso que se toma sobre casos dudosos. (392)

With regard to co-responsibility in government, the lawyer Suárez de Figueroa sketches an ideal image of the highest judges as the right hand of the "sabios gobernadores".19 As representatives of the interests of the people, they need to show integrity in every respect ("intención, sabiduría y limpieza", 516) and be incorruptible, "sujetos dignísimos de toda recomendación, por el celo en la justicia, por la asistencia en las causas, por la entereza en el sentenciar" (516). With expertise and knowledge, they decide cases of greatest importance: "Determínanse en sus salas casos gravísimos, en rentas cuantiosos, en dignidad

16 The amalgamation of politics and religion can also be seen, for example, in the fact that Christ's obedience to his Father is interpreted in the political sense as the virtue of the subjects in relation to the King, for the benefit of the res publica (613).

17 For more on mirrors for princes during the Siglo de Oro see García Fernández.

18 Unfortunately, the complex context of Machiavellianism in Spain cannot be discussed here.

19 See also the corresponding chapter in Plaza universal: Discurso V: "De los Doctores de Leyes, o Jurisconsultos." 
sublimes, sin que alguno pueda asegurar la sentencia en más que su derecho" (516). As guarantors of the welfare of the res publica, he compares them to the "antiguos senadores de Roma, los verdaderos padres de la patria" (516). God-fearing ("temeroso de Dios", 515), they are to strive for the middle course between "flojedad y blandura" (515) on the one hand; "rigor" (519) and "severidad atroz y endurecida" (515) on the other hand, and at the same time they are obliged to the people and to justice: "La equidad del varón ha de consistir en amar a los hombres por la justicia; no posponer la justicia por los hombres" (515). From this ideal profile he discriminates the lower ranks of the judicial administration, characterizing them in accordance with the time's typical scolding of jurists as uneducated, incompetent, and corrupt, as well as young judges, who are marked by a particular arrogance, toughness and mercilessness, so that their term of service must be kept to a minimum: ${ }^{20}$

No hay furia tan tremenda como un juez primerizo, uno que desde el mendigado estudio se trasladó a la vanagloria del mando, a la ociosidad del gobierno, donde anhela por las bolsas de todos, donde muere por sembrar fuego en su distrito, desnudo de piedad, de consideración, sin Dios, sin ley ni miedo, mientras duran los tres años de su alcaldía o tenientazgo. (517)

To reinforce this stark portrait, the Doctor describes a case that he had witnessed shortly before. It involves a nocturnal house search with the aim of proving that an unsuspecting tailor had an adulterous relationship three years prior to his wife's death. The anecdote not only serves as evidence for the inhumane procedure of inexperienced judges, but the outrageous accusation involves casuistry regarding love and marriage. ${ }^{21}$ Comparable to a confessor, the representative of the law himself uses a casuistical questioning technique

20 In connection with questions of administration and legal practice, the Doctor is of the opinion that important legal positions should not be filled by persons of short stature, as they do not exude authority; to substantiate this, he refers to a precedent that is said to have occurred under the reign of Philip II (524-525).

21 Cf. Del Río Parra; for the following example particularly pages 154-155. An awareness of the corresponding categories of guilt and innocence is also evident in the autobiographical account of a picaresque innkeeper, who, after the victory of the "apetito" over the "razón", once again seeks out his casual lover, "aunque pecadora, hembra de nobles respetos", with the ostensible intention of marrying her one day, by that calming his conscience, since he thereby almost fulfills the excusable factual situation of the "matrimonio secreto": "Tenía yo propósito de volver aquel lecho, entonces sentina de maldades, en lo porvenir lícito y conyugal, como dicen los polidos, y así, no me desasosegaba mucho la conciencia" (559). 
to elicit the desired confession from the accused. This corresponds (with the exception of the last point) to the procedure described by Fernández Cano (492) - Descripción del caso, Cuestiones sobre el caso, Resolución de cuestiones:

Llegó una noche a casa de un sastre un teniente de cierta villa. Los galfarrones que le acompañaban comenzaron a derribar las puertas con furia de golpes. Levantose el hombre soñoliento, y preguntando quién llamaba a tal hora (que era casi la de las doce), respondieron abriese a la justicia. Bajó desnudo y turbado, y subiendo el tal ministro hasta su cama, halló en ella a su mujer y a una niña de cuatro años, habida en cierta flaqueza. Con aquel endiosamiento que suele tener un juez mozo (que no era viejo éste), le fue haciendo preguntas, enderezadas al examen de su conciencia: qué oficio tenía, quién era aquella mujer, y si era su hija aquella criatura. Fue respondiendo a todo como convenía, y, sobre todo, confesó ser padre de la muchacha. Díjosele si era también hija de su mujer; declaró que de otra persona, difunta tres años había. Esto bastó para decirle que se vistiese y para enviarle a la cárcel con título de amancebado con la fallecida. Por ser tan tarde, no hicieron más que meterle dentro y dejarle a su albedrío. $(517-518)$

The unfortunate defendant has to spend the night in jail, where the torture rack of another victim of justice serves as a place to sleep. However, the Doctor does not speak and act exclusively as a representative of the law and the legal system, but also as a defendant. His life story contains some picaresque episodes in which he is - rightly or wrongly - persecuted by Justice, allowing the reader to perceive the judicial system from two different perspectives. When the protagonist is accused of a homicide, a merciful person visits him in prison and questions him in a way similar to the casuistical manner in which the examining magistrate questions the tailor. Based on the practice of the examination of conscience, the two lead a kind of confessional dialogue, which in the midst of "culpas," through "perturbación," "tribulación" and "confusión" is intended to lead to the truth, whereby in the present case it is not the guilt but rather the innocence of the wrongfully accused that comes to light:

DOCTOR. Entre los que acompañaron al corregidor se halló uno del lugar, que me conocía. Lastimóle mi prisión; mas como era el caso de voz tan importante, no tuvo ánimo para decirme una palabra ni para interceder con el juez por ningún camino. Quiso, con todo, cumplir con la de misericordia en visitar los presos. Saludome, y fuese cortésmente compadeciendo de mi infortunio. Luego procuró tocar con la mano la que sirve 
por mil testigos: la conciencia. ¿Siente vuestra merced (me dijo) haber cometido cosa por donde le hayan traído aquí justamente? Respondí: No, por cierto; que, aunque impaciente y mal sufrido, ni he dado ni me han dado ocasión de pendenciar ni herir. jBien cuadra eso (prosiguió) con el título de su prisión! Pues sepa que ha procedido de haber un ventor denunciado que mató a un hombre en la Corte. Es mentira (repliqué); mas quizá Dios permite padezca mi ánimo esta perturbación por otras culpas; y así, en ella no perderé sufrimiento y paciencia. Huélgome, con todo, de saber nazca semejante tribulación de esa voz, por haberla de hacer presto mentirosa la verdad. Aunque aflige, no come este lugar a los hombres; haranse las diligencias para salir dél con brevedad. En tanto, quisiera saber quién aplicó a mi inocencia este testimonio. Un arriero (respondió enternecido el oyente) fue quien, al pasar por la plaza, lo dijo al corregidor. (538)

In the course of his adventurous escape through Andalusia, the Doctor not only makes acquaintance with the power of law. In Granada he also witnesses a tragic love story centering on Jacinta, whose name should go down in history as an example of excessive love: “ ¡Oh mujer dignísima de cualquier loor, cuán de veras amabas, cuán altamente engrandecías los triunfos de Amor! Oh nombre merecedor de ser grabado en bronces inmortales, para ejemplo de venideros siglos!" (577). As proof that "se puede morir por mucho amor," the Doctor places her story among a series of countless illustrious predecessors ("ejemplos sin número"), such as the Greek youth Eliano or the medieval "amantes de Teruel," to whom Don Luis adds the lovers Don Pedro of Aragón and Lisa (578), known from Boccaccio's Decameron $(\mathrm{x}, 7)$. The literary character of this episode is not only demonstrated by this implicit reference; the tragic "caso[.] de amor" (577) also fully displays the thematic stereotypes, narrative strategies and rhetorical procedures of the novela pastoril, including the genre's love casuistry. ${ }^{22}$

Alonso de Castillo Solórzano: Huerta de Valencia (1629)

A comparative glimpse at Alonso de Castillo Solórzano's (1584-1647) collection Huerta de Valencia (1629) demonstrates that, in contrast to El pasajero, the

22 See also "infelicísimo caso" (578) and "lamentable caso" (581); cf. Sánchez Jiménez. 
relationship between frame and embedded narratives is reversed: the novellas take center stage, while the frame story is reduced to the usual minimum for Spanish authors following Boccaccio. In this sense, the casuistically tinged debates on the moral-philosophical aspects of the respective novella plot are also missing. In the "huerta de Valencia" five bourgeois narrators gather during Easter on their estates (alcarrias). The five intradiegetic narrators who form a homosocial masculine group in the spirit of an academy are presented in hierarchical order with name, age and profession as representatives of an otium cum litteris. This entails an almost complete tableau of contemporary scientific disciplines, including medicine, law and theology as well as philosophy and history, classical philology and rhetoric.

While Don Guillén, a young, musically gifted student of "filosofía y letras", organizes the performance of a play on the fifth and last day of the 'academy', the remaining four characters, as hosts of each day, also act as narrators of the corresponding novels, to which the guests also contribute lyrical compositions. In the introductory setting, the actors are presented in order of appearance, such as the humanistically educated Don Leonardo, the protagonist of the first day:

Don Leonardo (que era el de más edad) había estudiado, hasta saber con perfección la lengua Latina, y la Rethorica, y de Historia lo bastante para hablar en cualquier conversación con seguridad de ser bien oído, y no censurado. Hacía versos con cuidado, no con afectación.

Huerta, Introduction, s.p.

As the senior member of the group, he tells the most revealing story in terms of casuistry, "El amor por la piedad," which focuses on a young nobleman from Burgos who is used as an example to explain issues regarding the concepts of guilt and innocence. He is wrongly accused of the abuse of a noblewoman and the murder of a stranger, both representing cases of great moral significance. The second day is hosted by the physician and philosopher Doctor Eusebio, who in his spare time honors the Muses: "También daba tal vez feudo a las Musas en los ratos que descansaba de sus estudios" (Huerta, Introducción, s.p.). The novella he presents, "El soberbio castigado," is a rather bold and simple example from the realm of politics, contrasting a righteous counselor and a morally dubious "privado" who, due to uncontrolled emotions (here more envy than wrath), becomes a traitor and is finally executed as a cautionary example. This is followed by the story of the young theologian Laurencio, who, with "El defensor contra sí", presents a highly dramatic crime story about love and honor, which raises a whole series of casuistical problems but ends on a happy note with an anagnorisis between father and son. The last novella is presented 
by the host of the fourth day, the "letrado" or lawyer Hortensio, who is characterized as follows:

Micer Hortensio era Jurista, y el más consumado sujeto en aquella ciencia, profesada de muchos, y bien usada de pocos, [...]. Era mozo este prudente Letrado, y en las vacaciones de su estudiosa y continua ocupación imprecaba tal vez al Délfico Planeta auxiliador de la poética congregación del Parnaso.

Huerta, Introduction, s.p.

His story "La duquesa de Mantua" is a novela cortesana (cf. Palomo) with both amorous and political plot elements, in which numerous characteristic motifs of literary casuistry and its associated moralistic reflection come together (cf. Kallendorf 2004): the challenge posed by coincidences, misunderstandings and twists and turns of destiny, the unknown or concealed identity, the typical baroque dialectic of engaño and desengaño, the conflict between love and social hierarchy, and the significance of jealousy for igniting passion in various love-triangle scenarios.

As narratives texts of a fictional genre, which shows close parallels to the comedia, the novellas of the Huerta frequently present elements which Kallendorf (2007) considers to be indicators of casuistical procedures, such as the dramatic monologue in moments of decision, the dramatization of typical cases of conscience with the corresponding vocabulary of moral confusion, as well as questions of guilt and inextricable situations of double bind. Such a situation of conflict in the form of a "choice between two viable but mutually exclusive options" (Kallendorf 2007:347) is at the center of the novella "El amor por la piedad." After courting and promising to marry Leonarda, the protagonist Fernando arrives at her house for their first nocturnal meeting. However, Leonarda's maid had mistakenly ("por yerro", 64) allowed another man into the house, who decides to take advantage of the situation ("gozar la ocasión", 64). Fernando becomes aware of the prior presence of an unknown rival when, during the course of the same night, he shares the bed with his lover, but Leonarda does not realize that she has been deceived. The protagonist now faces the almost hopeless choice between revealing to his lover that she has been seriously misled and that her honor has been violated - without being able to name the perpetrator - or remaining at her side as the betrayed fiancée. When Leonarda demands marriage and her cousin tries to take revenge, Fernando flees from Burgos to Valladolid, where he falls in love with another lady, named Estefanía. She stands by him when he is wrongly accused of murder, again due to a misunderstanding, and becomes his official lover as soon as the judicial error is resolved in his favor. The situation escalates once again when Leonarda 
and Estefanía meet as rivals in Madrid. This time, a clergyman acts as a Deus ex machina, being able to resolve the entangled case after having taken the confession of a dying man who admitted to Leonarda's abuse. In the categories of clerical casuistry based on Aristotle, this crime is a deliberate act ("voluntaria"), but on the part of the woman it is an act not deliberately committed, due to ignorance ("no voluntaria", "por ignorancia"). ${ }^{23}$ After the truth has come to light through confession, the solution of an individual "caso de conciencia" opens the path for a happy ending with a double wedding.

The protagonist of the novella "La duquesa de Mantua," told by the lawyer Eusebio, is an enigmatic young man who almost kills a duchess while hunting, whereupon the two freeze in "suspension" (203), marking the beginning of a complicated love story. Already the contradictory social signals conveyed by his clothes - a peasant cape over richly embroidered trousers - spark curiosity and "sospecha" (209) and point to a "secreto" (216). The figure of the "forastero" (208) is in this respect an "enigma" (204), which is not resolved even by his alleged life story; he remains "Fabio el encubierto" $(237,238)$. Thus the casuistical tension between (dis)simulation and its revelation, i.e. between engaño and desengaño, in conjunction with the search for the true identity, becomes the novella's leitmotif. Only at the end, through the adoptive brother's account and the public anagnorisis between father and son, it is revealed that Fabio is actually Rugero, the Duke of Ferrara's illegitimate son. Despite various indications of his prominent origin, such as his mastery of rhetoric, poetry and singing, his politeness and gallantry, his sporting and military excellence, in which the performative character of subjectivity is also manifested, ${ }^{24}$ the truth remains unknown to him until that moment.

Through the final desengaño regarding the protagonist's social identity, the love story can still have a happy ending. From the first moment Fabio had fallen in love with the duchess, "un imposible" (207) because of their social differences, he undergoes various trials and tribulations in the hope of gaining more "dignidad" (237). For both protagonists, the hierarchical divide leads to an amalgamation of social hierarchy, politics, and affects, giving rise to numerous moments of casuistical self-reflection. At first, the duchess grants him her favor only as a ruler, appointing the talented poet and singer as her court musician. This is a deeply hurtful insult to the mysterious stranger and lover, which makes him fall ill (230 s.). The topos of the "amor hereos" (cf. 224) is further exacerbated by the social divide and the despair over the fact that "su

\footnotetext{
23 Cf. Kallendorf 2004: 35 o with reference to Francisco Cascales: Tablas poéticas (1617).

24 Cf. Childers 319: "The quintessentially Baroque problematic of the performative nature of the self."
} 
desigualdad" (224) drives him almost insane ("tener por loco", 224). Therefore, he leaves the court of Mantua as a means of protecting himself and, through his absence, luring his beloved out of her reservations. In this peripheral position he finds out about a conspiracy by the Duke of Modena, who wants to kidnap the Duchess of Mantua for rejecting his love. Fabio wants to thwart the conspiracy against his beloved and, through his reflections ("considerando lo que avía de hazer en este caso", 242), he weighs the various options for action with their respective political and private implications in order to develop a promising "estratagema" in the face of the "duda", presenting a prime example of casuistical reflection upon one's own actions and their possible consequences, effectively "micromanaging their moral decisions" (Childers 325). His plan ("su traça", 245) works: the kidnapping of Duchess Camila is prevented, the traitor is executed, and the equally disappointed and angry admirer is put out of action and morally condemned by Camila's dialogue, since he wanted to gain her love by force (253).

By this point, the duchess's feelings for Fabio have changed as a result of the interplay of various emotional and rational factors that are characteristic of love casuistry. Her jealousy towards her lady-in-waiting, whose feelings for Fabio are only too obvious $(224 ; 231)$, her own claim to possession of the gallant stranger (238), coupled with remorse, having offended him by his appointment as court musician; and the regret over his absence (235) generate ambivalences and inner conflicts (227), which Camila tries to weigh rationally, but which nevertheless drive her into melancholy (239). Only the revelation of Fabio's true identity establishes equality of rank between the lovers and thus ends the conflicts between passion and class consciousness. With her happiness in love, Camila proves to be both a strong and mild ruler, since she will pardon the Duke of Mantua - after the conspiracy, his temporary imprisonment and a military campaign - marrying him to the illegitimate daughter of the Duke of Ferrara.

\section{Conclusion}

A summarizing comparison of both texts with regard to the narrative use of casuistry allows to conclude that the lawyer Cristóbal Suárez de Figueroa presents a strongly pragmatic miscelánea in dialogue form interspersed with stories of variable length. In addition to the extensive (pseudo)autobiographical narratives, there are mainly concise anecdotal exempla, which often serve as moral doctrine or illustrative argumentation. Although Suárez de Figueroa draws on the old concepts of exemplum and aphorism, he tells mainly 
contemporaneous cases from Habsburg Spain, while ancient exempla are only quoted as an element of encyclopedic erudition, probably assuming that they are familiar to the educated reader. By referring to "ejemplo" and "sentencia" in his definition of the novella, he proves to be conservative, using what Karlheinz Stierle called genre molds $(581-595))^{25}$ The fact that El pasajero is dominated by exemplary narrative is probably owing to the professional and epistemological background of the Letrado-author and his dominant narrative figures the lawyer and the theologian, each of which is associated with their specific use of exempla and case.

Castillo Solórzano's Huerta de Valencia, on the other hand, is clearly a collection of novellas in the modern sense, following Boccaccio's example. Fictionality allows the triumph of "contingency" (Stierle 582) through the work of "literary coincidence" (Köhler 1973) and a concatenation of complex cases of conscience. The extraordinary entanglements of these novellas make it clear that fiction is in no way inferior to the "outrageous and improbable" cases discussed in the summae (Childers 323), thus adding even more opportunities to see casuistry "as a totalizing discourse that attempts an exhaustive treatment of all possible moral situations" (Childers 325). Author, characters and recipients refer to casuistical patterns of thought that are used independently of specific professional practice. The narrators are academically educated citizens assigned to certain professional groups which are, however, irrelevant for the subject matter and argumentation of the respective novels. The Latin scholar, for example, tells an entanglement of guilt and innocence, while the lawyer tells a courtly love story. The ultimate goal of both novellas, however, is the search for truth beyond "apariencias", "disimulación" and "engaño." The social spectrum of narrative figures and actors proves not least of all that "a probabilistic casuistry was the most adaptable to different professions, social classes, and political circumstances" (Childers 318 ). In the novella "emancipated' from the exemplum, it is irrelevant whether a lawyer or a theologian narrates a complex fictional case - all of them testify equally to casuistry as a mental habitus. ${ }^{26}$

25 A different historical perspective, from Boccaccio to Chaucer, is offered by Jan Söffner (292), who - despite decisive differences - states that in both cases the staging is "different and competing hermeneutics", "which ensure that his casuistry does not lead to general theorems". To what extent this finding can also be applied to the authors and texts on which this study is based would have to be examined in light of the Counter-Reformation and Baroque periods.

26 At this point I would like to thank Ulrike Becker for her important suggestions and advice and Álvaro Arango Vallejo for the translation of this essay into English. 


\section{Works Cited}

Albert, Mechthild. "Letrados y literatos en la novelística áurea - El pasajero de Cristóbal Suárez de Figueroa." La autoridad de los saberes: El letrado. dir. Christoph Strosetzki, coord. Blanca Santos de la Morena, Hipogrifo 9.2, 2021: 149-161.

Becker, Ulrike. "Saberes y género narrativo en La constante Amarilis de Cristóbal Suárez de Figueroa." Saberes (in)útiles: el enciclopedismo literario áureo entre acumulación y aplicación. Eds. Mechthild Albert and Ulrike Becker. Madrid/Frankfurt am Main: Iberoamericana/Vervuert (Biblioteca Áurea Hispánica), 2016: 181-200.

Bradbury, Jonathan. The Miscellany of the Spanish Golden Age: a Literature of Fragments. London/New York: Routledge, 2017.

Chauchadis, Claude. "Libro y leyes del duelo en el Siglo de Oro." Criticón 39 (1987): 77-113.

Chevalier, Maxime. Cuentecillos tradicionales en la España del Siglo de Oro. Madrid: Gredos, 1975 .

Childers, William. "Hispanic Casuistry Studies: Room to Grow." Hispanic Review 79.2 (2011): 317-326.

Del Río Parra, Elena. "Sobre el alma: matrimonio, confesión y casuística en torno a $E l$ Burlador de Sevilla." Revista de literatura 68. 135 (2006): 151-171.

Fernández Cano, Antonio. "La casuística: Un ensayo histórico-metodológico en busca de los antecedentes del estudio de caso." Arbor CLXXI.675 (marzo 2002):489-511.

García Fernández, Eduardo. El discurso sobre la virtud política en los espejos de príncipes de los Austrias. Valentía y templanza en la teoría política entre el Renacimiento y el Barroco. Universidad de León, PhD dissertation, 2019, https://buleria.unileon .es/bitstream/handle/10612/11599/Teis\%2oEduardo\%2oFern\%C $\%$ \%Andez\%2o Garc\% $\%$ \%ADa.pdf?sequence $=1$ \& isAllowed $=y$ (Accessed 31.08.2020).

Jalón, Mauricio. “El 'orden de las ciencias' en el siglo XVI y la Plaza Universal." Península. Revista de Estudios Ibéricos 5 (2008): 65-82.

Kallendorf, Hilaire. “¿Qué he de hacer”? The comedia as Casuistry.” Romanic Review, 95.3 (2004): 374-359.

Kallendorf, Hilaire. Conscience on Stage: The Comedia as Casuistry in Early Modern Spain. Toronto: University of Toronto Press, 2007.

Köhler, Erich. Der literarische Zufall, das Mögliche und die Notwendigkeit. München: Fink, 1973 .

Londoño, Marcela. "El pecado de superstición en los confesionarios modernos." Pecados profesionales en el Renacimiento. Eds. Emilio Blanco and Mechthild Albert. Wien/Berlin/New York: Peter Lang, 2021 (2022: 97-116).

Moos, Peter von. Geschichte als Topik. Das rhetorische Exemplum von der Antike zur Neuzeit und die historiae im Policraticus'Johanns von Salisbury. Hildesheim/Zürich/ New York: Georg Olms, 1988. 
Palomo, Pilar. La novela cortesana. Forma y estructura. Madrid: Planeta, 1976.

Pelorson, Jean-Marc. Les Letrados - juristes castillans sous Philippe III. Recherches sur leur place dans la société, la culture et l'état. Poitiers: Pelorson, 1980.

Rao, Cesare. Invettive, Orationi, et Discorsi. Appresso Damiano Zenaro, 1587, https:// reader.digitale-sammlungen.de//de/fsi/object/display/bsb11216694_oooo5.html (Accessed: 31.08.2020).

Romero-Díaz, Nieves. Nueva nobleza, nueva novela: reescribiendo la cultura urbana del barroco. Newark, DE: Juan de la Cuesta, 2002.

Sánchez Jiménez, Antonio. "Los casos de conciencia en la novela pastoril del Siglo de Oro: casuismo y probabilismo en la Arcadia (1598) de Lope de Vega." Revista de literatura 76.151 (2014): 79-100.

Söffner, Jan. "Die Kunst, Novellen in die Welt zu setzen. Zur Fiktionalität in Boccaccios Decameron und Chaucers Canterbury Tales." Giovanni Boccaccio in Europa. Studien zu seiner Rezeption in Spätmittelalter und Früher Neuzeit. Eds. Achim Aurnhammer and Rainer Stillers. Berlin/Boston: De Gruyter, 2014: 277-294.

Stierle, Karlheinz. "Three Moments in the Crisis of Exemplarity: Boccaccio-Petrarch, Montaigne, and Cervantes." Journal of the History of Ideas 59.4 (1998): 581-595.

Suárez de Figueroa, Cristóbal. El pasajero, Ed. Enrique Suárez Figaredo. Lemir 22 (2018): 355-648. https://parnaseo.uv.es/Lemir/Revista/Revista22/Textos/4_El_Pasajero.pdf (Accessed: 03.09.2020).

Suárez de Figueroa, Cristóbal. La constante Amarilis. Valencia, $16 \circ 9$.

Suárez de Figueroa, Cristóbal. Plaza universal de todas ciencias y artes. Parte traducida de Toscano, y parte compuesta por el Doctor Cristóbal Suárez de Figueroa. Ed. Enrique Suárez Figaredo, 2004. http://users.ipfw.edu/jehle/CERVANTE/othertxts/ Suarez_Figaredo_PlazaUniversal.pdf (Accessed: 29.o9.2020).

Timoneda, Joan. El sobremesa y alivio de caminantes. Zaragoza/Medina del Campo, 1563. 


\title{
Opinion, Idolatry, and Indigenous Consciousness: Bartolomé de las Casas' Approach to Human Sacrifice
}

\author{
José Cárdenas Bunsen
}

\begin{abstract}
This article addresses the criteria by which Las Casas conceptualized indigenous beliefs in his Apologética historia sumaria. It maintains that the theological and juridical notion of 'opinion' undergirds Las Casas' conceptualization of religious phenomena among native peoples. Las Casas argues that human sacrifice emanates from a search for the true god within the limits of human reason, is protected with all legal considerations granted to formal opinions held in good faith and does not provide grounds to justify colonial intervention.
\end{abstract}

\section{Keywords}

Human sacrifice - idolatry - colonialism - theology and law - opinion and belief

Framed within the imperial commitment to the conversion of the native peoples, early writings about the Americas charted indigenous customs and practices. Missionaries penned accounts of native religious beliefs throughout the continent; in so doing, they preserved a wealth of information related to the multifaceted forms of worship, sacrifices, and offerings. Bartolomé de Las Casas' Apologética Historia Sumaria (1527-156o) stands out among these writings for its far-reaching scope and, more importantly, for its careful conceptualization of religious phenomena. During the long years of its composition, Las Casas (1484-1566) incorporated information he collected during his travels to Hispaniola, Cuba and Mexico, and he also drew from the missionary works, among others, by Toribio de Benavente Motolinía ( $† 1568)$ on the complex religion of ancient Mexico, and his fellow Dominican Domingo de Santo Tomás (1499-1570) on the religious landscape of Peru (Silva 344-347). Las Casas did not limit his work to a comprehensive survey built on these sources; rather he created a framework, absent in his sources, to present his vast information as he laid the groundwork for a systematic interpretation of native beliefs. 
This study addresses the criteria by which Las Casas organized the religious information in his Apologética Historia Sumaria. It intends to complement recent scholarship that addresses the issue of human sacrifice in Las Casas' thought from a legal and anthropological point of view but without an identification of the criteria on which Las Casas supported his views on religion (Carman 285-291; Lantigua 2019: 285-309). This essay maintains that Las Casas articulated his views on native beliefs based on the notion of opinion, a theological and juridical category that refers to a state of knowledge superior to ignorance and doubt, but inferior to certainty. A key feature of this concept is its ability to be changed, for there is always the possibility to persuade someone of the value and weight of a different, even contrary, opinion from the one originally held. In the Aristotelian and scholastic tradition in which Las Casas operated, the formation of an opinion closely relates to the proper functioning of the human body, whose external and internal senses affect perception, the imagination, and the rise of ideas. From a theological point of view, opinions shape religious beliefs, for the act of believing presupposes a strong, already formed, opinion about the sacred. Thus, opinion is the elementary component of idolatry, which Las Casas considers to be a universal natural-law phenomenon that inclines individuals to embark on a quest for a maker of the universe within the limits of natural reason and independently from Christian revelation.

Opinion underlies Las Casas' presentation of native beliefs in his long narrative of the development of religious opinions region by region and case by case without disregarding their natural-law basis and the natural and supernatural forces that distort the quest of natural reason for the divine. Human sacrifice puts Las Casas' theoretical approach to the test. According to the Bishop of Chiapas, the practice appears as a development of the natural-law tendency of presenting offerings of the most esteemed gifts to either the false or the true God - that is, either to the deity conceived by natural reason alone or to the Christian God. Since true religion transcends the natural capabilities of reason, people committed to their opinion of the identity of their god act motivated by a conscience that is guided by natural law, even if it is erroneous from a Christian point of view. Such acts of the conscience would absolve them from punishment for violating natural law, which a canonist might argue was deserved. But human sacrifice also grew out of the opinions that the demons and their priestly caste spread, by which they convinced their followers that their gods demanded human life in exchange for their protection. Despite their compliance - Las Casas explains - people acceded to these demands with fear and sacrificed lives unwillingly: "los indios que hacían y hoy hacen sacrificios de hombres, no era ni es de voluntad, sino por el miedo grande que tienen al demonio" (Las Casas, Apologética Historia I: 424). 
This characterization of human sacrifice in the Americas contains Las Casas' contribution to the history of indigenous consciousness, for his theorization on opinion provided a coherent explanation of indigenous religions, created a framework to reflect the intellectual activity of native peoples in forming their beliefs, and furnished a legal argument to refute the charge that human sacrifice violated natural law and justified Spanish conquest.

I present my arguments in support of these hypotheses in two sections. The first section addresses the status of opinion in the scholastic tradition and explores ideas about the formation of opinions and its links to the functioning of the human body. The second part will focus on Las Casas' systematization of indigenous beliefs and the particular case of human sacrifice.

\section{Las Casas' Premises on Opinion, Idolatry and the Functioning of the Body}

At the center of Las Casas' reasoning on native religions lies the notion of opinion. At the time when Las Casas addressed Amerindian matters, opinion had been the subject of a long development in dialectical thinking in which it was established as a level of knowledge relevant to moral and theological reasoning.

In medieval epistemology, the attainment of a certain opinion was held to be the result of reflection. This conceptual result ended the mind's state of suspense as it rose above lower states of knowledge such as ignorance, doubt, and suspicion. Opinion, though, did not reach the highest level of certainty, given that it retained a degree of doubt (Albertus Magnus 2: 150-151). ${ }^{1}$ In the terms of Albert the Great (ca. 1206-1280), 'opinable' was a notion distinct from 'knowable.' The latter referred to universal conclusions to which the mind arrived based on universal premises through necessary, non-contingent reasoning; while the former relied, instead, on necessarily accepted premises that would operate as the basis to support the process leading to the formation of an opinion (Albertus Magnus 2: 149). Consequently, opinion results from an argumentative chain that proceeds not on necessary, but instead on contingent premises situated above mere conjectures and aspiring to a conclusion considered to be the likeliest in the mist of contingencies (Deman 26o, 265) ${ }^{2}$

1 For a thorough discussion about the category of opinion, see the study of Deman and the entry 'opinion' in Ferraris' compilation of canon law under "opinio."

2 The premises of this approach involve the assumption that both the functioning of nature and human actions are intrinsically contingent, they do not act always in the same predictable way (Aquinas, Summa Sacra 1.2.84.1). 
Thomas Aquinas (ca. 1225-1274) captured the nature of opinion in his definition: "Opinio significat actum intellectum nostri qui fertur in unam partem contradictionis cum formidine alterius" ("Opinion expresses an act of our intellect which makes an assertion on one part of a contradiction with fear of the other part," Aquinas, Summa Sacra I.79.9). In addition to the recognition of the intellectual activity required to arrive at an opinion, Aquinas also anticipates the necessity of a decision to assert one conclusion over another in the face of two seemingly valid, albeit contradictory, opinions. In fact, every opinion bears an inherent uncertainty that implies that the evidence on which it is based could have a different explanation; in other words, another opinion based on a firmer and likelier basis could replace a prior one. Therefore, opinion demands a certain acceptance, akin to faith, of certain propositions endowed with a degree of likelihood (Albertus Magnus 2: 150).

For these reasons, opinion was associated with the concept of the probable - "probabilis" in medieval terminology - identified with the judgement that all or the majority or the wise commended (Aristotle, Topica 10ob; Albertus Magnus 2: 267). The probable, also conceived as a quality that makes a particular opinion or judgment worthy of voluntary approval, was the matter out of which opinion was formed (Richard 94). Las Casas insistently referred to Amerindian beliefs as opinions. The Inca, for instance, greatly admired their wise rulers and thus "vinieron en opinión que aquellos eran más que hombres" (Las Casas, Apologética Historia I:434). The Totonaca people practiced a vocal confession that by itself demonstrated "la fe o opinión que tenían del Dios grande y de los otros dioses." Also, among the Aztecs, the high priest elevated the censer toward the sun "teniendo por opinión que del cielo y por mandado del sol habían descendido los otros dioses" (Las Casas, Apologética Historia II: 147; II: 190, respectively).

Las Casas' apparatus in his Apologética Historia points to the epistemology of opinion reconstructed above as its conceptual grounds (Las Casas, Apologética Historia I: 57, 79-86). For Las Casas, opinion is closely related to faith. Albert the Great explained their epistemological link in his classification of the different states of the mind in its confrontation with dialectical problems. He identified four different situations in which reason finds itself in its quest for knowledge:

dubitatio est indeterminatus motus rationis super partes contradictionis sine ratiocinatione consensum inclinante. Ambiguum autem est, quando ambit utramque partem per rationes aequipotentes. Opinio, autem, quando non confirmato quidem consensu complectitur alteram. Fides vero quando fortificatur in alteram sine fundatione in eadem scientia, aut quando fundatur per demonstrationem. 
doubt is an undetermined movement of reason over the parts of a contradiction without ratiocination inclining to a consensus. Ambiguity happens when [the mind] encircles both parts through equipotent reasons. Opinion, on the other hand, occurs when it embraces one part through an unconfirmed consensus, and faith when it is fortified in one part without foundation either in knowledge itself or through a demonstration.

ALBERTUS MAgNUS 6:134

It follows from this classification that opinion and faith represent similar states in which the movement of reason has already formed a certain judgment of a certain caliber, despite the fact that neither of the two represents an absolute certainty. However, faith reaches its conclusion with no demonstration, for it demands a leap of the will to attain the mind's assent. Because of its basis in likelihood, opinion is the type of intellectual judgment best suited to the making of moral decisions on what to avoid and what to choose rightfully.

Las Casas fully accepted this epistemological tradition and embraced it throughout his writings. His adoption of these premises is particularly clear when Las Casas dismantled the arguments of the defenders of Indian slavery. Las Casas fiercely opposed these enslavement procedures and undertook an intellectual rebuttal in which he laid out the legal principles that made Indian slavery illegitimate. Arguing that Spaniards in the colonies could not ignore the immorality of the practice, Las Casas quoted the well-known opinion of the mendicant orders who preached against this type of slavery and maintained that Spaniards had a moral obligation to follow the friars' opinion. In this context, he equated the opinion of the friars with the probable opinion of the learned wise men, as Aristotelian Topica conceptualized it:

ésta [la opinión de los religiosos sobre los indios esclavos] es la que se llama probable opinión, conviene a saber, cuando los más sabios y más experimentados, y más honestos y temerosos de Dios, y que menos interese pretenden, o la mayor parte dellos afirman y tienen o les parece una cosa ser verdad dañosa o peligrosa, como dice el Filósofo en el $1^{\circ}$ de los Tópicos; a los cuales son los hombres, al menos los que no tienen muchas letras, y comúnmente todos los seglares, obligados a creer y a seguir en las dubdas, señalada e infaliblemente si siguen y aconsejan aquello en lo cual no hay peligro alguno, o si lo hay es menor y de menos riesgo y daño que lo otro de que se duda; y si acaso yerran llámase probable error, y son los que los siguen escusados; y los que no los siguen, arrimándose antes a su parecer, yerran e ignoran improbablemente, y todo daño que de allí se sigue les es imputado. 
In addition, Las Casas inscribed the friars' opinion within the framework of the probable and further explained the associated concepts. In particular, he points to the notion of "probable error." This concept complements the opinio probabilis mentioned in the passage in the sense that opinions, as shown above, contain an intrinsic margin of error because of their reliance on likely propositions, which are contingent and able to be replaced with more solid ones. If an opinion induced someone to act in a certain way and it turned out to be an incorrect opinion, the individual who had followed it would be morally and even legally excused of any guilt, for he had committed an error based on an opinion he considered to be correct.

Beyond the legal domain, opinion also bears theological implications, which originate from the resemblance of opinion and faith as intellectual states to which the mind arrives through similar reflective activities. In exploring this connection, Las Casas relied on the theology of Guillaume d'Auvergne (ca. 1180-1249), specifically on his polemical treatise De fide et legibus devoted to discerning the nature of faith and the pillars of Christianity. The Bishop of Paris recognized faith to be the basis of religion, but he acknowledged that faith demands people to believe in many unlikely and non-evident principles; in this approach, belief presupposes a desire to choose it (Auvergne, Part 1, Chapter 1, section C). Because of this condition, belief is an intellectual operation able to be contested; it is also very different from knowledge, which is established on demonstrably necessary premises. In Auvergne's views, belief is akin to a strong opinion, "Comprehendimus autem opinari in eo quod est credere quoniam credere quoddam opinari est. Credere enim est vehementer opinari" (Thus, we comprehend to opine in that which pertains to belief, because to believe is a certain kind of opining; for to believe is to opine vehemently, Auvergne, Part 1, Chapter 1, Section D). ${ }^{3}$ Auvergne's conceptualization of opinion undergirds his reflection on natural theology; he finds the root of idolatry in humanity's original sin which corrupted the human desire for and tendency to believe the supreme truth - and he identifies the supreme truth with God. Idolatry also directed that natural desire towards "other truths," which are weak and vile in nature; but human desire misidentified them with divine truth. On the grounds of this natural appetite for the supreme truth, Auvergne declared the universality of idolatry:

Servitus divina sive cultus divinus sive verus sive erroneous universalis est: hoc est apud omnes nationes a perpetuus pene enim nullo tempore

3 It is relevant to note that opinions could have different calibers and degrees of acceptance. It could be an individual opinion or an opinion commonly shared by many; it also could be felt reflexively or vehemently (Gardeil 474-482). 
defuit ydolatria vel verus dei cultus ex quo homines multiplicari ceperunt et adhuc ydolatria apud omnes gentes est vel in capitalibus suis vel in ramis vel in reliquis adeo autem adherens: ut nec igne nec gladio vel alia via adhuc exterminari possit.

Divine service or divine worship, either true or erroneous, is universal: it exists among all nations perpetually, for idolatry or true divine worship was almost never absent since men began to multiply. And hitherto idolatry exists among all nations, and it is so firmly fixed to their headbands or branches or relics that it could not be exterminated either by fire or the sword or in any other way.

AUVergne, Part 8, chap 2, Sections C

Las Casas construed his notion of idolatry based on this definition by Guillaume d'Auvergne, and from it he derived two important implications: the natural universality of idolatry and its status of being an opinion. This combination emerged in his paraphrase of Auvergne's ideas in which Las Casas described the intellectual operations that follow the natural desire to know the divine:

Deste continuo apetito, deseo, inclinación y hambre natural de nuestra potencia racional por saber verdades, y de nuestra potencia concupiscible buscar bienes en que deleitarse, y de la irascible pugnar y no dar lugar a lo contrario que lo impide, venerando el objeto de la concupiscible, necesariamente se sigue no poder ser nuestra racional potencia sin alguna opinión y creencia falsa o verdadera.

LAS CASAS, Apologética Historia I: 242 (Italics added)

The whole dialectical framework and writings of Auvergne underlie this conceptualization. Moreover, idolatry is the result of a complex intellectual process that naturally suggests concrete religious ideas, and people put them into practice in the form of worship and honors rendered to what is considered a divine being. By virtue of this quest for the divine which is ingrained in the human mind, idolatry becomes a natural, universal phenomenon:

Cuando quiera que faltó gracia y doctrina y no hobo quien guiase y enderezase los ánimos de los hombres [...] la [potencia] racional fue a parar en creencias y opiniones de diversos errores y la concupiscible en desear y deleitarse en impuras y no verdaderas bondades, y la irascible a dar la honra, obediencia y servidumbre de las criaturas que a solo Dios se debía, conviene a saber, a aquellas cosas en las cuales alguna señal o apariencia de bondad o excelencia se cognoscía, que llamamos ídolos, o a las 
cosas que representaban los ídolos, porque cualquiera bondad y alteza y nobleza que las criaturas tienen o muestran, no son sino vestigios y semejanzas del altura, excelencia, y majestad divina, y veis aquí la idolatría contraria de la latría y reverencia y culto divino que a solo Dios se debe, por el mundo introducida, porque natural cosa es a nuestra humana naturaleza humillarnos y ofrecer nuestra subjeción y hacer reverencia y dar honor a aquello que es superior a nos según nuestra estima.

LAS CASAS, Apologética Historia I: 242-243 [Cap.73]

Beyond the theological background outlined above, Las Casas was a realist: these principles must be anchored in the intellectual capacities of Amerindian peoples. In the Apologética Historia, he discussed at length the conditions for the birth and growth of people in the Indies as part of the proto-anthropological framework that Las Casas created to historicize the emergence of political prudence in the continent (Cárdenas Bunsen 247-249). The framework presents the geographical and climatic conditions for natural human generation, and Las Casas later proves that the bodies and souls of the peoples born under these conditions work properly (arguing against the ancient idea of the uninhabitable Torrid Zone). For this section of his investigation, Las Casas continues to rely on the Aristotelian legacy regarding the soul that Albert the Great and Thomas Aquinas further developed (MacCormack 225). ${ }^{4}$ In this tradition, the relation between the soul and the body, and the configuration of each, play a central role in the formation of opinions and in the mechanics of intellectual operations. Las Casas remarks on the connection between body and soul, arguing that a well-developed soul requires a well-formed body (Las Casas, Apologética Historia I: 73-80).

Las Casas embraces the premises of the Aristotelian legacy on the body according to which it works in tandem with the soul to make possible the faculties of nutrition, sensation, thought and movement. The body feels through the senses and mediates the perceptions of the soul, for knowledge and thought arise from sensible things (Aristotle, On the Soul 413b; Albertus Magnus 5: 118). The external senses' provision of sensorial information to the internal senses sets in motion complex intellectual operations (Aristotle, On the Soul 413b, 426b; Albertus Magnus 5: 303, 316-318, 328; Michaud-Quantin 69). Writing in

4 Wey Gómez (99-100) points out that Albert the Great's geographical views shaped Las Casas anticolonial considerations on the location of the Indies and their heavens and grounds. This scholar keenly contends that Las Casas's choice is a form of discussion with Pierre d'Ailly's thesis on the same matters that reinforced the colonial enterprise. In a similar manner, it is fair to add that Albert's studies on the soul and his investigation on Aristotle's Topica informed Las Casas's conclusions on these particular matters. 
his eyewitness capacity, Las Casas offers proof of the optimal functioning of the external and internal senses in the peoples of the Indies by referring to the natives' ability to stage sacred plays, their talent to paint, their intelligent learning of the liberal arts and their remarkable execution of the crafts that they have acquired, which attest to their common sense, memory, judgement, imagination and fantasy, that is, to the potency of their internal senses (Las Casas, Apologética Historia I: 213-219).

Beyond the verification of the optimal activity of body and soul, there is further connection between their functions and the generation of opinions. For Aristotle asserted that knowing, perception, and the formation of opinions are operations of the soul (Aristotle, On the Soul 411a). Specifically, two internal senses, imagination and phantasy, are necessary in order to form judgment and opinions, but these two are not the same. Opinion and judgment both imply understanding, but the first is further differentiated from the second based upon the fact that opinion demands acceptance, which requires a dose of faith to assent to a particular opinion, even when one fears that it could be false, as noted above (Albertus Magnus 5: 323-325).

There is an additional relation between phantasy and opinion, which is important in explaining why Las Casas chose the second to be the theological and legal category that sustains his account of Amerindian religious beliefs. Deliberating reason could influence phantasy, direct it, and incline its appetite according to its meditations. Thus, from the mental images already elaborated by the internal sense of phantasy, reason selects those images considered best on the basis of its opinions, and in this manner, opinion can influence phantasy and shape the appetite and desires (Albertus Magnus 5: 407-408). Therefore, opinion is deeply interconnected with the body, soul and their intellectual capacities and activities.

As an epistemological category, opinion represents the attainment of a level of knowledge that stems from probabilistic reasoning. In anchoring its generative mechanism in human abilities, opinion results from the good functioning of the external senses of the human body and their joint action with the internal senses. In this reciprocal relation, opinion influences and even shapes the mental images elicited by phantasy, which synthesizes the information that the other internal senses transmit. Therefore, opinion molds the apex of the mind's activity, and thus it becomes a potential element to be imitated at the moment when phantasy shapes the appetite and desires. Its centrality in the workings of human consciousness explains why Las Casas positioned opinion at the center of his presentation of Amerindian religion. For his protoanthropological project, the final step consisted in his effort to historicize the formation of those religious opinions throughout the Indies. 


\section{Opinion, Indigenous Consciousness and the Legal Case of Human Sacrifice}

The implications of the functioning of opinion, its kinship with the notion of belief, and its influence on human intellectual activity likely convinced Las Casas to focus on opinion as the main element in his detailed account of native customs and beliefs. The quasi-equivalence established between belief and opinion paved the way to introduce indigenous religious concepts as opinions in several instances, thus explaining key tenets of indigenous faith as concepts that reflect the rationality and interior consciousness of the people who professed them. In documenting Mexican beliefs, for instance, Las Casas explicitly refers to the high esteem in which the natives hold their gods in terms of opinions:

Cuanto a la sanctidad que por la devoción y opinión del pueblo se le recrecía, nunca jamás en ninguna gente de las erradas por la idolatría, en el mundo se vido, que más devoción, ni mayor, ni tanta opinión tuviese de sus dioses o ídolos, así creyese su santidad y por consiguiente fuese más solícita en la observancia de su religión que aquestos indios. Esto asaz puede haber sido manifiesto si se ha querido mirar en ello, por lo mucho que de los dioses y de los templos queda dicho y mucho más claro parecerá de que tratemos de los sacrificios.

LAS CASAS, Apologética Historia I: 456 (Italics added)

Las Casas gives a similar account of the pagans of the ancient world, speaking of their "uso y opinión" in religious matters in order to compare them to those of the Indies (Las Casas, Apologética Historia II: 37).

The underlying categorization of Amerindian beliefs as opinions informs his entire discussion of Amerindian religion which, in turn, composes the fifth part of the Aristotelian polity. The whole Apologética Historia intends to show that the different parts of Amerindian societies conform to the cities and polities that Aristotle's Politics describes, which demonstrates the political prudence of Amerindians (Las Casas, Apologética Historia I: 198). Despite the wide territorial extension of the Indies and the heterogeneity of native beliefs, in this section of his book Las Casas aims at organizing, explaining, and presenting the historical formation of the opinions that configured the religious landscape under consideration.

Arising from the interaction between opinion and phantasy, Amerindian religious beliefs connect with a chain of premises that Las Casas considers to be natural in human beings thanks to the action of synderesis, a natural habit 
that exists, according to Thomas Aquinas, in human reason. Synderesis permits men to access principles such as the tenets of natural law, the preservation of the self, the inclination to follow the good and avert evil (Aquinas, Summa de veritate, Materia 16, quaestio 1; Las Casas, Apologética Historia I:134-135). From synderesis also springs a universal desire to initiate a quest to know the divine. Las Casas acknowledges this tendency in his collection of religious customs from around the world:

El hombre naturalmente es inclinado y desea saber las verdades, mayormente cognoscer a Dios, por lo cual dijo Aristóteles en el principio de su Metaphísica: Omnes homines natura scire desiderant.

LAS CASAS, Apologética Historia I: 135

From this anthropological premise, the universal reach of religion ensues; idolatry gains the status of being a universal phenomenon integral to human nature for those peoples previous to - or coeval with, but outside of - Christianity, given that idolatry includes a natural-law conclusion according to which the world has a maker (Las Casas, Apologética Historia I: 240). This complex argument explains the widespread belief in the existence of a supreme being that Las Casas charts across the Indies. From the Caribbean to Guatemala, Mexico and Peru, Las Casas documents some faint knowledge of the true God naturally instilled in people which takes the appearance of a belief in a creator and lord of the world thought to be invisible in some places, despite the fact that many peoples identified him with the sun (Las Casas, Apologética Historia I: 416, 420, 428). However, the idea of God appears mixed with spurious beliefs which Las Casas attributes to various causes (Las Casas, Apologética Historia I: 428, 432). The active work of the demons spreading falsehoods to occupy the place reserved for God is to blame in the majority of cases (Las Casas, Apologética Historia I: 246). The devil counted on the assistance of his ministers whom he appoints and favors in order that they will help him spread his lies. In most places, these ministers tend to institute a priestly caste and to become a source of false opinions that target the imagination and phantasy of the natives and make them believe that good comes from the idols and false deities they promote (Las Casas, Apologética Historia I: 416-418). Las Casas repeatedly describes this pattern:

El demonio, lo primero que acostumbró al principio que quiso introducir en el mundo la idolatría, fue constituir ministros y sacerdotes della, por engaño que hacía a los más dispuestos que para ello en malicia y astucia hallaba, para que por medio de aquellos su poco a poco a todos los demás 
engañase, y cómo estos sean, por sus ficciones y prestigios que hacen, de los pueblos y gente simple venerados y acatados, y así alcanzan honra y estima y dádivas y lo que más la soberbia y cudicia les demanda, y por la predicación de la fe y doctrina cristiana todo aquello se les desbarata.

LAS CASAS, Apologética Historia I: 430

What follows from this account in the larger argument of the Apologética Historia is that these lies and deceptions through the words and deeds of these ministers persuade the native minds, and thus false opinions arise from false premises.

Writing from the position of an early modern bishop and taking Catholic tenets as the only true standard, Las Casas maintains that the basic intuition of monotheism, attainable through natural reason, blends with a wide variety of ancillary beliefs, such as the attribution of a mother and a brother to God among the natives of Hispaniola (Las Casas, Apologética Historia I: 416). Despite these errors, Las Casas insists on presenting the rationale behind those opinions that explain why and how the natives chose their gods. Some of them adopted as their deities those entities considered to be their providers of water, wind, and sun; others selected the protectors of the earth, skies, and everything else (Las Casas, Apologética Historia I: 417, 421). Some people deified their wise rulers, as occurred in some places in the Andes, where the natives reported that "veneraban a señores que habían tenido, porque los habían blanda y suavemente gobernado, y así poco a poco vinieron en opinión que aquellos eran más que hombres" (Las Casas, Apologética Historia I: 434). In discussing the case of Hispaniola, Las Casas recalls his interest in the indigenous observance of offering first fruits to their gods and his care in asking the natives who their Cemí, the local ancestral deity, was. To which they answered, "el que hace llover y hace que haya sol, y nos da los hijos y los otros bienes que deseamos" (Las Casas, Apologética Historia II: 121). Their response carried the implication that they held the rational opinion that their god was a provider. This realization led Las Casas to preach Christianity and to consider that making offerings was a universal religious behavior (Las Casas, Apologética Historia II: 121). In a similar manner, Las Casas reports that the Spaniards newly arrived to the Floridian province of Quivira conferred with King Tartaraz who, when asked whether he revered wooden idols, responded that he only worshiped the sun and the moon because his people receive food and sustenance from the sun and health from the moon. Las Casas again includes the reasons for the king's belief (Las Casas, Apologética Historia II: 126). In sum, Las Casas' account of Amerindian beliefs displays the reasons that give strength to the opinions on which each particular faith rests. In so doing, Las Casas created an analytical 
apparatus that cohered with the indigenous consciousness and that mirrored the intellectual activity of the believers with its natural-law components and the external elements that reflected their actual belief. From this perspective, his Apologética Historia is not just a collection of detailed ethnographic information, but also an effort to portray the conscious and intellectual underpinnings of natural religion as attested in the Indies.

Adhering to Aristotle's account of the role of religion in the constitution of a well-established polity, Las Casas focused first on deities, for they compose the primordial part of religious beliefs. The second part of his account addresses temples, which Las Casas remarked were consistently centrally located, generously endowed by the rulers, and industriously sustained. The third part discusses the priestly caste, about which Las Casas regretted his lack of sufficient details. Sacrifice and offerings ensued, to which he devotes considerable attention. His approach to sacrifice is not an exception to the scheme of his Apologética Historia, for the notion of opinion informs his account of sacrifice.

Las Casas realized in Hispaniola that sacrifice was a universal natural behavior. He confirmed as an eyewitness a well-established tenet of natural theology about which he had only read before (Las Casas, Apologética Historia II: 121). He defined sacrifice as an exterior recognition of what was considered the most excellent being, that is, God (Las Casas, Apologética Historia II: 33-34). The variety of sacrificial practices, the different nature of the sacrificial gifts ranging from artifacts, plants and animals to human victims, and the careful observance of the rituals prompted Las Casas to conclude that the preciousness and excellence of the gifts offered in sacrifice reflect the high esteem in which a certain people held their gods, which, in turn, attests to the complex rational steps that sustain those beliefs (Las Casas, Apologética Historia II: 167). In fact, Las Casas outlines the sequence whereby the rituals and protocols of offerings and sacrifices were established:

Por manera que sacrificios no tenían ningunos, porque como de todo el discurso que habemos traído, refiriendo los dioses, y templos y sacerdotes, y sacrificios de las gentes antiguas y destas indianas, puede colegirse, según el concepto y estimación que los hombres de Dios alcanzaron, así le tuvieron la devoción y le constituyeron los templos, y hobo el sacerdocio e inventaron y ordenaron los sacrificios, y, por consiguiente, fueron en ceremonias más o menos religiosas; de manera que, de lo primero necesariamente se siguió lo segundo y de lo segundo lo tercero y de lo tercero los sacrificios, que es lo último. 
Since they are a consequence of this rational sequence, sacrifices not only reflect the level of civilization of a certain group, but also reveal both its crystallization of natural law that demands the making of sacrifices and its freedom to determine the specific offering. This explains the wide variety and forms of sacrifices, for every polity would regulate its calendar, its rituals and the kind of sacrifices and victims (Las Casas, Apologética Historia II: 34). There is, though, a particular kind of oblation which renders human victims and from which almost no nation - including Spain - was an exception (Las Casas, Apologética Historia II: 98). ${ }^{5}$ In the Indies, the Inca and the Mexica practiced human sacrifice, but the latter stood out for being the one nation that exceeded all the rest in the scope, amount and complexity of their sacrificial rituals. With the framework that Las Casas created to approach religion, the exacting demand of human sacrifice is commensurate with the attributes that Mexicas ascribed to god through the sole guidance of reason, though he also noted some demonic menaces in the realization of this practice that made it not entirely a voluntary offering (Las Casas, Apologética Historia II: 121, 128). The Mexicas sacrificed prisoners of war in the ceremony of the new fire at the end of the calendar cycle of $5^{2}$ years; they also observed a Lenten period in which they again offered prisoners of war as victims for the common good. Prior to their sacrifice, these prisoners underwent a ritual sacralization consisting of freeing them and granting them exceptional treatment in preparation for becoming victims in honor of their idols, through which their prayers for health, prosperity and protection would be heard. Later they would cook and eat the sacralized flesh of these victims (Las Casas, Apologética Historia II: 129, 150-152). The sacrifices to Tlaloc, god of water, originated from the periodic occurrence of draughts, and - upon consultation of an oracle and the instructions of the priests - from the attempt to please the god and implore him to bring rain by offering him the precious gift of children's lives (Las Casas, Apologética Historia II: 132). Among the Totonacas, human sacrifice involved a communal dimension. Influenced by the Mexicas, Totonaca priests preached that the sun was the maker of the universe and that he would send his son to earth to renew it and to lengthen human lives. To implore the sun to make good on these promises, the community selected messengers to deliver the collective plea to free them from the burden of human sacrifice which they

5 In his vast compilation of rites and customs, Las Casas draws the reader's attention to those practices held in Spain in Pre-Christian times such as the human sacrifices offered to Mars (Las Casas, Apologética Historia II:53). It is a repeated intent, throughout his works, to establish comparisons between the Indies and Spain in several aspects of their customs and, particularly, in their similar religious history that began in infidelity and culminated in the conversion to Christianity (cf. Historia de las Indias I:16-17). 
offered as penance for their sins (Las Casas, Apologética Historia II:145-146). In the last two cases, Las Casas observes that the people did not make these sacrifices willingly but rather out of the fear mostly instilled by demons' menaces of future disasters and misfortunes, unless sacrifices be performed. This sentiment contrasts with the worship of Quetzalcoatl, for this deity rejected human sacrifice and generated an admiration and love above the other gods from the people (Las Casas, Apologética Historia I: 424-425).

Las Casas concludes his discussion of the mental activity that undergirds sacrificial belief by stating that the natives' intention in performing human sacrifices was to honor the god that they considered to be the true god (Las Casas, Apologética Historia II: 167). Natural law sanctioned the offerings and sacrifices, though there was no positive law about what the offerings should be.

The Apologética Historia's meditation on human sacrifice is the textual locus where Las Casas solidified the grounds to settle the debate in which he engaged with Juan Ginés de Sepúlveda (1494-1573) at Valladolid in $155^{\circ}$ and $1551 .^{6}$ Las Casas was aware that he had crafted a unique account of human sacrifice. In 1564, Las Casas wrote a letter to the Dominican chapter of Chiapas and Guatemala in which he acknowledged the coincidence of his opinions and those of prominent theologians of the School of Salamanca. With regards to human sacrifice, Las Casas proudly stressed his pioneering treatment of the subject: "probé muchas conclusiones que antes de mí nunca hombre las osó tocar ni escribir, e una dellas fue no ser contra ley natural seclusa omni lege positiva humana vel divina, ofrecer hombres a Dios, falso o verdadero (teniendo el falso por verdadero) en sacrificio" (Las Casas, Obras 13, 355; see Carman 278-280). In particular, his reflection on human sacrifice confirmed his profile of the fourth type of barbarians to complement the arguments he advanced in Valladolid and mustered the factual ammunition to demolish the legal and theological case for human sacrifice as justification for the Spanish war of conquest.

During the Valladolid dispute, Las Casas argued against Sepúlveda's characterization of Amerindians as outright barbarians and even natural slaves by appropriating Aquinas' analysis of the three different meanings of the word 'barbarian' according to its usage in Saint Paul's epistles and Aristotle's philosophy. Aquinas maintained that 'barbarian' refers to foreigners, to those that speak a language different from one's own, and to those with a strong corporeal makeup and lack of reason, deprived of laws and community (Aquinas, Commentaria, Ad Corinthios, lectio 2, sub si ergo nesciero). Also, Aquinas distinguished between barbarians 'simpliciter', that is, barbarians absolutely

6 The Valladolid debate was a watershed moment in the early intellectual history of the Indies. For thorough details, see Wagner and Parish 170-182 and Losada 279-306. 
and without reserve, and barbarians 'secundum quid,' that is, barbarians in a certain respect, be it nation, language, or gender (Aquinas, Commentaria, Ad Corinthios, lectio 5, sub Graecis ac barbaris). Las Casas borrowed this tripartite distinction for his intervention at Valladolid. Nonetheless, the passage of time between this debate and the conclusion of his Apologética Historia sufficed for Las Casas to add a fourth category of barbarian which he identified with infidels. This addition constitutes Las Casas' contribution to the discussion; he borrowed the old legal and theological notion of infidelity, which Aquinas had anticipated but not thoroughly developed in his commentary on the Pauline epistles. ${ }^{7}$ Las Casas then addressed the ambiguity of maintaining that human sacrifice conforms to a highly sophisticated form of natural law, while he attempted to avoid the risk of seeming to support a practice at odds with the consensus of his missionary peers. His solution took the form of a series of observations on the limits of natural reason and the necessity of Christian doctrine, noting that natural reason is able to rise to the idea of monotheism but not to that of the Trinity; and that moral, rational virtues are exceeded by the supernatural, theological virtues granted only through baptism (Las Casas, Apologética Historia II: 179-180). Biblical loci and authoritative passages of Church fathers buttressed these arguments: in particular, the Book of Wisdom's declaration that only the Holy Ghost properly orders human acts, along with Lactantius' claims that the discordance between faith and the customs of infidels reveals that they remain rude and unwise despite any knowledge of liberal disciplines. Lactantius brings up the practice of human sacrifice as proof (Las Casas, Apologética Historia II: 439). In the context of arguments developed in the Apologética Historia, the opinions that infidels reached through natural reason and crystallized through natural law lay at the core of his characterization of this type of barbarians. In Las Casas' view, Amerindian idolatry, aside from being a barbarity secundum quid, does not fall outside of natural law. Thus, he does not differentiate these infidels from other people except for their lack of Christian doctrine and their pre-baptismal status that would be remedied through conversion.

In 1527 Las Casas had planned that his Apologética Historia would be part of his Historia de las Indias. In the aftermath of the Valladolid debate, and in order to cement his defense of American Indians, he recast it in a polemical fashion and completed it between 156o and 1561 (Wagner and Parish 195-204, 287-289; Adorno 2008: 93-95). At Valladolid, Sepúlveda put forward four arguments to make the case for waging war against Amerindians: their idolatry and sins against nature, their natural barbaric condition, their cannibalism and

7 For a discussion on the status of infidels and the legal and theological implications of the concept, see Muldoon 19, 141; Lantigua 2020: 74-140; and Capéran I: 4-7, 29. 
human sacrifice, and the European goal of preaching the Christian faith (Las Casas, "Aquí se contiene" 229-231). In his own Apología, Sepúlveda further justified this war by invoking the papal power to force peoples to obey natural law to which all men are subject. He quoted many legal authorities in support of this point, among which Innocent IV's gloss on the canon Quod super his, de voto stands out (Sepúlveda 20o). Innocent IV († 1254) provided Las Casas with legal arguments to demonstrate the rightful dominion of infidels over their property and lordships; but Innocent also affirmed that the pope could exercise his temporal power to punish infidels who acted against natural law and worshiped idols (Innocent, ad c.8.X.III.34). Las Casas deemed this portion of Innocent's opinion to be a blatant error (Las Casas, Apología 124-134). In his rebuttal, which appears throughout his Latin Apologia, his controversy against Sepúlveda and his Apologética Historia, Las Casas outlined a legal argument that would prove that ignorance and probable error shielded the natives from believing that human sacrifices were against natural law. First, idolatry emanates from the natural-law search for the maker of the universe; this quest engendered particular beliefs which were juridically equivalent to a vehement opinion (Auvergne Pars 1, cap.1, D). Second, Las Casas' arguments make clear the difficulty of demonstrating to the natives that human sacrifices contradicted natural law, since reason leads to the opposite conviction according to the premises laid out in his Apología. Natural law teaches that men owe human sacrifices to the true god or even to a false deity if it is thought to be true (Las Casas, "Aquí se contiene" 399-401). In his Apologética Historia he would later contend that human sacrifice mirrored the elevated opinion that natives hold of their gods (Las Casas, Apologética Historia I: 456). Natives do not ignore the mandate to present offerings, including human victims, to god; they ignore, though, the identity of the Christian God. They followed the probable and common opinion of their rulers and wise men in religious matters. In raising this argument, Las Casas rejected Sepúlveda's narrow definition of probable opinion, which restricted the ability to hold probable opinions only to non-barbarian, political and human peoples (Las Casas, "Aquí se contiene" 321). ${ }^{8}$ Las Casas rather expanded the notion of probable opinion in order to include the religious opinions held by the wise and prudent of any nation, even if they were erroneous from a Christian perspective. His intention was to attribute to the native common opinion the same status that the communis opinio received in legal doctrine. Las Casas reiterated that the communis opinio is

8 The meaning of 'human' in this context does not convey the fixed sense of 'human race, humanity'; rather it refers to the customs and civic virtues that make a people able to selfgovernance. For a thorough discussion see Adorno 2008: 106, 115-117. 
a kind of probable opinion defined by the support of the wise who might err only from the perspective of divine law but not from the perspective of natural law. He added that "por esta manera dicen los juristas que communis opinio inducit errorem probabilem, ut in cap. único iuncta glosa de postulatione prelatorum, libro 6, ff. de iure et facti ignoratia" (Las Casas, Tratados 411). The relevant loci of civil and canon law clarified the implications of the argument. Roman civil law established that "ignorantia facti excusat sed not ignorantia iuris" (Ignorance of facts excuses, but ignorance of the law does not, Corpus iuris civilis D.22.6.1-2). In glossing the canon that Las Casas referred to, canon law makes a similar conclusion, "iuris ignorantia nec est probabilis nec excusat" (Ignorance of the law is not probable ignorance and it does not excuse, Catholic Church, c.1.1.5.in vi sub probabiliter).

It follows from these legal principles that idolaters and practitioners of human sacrifice did not ignore the natural-law mandate in presenting offerings, including human victims, to god; in fact, their synderesis searched for the true divinity, and the defense of their creed and rituals was lawful under natural law. They ignored, though, the Christian God, whose identity could not be discovered by reason alone, but only through revelation. Their rational religious conviction engendered an erroneous conscience that induced them to act in accordance with it. Their actions do not constitute sins because they proceeded erroneously only accidentally (per accidens); their intention was to honor the true God (Aquinas, Summa Sacra 1.2.19.6). From the perspective of both canon and civil law, human sacrifice and idolatry were not just cause for military interventions.

Las Casas furnished his anthropological perspectives on native beliefs on the epistemological, legal and theological basis of the notion of opinion, which lent him the mold to cast Amerindian religion as the expression of a complex activity of indigenous reasoning that fit neatly into the patterns of natural law and that had reached the summit of what it could attain without the assistance of Christian faith. Las Casas' intellectual achievement is an expression of a distinctive attribute of colonial letters identified by Adorno, that of simultaneously occupying positions in multiple disciplines when laying out an argument (Adorno 1988: 14). In the context of his Apologética Historia, the bishop's reliance on the manifold implications and sources of 'opinion' and its power to engage the main disciplines of his time - theology and the law - allowed him to make a compelling argument, one that found within the extraordinary circumstances of the indigenous cultures' abilities and beliefs that simultaneously responded to universal principles and were incarnated in specific, particular forms, none of which constituted grounds for just war and colonial domination. 


\section{Works Cited}

Adorno, Rolena. "Nuevas perspectivas en los estudios literarios coloniales hispanoamericanos." Revista de Crítica Literaria Latinoamericana 28 (1988):11-28.

Adorno, Rolena. The Polemics of Possession in Spanish American Narrative. New Haven: Yale University Press, 2008.

Albertus Magnus, Saint. Opera Omnia. Ed. Augusti Borgnet. Paris: Ludovicus Vives, 189 o.

Aquinas, Thomas. Commentaria in Omnes Epistolas Beati Pauli Apostoli. Basel: Michael Furter, 1495.

Aquinas, Thomas. Summa de Veritate. Colonia, 1497.

Aquinas, Thomas. Summa Sacra Theologia S. Thomae Aquinatis, doctoris angelici cum comentariis R.D.D. Thomae de Vio Caietani. Hildesheim: Georg Olms Verlag, 2000.

Aristotle. On the Soul. Transl. W.S. Hett. Boston: Harvard University Press, 2000.

Aristotle. Topica. Transl. Hugh Tredennick and E.S. Forster. Boston: Harvard University Press, 2004.

Albernus, Guglielmus. De fide et legibus [1249]. Habsburg: Günther Zainer, 1476.

Capéran, Louis. Le Problème du Salut des Infidèles. Essai historique. Toulouse: Grand Séminaire, 1934 .

Cárdenas Bunsen, José. Escritura y derecho canónico en la obra de fray Bartolomé de las Casas. Madrid: Iberoamericana Vervuert, 2011.

Carman, Glenn. "Human Sacrifice and Natural Law in Las Casas' Apologia." Colonial Latin American Review 25.3 (2016): 278-299.

Casas, Bartolomé de las. Apologética Historia Sumaria. Ed. Juan Pérez de Tudela Bueso. Biblioteca de Autores Españoles 105-106. Madrid: Atlas, 1958.

Casas, Bartolomé de las. Historia de las Indias. Edited by Agustín Millares Carlo with an introductory study by Lewis Hanke. México, Fondo de Cultura Económica, 1995.

Casas, Bartolomé de las. Apología o declaración y defensa universal de los derechos del hombre y de los pueblos. Ed. Vidal Abril Castelló. Salamanca: Junta de Castilla y León, 2000.

Casas, Bartolomé de las. “Aquí se contiene una disputa o controversia entre el obispo don fray Bartolomé de las Casas ... y el doctor Ginés de Sepúlveda, coronista del emperador." Tratados: 216-459.

Casas, Bartolomé de las. "Este es un tratado que el obispo de la Ciudad Real de Chiapas, don fray Bartolomé de las Casas o Casaus, compuso, por comisión del Consejo real de las Indias, sobre la materia de los indios que se han hecho en ellas esclavos." Tratados: 500-641.

Casas, Bartolomé de las. Obras completas. Madrid: Alianza Editorial, 1995.

Casas, Bartolomé de las. Tratados. Mexico: Fondo de Cultura Económica, 1997. 
Catholic Church. Liber Sextus Decretalium cum apparatu Johannis Andreae. Roma: Ulric Han et Simon Chardella, 1472.

Corpus Iuris Civilis. Eds. Theodor Mommsen and Paulo Krueger. Berlin: Weidmann, 1928.

Deman, Th. "Probabilis." Revue des Sciences Philosophiques et Théologiques 20 (1933): 26o-29o.

Ferraris, Lucio. Bibliotheca canonica, juridica, moralis, theologica. Venice: Vincent Radici, 1770.

Gardeil, A. "La Certitude Probable." Revue des Sciences Philosophiques et Théologiques 5 (1911): 237-266, 441-485.

Innocent IV. Apparatus super Libros Decretalium. Venice: Joannes Herbort, 1481.

Lantigua, David. "Religion within the Limits of Natural Reason: The Case of Human Sacrifice." Bartolomé de las Casas, O.P. History, Philosophy and Theology in the Age of European Expansion. Eds. David Thomas Orique, O.P. and Rady Roldán-Figueroa. Leiden: Brill, 2019: 280-309.

Lantigua, David. Infidels and Empires in a New World Order. Early Modern Spanish Contributions to International Legal Thought. Cambridge: Cambridge University Press, 2020.

Losada, Angel. "The Controversy between Sepúlveda and Las Casas in the Junta of Valladolid." In Bartolomé de las Casas in History. Toward an understanding of the Man and his Work. Eds. Juan Friede and Benjamin Keen. Dekalb, IL: Northern Illinois University Press, 1971: 279-308.

MacCormack, Sabine. Religion in the Andes: Vision and Imagination in Early Colonial Peru. Princeton, NJ: Princeton University Press, 1991.

Michaud-Quantin, P. “Albert le Grand et les Puissances de l'Ame." Revue du Moyen Age Latin 11 (1955): 59-86.

Muldoon, James. Popes, Lawyers and Infidels. The Church and the Non-Christian World 1250-1550. Philadelphia: University of Pennsylvania Press, 1979.

Richard, R.P. Le Probabilisme Morale et la Philosophie. Paris: Nouvelle Librairie Nationale, 1922.

Sepúlveda, Juan Ginés de. "Apología en favor del libro sobre las justas causas de la guerra." Obras Completas III. Ed. A. Moreno Hernández and transl. Ángel Losada. Pozoblanco: Ayuntamiento de Pozoblanco, 1997.

Silva Tena, Teresa. "El sacrificio humano en la Apologética histórica." Historia Mexicana $16.3(1967): 341-357$.

Wagner, Henry Raup/Helen Rand Parish. The Life and Writings of Bartolomé de las Casas. Albuquerque: The University of New Mexico Press, 1967.

Wey Gómez, Nicolás. The Tropics of Empire. Why Columbus Sailed South to the Indies. Cambridge, MA: The мiт Press, 2008. 


\title{
Staging Penance: Scenes of Sacramental Confession in Early Modern Spanish Drama
}

\author{
Hilaire Kallendorf
}

\begin{abstract}
Scholars now recognize that the language of casuistry pervades early modern Spanish school dramas, comedias and autos sacramentales, due to the Jesuit education received by a majority of Renaissance Spain's renowned playwrights. A closer scrutiny of a corpus of 8 oo digitalized plays from this period - supplemented by plays held in manuscript at Madrid's Royal Academy of History - reveals an even closer connection between the ritual act of the Catholic Church's sacrament of confession and the early modern Spanish stage.
\end{abstract}

\section{Keywords}

Penance - confession - casuistry - Jesuits - school dramas - comedias - autos sacramentales - ritual - sacrament

Sacramental confession in the comedias, autos sacramentales and Jesuit school dramas appears in everything from short off-the-cuff references to extended scenes to even play titles and main themes. This is the case not only in early modern Spanish drama but also on the stage in early modern England:

The traditional [penitential] rite appeared with noticeable regularity in almost every dramatic genre, ranging from early modern history plays (Peele's Edward I and Shakespeare's Henry VIII) to comedies and tragedies set in Catholic countries (Measure for Measure, Romeo and Juliet, Much Ado About Nothing, and Ford's 'Tis a Pity She's a Whore) to anti-Catholic polemical dramas (Bale's King Johan, Marlowe's Jew of Malta, Webster's The Duchess of Malfi, and Middleton's A Game at Chess). Either in terms of England's religious past or contemporary examples on the Continent, the connection between ritual confession and Roman Catholicism 
constitutes the common theme in the majority of early modern dramatic representations of the rite.

STEGNER 107

I was perhaps the first to point out that "vernacular Jesuit dramas form a lynchpin of the case for finding a new basis of an alternative poetics for the comedia in the techniques of casuistry" (Kallendorf 2007: 12). In recent years, however, increasingly scholars are beginning to trace the relationships among these three kinds of theatrical production (i.e. 'secular' comedias, Jesuit school dramas, and the more liturgical autos sacramentales) and to recognize that they are not so easily disentangled from one another as previous generations of researchers might have thought. ${ }^{1}$ More and more often now, one finds declarations of mutual influence and synergy such as "podemos inferir la influencia del teatro comercial en el de colegio a través de los profesores y estudiantes en su papel de espectadores" (Montiel Contreras 67).

It has by now been established that casuistry, or case morality, forms the basis for a poetics of early modern Spanish theatrical production. ${ }^{2}$ But up until this point the study of casuistry in the drama has focused on topics such as the recurring question "¿Qué he de hacer?" along with descriptions of a clean or guilty conscience; the appearance of trademark phraseology from the casuists' linguistic register such as casos, indicios, circunstancias, motivos, laberintos (Kallendorf 2019); and the negotiation of particularly thorny ethical dilemmas such as the classic double bind (Kallendorf 2007). What has been lacking is the scrutiny of scenes where the actual sacrament (or its equivalent) appears, given that casuistry as a discourse finds a point of origin inside the confessional box. Montiel Contreras highlights the importance of confession scenes for Jesuit drama specifically:

Los jesuitas recorrían el escalafón social por medio de la confesión, ya que el sacramento era clave y expresión de la fe o de la conversión del creyente y marcaba su inicio hacia el camino de la salvación [...] Si el hombre gozaba de albedrío para evitar el pecado y superar la tentación, se debía a la guía de conciencia y a la confesión suministradas por la

1 For further instances of cross-fertilization among early modern Spain's various dramatic traditions, see González Gutiérrez 1991 and González Gutiérrez 1997.

2 As Antonio Sánchez Jiménez asserts of my Conscience on Stage, "Este trabajo fue pionero en el campo y se revela una obra de consulta tan obligada como útil” (Sánchez Jiménez 577). 
Compañía, que intentó por todos los medios - y el teatral fue uno de los predilectos - reducir esa posibilidad física y moral de que los devotos erraran sus pasos.

MONTIEL CONTRERAS 60

This chapter will analyze six representative plays by four playwrights, from a variety of genres, to determine what we can learn about early modern casuistry in its explicitly sacramental form through its portrayal on the stage.

As I noted in Conscience on Stage: The Comedia as Casuistry in Early Modern Spain: "the school dramas are rife with references to sacramental confession" (Kallendorf 2007: 28). However, I only devoted a single page of that book to describing some of these references. One occurs in Francisco Ximénez's Diálogo hecho en Sevilla when the character Dolus declares: "Confieso las cuaresmas/ como los buenos cristianos" (Ximénez, vv. 2208-2209, 1: 380). Another is in Juan Bonifacio's Triumphus Circuncisionis when Circuncisio asserts, "Pareçe me amí que era neçessario aun maestro guardar grauedad paternal, dando buenos consejos alos disçipulos haziendolos confessar amenudo" (Bonifacio, Triumphus Circuncisionis: 31v).

I did not in that book discuss scenes of sacramental confession per se in the autos sacramentales or 'secular' comedias. In the category of off-the-cuff or humorous remarks about the sacrament of penance in these other kinds of plays, we might include the following humorous dialogue between Rodulfo and Carloto in Lope de Vega's El Marqués de Mantua (1596): ${ }^{3}$

$\begin{array}{ll}\text { Carloto: } & \begin{array}{l}\text { Que al Rey es mucha justicia } \\ \text { darle aquello que codicia. }\end{array} \\ \text { Rodulfo: } & \begin{array}{l}\text { Cuando codicia lo injusto, } \\ \text { no es justicia hacerlo justo, } \\ \text { sino pecado y malicia. }\end{array} \\ \text { Carloto: } & \text { ¿Pecado? } \\ \text { Rodulfo: } & \text { Pecado digo. }\end{array}$

3 This is the date of a manuscript of the play held in the Colección Gálvez (Antonucci 2005: 64, n. 17), so named for the copyist Ignacio Gálvez (Pedraza Jiménez 2007b: 17). As Felipe Pedraza points out, this date places the work near the end of the first phase of Lope's career, with its composition occurring shortly before the closing of theaters 1597 due to Catalina de Saboya's death: "El marqués de Mantua de Lope de Vega, se acabó de redactar, según el manuscrito Gálvez, el 10 de enero de 1596, es decir, hacia el final de la primera etapa de la dilatada trayectoria del dramaturgo, poco antes de la suspensión de las representaciones en 1597, a raíz de la muerte de Catalina de Saboya" (Pedraza Jiménez 2007: 129). 


\section{Carloto: ¡Qué teólogo revuelvo! ¿Confiésome yo contigo? \\ Rodulfo: $\quad$ Pues por eso no te absuelvo. LOPE DE VEGA, acto 1, Vv. 196-204, 36-37}

Luisa Rosselló Castillo sums up the picture presented in this scene: "A través de Carloto, se escenifica lo que ocurre cuando un príncipe es incapaz de domeñar sus pasiones y de controlar sus impulsos" (166). The text's modern editor, Felipe Pedraza, adds the following gloss to this passage: "Las ideas políticas aquí desarrolladas vienen a coincidir con las que hacia 159 o consignaba Juan de Mariana en De rege et regis institutione, en especial en el cap. V del libro I" (Lope de Vega, 36 nı89-210). He also notes that Mariana's book was burned publicly in Paris after the assassination of Henri IV (Pedraza Jiménez 2007b: 28). Rosselló Castillo even demonstrates that Lope de Vega knew the Jesuit priest Juan de Mariana personally and wrote him two letters in 1620, in one of which he specifically requests that Mariana send him two texts on the topic of "la razón con que se pueda gobernar un señor en sus estados, así personalmente como con sus súbditos y vasallos, y en la administración de su justicia y segura conciencia tratar las jurisdiciones eclesiásticas y seglares y acudir a toda obligación cristianamente" (Lope de Vega, Epistolario 280, quoted in Rosselló Castillo 150).

Here we find a seemingly humorous exchange with serious undertones about a prince wanting what he should not have - in this case, his cousin's wife - and pushing past the limits of royal authority. ${ }^{4}$ The object of Carloto's desire is the Muslim princess Sevilla, recently wedded to Baldovinos. Carloto - still a prince,

4 Pérez García confirms that this passage of Lope's play contains "la reflexión sobre los límites del poder de un rey y el conflicto entre los derechos de sus súbditos y la voluntad y el deseo de su señor [...] El problema que se desarrolla en la obra no es cuestionar la autoridad real sino discutir los derechos y limitaciones de poder de un rey injusto [...] El problema se presenta cuando se confunden las leyes con el poder arbitrario, con la tiranía" (Pérez García 2001, 191, 195). Rosselló Castillo sees this play of Lope's as part of a more general pattern or subgenre of works in which the playwright meditates on the nature of monarchy: "el interés de estas [...] obras radica en el hecho de que Lope juegue a mostrarnos a un joven representante de la monarquía que no se ajusta a un modelo ideal, que no se comporta tal y como se esperaría de él [...] Es la actuación de estos [...] herederos a la corona la que se convierte en el desencadenante del conflicto dramático y provoca situaciones controvertidas o espinosas que permiten a Lope plantear sus dudas y reflexiones sobre lo que implica ser rey y sobre qué se debe hacer cuando un representante de la monarquía no obra como le corresponde. Son obras que resultan sugestivas, de igual modo que lo son otras comedias en las que es el mismo rey quien sucumbe a una pasión amorosa no correspondida, o bien, no conveniente" (Rosselló Castillo 149). 
not yet a king - is the son of Charlemagne; he uses his rights as heir to the kingdom to justify indulging his adulterous desires: "Carloto se recuerda a sí mismo su condición real para justificar así, primero, sus adúlteras intenciones con Sevilla, y después el premeditado asesinato de su marido Valdovinos" (Espín Templado 169). Espín Templado describes the mental contortions Carloto goes through in an attempt to justify his actions:

El móvil del asesinato es, pues, la pasión, pero el pretexto que sirve a Carloto para acallar su conciencia, será su sangre regia, esto es, el ser príncipe heredero; este poder real es lo que le confiere, según sus falaces razonamientos y los de su mal consejero Galalón, el derecho de hacer su voluntad, basándose en una errónea concepción del poder de la monarquía. (168)

This scholar also notes the malign influence of Carloto's counselor Galalón in persuading him to embark upon an immoral course of action: "Galalón intenta persuadir a Carloto de los derechos ilimitados que le confiere su sangre real, convenciéndolo además de que si en algo se extralimita, el Rey le perdonará por ser su padre" (Espín Templado 170). Pérez García notes that Galalón has a personal motive of revenge for leading Carloto astray: "La presencia de Galalón en la traición tiene su importancia ya que es él quien ha sugerido a Carloto la muerte de Valdovinos y quien se venga personalmente de una afrenta anterior" (Pérez García 194). This personal affront was a slap to the face Galalón had received from one of Baldovinos's relatives. Pérez García also insists that Carloto knows what he is doing is wrong and never fully manages to convince himself that his actions are justifiable:

En efecto, Carloto sabe desde el principio que su acción es injusta y pide perdón a Dios. Pero en lugar de quitar de sí la tentación, primero intenta forzar la voluntad de Sevilla. Pero como sabe que el matrimonio está por encima, como sacramento, de su autoridad, opta por eliminar el obstáculo que impide su satisfacción personal eliminando a Valdovinos.

PÉREZ GARCÍA 196

Intriguingly, Pedraza Jiménez sees a possible parallel between Carlomagno and his son Carloto in the play and the Spanish King Felipe II and his son Carlos in real life:

Esto se escribe en las postrimerías del reinado de Felipe II. Los contemporáneos pudieron ver en el Carlomagno dramático una contrafigura del rey prudente. No hay que olvidar que en la realidad histórica un heredero de la corona española había muerto confinado en el castillo de Arévalo. 
Don Carlos, el primogénito de Felipe II, falleció el 24 de julio de 1568. No parece haber duda sobre los trastornos sicofísicos del príncipe, pero también es cierto que en su insania fantaseó con huir a los Países Bajos, probablemente con la intención quimérica de hacerse fuerte junto a los descontentos con la política de su padre [...] Carlomagno en el drama, Felipe II en la historia próxima someten a su primogénito a la ley general y no toleran sediciones en su apoyo.

PEDRAZA JIMÉNEZ 145-46

As we can see clearly from this scene's gravely serious political import, in reality it ends up not sounding funny at all. But most of the scenes which center around the sacrament of penance (or reconciliation, as it is now officially called by the Catholic Church) were never in fact meant to be funny, instead elaborating on the dire need for this religious ritual, whether it ends up being possible for the characters to consummate it or not. For example, in the same play by Lope de Vega the dying Baldovinos - who has been murdered by order of Carloto during a hunting trip in an effort to steal his bride, Sevilla - implores his servant Marcelo to go find him a priest to hear his last confession and administer extreme unction:

\begin{tabular}{|c|c|}
\hline $\begin{array}{l}\text { Baldovinos: } \\
\text { Marcelo: }\end{array}$ & $\begin{array}{l}\text { Llámame un confesor. } \\
\text { ¿Estás herido } \\
\text { de muerte? }\end{array}$ \\
\hline Baldovinos: & Luego un confesor me llama. \\
\hline Marcelo: & ¡O Carloto crüel! \\
\hline Baldovinos: & ¿Aún no eres ido? \\
\hline & Quien ama el cuerpo, el alma aquí desama. \\
\hline Marcelo: & $\begin{array}{l}\text { Voy en mi propio llanto convertido, } \\
\text { que el alma por los ojos se derrama. }\end{array}$ \\
\hline Baldovinos: & $\begin{array}{l}\text { ¡Triste de mí, que han muerto al señor mío! } \\
\text { ¡Jesús, nombre piadoso, en vos confío! }\end{array}$ \\
\hline & $\begin{array}{l}\text { Quiero sentarme aquí por animarme, } \\
\text { aunque desmaya la mortal flaqueza, } \\
\text { y al cielo, que me escucha, confesarme. }\end{array}$ \\
\hline
\end{tabular}

This scene starts to look for all the world like a do-it-yourself confession without the assistance of a priest. Ruiz del Vizo insists, however, that Catholic ritual is followed to the letter: "Baldovinos, antes de expirar, cumple con todos los preceptos de la religión católica, apostólica y romana, pide confesión, mira a la cruz, y tres veces en sus últimos momentos, pronuncia el nombre de Jesús" 
(62). Later in the play the servant Marcelo does manage to find a hermit (a Carthusian monk) to come to the aid of his master:

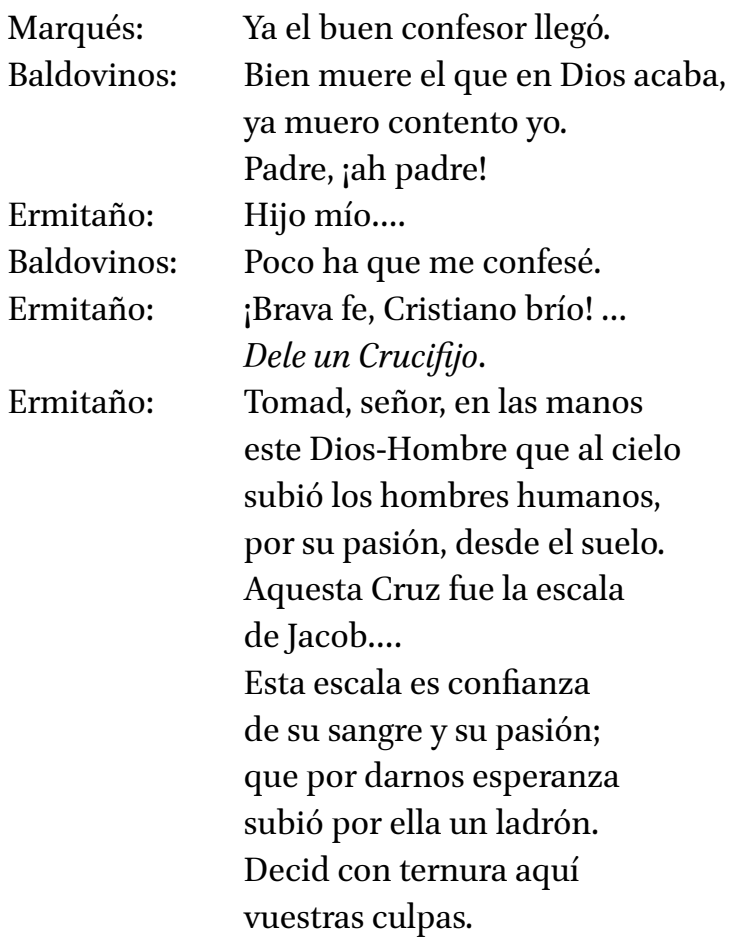

LOPE DE VEGA acto 2, vv. 1727-1749, 99-100

Chouza-Calo remarks concerning the extraordinary length of this scene, "Lope representa el momento en el que Valdovinos muere en brazos de su tío el Marqués de Mantua, pero lo hace escenificando una muerte agónica cargada de patetismo que se prolonga durante 386 versos [...] comparándola por momentos con la pasión de Cristo" (1). Ruiz del Vizo shares this heroic view of Baldovinos:

Baldovinos se presenta ante la vista de todos como cristiano perfecto. Atiende, en trance de muerte, a lo que un buen cristiano debe atender: a la salvación de su alma. Y atiende a ella antes que a la injusticia de su muerte. Su humildad llega al cenit. Un par, lejos de pedir justicia, como es de costumbre de acuerdo con las leyes de la nobleza y del feudalismo, sólo piensa en lograr la salvación en Dios [...] Es lo que puede llamarse una feliz muerte cristiana.

RUIZ DEL VIZO 52-53 
This longer confessional scenario sounds much less like a do-it-yourself version of the sacrament. But there is still no confessional box (first introduced by Carlo Borromeo after the Council of Trent), ${ }^{5}$ no how-to manual (confesionario or libro de confesores $),{ }^{6}$ no interrogation by the priest of the penitent regarding specific sins, and no formal absolution. The lack of absolution bears especially poignant resonances, as Paul Stegner explains for the early modern English context:

In the medieval administration of confession, penitents could ideally find inward assurance of the effectiveness of their spiritual performance of confession in its ritual form, especially through the priest's speaking of the rite of absolution and the laying on of hands.

STEGNER 112

So while he does in the end receive spiritual consolation from a priest, Baldovinos' confession happens without all the trappings of sacramental ceremony. Felipe Pedraza remarks upon the minimal role played by the Catholic Church in this play: "en el drama la iglesia no tiene más papel que el consuelo que presta 'un venerable cartujano' a Valdovinos en su agonía y a Carloto en el momento de subir al cadalso" (Pedraza Jiménez 2007:142).

In what is (in a sense) a similar example, albeit with opposite outcome, we turn from the open-air corrales of public theater in Spain to the Jesuit school dramas. With almost uncanny proto-Derridean logic, sometimes the sacrament of penance is most "present" on stage by virtue of its conspicuous absence. For instance, we might consider the case of a school drama by Juan Bonifacio. A Jesuit priest, professor and dramaturg, Bonifacio (1528-16o6) was teacher to Saint John of the Cross (González Gutiérrez 1999: 3). He studied Latin and rhetoric at the University of Alcalá de Henares, but law at the University of Salamanca (Kallendorf 2012: 117). Juan Bonifacio's Tragedia Nabalis is a tragicomedy in five acts, composed ca. 156o-1575, and performed at a Jesuit college in Medina del Campo (González Gutiérrez 1999: 472, 488). In this play, Nabal's wife Abigail perceives that he is dying and urges him to confess his sins before it is too late:

5 "In Milan, the Archbishop Carlo Borromeo introduced (in 1565) a new wooden structure called a 'confessional' in which penitents could preserve their anonymity while confessing their sins" (Kamen 197).

6 The manuals of casuistry which proliferated so extensively during this time period have been studied by Elena del Río Parra. 
Abigail: Mirá, señor, que os morís y tenéis necesidad de descargar vuestra conciencia. Mirá que tenéis mucho de que dar cuenta. Proveéos dende ahora. Tened por gran misericordia de Dios este poquillo que os queda de vida. Momento es del cual depende una eternidad de siglos [...] Acordáos de aquella tía que tenéis pobre; mandadle alguna cosa, que es buena mujer. El pleito que trujistes con Alonso de los Hoyos fue injusto, y contra toda razón le hicistes gastar lo que no tenía. Hazedle alguna satisfacción ahora. ¿Qué os cuesta? ¿Habéislo de llevar con vos? Hazed cuenta que dais de lo ajeno. ¿Qué os cuesta? Sed liberal, siquiera en la muerte.

But Nabal persists without repenting:

Nabal: No acabará hogaño esta bachillera. Déjame, no sabes lo que dices. Yo he vivido muy limpiamente; no tengo de qué hacer escrúpulo. BONIFACIO 2001a, act 4, scene 2, 390-91

Nabal dies in his delusion. Montiel Contreras confirms, "La agonía de Nabal frente al público queda totalmente justificada no tanto por la ofensa ante David, sino por haber despreciado la ocasión para arrepentirse y examinar su conciencia frente a su esposa" (65). Similarly, in another play titled Actio Nepotiana by this same author, Juan Bonifacio, a female character named Sotela mourns for her unrepentant husband's spiritual death even more than for his physical one: “ $\mathrm{i}$ desastrada muerte sin confesión!" (Bonifacio, Actio quae inscribitur Nepotiana Gometius $5 \cdot 4,136 \mathrm{v}) .{ }^{7}$ Abigail goes on to marry none other than King David, which constitutes a considerable upgrade from her first husband, who was foolish and disagreeable. As the Biblical text explains, Nabal's name means "fool" (1 Samuel 25:25). In the Old Testament version Abigail says of her husband to King David: "Let not my lord the king, I pray, regard this naughty man Nabal: for according to his name, he is a fool, and folly is with him."

Still other works provide a contrast between failed and successful confessions within a single play through vignettes of different sinners and their repentance or lack thereof. As I put it in Conscience on Stage, invoking French philosopher Jacques Derrida, "There are also poignant scenes of confession and absolution in the school drama as well as Derridian lacunae where the absence of confession bespeaks its presence" (Kallendorf 2007: 28). A case in point is Juan Bonifacio's Triumphus Eucharistiae, an auto sacramental in five

7 My previous comment on this play still holds: "Here again we see a reference to sacramental confession and the painful consequences following its neglect" (Kallendorf 2007:32). 
acts, composed ca. 1567-1576, which was performed at the Jesuit Colegio de San Gil in Ávila (González Gutiérrez 1999: 472, 491) to celebrate the feast of Corpus Christi (Bernardo de Quirós Mateo 22, 231). Note the summary of the action read by Interpres at the start of the show:

Tratarse ha con el favor de Dios, en nuestra breve representación, un triunfo de la divina Eucaristía y Santíssimo Sacramento. Y porque los que bien comulgan reciben vida y, por el contrario, los que se llegan en pecado caen en muerte del alma, pareció ser traza conveniente introducir la Justicia divina, la cual ejecuta riguroso castigo en un pecador obstinado que no solamente vive mal, pero [i.e. sino] también persigue a los buenos y devotos. Después, la Caridad, reina y princesa de las virtudes, triunfará de cuatro hombres buenos y justos, en los cuales se cifran todos los estados y maneras de vivir que hay en la república cristiana, de suerte que al primero justiciarán los ministros de Dios, por indevoto y enemigo de los sacramentos y, finalmente, por malo y perverso; mas a los otros el amor divino los acariciará y sentará a la mesa y banquete celestial de la Hostia consagrada, porque [i.e. para que], emendados de sus faltas y descuidos comulgan con gran aprovechamiento suyo y buen ejemplo del prójimo.

BONIFACIO 20O1b: 610-11

Montiel Contreras explains the general function of the "Interpres" in the school dramas: "En esos prólogos un curioso personaje, el 'Intérprete', da aviso al público, siempre en lengua romance, de lo que pasará en cada uno de los actos" (63).

Eventually in Bonifacio's Triumphus Eucharistiae the allegorical figures of Justice and Charity come out onstage tied together with a knot, followed by a student actor who explains their appearance:

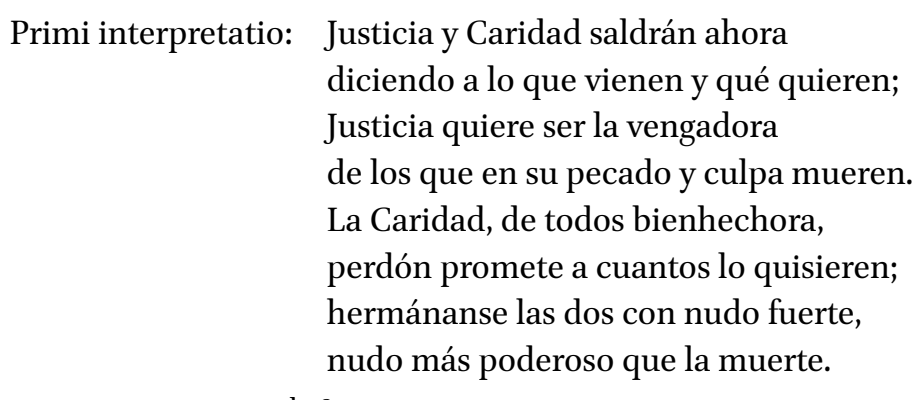

BONIFACIO 20O1b: 611

Justice appears on stage in an apotheosis as the goddess Astraea and urges the people to repent: 
Astraea: Yo soy la que al mundo doy pena y tormento, yo soy el azote de Dios enviado, yo soy el espanto del más esforzado, al fuego perpetuo doy soplo y aliento. Al bueno pagamos su buen miramiento, si esclavo, si libre, si siervo o señor, las leyes se guardan en todo rigor; también castigamos el mal pensamiento. Descarga con tiempo tu mala conciencia, alimpia tus males, enmienda la vida, el alma remedia que tienes perdida, la tabla te valga de fiel penitencia. Con esto no temas la dura sentencia, mas antes camina con rostro sereno causado de un pecho católico y bueno. Comulga también con gran reverencia. BONIFACIO 2OO1b: 612-13

Astraea's sister Charity affirms her message, but this time with a carrot instead of a stick:

\author{
Charitas: Triunfo ganar queréis \\ del pecador obstinado, \\ pero yo del emendado.... \\ Vos usá de ese rigor \\ con el hombre endurecido, \\ rigor justo y merecido. \\ Yo trataré con amor \\ al que viere arrepentido. \\ Castigad vos a los rotos \\ que convertirse no quieren, \\ mas en su pecado mueren. \\ Yo premiaré los devotos, \\ los que mi bando siguieren. \\ BONIFACIO 2001b: 613
}


At the start of the second act, another actor offers a summary of what is about to transpire in the "Actus Secundi Brevis Expositio":

Dos hombres penitentes y cristianos

alaban al Señor de lo criado.

Habiendo los dos sido antes livianos,

escupen y abominan su pecado.

BONIFACIO 20O1b: 623

The first repentant sinner, Metaneus, then tells his story:

He sido tan pecador

y a tanto extremo llegué,

como si fuera error

lo que nos dice la fe

y afirma el predicador.

Fue mi vida tan si vida,

tan sin rienda mi correr

que, viendo el alma perdida,

gustaba de la perder,

aunque por Dios redimida.

Quisiera ser inmortal

no en la gloria ni en el cielo,

mas como bruto animal

para tener en el suelo

paraíso terrenal.

Era el mismo Lucifer

cuanto toca al pensamiento.

Lo que dejé de hacer

no era por miramiento,

sino por más no poder.

Mas, al fin, el Dios eterno,

usando de su clemencia,

me sacó de tal infierno

y me trajo a penitencia

$\mathrm{y}$ a vida de buen gobierno.

BONIFACIO 2OO1b: 624-25 
Then Cosmoparus (a.k.a. Aloysio) comes out to tell of his own repentance:

¡O triste de mí, pobre y desdichado, que en tal error viví y en tal ceguera! Regíme por reloj desconcertado; mi vida fue un dislate toda entera; con verme tan enfermo y tan llagado la cura no tomaba verdadera.... $¡ O$ qué gozo y qué contento da la limpia conciencia! Aun hasta la penitencia es un sabroso tormento.... Parece ser ya de esencia la maldad y pestilencia del honrado, y que es grandeza y estado huir de la penitencia. Mas, si a dicha se levanta de la cama de sus vicios y a Dios hace sacrificios, otro gallo ya le canta.

Si a menudo se confiesa, paga sus deudas a priesa, da ejemplo, su morada es en el templo y no con gente traviesa. BONIFACIO 2OO1b: 626-28

Metaneus responds with the injunction, "Demos gracias al Señor [...] y pidámosle humildemente que nos perdone los pecados que en semejantes acompañamientos solíamos cometer" (Bonifacio 20o1b: 628).

Later in the play, in a different vignette, Suasor tries to persuade Paradoxos (a.k.a. Gonzalo Pleiteros) - who has fallen ill - to repent before he dies:

Suasor: Mire, mi señor, que se muere; confiésese, por su vida; que todo es aire. Ponga su alma bien con [....] Mire, señor Gonzalo Pleiteros, que le toman todos los diablos, confiésese. ¿Quiere que le llamemos los Padres de S. Gil?

BONIFACIO 2001b: 636-37 
But like Nabal, Paradoxos resists this suggestion: "Paradoxos: Cuando vos os querías morir, los llamá, que os lean la Pasión y os esfuercen, que yo no he menester nada de eso" (Bonifacio 20o1b: 637). Then Melampelus comes along to try likewise to convince him to repent:

Melampelus: ¡Señor mío! ¡A, señor mío! Acuérdese de Dios. Aquí vengo a consolar a v.m. y para que tratemos de las cosas de su alma. Haga testamento y confiésese. Cumpla con Dios y con el mundo. Mire que ha vivido mal.

BONIFACIO 2001b: 637

But still Paradoxos refuses to confess, trying to convince himself that his sins aren't so bad after all:

Paradoxos: Sálganse todos, y vos el primero. Déjame aquí, que no estoy tan malo como eso. No me muero.

BONIFACIO 2001b: 638

At this instant, he does die, and Suasor laments: " $\mathrm{O}$ desastrada muerte sin confesión! ¡ $\mathrm{O}$ alma desdichada! ¡O dureza infernal! ¡O triste hado! ¡O pobre hombre!" (Bonifacio 20o1b: 638). The Chorus sums up the message of the play:

Chorus: Despierta, pecador, y ablanda el pecho, no tengas ya tan duras tus entrañas, camina por do[nde] vayas más derecho. BONIFACIO 2001b: 638

In the humorous finale, Aloysius plays confessor to his fellow rustic Leucosirus by walking him through a rudimentary examination of conscience:

Aloysius: Veamos, hermano, entre semana ¿ireñís con vuestros vecinos, enojáisos de pocas cosas, echáis maldiciones, juráis, murmuráis del cura, sois duro de condición, andáis en temas y pleitos? BONIFACIO 2001b: 647

The simpleton Leucosirus admits he used to do these bad things, but affirms proudly that he has reformed his life and does not do them any longer. In a different study I referred to this scene as "a public Jesuit stamp of approval upon this alternative, non-noble path to piety" (Kallendorf 2012: 122).

As I noted in Sins of the Fathers, sometimes "the language of sacramental confession $[\ldots]$ seems to be more about repeating the reassuring words of ritual, 
'yo confieso,' than about receiving absolution from the priest" (Kallendorf 2013: 148). The clearest example of formal sacramental confession I have found in early modern Spanish drama is in Calderón's auto El año santo de Roma. In it, the allegorical figure of Culto challenges Hombre to confess his sins and receive pardon:

Culto: Confiesa al verte

rendido a ese asombro fuerte,

que erraste.

Hombre: Ya lo confieso.

Culto: Pues yo llegaré con eso

ahora a favorecerte, que dando tú a tu Albedrío

la mano, él a tu Temor,

tu Temor a mí, el favor

del Perdón traerte confío.

CALDERÓN DE LA BARCA 1995, vv. 1658-65, 94-95

Later Amor explains this whole process to Hombre:

Amor: Cuando postrado te veías

y a Dios de temor llamabas,

no era, no, porque le amabas,

sino porque le temías;

y así, las piedades mías

no aliviaron tu pasión,

hasta que en la confesión

pudiste el acto elevar,

que Amor no puede alcanzar

donde no alcanza el Perdón.

Y aunque el haberme alcanzado,

cuando estoy de ti ofendido,

por la mano izquierda ha sido,

esa es la que yo le he dado,

porque desde tu pecado

no me alcanzaste; mas hecha

la confesión, te aprovecha

tanto, que siendo atrición

la izquierda, la confesión

la vuelve mano derecha. 
La indulgencia a que vienes, que aquí se explica, imagino, pues te da el Culto Divino el grado que tú no tienes; por él el Perdón previenes que no pudieras por $\mathrm{ti}$ prevenir, pudiendo aquí la Gracia que yo prometo, hacer de un acto imperfecto un perfecto acto, y así, cuando por solo temor me llamaste, no llegué; tras Culto y Perdón sí, que al Temor con su favor le da su Gracia su Amor, con que probar solicito, que el Sacramento infinito de Confesión, es bastante que el atrito se levante con méritos de contrito, y pues ahora lo estás aprovecha el tiempo ahora.

Levántase.

Teme.

Temor: Gime.

Perdón: Siente.

Albedrío: Llora.

Culto: Con eso volver podrás

donde el camino hallarás

que perdiste.

CALDERÓN DE LA BARCA 1995, vv. 1672-1717, pp. 96-98

Hombre reads aloud from Psalm 5 , the Miserere, to pray a prayer of contrition directly to God:

Hombre: [D]el libro de los días borra, Señor, iniquidades mías.

Con amplia gracia, pues tu gracia ha sido la viva fuente de inmortal pureza, lava las manchas en que me ha tenido 
el lodo vil de mi naturaleza, no porque conozco mi flaqueza y conozco que siempre conjurado va contra mí, conmigo mi pecado. Pero si confesándole acrisolo tu poder, de rebelde no me arguyas contra ti, pues, Señor, contra ti solo pequé, mi Dios, y en la presencia tuya, para que tú cuando de polo a polo a juzgar vengas, en la causa suya justifiques tu causa y me convenzas y con justicia y no poder me venzas; mas atiende, Señor, en la agonía del juicio que me aguarda prevenido que culpa de mi ser herencia es mía, pues que nací en pecado concebido.

Perdón and Culto then open the doors of the Temple to Man, signalling his absolution.

Whether or not a play includes this clear an example of sacramental ritual, the most telling indicator of whether a sinner has repented or not is a noticeable change in his or her behavior afterward. As the Jesuit playwright Guillermo Barçalo admonished the audience in his prologue to Tragedia de divite epulone, "Pido que la Tragedia no sea oyda,/por iuego, fiesta, o entretenimiento,/sino para de hoy mas mudar la vida" (cited in González Gutiérrez 1997: 228). In the early modern English tradition, Stegner quotes from a sermon contained in the Second Book of Homilies (1562), which states that "like Peter, true penitents 'must be cleane altered and chaunged, they must become newe creatures, they must be no more the same that they were before"' (Stegner 110). My assessment of this trend in Conscience on Stage was: "The explicit goal of the drama is to convince the spectators to change their lives" (Kallendorf 2007: 29).

This is the case in Calderón's comedia La exaltación de la Cruz. In the key scene, Eraclio laments that the sacred relic of the True Cross has been captured by infidels. He comes to realize his own responsibility for this disaster:

Eraclio: El sagrado Leño, que siendo arca de este diluvio, fue después de Dios humano el Carro, el Plaustro, y el Triunfo, Ultrajado; ;tal repito! 
de Bárbaros; ;tal pronuncio!

En Persia cautivo yace, sin estimación, y culto; ¡o mal hayan! ¡o mal hayan! Pero ¿̇a quién culpo, a quién culpo? ¿Si mis omisiones solas dieron materia a este insulto? Pero aunque conozco tarde el yerro que amor me puso; presto he de enmendarle, salga del lugar, donde le tuvo mal entretenido el ocio, mal aconsejado el gusto. Salga Eudocia de mi pecho, Rompe el Retrato.

y este hermoso objeto suyo, desperdiciado del aire, vuele en átomos menudos. Los aplausos de mis bodas, que el alborozo dispuso, trueque el dolor en exequias, sea el tálamo sepulcro.

No haya en mí valor, no haya en mi amor afecto alguno desde hoy, que en órden no sea a rescatar este sumo tesoro, sepa cobrarle, quien solo perderle supo.

Deudos, vasallos, y amigos, Eraclio César Augusto de Constantinopla os pide perdón del ocio en que os tuvo. CALDERÓN DE LA BARCA 1652: 67r-67v

He then lays out a plan for the True Cross's rescue:

En todo mi Imperio a un tiempo se escuchen ecos confusos de trompas, y cajas; pero bien pronunciado ninguno. Destemplado el parche gima, 


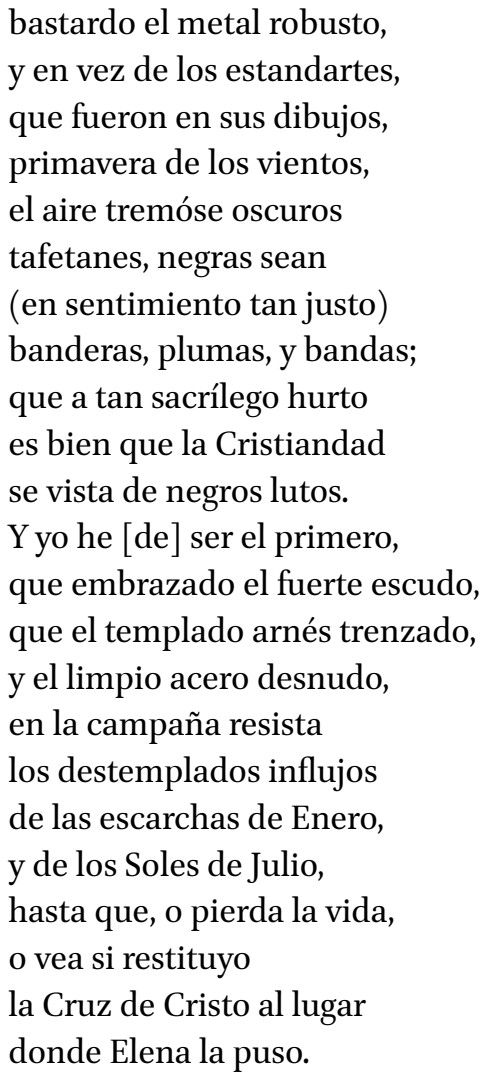

CALDERÓN DE LA BARCA 1652: 67v

He spends the rest of the play making valiant efforts to fulfill this vow.

Our final example of confession in the drama descends as with a microscope from macrocosm to microcosm, moving in the process to about a century later. In Luciano Francisco Comella's El dichoso arrepentimiento we find a case of true repentance declared out loud from offender to victim, but without the sacramental mediation of a priest. This may constitute a dramatic equivalent of the self-exorcism performed by Don Quijote which I have described elsewhere (Kallendorf 2002). In this play, Milord is an errant husband overcome by feelings of remorse who has returned to his abandoned wife Isabel (he had left her to chase after a wealthy woman due to his social ambition). María Angulo Egea locates this play within a broader context of social criticism aimed at lazy noblemen who found work distasteful: "Comedias como El dichoso arrepentimiento ... muestran el enfrentamiento que surge entre las antiguas concepciones y privilegios que otorgaba el honor nobiliario y las modernas ideas 
ilustradas que defienden los derechos de los virtuosos, aquellos que trabajan honradamente y hacen prosperar al país" (Angulo Egea 107). Stricken with regret, Milord laments:

No me recuerdes, esposa mis vergonzosos delitos. Ante tus ojos ¡oh Dios! me presento confundido entre mis torpes maldades.... Cómo al mirarte palpito.... Cómo me desnudo.... ¡Ay triste! ... ¡Cuánto tiempo te he tenido entre miserias! Si acaso disculparán mi delito los detestables consejos de Thovart, mi falso amigo, te diría.... Pero no, mis remordimientos mismos me acriminan.... ¡Mas qué miro! ¿Este pan grosero y tosco de alimento te ha servido? ¿Estos techos infelices te han proporcionado abrigo? ¡qué horror! ¿Para descansar de tus pesares continuos tenías el triste lecho que en el duro suelo miro? Estas penas que inocente por mi dureza has sufrido me parece que la saña excitan de los abismos. En vano esposa tu amor disculpa mis desvaríos; en vano me amas.... No tengo cosa alguna en favor mío que me pueda hacer capaz de tus piedades; yo mismo lo conozco. Eternamente en el seno del olvido 
debes tenerme; si esposa que me aborrezcas suplico sin que sobre mí derrames ningún rasgo compasivo. COMELLA [179o]: 24-25

He is horrified to find her living in such penurious conditions. Angulo Egea notes that this type of scene appears frequently in dramas by Comella:

Comella se sirvió de estas imágenes para conmover a los asistentes y para realzar la humanidad de aquellos que ayudaban a socorrer a estos menesterosos. El lado humano y especialmente emotivo de los monarcas y de los nobles ilustrados se veía reforzado con estas escenas. Por lo general, se presentaba a una familia con niños pasando hambre en una 'casa pobre,' rústica, sin más utensilios que una mesa, unas sillas y algún cacharro para cocinar, y con la omnipresencia del pan moreno como símbolo de la suma pobreza y único alimento de que se disponía. La casualidad hace que estas altas personalidades descubran semejantes cuadros y traten modestamente de aminorar los sufrimientos de estas familias [...] [E]stos retratos de miseria del pueblo no parecen pensados tanto para reflejar una realidad preocupante, como para reforzar por contraposición la imagen nueva de la monarquía y de la nobleza. Estas circunstancias lastimosas se deben a casos excepcionales, y a desgracias personales de individuos maltratados por algún tipo de injusticia concreta, que tiene que ver con la acción indigna de un malvado, que, al final de la comedia, será castigado, y la familia será también recompensada.

ANGULO EGEA 122, emphasis added

These generalizations about the rest of Comella's theatrical production make this play even more interesting; for in its ending, the villain is not punished, but instead repents of his sins in the confession scene which gives the play its title.

In response to this speech of contrition, his wife offers him - in the words of Charlotte Brontë's Jane Eyre - her "full and free forgiveness" (Brontë 1897, chapter 21):

Isabel: Calla, esposo, calla, y deja discursos tan desmedidos. ¿Cómo puede aborrecerte cómo ha de darte castigo aquella que en tu abandono 


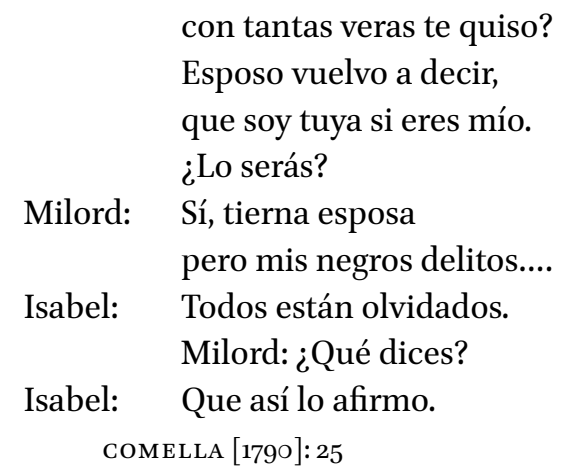

This heartwarming scene concludes with an additional reconciliation between father and daughter, as Isabel and Milord's offspring sees her parents together for the first time she can remember.

As I noted in Conscience on Stage,

We must realize that it is precisely the force of repetition that enables casuistry to leave such a noticeable trace: the annual repetition, year after year, of the sacrament of penance left a trace of the discourse of conscience even upon the most casual believer. How much more so would this be the case for priest/playwrights who may even have served as confessors themselves.

KALLENDORF 2007: 107

In the aggregate, these repeated scenes of confession, repentance, resolve to change or take action, and/or reconciliation constitute a corpus of works fundamental to our ongoing study of casuistry in early modern Spanish drama. ${ }^{8}$ Scholars such as Montiel Contreras have continued my work in this vein, confirming that "los escenarios del teatro religioso popular y de colegio recrearon espacios de ficción donde los personajes, a prueba y error, exploraron resoluciones posibles. Las normas cristianas de comportamiento fueron punto de referencia para calibrar actitudes y ocasiones particulares" (Montiel Contreras 70). Even more squarely placed in the realm of casuistry is the scholarship of Joan Oleza, who affirms for example regarding a similarity of method observed between Lope de Vega and Michel de Montaigne: "la casuística que ponen en escena las comedias del poeta español se corresponde con la que le sirve para argumentar al prosista francés, pues ambas proceden por medio del examen de casos" (Oleza 54).

8 See Kallendorf 2007, Kallendorf 2013 and Kallendorf 2017. 
Ranging from off-the-cuff, humorous references; to tragic death scenes in which the services of a priestly confessor are required; to injunctions to repent, where the sinner refuses these admonitions; to full sacramental ceremony; to everything in between, these case studies serve to solidify even further the argument that the poetics of early modern Spanish drama are based on the presentation of moral dilemmas and their myriad resolutions on the stage. After viewing these scenes, spectators might feel encouraged to examine their own lives - and their own consciences - to see where they, too, might need to confess or repent. Montiel Contreras confirms that at least for the Jesuit school drama, this was definitely the case: "El teatro jesuita, como instrumento pedagógico y social, fue la forma idónea para que los casos de conciencia de los protagonistas en escena fueran también formulados en el foro interno de un amplio auditorio" (Montiel Contreras 69). As I noted in Conscience on Stage:

There are, in fact, numerous accounts suggesting that after witnessing a performance of one of these plays, the audience members did just that [i.e. examined their own consciences or resolved to change their lives]. The [Jesuit] dramatist Acevedo reported that after a performance of Euripus in Córdoba, many members of the audience swarmed to the confessional: 'no faltó quien tocado del desastrado fin de Euripo ... acudiese a la confesión' [...] Likewise, after a performance of his play Metanea (or De penitentia) in the same colegio on 1 September 1561, Acevedo wrote a letter reporting that the actors performed better as a result of having gone to confession and that the audience, in turn, was inspired to confess.

KALLENDORF 2007: 29

There is a risk in our postmodern secular era (when sacramental confession is not a weekly, monthly or even annual ritual for most playgoers) that we might lose these casuistical resonances which are no longer so culturally relevant for our times as they were for their original authors and audiences. By recapturing these allusions and recovering their original sacramental context, we hope to restore to them also their power to move our hearts. And perhaps even to stir our consciences....

\section{Works Cited}

Angulo Egea, María. Luciano Francisco Comella (1751-1812). Otra cara del teatro de la Ilustración. Alicante: Universidad de Alicante, 2006.

Antonucci, Fausta. "La materia caballeresca en el primer Lope de Vega." XXVIII Jornadas de Teatro Clásico (Almagro, 2005): 59-77. 
Bernardo de Quirós Mateo, José Antonio. Teatro y actividades afines en Ávila (Siglos XVII, XVIII y XIX). Ph.D. dissertation, Universidad Nacional de Educación a Distancia (Madrid), 1993-94.

Bonifacio, Juan. Actio quae inscribitur Nepotiana Gometius (1572). Códice de Villagarcía, Real Academia de la Historia (Madrid), no. 13, fols. 129r-138r.

Bonifacio, Juan. Tragedia Nabalis. In El Códice de Villagarcía del P.Juan Bonifacio: Teatro clásico del siglo XVI. Ed. C. González Gutiérrez. Madrid: Universidad Nacional de Educación a Distancia, 2001a: 347-406.

Bonifacio, Juan. Triumphus Circuncisionis. Códice de Villagarcía, Real Academia de la Historia (Madrid), no. 4, fols. 24v-31.

Bonifacio, Juan. Triumphus Eucharistiae. In El Códice de Villagarcía delP.Juan Bonifacio: Teatro clásico del siglo XVI. Ed. C. González Gutiérrez. Madrid: Universidad Nacional de Educación a Distancia, 2001b: 6o9-652.

Brontë, Charlotte. Jane Eyre: An Autobiography. London: Service \& Paton, 1897. Digital edition transcribed by David Price for Project Gutenberg. https://www.gutenberg .org/files/126o/126o-h/126o-h.htm.

Calderón de la Barca, Pedro. El año santo de Roma (loa). Digital version based on the critical edition of Pedro Calderón de la Barca, Lo que va del hombre a Dios. Eds. Ignacio Arellano and Ángel L. Cilveti. Pamplona/Kassel: Universidad de Navarra/Reichenberger, 1995. http://www.cervantesvirtual.com/obra/el-ano-santo -de-roma--o/.

Calderón de la Barca, Pedro. La exaltación de la Cruz. In Primera parte de Comedias escogidas de los mejores de España. Madrid: Domingo García Morras, 1652: 62r-85v.

Chouza-Calo, María del Pilar. "Sangre y llanto: escenificación de la violencia en El marqués de Mantua de Lope de Vega." eHumanista 44 (2020): 1-15.

Comella, Luciano Francisco. El dichoso arrepentimiento (179o). N.p.: n.p., n.d. Depósito Académico Digital, Universidad de Navarra. https://dadun.unav.edu/ handle/10171/28353.

Del Río Parra, Elena. Cartografías de la conciencia española en la Edad de Oro. Mexico City: Fondo de Cultura Económica, 2008.

Derrida, Jacques. "Structure, Sign and Play in the Discourse of the Human Sciences." Writing and Difference. Trans. Alan Bass. Chicago: University of Chicago Press, 1978: 278-94.

Douay-Rheims Bible. http://www.biblehub.com/drb.

Espín Templado, María Pilar. “Disposición temática en 'El marqués de Mantua,' tragicomedia de Lope de Vega." Epos: Revista de Filología 5 (1989): 165-82.

González Gutiérrez, Cayo. "El P. Juan Bonifacio, dramaturgo." Epos: Revista de Filología 10 (1999): 467-92.

González Gutiérrez, Cayo. El teatro escolar de los jesuitas (1555-1640) (Su influencia en el Teatro del Siglo de Oro). Oviedo: Universidad de Oviedo, 1997. 
González Gutiérrez, Cayo. "El Teatro en los Colegios de Jesuitas y su influencia en la Comedia nacional del siglo XVII." Entemu: Revista de la Universidad Nacional de Educación a Distancia 3 (1991): 87-110.

Kallendorf, Hilaire. Ambiguous Antidotes: Virtue as Vaccine for Vice in Early Modern Spain. Toronto: University of Toronto Press, 2017.

Kallendorf, Hilaire. Conscience on Stage: The Comedia as Casuistry in Early Modern Spain. Toronto: University of Toronto Press, 2007.

Kallendorf, Hilaire. "The Diabolical Adventures of Don Quixote, or Self-Exorcism and the Rise of the Novel." Renaissance Quarterly 54.1 (2002): 193-223.

Kallendorf, Hilaire. "Dressing a Salad, Clothing with Virtue; or, Is One Language More Righteous than Another?" St Francis Xavier and the Jesuit Missionary Enterprise: Assimilations between Cultures/San Francisco Javier y la empresa misionera jesuita. Asimilaciones entre culturas. Eds. Ignacio Arellano and Carlos Mata Induráin. Pamplona: Servicio de Publicaciones de la Universidad de Navarra, 2012: 113-23. [BIADIg, Biblioteca Áurea Digital-Publicaciones Digitales del GRIso] http://www .unav.es/publicacion/sfj-navarro-universal/publicacion.

Kallendorf, Hilaire. Sins of the Fathers: Moral Economies in Early Modern Spain. Toronto: University of Toronto Press, 2013.

Kallendorf, Hilaire. "Splitting Hairs or Finding Threads: The Labyrinth as Metaphor for Moral Dilemma in the Comedia." Docta Y SABIA ATENEA. Studia in honorem Prof. Lía Schwartz. Eds. Sagrario López Poza et al. A Coruña: Universidade da Coruña (2019): 339-58.

Kamen, Henry. "Religion." A Companion to the Spanish Renaissance. Ed. Hilaire Kallendorf. Leiden: Brill, 2019: 186-204.

Lope de Vega, Félix. El marqués de Mantua. Ed. Felipe B. Pedraza Jiménez. Comedias, Parte XII. Tomo II. Ed. Prolope. Coord. José Enrique Laplana Gil. Madrid: Gredos, 2013: 3-153.

Montiel Contreras, Carlos-Urani. "Competencia entre compañías: la escenificación de Nabal Carmelo por comediógrafos y jesuitas.” TeatrEsco 5 (2012-13): 57-72.

Oleza, Joan. "De Montaigne a Lope: distintos resultados de una misma decisión." Revista de Literatura 71.141 (2009): 39-56.

Pedraza Jiménez, Felipe B. "Personas reales y justicia poética: Lope, Guillén de Castro, Rojas Zorrilla." Lectura y Signo 2 (2007): 129-56.

Pedraza Jiménez, Felipe B. "Prólogo" a El marqués de Mantua. In Lope de Vega, Comedias, Parte XII. Tomo II. Ed. Prolope. Coord. José Enrique Laplana Gil. Madrid: Gredos, 2013: 3-23.

Pedraza Jiménez, Felipe B. Sexo, poder y justicia en la comedia española: cuatro calas. Vigo: Editorial Academia del Hispanismo, 2007b.

Pérez García, Norberto. "Lope de Vega, Jerónimo Cáncer y las dramatizaciones áureas de los romances del marqués de Mantua." Cuadernos para Investigación de la Literatura Hispánica 26 (2001): 189-2006. 
Rosselló Castillo, Luisa. "Algunas ideas sobre la monarquía en dos comedias de Lope de Vega con el príncipe enamorado." Pensamiento y literatura en los inicios de la modernidad. Ed. Jaume Garau. New York: Instituto de Estudios Auriseculares, 2017: 147-89.

Ruiz del Vizo, Hortensia. El Marqués de Mantua (Simbolismo y Evangelio en Lope de Vega). Miami: Universal, 1971.

Sánchez Jiménez, Antonio. Review of Hilaire Kallendorf, Sins of the Fathers: Moral Economies in Early Modern Spain. RILCE 32.2 (2016): 577-83.

Stegner, Paul D. “Try what repentance can': Hamlet, Confession, and the Extraction of Interiority." Confession and Memory in Early Modern English Literature. London: Palgrave Macmillan, 2016: 105-29.

Ximénez, Francisco. Diálogo hecho en Sevilla ... a la venida del padre visitador a las Escuelas.... a la venida del padre visitador a las Escuelas. La Tragedia de San Hermenegildo y otras obras del teatro español de colegio. Ed. Julio Alonso Asenjo. Valencia: Universidad Nacional de Educación a Distancia, Universidad de Sevilla, and Universitat de València, 1995: 1:362-422. 
978-90-04-50682-4

Downloaded from Brill.come4/26/2023 03:30:55PM via free access 


\section{Index}

Albertus Magnus 158-159, 163-164, 174

Alemán, Mateo

Gúzman de Alfarache $12,14,5^{6-73}, 79$, 85-87, 89-9o

Alfonso Fernández de Madrigal,

Tostado 23, 26, 28

Confessional del Tostado $\quad 26,28$

Amadís de Gaula 45

Amadís de Grecia $\quad 68,74$

Aquinas, Thomas $3,105,130$ n. 21, 158 n. 2, $159,163,166,170-171,173-174$

Aristotle 3, 130 n. 21, 151, 159, 163-165, 168, 170,174

Aristotelian 1-2, 4, 34

Nicomachean Ethics 34

Astraea, goddess $185^{-186}$

Augustine of Hippo 130 n. 21

Augustinian 34

City of God $\quad 3,30$

Auvergne, Guillaume d'

De fide et legibus $\quad$ 161-162, 172

Avellaneda, Alonso Fernández de

Quijote de Avellaneda $\quad 5^{8}$

Avianus, Flavius $\quad 67-68$

Azpilcueta, Martín de 10,64 n. 10, 66 n. 12, 73

Manual de confessores y penitentes 122

$$
\text { n. } 12,123,130,132
$$

Badius Ascensius, Jodocus

Stultiferae Naves 32

Bakhtin, Mikhail 93, 106

Barçalo, Guillermo

Tragedia de divite epulone 192

Bartoli, Daniel 58 n. 4, 73

Belianís de Grecia 45

Benavente Motolinía, Toribio de $\quad 156$

Biagioli, Mario 109

Biel, Fadrique (de Basilea) 32

Boccaccio, Giovanni $\quad$ 148-149, 153, 155

Claris mulieribus $\quad 28,38$

Boethius 106

Bonifacio, Juan

Tragedia Nabalis $\quad 183$
Triumphus Circuncisionis $\quad$ 178, 183-185, 188-189, 199

Triumphus Eucharistiae $\quad 185$

Borromeo, Carlo 183

Brant, Sebastian

Narrenschiff $\quad 3^{1-32}$

Brontë, Charlotte

Jane Eyre 196, 199

Calderón de la Barca, Pedro

El año santo de Roma 190, 192, 199

La exaltación de la Cruz 192

Calderón, Rodrigo 92

Calila e Dimna 6

Carlos, Prince 180-181, 200

Caro Baroja, Julio $\quad$ 9-10, 14, 79 n. 4, 9o, 127, 132

Castillo de Bobadilla, Jerónimo

Política de corregidores 114-115, 118-119, 132

Castillo Solórzano, Alonso de 13

Huerta de Valencia 148, 153

Catalina de Saboya $178 \mathrm{n} .3$

Celestina Comentada 23

Cervantes, Miguel de 86 n. 12, 87, 92, 98

Don Quijote $\quad 6,13-16,42$ n. 2, 43-44, $53-54,58,86,87$ n. $13,89-90$

La gran sultana 87 n. 13

Novelas ejemplares $123,125,132$

Pedro de Urdemalas 87 n.13, 92

Chaucer, Geoffrey

Canterbury Tales 153 n. 25

Cicero, Marcus Tullius $2-3,9,15,41-42$, 106

Ciceronian 4, 9-10

Cisneros, Francisco Jiménez de, Cardinal $\quad 17,33^{-} 35$

Complutensian Polyglot Bible 34

Comella, Luciano Francisco

El dichoso arrepentimiento 194, 196, 198-199

Corpus Iuris Canonici 20

Cota, Rodrigo 17

Covarrubias, Sebastián de $\quad 66,73$ 
Croce, Luigi Annibale della 99

Cuarta parte de Florisel de Niquea n. 14

Daniel, Gabriel 58 n. 4, 65 n. 11, 73

David, King $\quad 184,199$

Derrida, Jacques $\quad$ 183-184, 199

Díaz, Juan $68,70,74$

Dolce, Lodovico $\quad 98-99$

Domingo de Santo Tomás 156

Donneau de Visé, Jean 107

Don Quijote 40, 42-43, 53-54, 194

El Sendebar $\quad 6,125$

Erasmus of Rotterdam 104

Escobar y Mendoza, Antonio 66 n. 12, 73, 120 n. 10

Felipe II 94, 180

Fernández de Madrigal, Alfonso Tostado

Confessional del Tostado $\quad 20,22$

Tostado 20-22, 38

Tratado de cómo al hombre es necesario

amar 20,38

Ferraris, Lucio 158 n. 1, 175

Furió Ceriol, Fadrique

El consejo y consejeros del Príncipe

$114-115,12 \mathrm{O}-121,128,129$ n. 18,13 o n. 22, 133

Galilei, Galileo 109

Gálvez, Ignacio

Colección Gálvez $\quad 178$ n. 3

García, Francisco 64 n. 10

García Gual, Carlos 98

Ghislain de Busbecq, Ogier 99

Giolito de Ferrari, Gabriel $\quad$ 94, 98-99

Gonzalo de Alba

Libro sinodal 19-21, 24, 26, 28, 37

Guevara, Antonio de 101

Relox de príncipes 115 n. 4, 117 ก. 6

Heliodorus 95, 97-98

Henri IV 179

Hermagoras 106

Horace (Quintus Horatius Flaccus) 66, 68-71

Hurtado de Mendoza, Diego 99
Innocent IV 172,175

Jeremiah

Book of Lamentations 30

John of the Cross, Saint $\quad 183$

Jolles, André 96

Juan Manuel

El conde Lucanor 6

Lacan, Jacques $34 \mathrm{n} .9$

Lactantius 171

La pícara Justina $\quad 79,84,86,89,92$

Las Casas, Bartolomé de

Apologética historia sumaria $\quad$ 156-175

Historia de las Indias $\quad 5,13$

Lazarillo de Tormes $\quad$ 11-12, 39-45, 53-55

Locher, Jakob

Stultifera Navis 32

Lope de Vega, Felix $\quad$ 98, 100-101

Arte nuevo 1

El Marqués de Mantua 178-179, 181, 197-201

López de Alvarado

Breve Compendio de Confessión 80, 91

Lopez de Úbeda, Francisco 75

La Pícara Justina 12, 75-93

Luján de Sayavedra, Mateo

Segunda parte de la vida del pícaro

Guzmán de Alfarache $\quad$ 56, 58-59, 63

n. $9,64,67,69$ n. 14, 71, 73

Luna, Beatriz de 94

Machiavelli, Niccolò $\quad 7,12,126$

Madame de La Fayette 107

Mariana, Juan de

De rege et regis institutione 179

Martí, Juan

Luján $\quad 5^{8}$ n. 3, 67

Medina, Bartolomé de $\quad 4,6-7,11$

Breve instrucción $\quad 7,122,124,130,133$

Mena, Juan de 17

Mendes Nasi, Gracia 94

Mexía, Pedro 108

Micas, Juan 94

Molière 9

Molina, Luis de 4, 9, 16

Montaigne, Michel de 197, 200

Most, Glenn 100 
Nasi, Joseph 94

Nebrija, Antonio de $\quad$ 17, 33, 35, 37

Diccionario de derecho civil 35

Núñez de Reinoso, Alonso 93-95, 97-101, 103, 107-108

Historia de los amores de Clareo y Florisea 12

Ortega y Gasset, José $\quad$ 8, 16, 131, 133

Osuna, Francisco de

Norte de los estados 121

Ovid 96, 108

Páez de Ribera, Ruy $\quad 68,70,74$

Panofsky, Erwin $30-31,38$

Pascal, Blaise 65 n. 12, 73, 127

Lettres provinciales $\quad 1,7,9,16,81$

Peñafort, Ramón de 97

Pereira, Gómez 4

Petrarca, Francesco

Remedia 155

Petrus Alphonsi, = Moshé Sefardì

Disciplina Clericalis 6

Plato 100, 130 n. 21

Pliny 41-42

Polanco, Juan

Directorium breve 7

Proaza, Alonso de 17 n. 1, 33 n. 8, 34

Quevedo, Francisco de

El Buscón $\quad 86,92$

Quintilian 106

Rao, Cesare

Invettive, orationi, discorsi $\quad$ 142, 155

Ribadeneira, Pedro de

Tratado de la religion y las virtudes $114-115,117-118,120,128-13$ o, 134
Ribadeneyra, Pedro de 65 n. 11, 74

Roa, Fernando de 19 n. 3, 33, 37

Robertson, D.W. 106

Rojas, Fernando de $\quad 17-38$

LaCelestina 11

Rose, Constance Hubbard 94

Sánchez, Francisco 4, 9

Second Book of Homilies 192

Seneca 104

Sepúlveda, Juan Ginés de $\quad$ 170-172, 174-175

Setanti, Joaquín

Centellas de varios conceptos $\quad 127$

Siete Partidas 24

Silva, Feliciano de $\quad 68-71,74$

Soto, Hernando de $\quad 4,56,70$ n. 17

Suárez de Figueroa, Cristóbal 13

La constante Amarilis 154-155

El pasajero 141, 142 n. 11, 144-145, 152,

$154^{-155}$

Tatius, Achilles $\quad$ 98-100, 102-103

Timoneda, Juan de El sobremesa y alivio de caminantes 155

Toledo, Francisco de 123 n. 14, 134 Instrucción de sacerdotes 7

Tostado 20, 32-33, 36, 38

Tratado de cómo al hombre es necesario amar 38

Valdés, Luis de 67 n.13, 70 n. 15

Valla, Lorenzo 35

Vitoria, Francisco de $\quad 4-5$

Vives, Juan Luis 10

Voltaire 93

Ximénez, Francisco

Diálogo hecho en Sevilla 178, 201 